UNIVERSIDADE DE SÃo PAULO

Museu de ARqueologia e Etnologia

Programa de Pós-Graduação em Arqueologia

AdRIANA MEINKING GUIMARÃES

\title{
Aproveitamento Turístico do PATRIMÔNIO ARQUeológico do MunicíPIO de IRANDUBA, AMAZONAS.
}




\section{Aproveitamento Turístico do Patrimônio Arqueológico do MunicíPIO de IRANDUBA, Amazonas.}

Tese apresentada ao Programa de PósGraduação em Arqueologia do Museu de Arqueologia e Etnologia da Universidade de São Paulo.

Área de Concentração: Arqueologia.

Orientação: Prof. Dr. Eduardo Góes Neves.

Linha de pesquisa: 3 - Gestão do Patrimônio Arqueológico.

Versão corrigida(*)

(*) A versão original encontra-se disponível no MAE/USP. 
GUIMARÃES, Adriana Meinking. Aproveitamento Turístico do Patrimônio Arqueológico do Município de Iranduba, Amazonas. Tese apresentada ao Programa de Pós-Graduação em Arqueologia do Museu de Arqueologia e Etnologia da Universidade de São Paulo para obtenção do título de doutora em Arqueologia.

Aprovada em:

Banca examinadora:

Prof. Dr. Eduardo Góes Neves. Instituição: MAE/USP

Assinatura:

Prof. Dr. Camilo de Melo Vasconcellos. Instituição: MAE/USP

Assinatura:

Prof. Dra. Rosângela Custódio Cortez Thomaz. Instituição: UNESP

Assinatura:

Prof. Dra. Márcia Bezerra de Almeida. Instituição: UFPA

Assinatura:

Prof. Dra. Camila Moraes Wichers. Instituição: Zanettini Arqueologia

Assinatura: 
"Somos nós que fazemos a vida, como der ou puder ou quiser..."

Eterno Aprendiz Gonzaguinha 


\section{AgRADECIMENTOS}

Ao meu marido Gustavo, pelo amor de mais de uma década, pela paciência nestes cinco anos de pesquisa, pelos mapas, pelos desenhos...

À minha família, por tudo! Aos meus sogros, por tudo! À minha irmã, um agradecimento especial, pela ajuda com a revisão de tantas páginas... e com as traduções!

Ao meu orientador, pela oportunidade e pelo aprendizado.

Ao CNPQ, pela bolsa concedida.

Aos funcionários da Secretaria Acadêmica do MAE, pela ajuda sempre eficiente.

Aos funcionários da Biblioteca do MAE, pela simpatia e presteza.

Aos colegas do PAC, pelos momentos compartilhados. Especialmente, a Kazuo, pelo envio do arquivo com centenas de sítios plotados por toda Amazônia.

A Bruna Rocha e a João Saldanha, pelo compartilhamento das suas informações de pesquisas no rio Tapajós e no Amapá, respectivamente.

A "seu" Nego e sua família, por todas as vezes que me receberam em sua casa no Lago do Limão.

A "seu" Milton e sua família também por me receberem em sua casa e por me ajudarem em tudo que precisei no período do curso no Lago do Limão.

A Leandro, meu orientando da UEA, pela ajuda durante o curso e pelos dados da sua pesquisa.

Aos meus alunos no curso do Lago do Limão.

Aos meus alunos na UEA, pelas palavras de apoio.

A Helena Lima pelo convite para o campo de Silves e a ela e a Gisele Felipe pela tentativa de testar a proposta de Turismo Científico naquele local.

A André Bazanella, pela vontade de fazer!

Ao fotógrafo Max Cohen que, mesmo sem me conhecer, me cedeu algumas de suas maravilhosas fotografias para ilustrar essa tese.

Aos meus amigos por alegrarem minha vida!

Enfim, a todos que participaram, direta ou indiretamente, na produção desse trabalho, meu muito obrigada!

Como não podia deixar de ser: a Luna e a Gaia, minhas filhas de quatro patas, pela companhia em casa nas longas horas de estudo e por todo amor incondicional! 


\section{APRESENTAÇÃo}

Esta tese constitui-se no resultado de pesquisa realizada para obtenção do grau de doutora em Arqueologia pela Universidade de São Paulo.

Trata-se de um estudo cujo objetivo principal foi demonstrar a viabilidade do aproveitamento turístico do patrimônio arqueológico no município de Iranduba. Para isso, buscou-se, especificamente, apresentar propostas de uso sustentável de locais patrimoniais com o desenvolvimento de uma estrutura interpretativa dessa herança cultural para o uso no turismo. A tese está estruturada em quatro capítulos, conforme descrição abaixo:

O primeiro capítulo dedica-se à apresentação das problemáticas que permeiam a relação do turismo com o patrimônio arqueológico brasileiro. Para isso, buscou-se apresentar e discutir, ao longo do texto, conceitos considerados importantes para a compreensão deste trabalho tanto por leitores das duas áreas envolvidas, quanto por leitores de áreas afins.

O segundo capítulo aborda o Turismo Arqueológico ou Arqueoturismo. Não foram feitas grandes incursões nos exemplos nacionais ou internacionais, nem análises a partir dos mesmos, porque se julgou que não seria fundamental para o encaminhamento deste trabalho. Optou-se por focar a questão do planejamento dos produtos arqueoturísticos e sintetizar os materiais nacionais e internacionais disponíveis que abordassem Melhores Práticas para atividade ou, de forma mais abrangente, Turismo Cultural, Ecoturismo, planejamento turístico etc. Além disso, fez-se um esforço em reunir princípios norteadores que devem ser considerados por todos os envolvidos com o Turismo Arqueológico. $\mathrm{Na}$ última parte deste capítulo, apresentou-se a Interpretação do Patrimônio e destacou-se a importância do seu uso no planejamento da comunicação com os visitantes de locais com patrimônio culturais.

A área de pesquisa é contextualizada no terceiro capítulo, onde se buscou sintetizar e transmitir as informações disponíveis sobre arqueologia amazônica, de maneira geral, e sobre a arqueologia realizada na Amazônia central, em sua especificidade. Tentou-se fugir de abordagens puramente técnicas e construir um cenário "vivo" que pudesse ser 
visualizado por não-arqueólogos. Ainda neste capítulo, expõe-se o potencial percebido para o desenvolvimento do Turismo Arqueológico na região amazônica e, mais detalhadamente, no estado do Amazonas, tendo como estudo de caso o município de Iranduba.

No quarto capítulo apresentam-se as propostas de uso sustentável do patrimônio arqueológico formuladas para o município de Iranduba. As propostas baseiam-se no desenvolvimento de uma estrutura interpretativa da herança cultural/arqueológica local, para o uso no turismo. Este último capítulo detalha os encaminhamentos dados a cada uma das propostas, o processo para viabilizá-las e as considerações sobre cada uma das vivências. O capítulo em questão é concluído com observações em relação à inserção de produtos arqueoturísticos no cenário turístico atual do município de Iranduba.

Finalmente, a tese é encerrada com algumas considerações sobre a experiência vivenciada durante o encaminhamento deste trabalho. 


\section{RESUMO}

\section{GUIMARÃES, Adriana Meinking. Aproveitamento Turístico do Patrimônio}

Arqueológico do Município de Iranduba, Amazonas. 2012. 239 f. Tese (doutorado). São Paulo, SP: Museu de Arqueologia e Etnologia/Universidade de São Paulo. 2012.

A arqueologia brasileira, bem como o próprio patrimônio arqueológico, ainda é pouco conhecida de grande parte da sociedade nacional. Esta tese defende o Turismo Arqueológico como uma atividade capaz de difundir essa ciência e, principalmente, capaz de proteger o patrimônio arqueológico. Essa defesa baseia-se (i) em discussões sobre a vulnerabilidade desse patrimônio devido, em parte, aos próprios estudos arqueológicos que estão sendo realizados no país por conta de grandes obras (gasodutos, polidutos, estradas, hidrelétricas etc.); (ii) no detalhamento conceitual de aspectos teóricos e práticos do turismo; (iii) na síntese de princípios de melhores práticas que podem auxiliar na implantação e desenvolvimento de projetos de Turismo Arqueológico dentro dos preceitos de sustentabilidade; (iv) na ênfase da importância da Interpretação Patrimonial para o planejamento da comunicação com os visitantes de locais com patrimônio culturais. A tese apresenta uma gama de atrativos arqueoturísticos diferentes entre si, mas pensados em complementariedade, destinados ao município de Iranduba, estado do Amazonas (Amazônia central brasileira). As propostas apresentadas mostram que é viável aproveitar turisticamente o patrimônio arqueológico local, embora lhe falte monumentalidade, e podem auxiliar no desenvolvimento de propostas similares país a fora.

Palavras-chave: Arqueologia, Turismo, Interpretação Patrimonial, Gestão do Patrimônio Arqueológico. 


\section{ABSTRACT}

GUIMARÃES, Adriana Meinking. The use of Archeological Heritage Tourism in the Municipality of Iranduba, Amazonas. 2012. 239 p. Thesis (PhD). São Paulo, SP: Museu de Arqueologia e Etnologia/Universidade de São Paulo. 2012.

Brazilian archeology, along with its archeological heritage, is still little known to the great majority of the Brazilian society. This thesis maintains that Archeological Tourism is an activity not only able to disseminate the knowledge of archeological science but also and mainly to protect the archeological heritage. It is based on (i) discussions about this heritage's vulnerability partly due to archeological studies being carried out in Brazil as a result of the construction of great infrastructure projects (e.g. oil and gas pipelines, roads, hydroelectric dams and so forth); the conceptual exposition of theoretical and practical aspects of Tourism; (iii) the summary of Best Practice principles that might help to develop and implement projects in Archeological Tourism following the rules of sustainability. (iv) the emphasis on the importance of Heritage Interpretation for planning the communication with visitors to cultural heritage sites. This thesis proposes a series of attractive archeological tourism products for the municipality of Iranduba, in the state of Amazonas (Brazilian Central Amazon), that although diverse, are meant to complement each other in their purposes and uses. The presented proposals show the feasibility of using the local archeological heritage touristically, even if this lacks monumentality, helping with the development of similar proposals around the country.

Keywords: Archaeology, Tourism, Heritage Interpretation, Archaeological Heritage Management. 


\section{LISTA DE ILUSTRAÇÕES}

\section{Capítulo I}

Ilustração I.1: Levantamento topográfico (FotografiA: Val de Moraes/ Acervo PAC).

Ilustração I.2: Imagens de procedimentos em campo/registro (FotOGRAFIAS: Val de Moraes. Acervo PAC).

Ilustração I.3: Exemplo de embalagem para recolhimento de sedimentos e vestígios (Fotografia: Val de Moraes. Acervo PAC).

Ilustração I.4: Imagens de procedimentos em campo/ peneiramento (FOTOGRAFIAS: Val de Moraes. Acervo PAC).

Ilustração I.5: $\quad$ Perfil de escavação em sítio de Terra Preta (FotografiA: Val de Moraes. Acervo PAC).

Ilustração I.6: Infraestrutura existente no Parque Nacional da Serra da Capivara, Piauí (FotogRAFIAS: Adriana Guimarães, 2006).

\section{Capítulo II}

Ilustração II.1: Serra da Capivara. São Raimundo Nonato, Piauí (FotografIAS: Adriana Guimarães, 2006).

Ilustração II.2: Costão do Santinho. Florianópolis, Santa Catarina (FotografiAs: Adriana Guimarães, 2007).

Ilustração II.3: Panfleto (Fundação Garcia D’Ávila) e Castelo Garcia D’Ávila, Praia do Forte, BA (FotografiAs: Adriana Guimarães).

Ilustração II.4: Esquema dos Macro Processos da Gestão do Patrimônio Arqueológico FONTE: PARDI, 2002: 21.

Ilustração II.5: Augusta Raurica. Teatro Romano e sua ilustração e interpretação em um painel, no detalhe (Fotografias: Gustavo Accacio e Adriana Guimarães, 2011).

Ilustração II.6: $\quad$ Augusta Raurica. Folder promocional: capa e páginas internas ilustradas mostrando o festival romano, pessoas caracterizadas e o interior da Roman House.

Ilustração II.7: $\quad$ Augusta Raurica. Painel da trilha interpretativa, com perguntas que serão respondidas na próxima placa (FotografIAS: Adriana Guimarães, 2011). 
Ilustração II.8. Roma. Complexo Arqueológico Foro Romano e Colosseo (FotOgRAfIAS: Adriana Guimarães, 2011). Capa do mapa do áudio guia e parte interna onde os pontos de interesse estão destacados.

llustração II.9: Zona Arqueológica de Palenque. Sistema de trilhas com as placas interpretativas destacadas nas imagens e no detalhe (FotOGRAFIAS: Gustavo Accacio, 2009).

Ilustração II.10: Xcaret. Encenações diurnas. Atores com vestimentas baseadas na iconografia Maia (FotografiAs: Adriana Guimarães, 2009).

Ilustração II.11: Xcaret. México Espectacular. Cenas do início do jogo com a bola de borracha Pok ta' pok (FotografiAs: Gustavo Accacio, 2009).

Ilustração II.12: Museu d'Historia de la Ciutat. Plaça del Rei. Barcelona, ES (FotOGRAFIAS: Adriana Guimarães, 2012).

Ilustração II.13: Mecanismo de Comunicação com os Visitantes - Ciclo da Visitação (FONTE: traduzido e adaptado de Fl, s/d).

\section{Capítulo III}

Ilustração III.1: Mapa com a localização de sítios arqueológicos na Amazônia brasileira. Sítios na Amazônia central e porção SO: dados compilados por Eduardo Tamanaha com base nos dados do PAC e em informações cedidas por pesquisadores ligados ao PAC; sítios na região do Tapajós, PA: informações cedidas pela pesquisadora Bruna Rocha; sítios no Amapá e NE do Pará: informações cedidas pelo arqueólogo João Saldanha (ARTE: Gustavo Accacio, 2012).

Ilustração III.2: Encontro das águas dos rios Solimões e Negro (FotografiA: Eduardo Neves).

Ilustração III.3: $\quad$ Rio Negro (FotografiA: Adriana Guimarães, 2006).

Ilustração III.4: Rio Tapajós (FotografIAS: Adriana Guimarães, 2006).

Ilustração III.5: Sítio D. Stella, Iranduba, AM. Escavação em areal (FotogRAFIAS: Acervo PAC. 2006).

llustração III.6: Terra Preta. Escavações no Sítio Laguinho (Fotografia: Acervo PAC) e escavação no Sítio Hatahara em Iranduba, AM. (FotografiA: Acervo PAC) e sítio de Terra Preta em Itacoatiara (FotografiA: Adriana Guimarães).

Ilustração III.7: Montículos. Sítio Laguinho (FotografiAs: Acervo PAC).

Ilustração III.8: Sambaqui do Bacanga e vestígios típicos, Maranhão (FotogRAFIAS: Adriana Guimarães, 2006). 
Ilustração III.9: Cachimbo, Acrelândia (FotografiAs: Denise Schaan (menor) e Diego Gurgel (maior). FONTE: SCHAAN et al., 2010).

Ilustração III.10: Fabricação de farinha de mandioca, processo de torra. Lago do Limão, Iranduba, AM. (FotografiA: Adriana Guimarães, 2006).

Ilustração III.11: Cauixi preso em um galho de árvore depois da cheia e seca do rio. Silves, AM. (FotografiA: Adriana Guimarães, 2010).

Ilustração III.12: Costela de Tambaqui assada na brasa, prato típico da comida amazonense (à esquerda) e boto cor de rosa (FotOgRAFIAS: Adriana Guimarães).

Ilustração III.13: Objetos sob a guarda de comunitários no Amazonas (FotografiAs: Adriana Guimarães, 2007).

Ilustração III.14: Ponte sobre o rio Negro (Fotografia: Max Cohen).

Ilustração III.15: Sítio Hatahara (FotografIA: Adriana Guimarães, 2006).

Ilustração III.16: Vista do sítio arqueológico Laguinho (FotogRAFIA: Acervo PAC, 2007).

Ilustração III.17: Praia de Paricatuba (FotografiA: Max Cohen).

Ilustração III.18: Prédio de Paricatuba na época em que foi construído (Fotografia digitalizada, cedida pelos professores da Fundação Bradesco. FONTE: desconhecida).

Ilustração III.19: Situação atual da fachada do prédio hoje (FotOGRAFIA: Max Cohen).

Ilustração III.20: Situação atual do interior do prédio (FotOGRAFIAS: Max Cohen)

Ilustração III.21: Funcionamento do Instituto Afonso Penna. (Fotografias digitalizadas, cedidas pelos professores da Fundação Bradesco. FonTE: desconhecida).

Ilustração III.22: Situação de abandono do interior da "Ruína de Paricatuba" (FotogRAFIAS: Adriana Guimarães, 2011).

Ilustração III.23: Vista do lago do Limão (FotogRAFIA: Adriana Guimarães, 2010).

\section{Capítulo IV}

Ilustração IV.1: Localização e cenário atual dos locais trabalhados (ARTE: Gustavo Accacio).

Ilustração IV.2: $\quad$ Logo para o Museu de Sítio Arqueológico Hatahara (ARTE: Júlio Miqueline. Fonte: Verde Volta ASs. e Rec. Amb. LTdA, 2009).

Ilustração IV.3: Mapa de implantação do Museu com a localização do Centro de Acolhimento, do Centro Técnico e da Trilha Exploratória (FONTE: VerdE 
Volta Ass. e Rec. Amb. LtdA., 2009).

llustração IV.4: Perspectiva artística de uma trincheira reaberta, com acesso ao público e proteção contra intempéries (FONTE: Verde VoltA AsS. E REC. AMB. LTDA., 2009).

Ilustração IV.5: Perspectiva artística da cobertura das áreas abertas (FONTE: VERDE VolTA Ass. E ReC. AMB. LTDA., 2009).

Ilustração IV.6: Perspectiva artística da reabertura de uma área escavada em 2006, conhecida como área das urnas (Fonte: Verde Volta Ass. e ReC. AMB. LTDA., 2009).

llustração IV.7: Perspectiva artística dos pontos do percurso (FonTE: Verde VoltA Ass. E ReC. AmB. LTDA., 2009).

Ilustração IV.8: Perspectiva artística dos painéis verticais (FonTE: Verde VoltA AsS. E ReC. AMB. LTDA., 2009).

Ilustração IV.9: Perspectiva artística do Guia da Trilha (Fonte: Verde Volta Ass. e ReC. AmB. LTDA., 2009).

Ilustração IV.10: Logo para a Vila de Paricatuba interpretada (ARTE: Gustavo Accacio).

Ilustração IV.11: Fachada restaurada, placas de sinalização e painel interpretativo (ARTE: Gustavo Accacio).

Ilustração IV.12: Sala expositiva com maquete, reprodução de vídeo, fotografias etc. (ARTE: Gustavo Accacio).

Ilustração IV.13: Exposição de fotografias (ARTE: Gustavo Accacio).

Ilustração IV.14: Espaço com manutenção controlada da situação em que o prédio permaneceu durante anos (ARTE: Gustavo Accacio).

Ilustração IV.15: Coleção sob a guarda de comunitário em Paricatuba (FoTOGRAFIA: Adriana Guimarães, 2006).

Ilustração IV.16: Logo para o Centro de Artesanato e Réplicas do Lago do Limão (ARTE: Gustavo Accacio).

Ilustração IV.17: Ilustração artística do funcionamento do Centro de Artesanato e Réplicas no Lago do Limão (ARTE: Gustavo Accacio).

Ilustração IV.18: Vasos comprados em Belém, PA (FotografiA: Adriana Guimarães, 2012).

Ilustração IV.19: Exemplos de réplicas arqueológicas fabricadas em resina, apresentadas pelo Prof. Bruce Bradley, no EAPT Rio Claro, Jul. 2011 (FotografiAs: Adriana Guimarães, 2011). 
Ilustração IV.20: Réplicas variadas expostas no Palacete Provincial em Manaus. Réplicas diversas, Vênus de Lespugue e etiqueta informativa, com dados sobre a réplica (FotogRAFIAS: Adriana Guimarães, 2010).

Ilustração IV.21: Primeira reunião no Lago do Limão, 2008.

Ilustração IV.22: Desenho dos mapas e classificação dos atrativos mais significativos (FotografiA: Leandro Braga, 2010).

Ilustração IV.23: Logo para atividades de Turismo Científico (ARTE: Gustavo Accacio).

Ilustração IV.24: Ilustração artística de participação supervisionada em escavação arqueológica (ARTE: Gustavo Accacio).

Ilustração IV.25: Ilustração artística de visitação turística a escavação arqueológica (ARTE: Gustavo Accacio).

Ilustração IV.26: Layout de um folder turístico promocional do município de Iranduba, caso sejam implantadas as propostas contidas nesta tese (ARTE: Gustavo Accacio).

\section{LISTA DE GRÁFICOS}

\section{Capítulo II}

GrÁfICO II.1: Disponibilidade para pagar por 'entradas em museus', para 'visitar sítios arqueológicos' ou 'fazendo doação para instituições de proteção ao patrimônio'. 


\section{LISTA DE TABELAS}

\section{Capítulo II}

TABELA II.1: $\quad$ Phases of management planning process (FONTE: LIM, 2005: 20).

TABELA II.2: $\quad$ The guiding principles for responsible archaeological tourism (FONTE: AIA, $s / d)$.

TABELA II.3: Linhas mestras para Turismo Arqueológico sustentável (FonTE: A.H.C, 2001).

TABelA II.4: $\quad$ The Six Steps Process (FonTE: LMG, 2003-2006).

TABELA Il.5: Visão para um turismo responsável (FonTE: Resumido de WWF Brasil, 2003).

TABELA II.6: Nível de interesse em realizar viagens arqueoturísticas no Brasil (FonTE: GUIMARÃES, 2011).

TABELA II.7: $\quad$ Nível de interesse em realizar viagens arqueoturísticas no exterior (FONTE: GUIMARÃES, 2011).

TABELA II.8: $\quad$ O que as pessoas gostariam de ver em viagens arqueoturísticas (FonTE: GUIMARÃES, 2011).

\section{Capítulo IV}

TABela IV.1: $\quad$ Roteiro de Comunicação para o Museu de Sítio Arqueológico Hatahara (Fonte: Verde Volta Ass. e Rec. Amb. LtdA., 2009).

TABela IV.2: $\quad$ Pesquisa 'Antes'.

TABela IV.3: $\quad$ Pesquisa 'Depois'.

TABELA IV.4: Verificação Curso dos Guias.

TABELA IV.5: Verificação Treinamento da Equipe de Campo/ Funcionamento dos trabalhos.

TABela IV.6: Verificação Promoção dos Roteiros nos locais onde os cartazes foram afixados.

TABela IV.7: $\quad$ Verificação Promoção dos Rotelros nas pousadas da cidade. 


\section{LISTA DE SIGLAS}

(AIP) Asociación para la Interpretación del Patrimônio

(AMAZONASTUR) Empresa Estadual de Turismo do Amazonas

(CABA) Centro de Arqueologia dos Biomas Amazônicos

(COOPTUR) Cooperativa de Turismo de Silves

(EIA) Estudos de Impacto Ambientais

(EMBRATUR) Instituto Brasileiro de Turismo

(EP) Educação Patrimonial

(EPIA) Estudos Prévios de Impacto Ambiental

(FAPESP) Fundação de Amparo à Pesquisa do Estado de São Paulo

(FIFA) Federação Internacional de Futebol

(FUNAI) Fundação Nacional do Índio

(GPA) Gestão do Patrimônio Arqueológico

(IBAMA) Instituto Brasileiro do Meio Ambiente e dos Recursos Naturais Renováveis

(IBGE) Instituto Brasileiro de Geografia e Estatística

(ICOM) International Council of Museum

(ICOMOS) Conselho Internacional de Monumentos e Sítios

(INCRA) Instituto Nacional de Colonização e Reforma Agrária

(INPE) Instituto Nacional de Pesquisas Espaciais

(IP) Interpretação Patrimonial

(IPHAN) Instituto do Patrimônio Histórico e Artístico Nacional

(LGBT) Lésbicas, gays, bissexuais, travestis, transexuais e trangêneros

(MAE) Museu de Arqueologia e Etnologia

(MTUR) Ministério do Turismo

(OMT) Organização Mundial do Turismo

(ONG) Organização Não-Governamental 
(PAC) Projeto Amazônia Central

(PDF) Portable Document Format

(PNT) Plano Nacional de Turismo

(PROECOTUR) Programa de Apoio ao Ecoturismo e à Sustentabilidade Ambiental do turismo (PRONAPA) Programa Nacional de Pesquisas Arqueológicas

(PRONAPABA) Programa Nacional de Pesquisas Arqueológicas da Bacia Amazônica

(RIMA) Relatório de Impacto Ambiental

(SAB) Sociedade de Arqueologia Brasileira

(SDS) Secretaria de Desenvolvimento Sustentável

(SECT) Secretaria de Ciência e Tecnologia

(TBC) Turismo de Base Comunitária

(UC) Unidades de Conservação

(UEA) Universidade do Amazonas

(UFAM) Universidade Federal do Amazonas

(UFOPA) Universidade Federal do Oeste do Pará

(UNESCO) Organização das Nações Unidas para a Educação, a Ciência e a Cultura (USP) Universidade de São Paulo

(WWF) World Wide Fund for Nature 


\section{LISTA DE ANEXOS}

ANEXo 01 Pôster com o projeto arquitetônico do CABA (Fonte: Acervo PAC).

ANEXO 02 Reportagem 'Diário do Amazonas'. 07 de outubro de 2009.

ANEXo 03 Reportagem 'A Crítica'. 07 de outubro de 2009.

ANEXO 04 Reportagem 'O Globo Online'. 07 de outubro de 2009.

ANEXo 05 Mapa Central do Janauarizinho (Elaboração: Sr. Milton).

ANEXo 06 Mapa Lago do Limão (Elaboração: Sr. Milton).

ANEXO 07 Relatório Gisele Felipe. 


\section{SUMÁRIO}

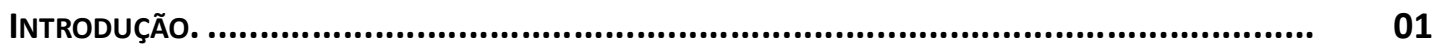

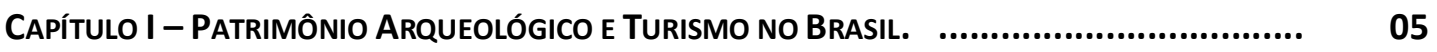

I.1. Aspectos Conceituais e Práticos do TURISMo. 22

CAPÍTULO II - TURISMO ARQUEOLÓGICO. ........................................................... 27

II.1. Analisando as Bases para o Planejamento do Turismo Arqueológico. 36

II.1.1. Espaços Para Diálogos Interdisciplinares e Participativos: O 44 TURISMO NA GESTÃO DO PATRIMÔNIO ARQUEOLÓGICO.

II.2. 'Melhores Práticas' em Turismo Arqueológico - Síntese de literatura 49 ESPECÍFICA E CORRELATA.

II.3. PrincípIos para o Turismo Arqueológico Sustentável.

II. 4. A INTERPRETAÇÃo do PATRIMÔNIO À FAVOR do TURISMO ARQUEOLÓGICO. 66

II.4.1. HISTÓRICO, PRINCÍPIOS E PRÁTICA DA INTERPRETAÇÃO PATRIMONIAL. 69

II.4.2. Como e Por Que elaborar um Planejamento Interpretativo 82 ESTRATÉGICO?

II.5. Propensão do Consumidor Brasileiro para o Turismo Arqueológico. 86

Capítulo III - As Pesquisas arqueológicas e o Potencial para o turismo 95 Arqueológico na Região do Projeto Amazônia Central (PAC). ..................................

$\begin{array}{lr}\text { III. 1. Projeto Amazônia Central. } & 119\end{array}$

III. 2. O Potencial PARA o TURISMo ARQUeOlógICO NA REgIão do PAC. 123

$\begin{array}{ll}\text { III.2.1. O MUNICÍPIO DE IRANDUBA. } & 129\end{array}$

Sítio Arqueológico hatahara. 133

$\begin{array}{ll}\text { Sítio ARQUeOLógICo LagUINHO. } & 135\end{array}$

Sítio ARQueológico Açutuba. 136

$\begin{array}{ll}\text { COMUNIDADE DE PARICATUBA. } & 137\end{array}$

$\begin{array}{ll}\text { COMUNIDADE LAGO DO LIMÃO. } & 146\end{array}$ 
CAPítulo IV - Propostas e Discussões.

IV.I. Propostas para o Aproveitamento TURístico do Patrimônio ARQUEOlógico DE IRANDUBA.

IV. 2. EnCAMINHAMENTO dAs PROPOStas.

155

IV.2.1. Uma FloResta Tocada - MusealizaÇão do Sítio ARQueológico 155 HATAHARA.

A EQUIPE. 156

O Produto final - Anteprojeto de Musealização do Sítio ARQUEOLÓGICO HATAHARA.

CONSIDERAÇÕES SOBRE A ELABORAÇÃO DO ANTEPROJETO DE Musealização do Sítio ARQUeológico Hatahara.

IV.2.2. (Des) CONTINUIDADES: O MESMO ESPAÇO, DifERENTES HISTÓRIAS INTERPRETAÇÃO E SinALIZAÇÃo dA VILA DE PARICATUBA.

O PLANO INTERPRETATIVO.

170

CONSIDERAÇÕES SOBRE A PROPOSTA DE INTERPRETAÇÃO E SINALIZAÇÃO 176 DA VILA DE PARICATUBA.

IV.2.3. InSPIRAÇÃo E LEMBRANÇAS - CENTRO de ARTESANATO E RÉplicas no 177 LAGO DO LIMÃO.

SOUVENIRS.

179

Réplicas em Resina - cOMO MATERIAIS DidÁticos ou COMO 181 SOUVENIRS.

O Encaminhamento da Proposta de CRiação do Centro de ARTESANATO E RÉPLICAS No LAGO dO LIMÃO.

Etapas para a Criação do Centro de Artesanato e Réplicas no LAGO DO LIMÃO.

Formato do Curso Turismo e Arqueologia no Amazonas 188 CONTEÚdo PROgRAMÁtICO.

IMPACTOS ESPERAdOS COM A IMPLANTAÇÃO dO CENTRO DE ARTESANATO E RÉPLICAS NO LAGO do LIMÃO.

Outras Considerações sobre a Proposta de Criação do Centro de ARTESANATO E RÉplicas No LAGO do LiMÃo. 
IV.2.4. A Construção de UM CONHECIMENTO - TURISMO CientífICO.

Encaminhamento da Proposta de Turismo Científico.

ROTEIROS.

Planejamento para a Realização de Atividades de turismo

Científico EM SilVes.

CONSIDERAÇõES SOBRE O ENCAMINHAMENTO DA PROPOSTA DE

214 TURISMO CientífICO.

iV.3. Observações em RelaÇão À Inserção de Produtos Arqueoturísticos no 216 Cenário Turístico Atual do MunicíPIO de IRANDuba.

CONSIDERAÇÕES FINAIS.

224

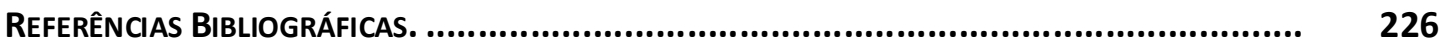

ANEXOS. 


\section{INTRODUÇÃO}

Como proteger $^{1}$ algo que não é conhecido? Esta continua a ser uma grande questão para a arqueologia brasileira, embora essa ciência tenha evoluído muito no Brasil nos últimos anos, com o aumento no número de cursos técnicos, superiores e de pós-graduação oferecidos e, consequentemente, com o aumento do número de profissionais atuantes na área.

A expansão da arqueologia brasileira ocorre, principalmente, desde 2002, com o estabelecimento de procedimentos (nas diversas fases dos EIA) a serem seguidos para a obtenção das licenças ambientais, pela Portaria IPHAN № $230^{2}$. Os trabalhos no âmbito dos EIA proporcionaram um aumento significativo no número de áreas arqueológicas conhecidas, mas não exatamente cientificamente pesquisadas ${ }^{3}$, já que o ritmo imposto aos trabalhos na Arqueologia de Contrato (ou Preventiva) é diferente do das pesquisas acadêmicas. A combinação entre a insuficiência de pesquisas e a existência de preconceitos arraigados na cultura brasileira torna a proteção do patrimônio arqueológico brasileiro uma tarefa espinhosa. Por isso, numa tentativa de aproximar a sociedade desse patrimônio, a portaria citada anteriormente determinou que, paralelamente às pesquisas arqueológicas,

\footnotetext{
${ }^{1} \mathrm{O}$ primeiro esclarecimento que se faz necessário está relacionado aos conceitos de proteção x preservação. Ao longo deste trabalho, o verbo proteger sempre se referirá ao ato de "sin. Apoiar, recomendar. Fomentar, desenvolver, incrementar, incentivar" (cf. FERNANDES, 1967) ou "v. (1680 cf. Laclsa) 5 t.d. promover ações para manter ou desenvolver (algo); fomentar, estimular, amparar $<p$. a pesquisa $><p$. as artes $><p$. o patrimônio público" (cf. HOUAISS et al., 2001), diferente do verbo preservar, que se refere ao ato "sin. Guardar, livrar, resguardar, defender" (cf. FERNANDES, 1967) ou "v. (sXV cf. FichIVPM) blindar, defender, guardar, imunizar, isentar, livrar, resguardar" (cf. HOUAISS et al., 2001). Contudo, o uso dos termos proteção e preservação podem adquirir conotações similares na medida em que indicam que determinado bem está sob cuidados, sendo amparado, ou socorrido. Segundo o Dicionário Houaiss (Houaiss et al., 2001), preservação "s.f. (1665 cf. AcSing) 1 m.q. conservação ('conjunto de medidas') 2 série de ações cujo objetivo é garantir a integridade e a perenidade de algo; defesa, salvaguarda, conservação <p. de um bem cultural>" e proteção "s.f. (sXV cf. FichIVPM) ato ou efeito de proteger(-se) 9 guarda ou tombamento de um bem cultural ou natural, feito pelo Estado".

${ }^{2}$ Embora desde a Resolução CONAMA N ${ }^{\circ} .001$ de 23 de janeiro de 1986 já estivesse definido que os Estudos de Impacto Ambiental desenvolveriam atividades ligadas ao meio socioeconômico, incluindo, nestas, os trabalhos técnicos em sítios e monumentos arqueológicos, históricos e culturais da comunidade.

3 Por exemplo, sítios identificados em pesquisas arqueológicas 'de contrato' podem não serem alvos de escavações ou projetos científicos se estiverem fora das áreas a serem diretamente impactadas por determinado empreendimento, embora dentro das suas áreas de influência.
} 
fossem elaborados programas de Educação Patrimonial (EP) junto às comunidades das áreas afetadas pelos empreendimentos. Entretanto, os problemas tendem a persistir, considerando-se que os programas de EP são pontuais e que não há continuidade nos processos educativos.

Esta tese defende que o turismo é uma alternativa para a proteção dos sítios arqueológicos e, ao mesmo tempo, para a geração de renda e melhorias sociais para as comunidades nas quais estes sítios se encontram. Nesse sentido, a preservação do patrimônio arqueológico pode e deve, pelo menos na maioria dos casos, ser vista pela sociedade como um investimento, já que o patrimônio preservado e acessível à visitação transforma-se num atrativo turístico do município, que, ao promovê-lo, gerará divisas para si e para o país.

Considerando que parte das discussões sobre Turismo Arqueológico no Brasil sugere que a pouca monumentalidade dos sítios seja um empecilho ao desenvolvimento da atividade turística, as seguintes hipóteses foram levantadas para o desenvolvimento desta tese:

- O desenvolvimento do Turismo Arqueológico no Estado do Amazonas é possível, apesar da falta de monumentalidade dos sítios;

- Ainda que os sítios arqueológicos locais não tenham, por si sós, potencial suficiente para atrair grandes correntes turísticas, nacionais ou internacionais, é possível aproveitá-los turisticamente.

O objetivo desta tese foi demonstrar a viabilidade do aproveitamento turístico do patrimônio arqueológico no município de Iranduba. Para isso, buscou-se, especificamente, apresentar propostas de uso sustentável de locais patrimoniais com o desenvolvimento de uma estrutura interpretativa dessa herança cultural para o uso no turismo.

Desta maneira, este trabalho apresenta uma gama de atrativos arqueoturísticos diferentes entre si, mas pensados em complementariedade, que podem ser incluídos em roteiros ecoturísticos já existentes localmente ou em novos roteiros voltados especificamente à arqueologia. Os atrativos propostos, se implantados, podem transformar Iranduba em um referencial para o Turismo Arqueológico no Brasil. 
A escolha do município em questão não foi aleatória. Esta tese integrou o Projeto Amazônia Central (PAC), coordenado pelo Prof. Dr. Eduardo Góes Neves, do Museu de Arqueologia e Etnologia (MAE) da Universidade de São Paulo (USP), também orientador deste trabalho. Assim como os demais participantes do PAC, em sua maioria orientandos do coordenador, este trabalho desenvolveu-se na região de abrangência do mesmo: a Amazônia central, onde se localiza o município de Iranduba.

Com o PAC, diversos projetos de pós-graduação foram viabilizados. Estes produziram muitas informações sobre temas específicos, mantendo, porém, um objetivo mais amplo e em comum, que é o entendimento da história dos povos que habitavam a região no período pré-cabralino. Além disso, os resultados das escavações em diversos sítios arqueológicos locais foram publicados em revistas nacionais e internacionais (p.ex. NEVES, 1998; LIMA et al., 2006), em dissertações de mestrado no âmbito do programa de pós-graduação do MAE/USP (DonAtTI, 2003; Lima, 2003; Almeida, 2007; Moraes, 2007; Portocarrero, 2007; Rebellato, 2007; Rapp Py-DANIEL, 2009), teses de doutorado (COSTA, 2009; LIMA, 2008) e em livros ou capítulos de livros (p.ex. NeVEs et al., 2003; NeVES, 1999; NeVES, 2006).

Apesar de toda essa produção, muitas questões permanecem em aberto e talvez nunca possam ser respondidas com certeza absoluta, como, por exemplo, quais etnias foram responsáveis pela produção de cerâmica de determinado estilo, ou o porquê da escolha de certo material por um grupo étnico e não por outro, entre tantas outras. Embora isso seja visto com naturalidade pelos arqueólogos (p. ex. LIMA, 2008), cientes das limitações do seu trabalho, para o público leigo, quase sempre são essas as informações que mais interessam (Quem? Por quê? e Para quê?). Como contar essa história, por meio dos fragmentos cerâmicos, e como preservar os sítios e os vestígios arqueológicos, principalmente "cacos de índio", que muitas vezes não fazem sentido para as comunidades atuais, são dois grandes desafios para a arqueologia.

Durante os anos de trabalho do PAC, o relacionamento entre a comunidade local e a equipe de pesquisa mostrava-se satisfatório, apesar de pouco abrangente. Por isso, o PAC mostrou- 
se atento a essas questões, estimulando trabalhos de Educação Patrimonial (CARNEIRO, 2009) e, neste caso, uma tese voltada ao Turismo Arqueológico ${ }^{4}$.

Desenvolver esta tese foi um grande desafio, pois, apesar de considerada uma ciência interdisciplinar, as questões relacionadas à formação do profissional em arqueologia ainda não são pensadas de forma unânime. Contudo, um projeto de Turismo Arqueológico vinculado a um programa de pós-graduação em Arqueologia faz com que a academia ofereça meios de divulgação das informações científicas obtidas (cf. Portaria SPHAN №. 007/ 1988) de forma direta, constante - uma vez que, implantada, a atividade turística tende a se perpetuar - e inovadora, já que ainda não existem muitos trabalhos sobre essa temática no Brasil.

Espera-se que a leitura desta tese seja proveitosa no sentido de despertar a atenção para a atividade turística como uma opção menos destrutiva de aproveitamento dos sítios arqueológicos brasileiros e que estimula a preservação dos mesmos. Por isso mesmo, defende-se aqui, deve ser mais difundida.

\footnotetext{
${ }^{4}$ No decorrer deste trabalho, o uso dos termos Turismo Arqueológico ou Arqueoturismo são entendidos como sinônimos e, dessa forma, podem ser usados em substituição um ao outro.
} 


\section{CAPÍtUlo I - Patrimônio ARQUeológico e TURISMo no BRASIL}

I am still surprised at how many in the conservation movement fear tourism, rather than recognizing it as a very real ally in finding the financial justification for protecting the cultural heritage. I think we have to tell all those people, 'Friends, the stakes are too high. Let us come together, let us celebrate our strength, and recognize our shortcomings, let us look for the common ground on which we can build and let us proceed from there and not argue about the peripheral issues ${ }^{5}$.

Ismail Serageldin, The World Bank (WMF, 1996)

Este capítulo dedica-se à apresentação das problemáticas que permeiam a relação do turismo com o patrimônio arqueológico brasileiro. Para isso, buscou-se apresentar e discutir, ao longo do texto, conceitos considerados importantes para a compreensão deste trabalho tanto por leitores das duas áreas envolvidas, quanto por leitores de áreas afins.

\footnotetext{
${ }^{5}$ Continua a surpreender-me o número de pessoas que, dentro do movimento de conservação, temem o turismo, em vez de reconhecê-lo como um aliado verdadeiramente real na busca de uma justificação financeira para proteger o patrimônio cultural. Acho que devemos dizer-lhes: "Amigos, os riscos são muito grandes. Vamos nos unir, vamos celebrar a nossa força e reconhecer as nossas limitações. Procuremos encontrar o denominador comum com base no qual possamos progredir e procedamos, a partir disso, sem discutir sobre questões secundárias" [Tradução: Luciana M. Guimarães].
} 
A Constituição da República, em seu art. 216, estabelece:

Constituem patrimônio cultural brasileiro os bens de natureza, material e imaterial, tomados individualmente ou em conjunto, portadores de referência à identidade, à ação, à memória dos diferentes grupos formadores da sociedade brasileira, nos quais se incluem:

I - as formas de expressão;

II - os modos de criar, fazer e viver;

III - as criações científicas, artísticas e tecnológicas;

IV - as obras, objetos, documentos, edificações e demais espaços destinados às manifestações artístico-culturais;

$\mathrm{V}$ - os conjuntos urbanos e sítios de valor histórico, paisagístico, artístico, arqueológico, paleontológico, ecológico e científico.

Assis (2011: 75) avalia que esse texto, embora avançado, "não traz um 'conceito' de patrimônio cultural" e, por isso, não deve ser utilizado para tanto. Nesse sentido, ele cita Machado (2007: 918), que diz que o:

[p]atrimônio cultural representa o trabalho, a criatividade, a espiritualidade e as crenças, o cotidiano e o extraordinário de gerações anteriores, diante do qual a geração presente terá que emitir um juízo de valor, dizendo o que quererá conservar, modificar ou até demolir. Esse patrimônio é recebido sem mérito da geração que o recebe, mas não continuará a existir sem o seu apoio.

Assim, "[o] patrimônio cultural é, antes de tudo, a reafirmação das identidades culturais dos povos e funciona como mediador entre o presente e o passado" (SOUZA, 2006). Porém, Silva (2000: 219) observa que "(...) toda a construção patrimonial é uma representação simbólica de uma dada versão da identidade, de uma identidade "manufacturada" pelo presente que a idealiza". Deste modo, nem todos os vestígios do passado podem ser considerados patrimônios. Essa consideração é uma escolha cultural, fruto de uma seleção consciente do que se deseja legar ao futuro, que mostra que algo é valioso individualmente ou socialmente. O patrimônio cultural compreende, portanto, todos os elementos que compõem a identidade de um grupo e que os diferenciam dos demais (SILVA, 2000).

Além disso, Silva (2000: 218) argumenta que "não podemos entender o património apenas como os vestígios tangíveis do processo histórico". Ou seja, ela destaca que patrimônio, além de ser composto por objetos materiais, também pode ser um aspecto da cultura que se torna importante para uma pessoa ou para comunidades inteiras. Esta visão fez crescer, nos últimos tempos, a relação do que é classificado como patrimônio, reconhecendo-se, 
inclusive, os chamados patrimônios imateriais (SANTANA, 1998) ou patrimônios culturais intangíveis ${ }^{6}$ (ScovazZI, 2011).

Assis (2011), no artigo O Patrimônio Cultural e a Tutela Jurídica das Identidades, apresenta uma discussão importante para esta tese: o patrimônio tem um caráter fluido e dinâmico e, como tal, não deveria ser alvo de preservação, no sentido de imobilização de um dado da cultura, mas sim de promoção. Para esse autor, a promoção do patrimônio cultural é permitir "direito amplo à informação histórica, à gênese dos significados, à compreensão profunda do homem e de seu lugar na história" (Assis, 2011: 77), além de ser:

[a] tutela da livre expressão coletiva dos povos, a defesa e a viabilização do diálogo intergeracional, capazes de atribuir sentido à vida daqueles para os quais, sem a compreensão histórica, o fluxo do tempo tornar-se-ia um amontoado sem sentido de fatos e acontecimentos.

De tal modo, quando se fala em patrimônio arqueológico brasileiro, refere-se a um conjunto de vestígios que são importantes para a sociedade nacional, pois carregam em si parte da história do país e têm "como função ajudar a estabelecer a ligação entre as gerações passadas e futuras, por meio da análise das relações sociais que nossos antepassados construíram em face do estudo da cultura material legada" (SOUZA, 2006). Esses vestígios englobam tanto objetos, que podem ser guardados em museus, quanto os próprios sítios arqueológicos ${ }^{7}$, que, sempre que possível, devem ser preservados in loco.

\footnotetext{
6 "The 'intangible cultural heritage' means the practices, representations, expressions, knowledge, skills - as well as the instruments, objects, artifacts and cultural spaces associated therewith - that communities, groups and, in some cases individuals recognize as part of their cultural heritage. This intangible cultural heritage, transmitted from generation to generation, is constantly recreated by communities and groups in response to their environment, their interaction with nature and their history, and provides them with a sense of identity and continuity, thus promoting respect for cultural diversity and human creativity" (UNESCO, 2003).

"O termo 'patrimônio cultural intangível' refere-se a práticas, representações, expressões, conhecimento e competências - bem como os instrumentos, os objetos, os artefatos e os espaços culturais associados a todos eles - que as comunidades, os grupos e, em alguns casos, alguns indivíduos reconhecem como parte de seu patrimônio cultural. Este patrimônio cultural intangível, transmitido de geração à geração, está em constante processo de recriação por parte de comunidades e grupos, em resposta a seus ambientes, a suas interações com a natureza e com as suas histórias, fornecendo-lhes um sentimento de identidade e continuidade e promovendo, deste modo, respeito pela diversidade cultural e pela criatividade humana" [Tradução: Luciana M. Guimarães].

7 "São considerados sítios arqueológicos: as jazidas de qualquer natureza, origem ou finalidade, que representem testemunhos da cultura dos paleoameríndios; os sítios nos quais se encontram vestígios positivos de ocupação pelos paleoameríndios; os sítios identificados como cemitérios, sepulturas ou locais de pouso prolongado ou de aldeamento 'estações' e 'cerâmicos'; e as inscrições rupestres ou locais e outros vestígios de atividade de paleoameríndios" (Lei n³.924 de 26 de julho de 1961).
} 
Ao chegarem ao Brasil, oficialmente em 1500, os portugueses depararam-se com habitantes autóctones, denominados àquela época de índios. Como e quando esses índios chegaram até aqui, de que local eles partiram e o caminho que percorreram ainda são questões controversas na pré-história brasileira, que é o período de ocupação do território hoje conhecido como Brasil antes da chegada dos europeus. Ainda há muito para se saber sobre esse período, que é estudado pelos arqueólogos.

Durante um bom tempo, acreditava-se que a chegada dos primeiros homens ao continente sul-americano tivesse ocorrido por volta de 12.000 anos atrás, após terem percorrido toda a América do Norte. Naquele período, com temperaturas mais baixas em todo o planeta, uma "ponte de gelo" entre a Ásia e o Alaska (Behringia) teria se formado e permitido a passagem dos primeiros grupos humanos, provavelmente atrás de manadas de grandes animais (ROOSEVELT, 2000: 35). Esta teoria tem sido bastante debatida nos últimos anos, com o aparecimento de novos sítios arqueológicos com datas possivelmente anteriores à média até então aceita, como é o caso do Boqueirão da Pedra Furada, no Piauí, de Santa Elina, no Mato Grosso e de Monte Alegre, no Pará. A análise de um crânio apelidado 'Luzia', descoberto em Minas Gerais, evidenciou feições negróides, totalmente diferente dos indígenas atuais, descendentes de asiáticos (Prous, 2006), levantando novos questionamentos. Hoje em dia, muitos pesquisadores acreditam que podem ter acontecido outras levas de migração através da Behringia, em períodos muito mais remotos, por volta de 30.000 ou 40.000 anos atrás. Tal fato justificaria toda a diversidade cultural, linguística e biológica existente nas Américas. Esse período é chamado de Paleoindígena ${ }^{8}$.

O registro arqueológico mostra que, no período Arcaico, entre 10.000 e 2.500 anos atrás, já havia presença humana em todo o continente americano e que, além disso, essa teria sido uma época de grande diversificação cultural. Processos de adaptação aos diferentes ambientes fizeram com que a densidade populacional aumentasse significativamente. É desse período a chamada arte rupestre, que persiste até hoje em vários abrigos e grutas rochosas no Brasil (DE BLASIS, 2001).

\footnotetext{
8 Segundo Schmitz (2000: 55-56), "No Brasil, as periodizações locais e regionais apresentam algumas controvérsias (...). No Velho Mundo, os nomes geralmente usados na periodização universal são: Paleolítico (Inferior, Médio e Superior), Mesolítico, Neolítico e Civilização ou Urbanismo (Pré-Clássico, Clássico e PósClássico). Os nomes americanos aproximadamente correspondentes são: Período Lítico, que pode ser usado com sentido semelhante ao Paleolítico e dividido em um período Pré-Pontas e outro Paleoíndio; Período Arcaico (em vez de Mesolítico); Período Formativo (em vez de Neolítico) (...)".
} 
O período seguinte, o Formativo, vai de cerca de 2.000 anos atrás até a chegada dos europeus e, segundo De Blasis (2001):

(...) o cenário arqueológico brasileiro é marcado pelos vestígios de sociedades com uma economia não mais baseada na caça e na coleta, mas plenamente agrícola, sendo comum encontrar grandes aldeias com milhares de fragmentos de vasilhas cerâmicas, seu traço arqueológico mais típico e comum.

Atualmente, o Instituto do Patrimônio Histórico e Artístico Nacional (IPHAN) possui em seu cadastro pelo menos 17.000 sítios arqueológicos espalhados pelo país. São sítios a céu aberto ou em abrigos sob rocha, sambaquis, de Terra Preta, entre tantos outros, nos quais é possível encontrar diferentes vestígios ( $p$. ex. pinturas e gravuras rupestres de várias tradições, materiais líticos de culturas variadas e cerâmicas com decorações distintas). Há também variações no tamanho, na relevância científica e no grau de preservação dos mesmos.

Quanto mais as pesquisas arqueológicas se desenvolvem, mais se percebe a diversidade que existia: povos caçadores-coletores, pescadores-caçadores-coletores, sambaquieiros e ceramistas (TenóRIO, 2000). Essas sociedades deixaram seus registros no ambiente e, também, vestígios materiais.

A arqueologia brasileira engloba, além da pré-história, outros períodos. Aquele que compreende desde o contato com os europeus até a era industrial, por exemplo, é conhecido como Arqueologia Histórica. Além disso, existem outras nomenclaturas que buscam especificar o trabalho que está sendo realizado como, por exemplo, as seguintes subdivisões (precedidas da palavra arqueologia): Subaquática, Urbana, Indígena, Quilombola, da morte, da paisagem, entre tantas outras.

Embora o contato com o europeu tenha provocado o extermínio de muitos indígenas, bem como a perda de muitos costumes e crenças, ainda hoje, segundo a FUNAI ${ }^{9}$ :

[o] Brasil possui uma imensa diversidade étnica e lingüística, estando entre as maiores do mundo. São 215 sociedades indígenas, mais cerca de 55 grupos de índios isolados, sobre os quais ainda não há informações objetivas. 180 línguas, pelo menos, são faladas pelos membros destas sociedades, as quais pertencem a mais de 30 famílias lingüísticas diferentes.

\footnotetext{
${ }^{9}$ Informações disponíveis no site: http://www.funai.gov.br/indios. Acesso em 24 de abril de 2010.
} 
Indígenas, europeus e africanos, trazidos para trabalhar nas lavouras de cana-de-açúcar e café, misturaram-se. A sociedade brasileira foi, assim, composta por esses diferentes povos (Pena et al., 2000; FreYre, 1933). Entretanto, como destacam Funari e Noeli (2005: 107) "embora mais de 40 milhões de brasileiros tenham antepassados indígenas, essa herança é mal conhecida e mesmo rejeitada, por ser considerada parte de uma cultura inferior".

A arqueologia pode ajudar a mudar essa realidade. Contudo, a baixa expressividade dessa ciência no país não contribui para esse resultado, haja vista o pequeno número de instituições científicas, e de profissionais atuantes, em contraste com as dimensões territoriais nacionais e, consequentemente, as poucas pesquisas contínuas que permitam conhecimentos sistemáticos nessa área do conhecimento.

A arqueologia é uma ciência que busca recompor uma história que não está escrita, mas que pode ser acessada pelas gerações atuais através dos vestígios deixados pelas populações antigas. As pesquisas arqueológicas não se limitam à busca por artefatos (objetos usados, modificados ou feitos por pessoas). Nos sítios arqueológicos (locais onde traços de atividade humana são encontrados), também há uma série de informações contida nas feições encontradas (buracos de estaca, fossos, pisos) e nos ecofatos (registros orgânicos e ambientais como o próprio solo, ossos de animais e restos de plantas) (RENFREW E BAHN, 2004). Essa diversidade de registro torna a arqueologia uma ciência bastante interdisciplinar, implicando uma constante interação com várias outras áreas do conhecimento. Os resultados obtidos pelos arqueólogos dependem, quase sempre, de resultados de pesquisas que provém de outras ciências, dentre as quais a física, a química, a botânica e a geologia.

Como apontam Renfrew e Bahn (2004: 12), "archaeology is partly the discovery of treasures of the past, partly the meticulous work of the scientific analyst, partly the exercise of the creative imagination $^{\prime 10}$. Deste modo, o trabalho do arqueólogo não se resume ao campo, estende-se ao laboratório e, muitas vezes, o mesmo material é analisado tempos depois à luz de novas tecnologias, fazendo com que os resultados possam se alterar profundamente.

Tudo isso, no entanto, depende fundamentalmente de um trabalho de campo bastante criterioso, partindo de um projeto de pesquisa que aponta o que se deseja saber, os

\footnotetext{
${ }^{10}$ A arqueologia é, em parte, tanto a descoberta de tesouros do passado, o trabalho meticuloso do cientista, quanto o exercício da imaginação criativa [Tradução: Luciana M. Guimarães].
} 
métodos que se planeja utilizar e as contribuições que poderão advir dos seus resultados (GAMBLE, 2004). Em campo, inicia-se pelo reconhecimento da área e, a partir daí, sucedem-se etapas de levantamento topográfico (Ilustração I.1), delimitação da área do sítio arqueológico e da sua profundidade, por meio de sondagens no terreno. Essas etapas causam pouco ou nenhum impacto sobre os vestígios, mas a escavação é altamente impactante: uma vez escavado, o sítio e todas as informações ali encontradas são "destruídos". Por isso, independente da orientação teórica e metodológica seguida pelo arqueólogo responsável por uma escavação, o registro tem um grande peso.

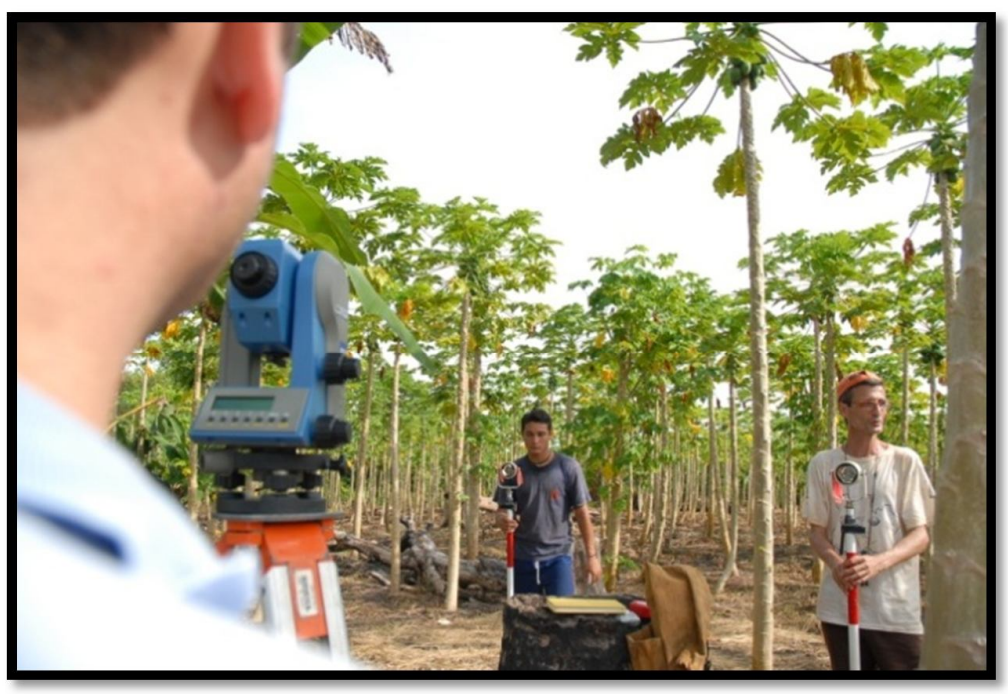

Ilustração I.1: Levantamento topográfico (FotografiA: Val de Moraes/ Acervo PAC).

Caso o contexto de uma escavação não tenha sofrido interferências após sua formação, ele é denominado primário, caso tenha sido perturbado pela ação de saqueadores, ações naturais ou atividades sociais, é chamado secundário. Em qualquer um dos casos, a matriz (o material em volta do achado), a proveniência do vestígio (posição horizontal e vertical dentro da matriz) e as associações percebidas (ocorrência junto a outros registros, usualmente na mesma matriz) precisam ser reconhecidas e registradas. O registro é feito em fichas previamente elaboradas onde é anotado tudo que está sendo visto pelo escavador, sendo 
complementado por desenhos e fotografias que permitem ilustrar e esclarecer as informações descritas (Ilustração I.2).
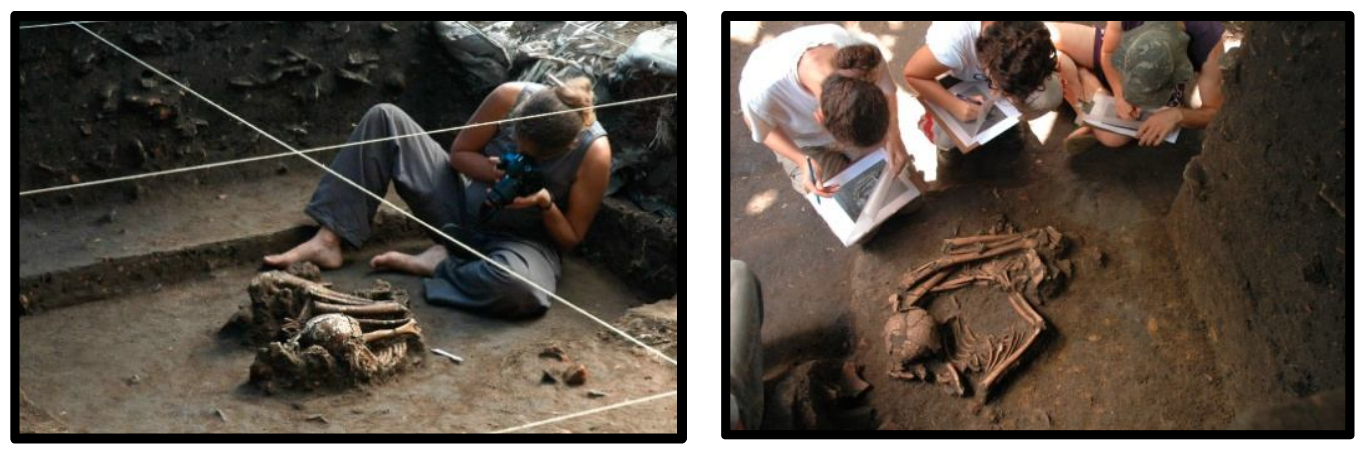

Ilustração I.2: Imagens de procedimentos em campo/registro (FotografiAs: Val de Moraes. Acervo PAC).

Os materiais recolhidos (sedimento, cerâmica, ossos, carvão, líticos etc.) são identificados por meio de diversas informações, como por exemplo, o nome do sítio e a sua sigla, o nível de onde o material foi retirado, as coordenadas da unidade, a data e o nome dos componentes da equipe de escavação (Ilustração I.3).

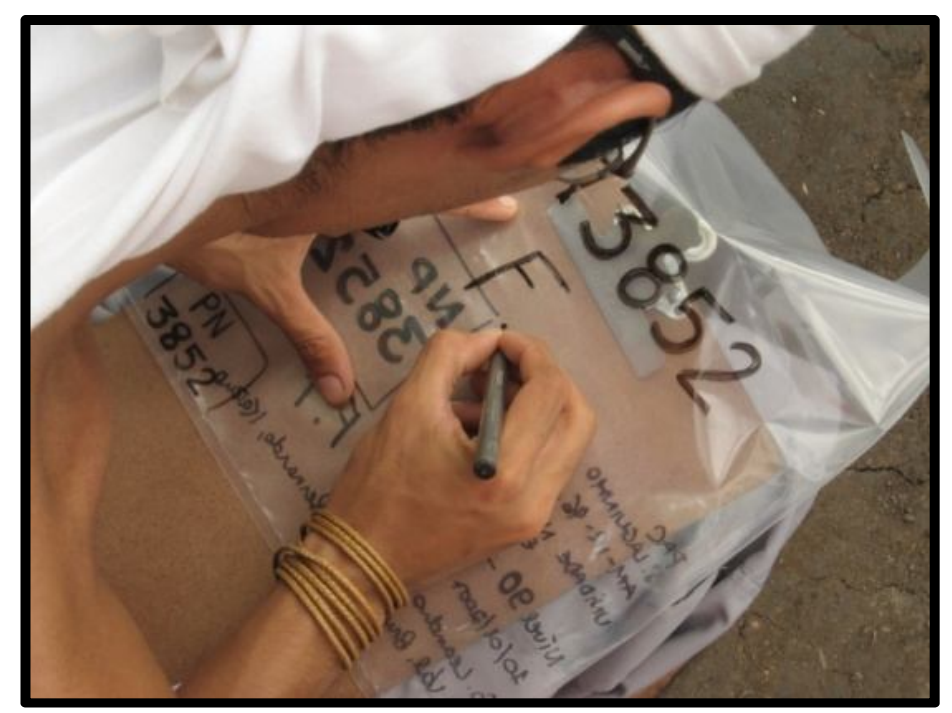

llustração I.3: Exemplo de embalagem para recolhimento de sedimentos e vestígios (FotografiA: Val de Moraes. Acervo PAC).

Além disso, o sedimento retirado a cada nível é submetido a peneiramento, cujo objetivo é coletar vestígios que passaram despercebidos na escavação (Ilustração I.4). 

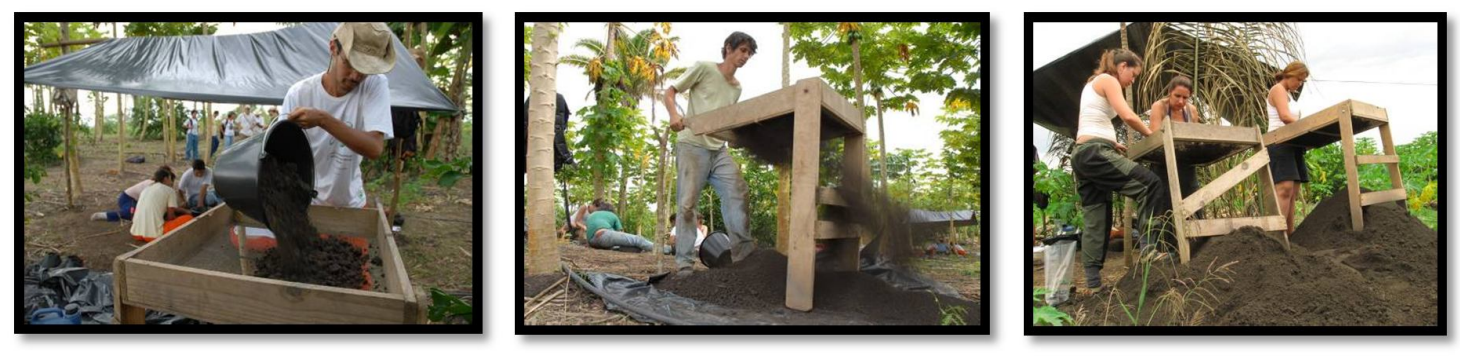

Ilustração I.4: Imagens de procedimentos em campo/peneiramento (FotografiAS: Val de Moraes. Acervo PAC).

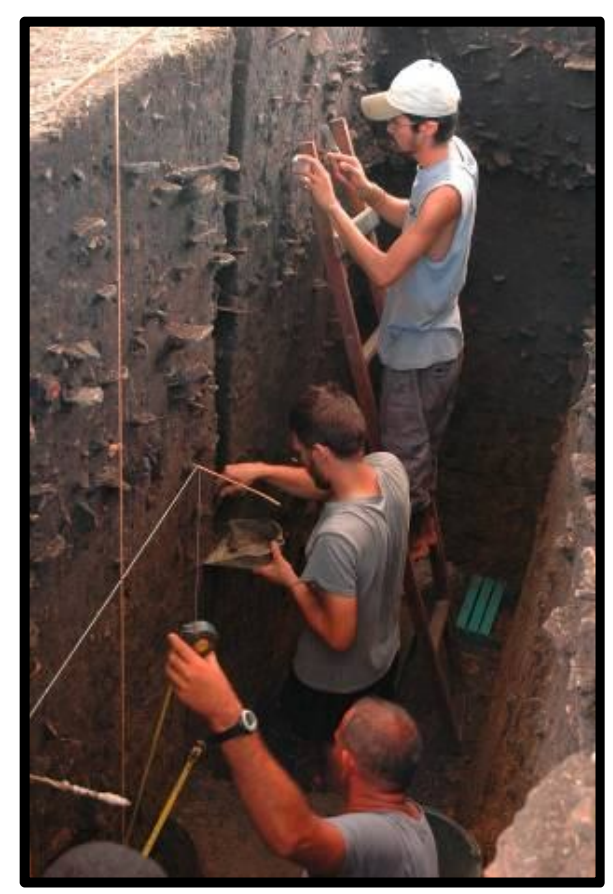

A "leitura" dessas informações acontece horizontalmente a cada nível (pisos) e, ao final, verticalmente (perfis). No primeiro caso, é possível compreender quais atividades ocorreram ao mesmo tempo e, no segundo, como isso mudou ao longo do tempo (Renfrew e BAHN, 2004). Como reflete Gamble (2004:61), "[a] stratigraphic analysis unravels the sequence of the creative process of living in the landscape over periods of time ${ }^{\prime 11}$.

llustração I.5: Perfil de escavação em sítio de Terra Preta (Fotografia: Val de Moraes. Acervo PAC).

Todas as informações resultantes desse trabalho exaustivo em campo e em laboratório permitem entender como funcionavam e se transformavam tanto as sociedades humanas que não deixaram registros escritos (FUNARI, 2003), como também complementar o conhecimento sobre aquelas que deixaram. Isso é relevante para o entendimento da história nacional e permite rever atitudes frente ao ambiente em que se vive. Deve-se ressaltar que faz parte das obrigações dos arqueólogos publicar os dados dos trabalhos por eles realizados. A não publicação deliberada, conforme Renfrew e Bahn (2004), pode ser vista

\footnotetext{
${ }^{11}$ Uma análise estratigráfica desvenda a sequência do processo criativo de viver na paisagem ao longo de períodos de tempo [Tradução: Luciana M. Guimarães].
} 
como uma forma dupla de roubo, já que envolve o mau uso do dinheiro alheio e a retenção de informações únicas.

Enquanto a afirmação 'A arqueologia é importante' é praticamente um bordão para os profissionais da área, a pergunta 'Importante para quem?', por sua vez, parece ser frequentemente o eco a essa afirmação para qualquer pessoa que não tenha conhecimento da área. De fato, a consideração de que algo tem ou não importância pode ser difícil de ser apoiada a depender da situação na qual ela é feita. A realidade do patrimônio arqueológico brasileiro demonstra que atualmente sua dita importância não é reconhecida por grande parcela da sociedade.

Deve-se analisar a situação: o país (estado) é composto pelo seu povo (componente humano), seu território (a base física) e por um governo soberano, que exerce o poder emanado pelo povo. Teoricamente, quando uma parcela da sociedade reconhece a importância de algo e faz, com base no seu direito, com que esse algo passe a ser assumido pelo estado como importante, legalmente, sua importância passa a ser atestada. De fato, a legislação brasileira reconhece a importância de assuntos diversos, da questão das liberdades individuais a questões básicas como as de saúde, educação e cultura e, também, muito em voga atualmente, questões ligadas ao ambiente. Entretanto, em muitos momentos, a realidade brasileira passa a impressão de que esses temas não são tão importantes, inclusive para o próprio estado.

Tomando-se como exemplo a situação da saúde no Brasil, pode-se questionar o seguinte: se a saúde é algo realmente tão importante para a sociedade, e isso é reconhecido legalmente, por que se assiste diariamente ao caos vivenciado na saúde pública? Uma série de explicações pode ser dada em relação a essa questão, o que não vem ao caso nesse trabalho. O que é relevante afirmar aqui é que, indubitavelmente, a saúde é algo percebido como importante por todos (sociedade e governos, ricos ou pobres) e que cada parcela da sociedade vai, em algum momento e em níveis diferenciados, se deparar com questões que 
a façam reagir frente à realidade da saúde no país. Ninguém precisa ser convencido de que a saúde de um povo é importante, mesmo assim a situação da saúde no país é crítica.

Esse raciocínio serve apenas para apontar que, em se tratando de patrimônio arqueológico, o desafio torna-se ainda maior. O reconhecimento da importância desse patrimônio por parte do estado (através de legislação específica) e por parte de grupos específicos não o coloca no mesmo nível de importância para outras parcelas da sociedade. Então, se numa luta de muitos, como é o caso da saúde, os problemas enfrentados já são tão grandes, numa briga de poucos, esses problemas são, sem dúvida alguma, ainda maiores.

Sim, a arqueologia é importante. É importante enquanto ferramenta de preservação de uma memória coletiva ${ }^{12}$ que existe (já que o passado é um fato), mas que ainda não foi, em muitos casos, decifrada. Nas palavras de Silva (2000: 219):

Os objectos do passado proporcionam estabilidade pois se o futuro é aquele destino essencialmente incerto e o presente aquele instante fugaz, a única certeza que o ser humano possui é a verdade irrefutável do passado.

Na realidade brasileira, a arqueologia quase sempre se relacionada a um período para o qual não existem registros escritos, sendo, portanto, a única forma de entendimento do passado. Ainda assim, num país onde os problemas socioeconômicos são tão exacerbados, faz-se difícil compreender a razão do porquê de se investir no conhecimento do passado, se isso pode implicar em custos elevados e em entraves econômicos. Para a população, por exemplo, algumas questões apresentam-se: Por que investir no conhecimento do passado em vez de se investir em saúde, moradia e educação? Por que não vender peças arqueológicas, se isso pode gerar dinheiro que comprará comida para a sua família ou para membros da sua comunidade? Essas questões não são novidades e, certamente, há pesquisadores preocupados com elas; assim como também há, felizmente, uma parcela de cidadãos comuns interessados em discuti-las. Contudo, juntas, estas pessoas ainda constituem uma parcela pequena da sociedade.

\footnotetext{
${ }^{12}$ O conceito de memória coletiva, bem como a forma como se dá a sua construção, é abordado por diversos autores em arqueologia. Para uma síntese e acesso a referências bibliográficas fundamentais sugere-se ver: LIMA, 2007.
} 
Nessa direção, aumentam as afirmações de que o conhecimento do patrimônio arqueológico é a chave para a sua preservação, e a educação é, frequentemente, a forma apontada para que esse conhecimento chegue ao público (MORLEY, 2000).

Porém, de que educação se trata aqui? A educação subdivide-se em educação formal (praticada no âmbito escolar), não-formal (processos educacionais que podem acontecer fora do sistema de ensino, escolas e universidades, com caráter complementar) e a educação informal (aquela recebida no decurso da nossa vida e resulta no desenvolvimento de conhecimentos e valores) ${ }^{13}$.

O Brasil parece estar alcançando resultados tanto em relação à educação formal, através do aumento significativo, nos últimos anos, do número de cursos superiores e de pósgraduação voltados à arqueologia (ZANETTINI, 2010), quanto à educação não-formal, principalmente desde a entrada em vigor da Portaria № 230/2002, que considerou a Educação Patrimonial (EP) como parte inerente dos estudos arqueológicos em Estudos de Impacto Ambiental (EIA).

Segundo Horta (1996: 06), a EP é "um processo permanente e sistemático de trabalho educacional centrado no Patrimônio Cultural como fonte primária de conhecimento e enriquecimento individual e coletivo". Essa autora ainda esclarece que a EP "consiste em provocar situações de aprendizado sobre o processo cultural e seus produtos $e$ manifestações, que despertem nos alunos o interesse em resolver questões significativas para sua própria vida, pessoal e coletiva" (HORTA, 1996: 08). A EP é vista, ainda, segundo Valecillo (2009: 274):

(...) como um processo pedagógico centrado em las percepciones, conocimientos y valores que subyacen em uma sociedad. De esta manera, el bien patrimonial se convierte em um recurso para el aprendizaje, capaz de conectar al ciudadano com su diversidad cultural e su entorno social.

Embora existam diversas linhas de trabalho com a EP, não restam dúvidas de sua ligação com contextos educativos, sejam eles escolas, instituições museológicas ou direcionados às comunidades do entorno de obras, devido à exigência legal. Dessa forma, parece claro que uma parcela significativa da população brasileira não tem acesso aos principais programas

${ }^{13}$ Fonte: site do INEP/ Ministério da Educação. Acesso em: 29/05/2009. 
de EP e não encontra meios para conhecer o patrimônio. Esta parcela é formada, principalmente, por adultos e jovens fora do ambiente escolar ou distantes de locais onde projetos de Educação Patrimonial, atrelados aos EIA, estejam sendo realizados.

Outras propostas, como a implantação de museus de arqueologia e a realização de exposições, também têm aumentado nos últimos anos, constituindo-se em mecanismos de inclusão. Contudo, para conseguir trazer a população para esses locais, é necessário um esforço suplementar que nem sempre tem sido satisfatório: o de divulgação. Além disso, poder-se-ia questionar a atratividade de muitos desses espaços, geralmente carentes de equipamentos audiovisuais e interativos, contando apenas com banners pendurados em paredes, além de algumas vitrines.

Porém, não é do escopo desse trabalho julgar a efetividade dessas ações, até mesmo porque todas são importantes diante do objetivo maior de tornar a arqueologia uma ciência mais acessível a todos. Pensa-se aqui, no entanto, que o turismo pode ter atuação importante nesse processo de aproximação das pessoas ao patrimônio, atingindo:

(i) uma parcela da comunidade do entorno de sítios arqueológicos, por meio de processos de planejamento participativo do turismo na localidade, de programas de treinamento e capacitação para diversas atividades turísticas e/ou para serviços complementares, onde a temática da arqueologia/pré-história deve ser incluída, quando da existência de patrimônio arqueológico na localidade;

(ii) o público - principalmente os moradores das grandes cidades - que hoje se encontra fora do ambiente escolar e que não frequenta exposições de arqueologia por falta de conhecimento e/ou interesse, por meio da possibilidade de vivenciar experiências de Turismo Arqueológico em suas viagens de férias ou, até mesmo, de trabalho. Se, ao aproximar-se do patrimônio arqueológico, a pessoa obtiver informações interpretadas corretamente, muito possivelmente um elo de sensibilização será formado.

Esta tese não pretende propor a substituição de nenhuma dessas atividades pelo turismo. Pelo contrário, defende que a somatória deste às demais atividades citadas amplia as oportunidades de disseminação desse conhecimento tão necessário como parte da 
educação informal que se pode receber ao longo da vida. E isso é, verdadeiramente, algo urgente, já que o crescimento das cidades, a realização de obras públicas, além de atividades cotidianas como as extrativistas e agropecuárias, têm provocado incontáveis prejuízos ao patrimônio arqueológico brasileiro.

Ressalta-se que, a cada sítio arqueológico destruído ou danificado, diminuem as possibilidades de alinhavar o conhecimento dessa história antiga. Como afirma Martin ( $\mathrm{s} / \mathrm{d}$ ):

El peligro de la pérdida total o parcial de nuestra herencia cultural, material e inmaterial, es tan grave como la pérdida de la salud pública, la identidad, la libertad de expresión o el acceso a una vida digna. El derecho a su acceso por parte de la sociedad es similar también a esos otros derechos humanos irrenunciables.

Todavia, no Brasil, em vez de ser percebido sob esta ótica, o turismo tem sido apontado, frequentemente, como um fator de destruição do patrimônio arqueológico. Por isso, apresentam-se algumas reflexões: (i) é muito comum ouvir exemplos dados em comunicações orais, em eventos na área de arqueologia, que não correspondem, de fato, à atividade turística, demonstrando que o assunto está sendo debatido a partir de bases conceituais frágeis, fundamentadas, normalmente, mais em preconceitos com a atividade turística do que em análises concretas. Muitos casos ouvidos durante a elaboração deste trabalho diziam respeito a ações de vandalismo praticadas pela comunidade local em sítios arqueológicos que possuíam algum tipo de visitação e, por isso mesmo, frequentemente confundidas com turismo. Nesses casos, os danos mais comuns foram pontuais, como pichações sobre pinturas ou gravuras rupestres e venda de material arqueológico. Em relação a este último exemplo, são praticamente inexistentes relatos brasileiros de sítios que tenham sido escavados pela população por inteiro, ou quase por inteiro, para retirada e venda de peças; (ii) não é possível analisar, sob a ótica dos impactos gerados pela visitação, os exemplos de Turismo Arqueológico no Brasil, simplesmente porque as experiências são tão poucas e, quase sempre em escalas tão pequenas, que não existem dados que permitam tal análise. Empiricamente, colocado ao lado dos outros fatores causadores de danos ao patrimônio arqueológico, o turismo seria o de menor abrangência e gravidade. Exemplificase: os danos causados pela implantação de uma grande obra de infraestrutura (barragem, gasoduto, rodovia etc.) são, na realidade, incalculáveis. Mesmo com a realização dos EIA, localizando, mapeando e resgatando sítios, muitas dessas obras são bastante extensas, contando com algumas dezenas ou centenas de quilômetros e, frequentemente, a 
quantidade de sítios encontrados é bastante significativa e nem tudo pode ser devidamente controlado e analisado. Ainda que se considerem os EIA como uma atitude em benefício do patrimônio, há insatisfação entre os próprios profissionais da área em relação à forma como eles vêm sendo realizados (DIAS, 2010). Além disso, não é raro ouvir relatos de empresas que continuam a descumprir a legislação, iniciando as obras antes mesmo da chegada dos arqueólogos e são pouquíssimos os exemplos onde a arqueologia tenha conseguido ser o mote principal do impedimento de uma determinada obra de grande porte. Por outro lado, no exemplo concreto de arqueoturismo mais conhecido no Brasil, a Serra da Capivara, no Piauí, existem 127 (cento e vinte e sete) sítios arqueológicos abertos à visitação. Neste local, há uma infraestrutura que ajuda no distanciamento dos turistas dos vestígios observados (Ilustração I.6). Embora existam diversos relatos de danos ao patrimônio arqueológico local, todos se relacionam à presença de invasores ${ }^{14}$ na área do parque, principalmente com objetivo de caça e coleta predatórias, e não ao turismo e a ações de turistas.
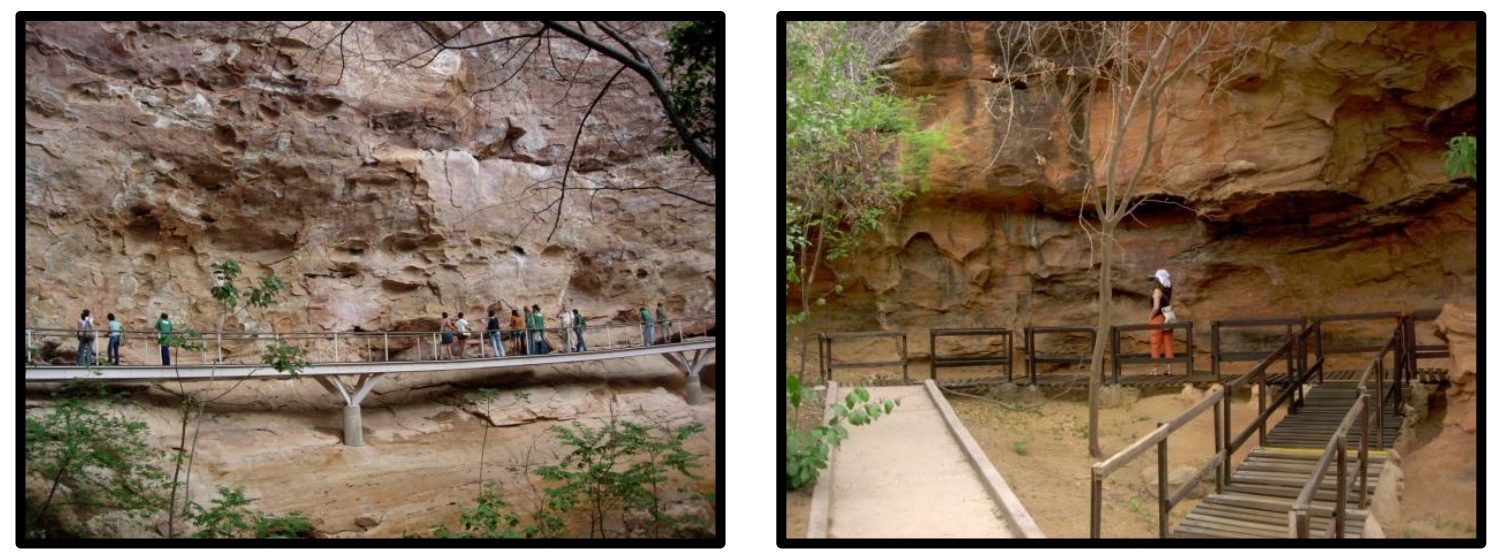

14 Embora possa ser entendido como um posicionamento, o termo 'invasor' foi usado no sentido estrito da palavra, designando pessoas que adentram/invadem a área do Parque Nacional para atividades que não são permitidas naquela categoria de UC (de proteção integral). Não se pretende, de forma alguma, adentrar em discussões sobre conflitos relacionados ao processo de criação deste PARNA. Sobre a importância da criação e manutenção de uma UC de proteção integral, em relação à preservação do patrimônio arqueológico indica-se a leitura de "Parque Nacional Serra da Capivara. Modelo de Preservação do Patrimônio Arqueológico Ameaçado" (GUIDÓN, 2007). Sobre conflitos gerados, com diversos grupos de atores sociais, pela implantação do PARNA Serra da Capivara e outras UC locais sugere-se a leitura da tese "O povo do Zabelê e o Parque Nacional da Serra da Capivara no Estado do Piauí - Tensões, Desafios e Riscos da Gestão Principiológica da Complexidade Constitucional" (SOUZA, 2009). 

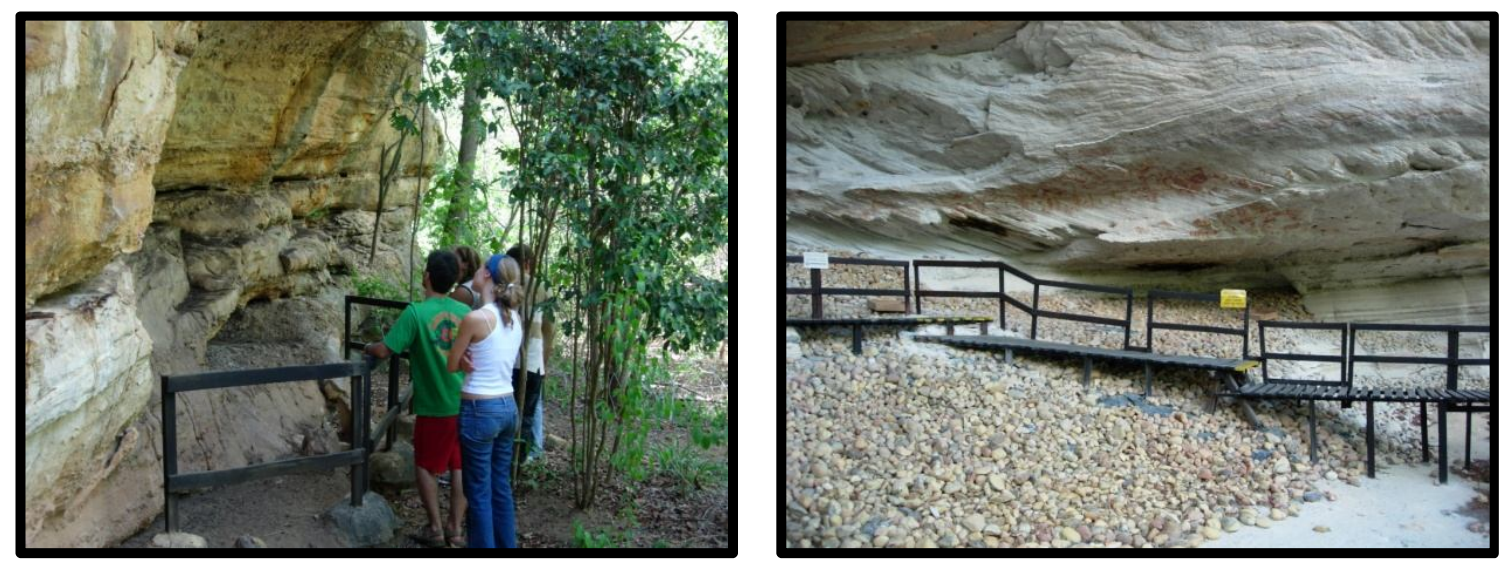

Ilustração I.6: Infraestrutura existente no Parque Nacional da Serra da Capivara, Piauí (FotogRAFIAS: Adriana Guimarães, 2006).

Com base nesse raciocínio, avaliou-se pertinente fazer algumas observações em relação às principais preocupações com o patrimônio arqueológico no Brasil:

1) O país passa, atualmente, por uma fase de crescimento econômico, durante a qual muita ênfase é dada à construção de infraestrutura. Muitas obras de grande porte foram e estão sendo realizadas nos últimos anos. Essas obras são o principal agente de destruição do patrimônio arqueológico brasileiro e, cada vez mais, assustam pelo volume de sítios envolvidos, com pouco ou nenhum benefício gerado para as comunidades locais;

2) O turismo, por sua vez, também pode causar impactos negativos. Porém, o desenvolvimento da atividade arqueoturística ainda é tão incipiente no Brasil que a maior preocupação dos profissionais envolvidos deveria ser a de produzir conhecimento sobre a atividade e, paralelamente, disseminar condutas de 'Melhores Práticas'. Tais condutas podem auxiliar a mitigar possíveis impactos ao patrimônio arqueológico a partir do planejamento do Turismo Arqueológico, o que parece ser mais adequado ao contexto brasileiro atual;

3) As características do patrimônio arqueológico determinam o tipo e a extensão de impacto que a visitação turística pode causar. Por exemplo, num sítio histórico, com ruínas de prédios antigos, a principal preocupação é com a quantidade de pessoas 
que podem circular pelo local e a possível remoção de vestígios (i.e. azulejos, metais, louças etc.). Num sítio rupestre, a preocupação será, provavelmente, com a proximidade dos turistas dos vestígios, impedindo pichações ou retirada de vestígios. Em alguns casos, como o da Gruta de Lascaux, na França, o gás carbônico resultante da respiração dos visitantes foi o fator causador de danos às pinturas. Desse modo, entende-se que cada caso deve ser analisado criteriosamente. Porém, para todos eles, há uma ação que poderá minimizar ou anular o risco de danos. Tal fato deve ser sempre considerado ao se pensar em Turismo Arqueológico;

4) De todas as situações em que o patrimônio arqueológico encontre-se em risco, as relacionadas ao turismo são as em que há maiores chances de posicionamento da comunidade em benefício da conservação do mesmo. Obras de infraestrutura, são, normalmente, bem vindas, porque trazem perspectivas de melhorias sociais e econômicas à comunidade, fazendo com que, em geral, as pessoas prefiram uma obra de infraestrutura a tentativas de conservação dos vestígios arqueológicos ou históricos. Ainda que a comunidade defenda o seu patrimônio e impeça determinada obra impactante, os custos dessa ação terão que ser sustentados a longo prazo. 0 turismo apresenta-se como uma das poucas opções para custear a conservação desses espaços.

Desenvolver projetos de turismo num ambiente acadêmico, com atores de áreas distintas, ainda é um desafio. Como para a arqueologia brasileira, no âmbito das discussões acadêmicas, esse tema é relativamente novo, são frequentes as opiniões preconceituosas em relação à atividade turística. Qualquer discussão parece menosprezá-la, tanto enquanto atividade econômica complexa, quanto como ciência ${ }^{15}$, na qual existem profissionais qualificados, produzindo conhecimentos que nem sempre estão sendo aplicados pelo poder público. As opiniões simplistas chegam mesmo a desprezar o potencial benéfico da atividade

\footnotetext{
${ }^{15}$ Embora controversa, esta tese compartilha com outros autores a visão do turismo como ciência: "há de se considerar que o turismo não possui um método científico próprio, o que causa polêmica por visões divergentes quanto à sua cientificidade. No entanto os estudos realizados na área de turismo utilizam-se do caráter inter, multi e transdisciplinar dessa área de conhecimento, graças à sua ampla abrangência, o que possibilita a realização de pesquisas científicas com respaldo e confiabilidade dignas de uma ciência como a matemática" (CRUz et al. 2008: 113-114). Ou ainda, nas palavras de Flores (2005: 143) "as ciências humanas não poderiam deixar de abraçar esse gosto emotivo pelo futuro e acolher com agrado a ciência nova que habita entre nós, a ciência do turismo. Seria preciso reconhecer que a cientificidade e a disciplinaridade, no âmbito dos estudos turísticos, já possuem uma maturidade de, pelo menos, duas décadas".
} 
nos campos social, cultural e econômico, bem como ignoram a formação acadêmica do profissional da área.

Esperar, por exemplo, como é corrente em arqueologia, que os trabalhos de turismo estejam diretamente ligados aos de Educação Patrimonial (EP) mostra exatamente essa simplificação. A possibilidade de trabalhos educativos dentro de um trabalho de turismo pode variar sensivelmente a depender da etapa de desenvolvimento em que a atividade se encontra. Na fase de planejamento, por exemplo, pode-se realizá-los como parte de cursos profissionalizantes. Na fase de operação, é possível realizá-los com visitantes, a depender do perfil do grupo recepcionado, por exemplo, com um grupo em 'viagem de conhecimento'. Entretanto, para a maioria das situações, nesta fase, é muito mais pertinente utilizar a Interpretação Patrimonial (IP) do que a EP, conforme é percebido em diversos manuais de boas práticas para turismo, turismo sustentável e Turismo Arqueológico - onde não se encontram referências à EP (PEDERSEN, 2002; CARTER, 2001; AIA, s/d).

Sendo assim, cabe apresentar conceitualmente o turismo, objetivando esclarecer que é possível desenvolver uma atividade turística planejada, que se sustente ao longo do tempo, dê retornos positivos às comunidades locais e auxilie na conservação do patrimônio arqueológico.

\section{I.1. Aspectos Conceituais e Práticos do Turismo.}

O grande caracterizador da atividade turística é a existência de um turista. Embora pareça óbvio, a caracterização de uma pessoa em trânsito não é tão simples, e essa não é uma preocupação acadêmica recente. Cohen (1974 apud Ross, 2001:14) selecionou sete características da viagem turística que permitem diferenciar turistas de outros viajantes, sendo elas: 
1. A viagem é temporária, em contraposição à viagem permanente feita pelo andarilho e pelo nômade;

2. É voluntária, em contraposição à viagem obrigatória do exilado e do refugiado;

3. É uma viagem de ida e de volta, em contraposição à viagem só de ida do migrante;

4. É relativamente longa, em contraposição à viagem da pessoa que faz uma excursão ou dá um passeio rápido e curto;

5. Não é recorrente, em contraposição às repetidas viagens das pessoas que têm casa na praia, no campo ou na montanha;

6. Não é instrumental, em contraposição à viagem como um meio para outro fim da pessoa que viaja a trabalho, do caixeiro-viajante ou vendedor itinerante ou de romeiros e peregrinos;

7. É feita em busca de novidade e mudança, em contraposição à viagem com outros propósitos, como o estudo.

Levantados esses pontos, apresenta-se aqui apenas a definição da Organização Mundial do Turismo (OMT), que considera o turismo como "o deslocamento para fora do local de residência por período superior a 24 horas e inferior a 60 dias, motivado por razões nãoeconômicas". Existem muitas outras definições de turismo, de diversos autores e órgãos interessados em dados turísticos, mas todas consideram o mínimo descrito na definição $\operatorname{acima}^{16}$.

É importante compreender que o turismo não deve ser percebido de forma isolada, mas sim como um sistema complexo, no qual devem ser consideradas diversas variáveis, tais quais a motivação para a viagem, a decisão pelo destino, o deslocamento entre a origem e o destino, o tempo de permanência na área receptora, a infraestrutura turística e complementar, além de variáveis contidas no ambiente natural, cultural, social e econômico, e nas funções de organização e operacionalização (BENI, 1998).

Devido a essa complexidade e à movimentação econômica gerada pelo turismo, aliadas ao seu grande crescimento, a OMT classificou essa atividade como um dos mais notáveis fenômenos econômicos e sociais do século passado.

O turismo, enquanto atividade organizada, não é um fenômeno recente. Na verdade, desenvolve-se há bastante tempo, embora, durante seu percurso, o turismo tenha sofrido diversos tropeços e tenha precisado de muitos ajustes. Como descrevem Rejowski e Solha (2002: 112):

\footnotetext{
${ }^{16}$ Para uma síntese dessa discussão, consultar DIAS e AGUIAR, 2002. Para a definição de turista, consultar ROSS, 2001.
} 
[O] adolescente e irresponsável turismo errou e acertou aventurando-se por vários caminhos. Com cerca de 150 anos de existência, está chegando à maturidade. A partir de então, espera-se que se comporte com mais conhecimento, responsabilidade e habilidade, perdurando no tempo e redirecionando o seu ciclo de desenvolvimento com equilíbrio.

No Brasil, a atividade turística passou por diversos períodos (SOLHA, 2002: 118), dentre os quais as décadas de 50 e 60, como um período "de ampliação e melhoria da infra-estrutura de transportes e turística até a organização da atividade por associações e a elaboração de políticas públicas", seguido por um "período de intenso crescimento e das perspectivas otimistas à estagnação e decadência" entre os anos de 1970 a 1989, e uma retomada, de 1990 a 2000, com o "crescimento do mercado interno aos grandes investimentos em vários e diferentes setores e da descoberta de novos segmentos de mercado".

Numa perspectiva histórica, vê-se que "(...) fabricou-se a identidade nacional em cima do carnaval, da mulata, do futebol. Então, tábula rasa, se fosse Brasil, teria que ter esses ingredientes em detrimento dos verdadeiros regionalismos e dos modos de vida representativos que ainda neles se apóiam" (YAZIGI, 1999: 23). Mais tarde, durante algum tempo, o Brasil tentou firmar-se como um destino de praia e sol.

Por volta dos anos 90 , houve no mundo inteiro um processo de reflexão sobre os produtos que estavam sendo ofertados e sobre a necessidade de se pensar em elementos que complementassem a oferta turística (SANTANA, 1998). Aos poucos, o país despertou para outros atrativos, com a inserção da cultura popular, da gastronomia e de conjuntos arquitetônicos históricos e religiosos. Além disso, privilegiado em termos de diversidade biológica, com biomas diversos, entre eles florestas tropicais com reconhecida riqueza natural (MMA, 2002), o país passou a utilizar-se desse potencial para o desenvolvimento do Ecoturismo e do Turismo de Aventura.

Desde 2003, ano de sua criação, o Ministério do Turismo (MTUR) tem o papel de "desenvolver o turismo como uma atividade econômica sustentável, com papel relevante na geração de empregos e divisas, proporcionando a inclusão social ${ }^{\prime 17}$ e, para isso, estabelece a cada quatro anos um Plano Nacional de Turismo (PNT). O PNT 2007-2010, denominado "Uma Viagem de Inclusão", tinha como objetivo (BRASIL, 2007):

${ }^{17}$ Fonte: página oficial do MTUR na internet: www.turismo.gov.br. Acesso: out./2010. 
[T]ransformar a atividade em um importante mecanismo de melhoria do Brasil e fazer do turismo um importante indutor da inclusão social. Uma inclusão que pode ser alcançada por duas vias: a da produção, por meio da criação de novos postos de trabalho, ocupação e renda, e a do consumo, com a absorção de novos turistas no mercado interno.

Infelizmente, o referido plano não conseguiu atingir nenhuma de suas metas no período em questão, conforme gráficos disponibilizados na página oficial do governo ${ }^{18}$.

Há discussões sobre como o turismo deve ser percebido ou analisado. Lea Davidson (2001) defende, por exemplo, que a sua definição como um setor seria incorreta, minimizando-o. 0 autor argumenta que (LEA DAVIDSON, 2001: 51):

[o] turismo é um fenômeno socioeconômico que atua tanto como força motriz do progresso econômico quanto como força social. É muito mais que um setor. O turismo é mais propriamente uma "indústria" que afeta uma ampla gama de setores. O turismo não diz respeito apenas a empreendimentos ou governos, mas a pessoas. $\mathrm{O}$ apoio ao crescimento e ao desenvolvimento racional do turismo deve ser considerado no âmbito desse contexto mais amplo.

A existência de visitantes em uma determinada localidade, todavia, nem sempre resulta em benefícios, principalmente, a médio e longo prazo. Para que isso se concretize, é necessário investir no planejamento da atividade - o que leva tempo e necessita de recursos. No contexto brasileiro, a falta de consciência política inviabiliza, ainda hoje, investimentos de longo prazo. Por esse, entre outros motivos, pouco se planejou o turismo no Brasil durante muitos anos. Os dados do turismo brasileiro demonstram esse descaso (DIAS E AGUIAR, 2002). De fato, em muitas cidades brasileiras, bem como em muitas Unidades de Conservação (UC), e em praias ou em outros locais com potencial turístico, só existia - e em alguns locais continua a existir - a presença de visitantes, sem que haja uma infraestrutura turística ${ }^{19}$ ou serviços turísticos ${ }^{20}$ que possibilitem as suas permanências.

Embora comumente se pense que o Brasil é um grande destino turístico mundial, a realidade atual é bem diferente: o país está muito aquém do que poderia em termos de desenvolvimento turístico, ainda mais em se considerando a diversidade de atrativos, o

\footnotetext{
${ }^{18}$ Fonte: www.indicadores.turismo.gov.br. Acesso: out./2010.

19 "Quando falamos em infra-estrutura turística, referimo-nos ao conjunto de bens e serviços que estão à disposição do turista, como parte integrante, fundamental ou acessória, do fenômeno turístico. A infraestrutura turística de um núcleo abrange a infra-estrutura de acesso, a infra-estrutura urbana básica, os equipamentos e serviços turísticos, os equipamentos e serviços de apoio e os recursos turísticos" (BARRETO, 2002: 48).

20 "Serviços turísticos são aqueles serviços que justificam sua existência quase que exclusivamente em virtude do turismo" (idem).
} 
tamanho do país e a beleza de muitas das suas regiões. A distância dos principais centros emissores mundiais, a falta de promoção turística, o custo dos produtos turísticos ${ }^{21}$, a carência em infraestrutura geral, a desigualdade social e consequente violência pública são apenas algumas das dificuldades com que os profissionais de turismo têm que lidar.

Em 2007, as Américas registraram 142.494 milhões de chegadas de turistas internacionais, das quais o Brasil colaborou com apenas 3,5\% (OMT, 2008). Porém, apesar de o Brasil continuar apresentando números inexpressivos no cenário turístico mundial, com uma variação nas taxas de crescimento anual passando por um decréscimo de 6,4\%, entre 2005 e 2006, e um inexpressivo crescimento, entre 2006 e 2007 (0,2\%), o turismo ainda continua a ser visto como uma possibilidade de mudanças sociais. Segundo os dados apresentados abaixo (OMT, 2008), o turismo:

[...]se ha convertido en uno de los principales agentes del comercio internacional. En la actualidad, los ingresos de exportación generados por el turismo internacional ocupan la cuarta posición, después de los combustibles, los productos químicos y los productos automotrices, mientras que en muchos países en desarrollo el turismo es la primera categoría de exportación. Al paso que representa una de las principales fuentes de ingresos para muchos países en desarrollo, crea el empleo y las oportunidades de desarrollo que tanto se necesitan.

Cifras clave:

- De 1950 a 2007, las llegadas de turistas internacionales aumentaron de 25 millones a 903 millones.

- Los ingresos totales generados por estas llegadas (ingresos por turismo internacional y transporte de pasajeros) se incrementaron a un ritmo similar, impulsando el crecimiento de la economía mundial, al alcanzar más de 1 billón de dólares de EE.UU. en 2007, lo que corresponde a casi 3.000 millones de dólares al día.

- Si bien en 1950, los 15 primeros destinos turísticos representaron el 88 \% las llegadas internacionales, em 1970 el porcentaje cayó al 75 \% y al 57 \% en 2007, lo que refleja el surgimiento de nuevos destinos, muchos de ellos en países en desarrollo.

Em 2010, O Brasil contabilizou 5.161.379 chegadas de turistas pelas mais diversas vias de acesso, sendo os meses de janeiro e fevereiro os mais procurados. Desses turistas, aproximadamente $46 \%$ tinham residência permanente na América do Sul (2.384.186), 31\% na Europa (1.614.864) e 15\% na América do Norte (773.181) (BRASIL, 2011).

A escolha do Brasil para sediar a Copa do Mundo de Futebol, em 2014, trouxe à mídia parte dessa problemática e mostrou como o país é carente de infraestrutura turística. As exigências da FIFA deixaram claro ao governo e aos cidadãos que recepcionar e acomodar

\footnotetext{
${ }^{21}$ Embora difícil de conceituar, o produto turístico pode ser percebido como um conjunto formado por três partes principais: os atrativos, a infraestrutura e a viabilidade de acesso, ao qual, necessariamente estarão associadas uma demanda e a sua própria oferta (ver DIAS E AGUIAR, 2002).
} 
pessoas exige preparo e extrapola a simples existência de locais bonitos. É necessário transporte público, segurança, cuidado com o meio ambiente, equipamentos de hospedagem de qualidade, capacitação profissional, opções de entretenimento, entre tantos outros itens muitas vezes menosprezados no país. Este evento esportivo atraiu para o Brasil as atenções de todo o mundo e, certamente, a quantidade de pessoas que participarão do mundial será imensa. No Brasil, todos precisam estar cientes de que essa oportunidade tanto pode gerar muitos benefícios - colocando, definitivamente, o país no mercado turístico internacional - como pode reverter-se numa experiência malfadada caso o Brasil não consiga preparar-se a tempo.

Certamente, há muito o que se discutir em termos de dificuldades relacionadas ao desenvolvimento do turismo no Brasil, mas, para este trabalho, será destacada a questão da diversificação da oferta como um fator importante para o incremento da atividade turística, sendo o patrimônio arqueológico passível de utilização em favor dessa diversificação. 


\title{
CAPÍtULo II - TURISMO ARQUEOLÓgICO
}

\begin{abstract}
Cualquier entidad arqueológica antes de su activación patrimonial son sólo piedras y artefactos. Después serán patrimonio institucional de un pueblo. Más tarde, con la divulgación y la vinculación identitaria, se convierte en patrimonio público. Luego, con su entrada

en el mercado podría ser patrimonio turístico. Las experiencias a escala mundial, como son los casos de México, Egipto o Grecia, muestran que hasta la fecha la explotación comercial es la opción que más asegura, junto con la aplicación de un Plan de Manejo vigilado y monitoreado, la rehabilitación y conservación de los bienes culturales.
\end{abstract}

(RATTO, s/d)

Este capítulo aborda o Turismo Arqueológico ou Arqueoturismo. Não foram feitas grandes incursões nos exemplos nacionais ou internacionais, nem análises a partir dos mesmos, porque se julgou que não seria fundamental para o encaminhamento deste trabalho. Optouse por focar a questão do planejamento dos produtos arqueoturísticos e sintetizar os materiais nacionais e internacionais disponíveis que abordassem Melhores Práticas para atividade ou, de forma mais abrangente, Turismo Cultural, Ecoturismo, planejamento turístico etc. Além disso, fez-se um esforço em reunir princípios norteadores que devem ser considerados por todos os envolvidos com o Turismo Arqueológico. Na última parte, apresentou-se a Interpretação do Patrimônio e destacou-se a importância do seu uso no planejamento da comunicação com os visitantes de locais com patrimônio culturais. 
Em todo o mundo, existem diversos exemplos de destinos turísticos cujos atrativos são fundamentalmente arqueológicos. Da antiguidade do continente europeu, por exemplo, deriva um patrimônio arqueológico riquíssimo referente a diversos períodos, desde os primórdios da humanidade, como a gruta pré-histórica de Lascaux, na França, passando por épocas de grandes transformações no modo de vida da humanidade e, também, por épocas nas quais grandes disputas territoriais deixaram registros humanos de caráter singular, como as diversas ruínas de colônias gregas e do Império Romano, encontradas em diversos países europeus. Na América do Norte, o México destaca-se por possuir um grande acervo arqueológico, tanto em termos de cultura material, hoje encontrada em seus museus, quanto nos sítios arqueológicos com edificações surpreendentes, como os de Teotihuacan, Palenque e Chichen Itzá. Na América do Sul, o Peru talvez detenha o patrimônio arqueológico mais divulgado, destacando-se a cidade de Machu Picchu. No continente africano, considerado o "berço" da humanidade por possuir alguns dos sítios arqueológicos mais antigos do mundo, o Egito é, sem dúvida, a grande expressão da arqueologia. Em comum, os locais citados possuem monumentalidade. E é muito fácil transformar algo monumental em um atrativo para o turismo.

No território brasileiro, a ocorrência dos sítios arqueológicos não é óbvia, o quer dizer que não é possível prever com exatidão suas localizações. Existem áreas onde a ocorrência de vestígios é mais provável, mas, às vezes, os pesquisadores também são surpreendidos. É mais comum se encontrar sítios arqueológicos em áreas rurais ou de forte interligação com a natureza, devido à preservação dos mesmos, como os tantos sítios de Terra Preta na Amazônia e as pinturas rupestres no nordeste brasileiro. No entanto, novos estudos arqueológicos em áreas urbanas estão trazendo à tona inúmeros vestígios históricos antes desconhecidos (ZANETTINI, 2006).

Além disso, a grande extensão territorial brasileira proporciona vestígios arqueológicos muito variados em cada canto do país: pinturas rupestres são diferentes no nordeste ou no sul e o mesmo se dá com a cerâmica. Apesar da grande diversidade, os exemplos de atrativos arqueoturísticos reais ${ }^{22}$ no país são raros. Destaque-se que, os exemplos mais

\footnotetext{
${ }^{22} \mathrm{O}$ atrativo turístico é a matéria-prima (recursos naturais, sociais, culturais e tecnológicos) com a qual se pode planejar o turismo em determinado local. É aquilo que atrai o turista sozinho ou em combinação com outros. Pode ser classificados como atrativo real, se já estiver sendo utilizado turisticamente e se contar com
} 
significativos e, talvez, os melhores existentes no país em termos de infraestrutura para o turismo, são mantidos e viabilizados graças a empreendimentos privados e/ou fundações, como são os casos da (i) Serra da Capivara, no Piauí23, citada no capítulo anterior (Ilustração II.1), (ii) do Costão do Santinho, em Florianópolis, Santa Catarina ${ }^{24}$ (Ilustração II.2) e (iii) do Parque Histórico e Cultural Garcia d'Ávila, na Praia do Forte, Bahia ${ }^{25}$ (Ilustração II.3). Outro exemplo que merece destaque é o das ruínas das Missões Jesuíticas do sul do Brasil. São quatro ruínas, São Miguel, São Lourenço Mártir, São João Batista e São Nicolau, que atualmente fazem parte de roteiros turísticos do Rio Grande do Sul, em conjunto com museus e outros sitos arqueológicos (BIESEK, 2004). Neste contexto, destaca-se o município de São Miguel das Missões, onde, entre outras atrações, encontra-se a Redução de São Miguel Arcanjo ${ }^{26}$, reconhecida pela UNESCO, em 1993, como Patrimônio Cultural da Humanidade. Nesse local, realiza-se um espetáculo de Luz e Som, onde a história da região missioneira é contada (cf. BIESEK, 2004). Para garantir a preservação das ruínas e estimular e promover o desenvolvimento econômico, social e cultural das localidades envolvidas, foi criada, em 2001, a Fundação dos Municípios das Missões ${ }^{27}$.

infraestrutura e equipamentos para o atendimento dos turistas, ou em atrativo potencial, quando, mesmo possuindo elevado grau de atratividade, ainda não estiver inserido no mercado turístico e não possuir infraestrutura adequada para o atendimento (RUSCHMANN, 2001).

23 "O maior atrativo do Parque é a densidade e diversidade de sítios arqueológicos portadores de pinturas e gravuras rupestres pré-históricas. É um verdadeiro Parque Arqueológico com um patrimônio cultural de tal riqueza que determinou sua inclusão na Lista do Patrimônio Mundial pela UNESCO". Fonte: http://www.fumdham.org.br/turismo.asp. Colhido em 25/03/2010.

24 "Museu Arqueológico ao Ar Livre - O museu foi inaugurado em dezembro de 1997, sendo o primeiro do gênero no país. Além de expor informações sobre a arqueologia local, este museu possui o maior número de inscrições rupestres do Morro das Aranhas com estrutura de preservação e visitação" e "Museu dos Brunidores - Inaugurado em junho de 2002, este sítio arqueológico apresenta uma grande variedade de rochas utilizadas no passado para a confecção de instrumentos e artefatos líticos, entre eles, os zoólitos (animais de pedra), pontas de lanças, machados, batedores $e$ pesos para redes de pesca". Fonte: http://www.costao.com.br/EcologySitios.aspx. Colhido em 25/03/2010

25 "Um complexo que compreende as ruínas da Casa da Torre (Castelo Garcia D'Ávila) e a área em seu entorno, um sítio arqueológico e um Centro de Visitação com $1.700 \mathrm{~m}^{2}$, formado por um amplo salão onde está exposta a maquete (modelo reduzido) do Castelo e espaços onde estão instaladas salas para exposições históricas e arqueológicas, loja, salão para áudio visual, belvedere e centro administrativo". Fonte: http://www.fgd.org.br . Colhido em 25/03/2010.

${ }^{26}$ Fonte: http://www.saomiguel-rs.com.br/Turismo/. Colhido em: 28/10/2010.

${ }^{27}$ Fonte: http://www.rotamissoes.com.br/_portugues/fundacaoComponentes.php. Colhido em: 28/10/2010. 

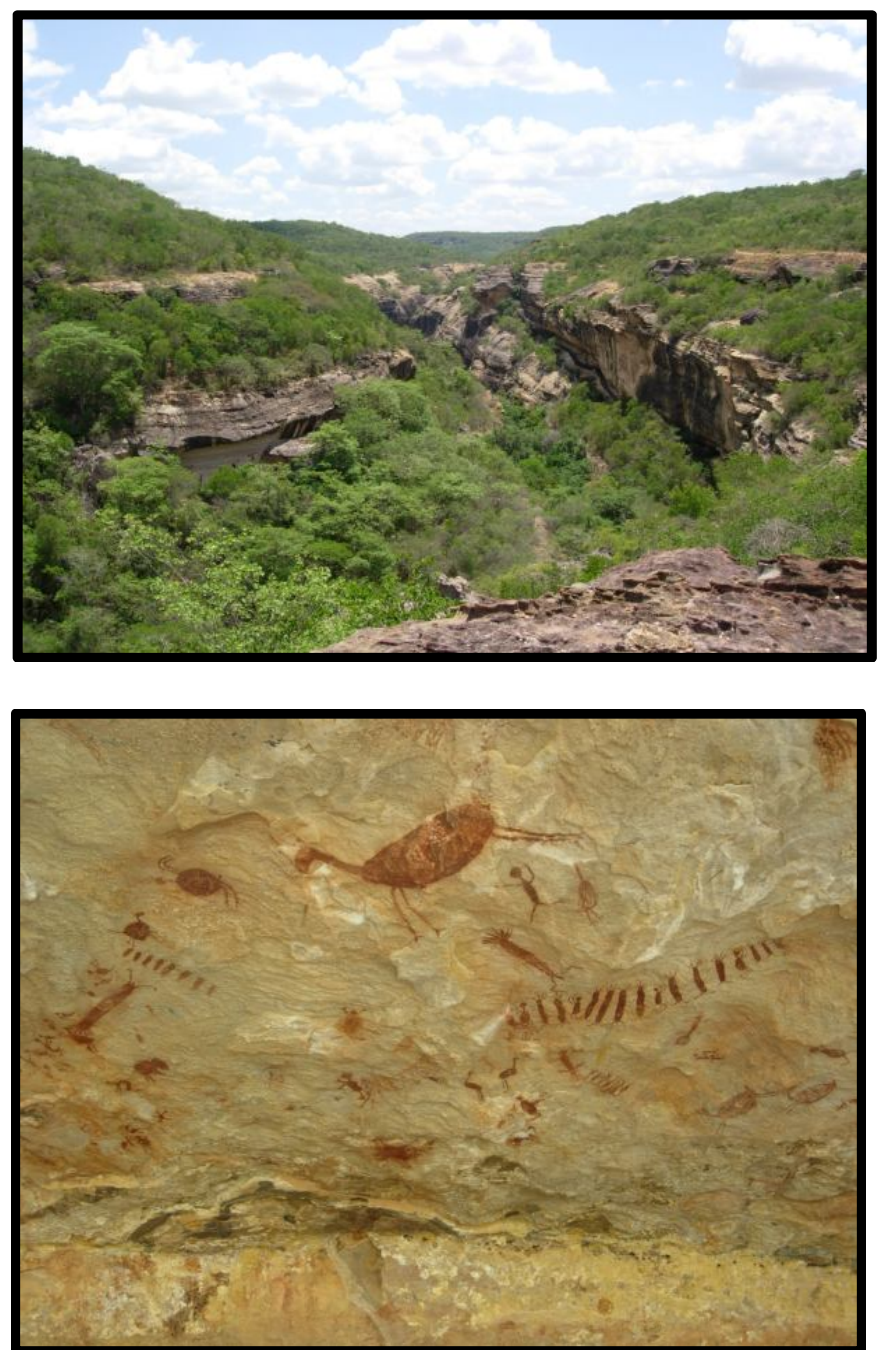

Ilustração II.1: Serra da Capivara. São Raimundo Nonato, Piauí (FotografiAs: Adriana Guimarães, 2006).
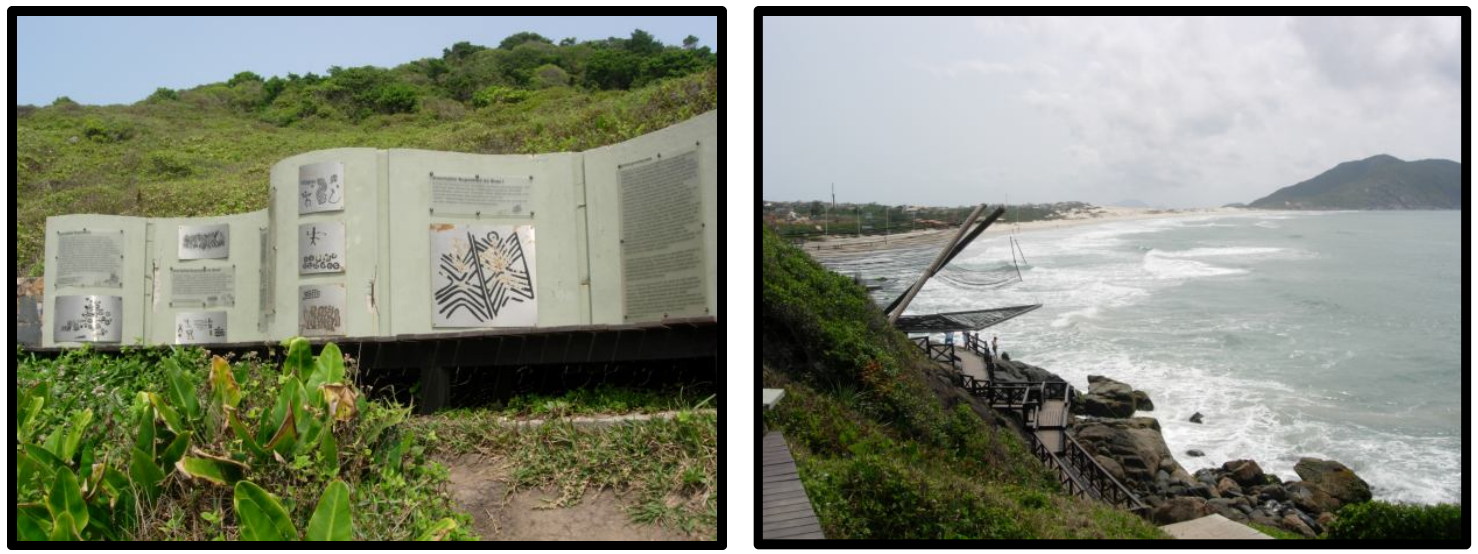

Ilustração II.2: Costão do Santinho. Florianópolis, Santa Catarina (FotogRAFIAS: Adriana Guimarães, 2007). 

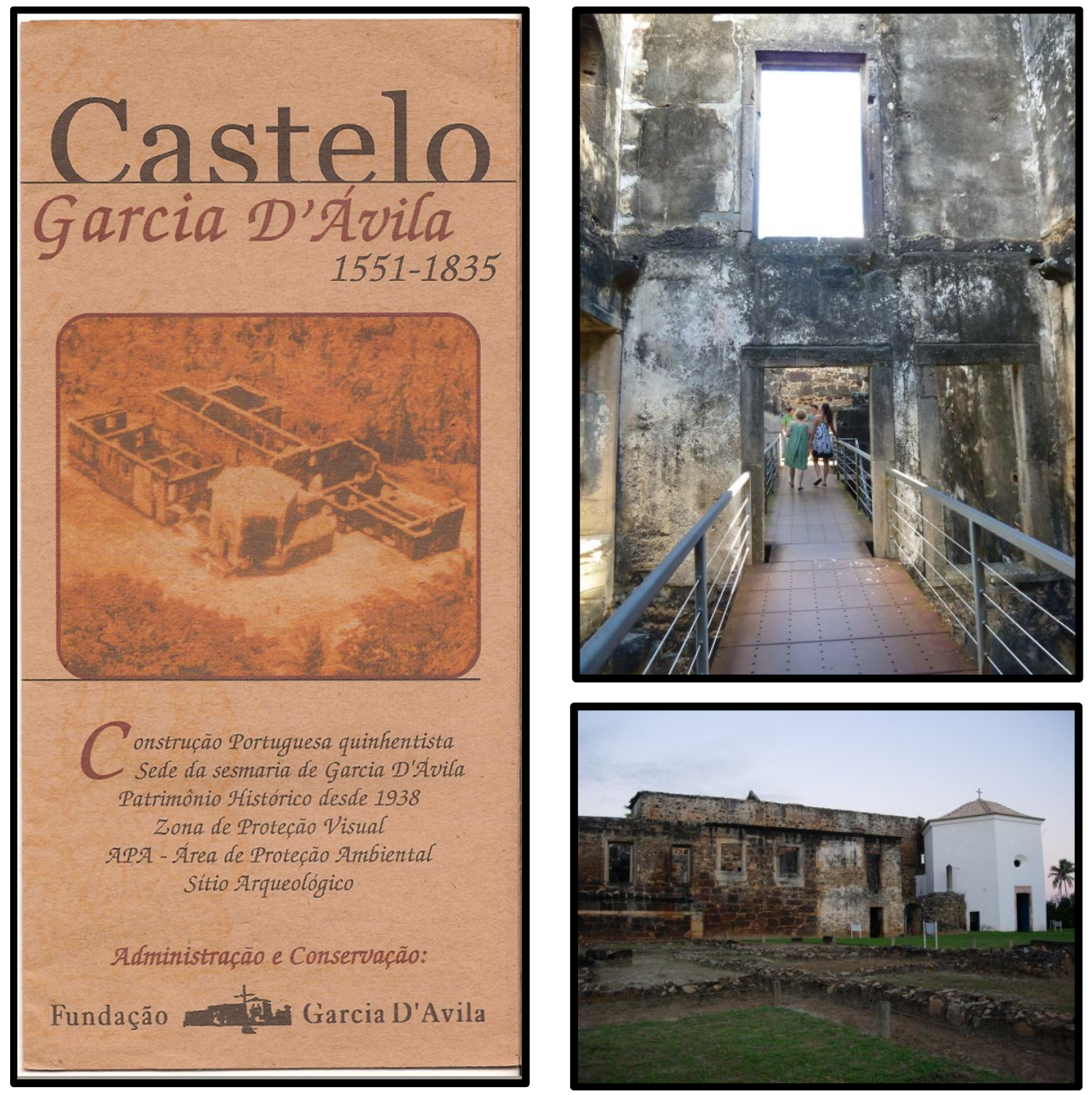

Ilustração II.3: Panfleto (Fundação Garcia D’Ávila) e Castelo Garcia D’Ávila, Praia do Forte, BA (FotografiAs: Adriana Guimarães).

Andrade (2007), em seu trabalho sobre Turismo e Arqueologia na Amazônia, produziu uma tabela com base em informações obtidas em diversas fontes, de fontes científicas até reportagens jornalísticas, roteiros e propagandas de turismo, e chegou a um número de 152 (cento e cinquenta e dois) sítios arqueológicos expostos à visitação pública em todas as regiões brasileiras. Segundo a autora, estes sítios encontram-se em três situações distintas: "1) organizado de maneira sustentável; 2) não organizado, porém com a preocupação para um planejamento; 3) não planejado e prejudicial". A quantidade é surpreendente. Porém, a análise desses dados pode levantar pelo menos um dado, aqui visto como bastante relevante, que precisa ser debatido, sem desmerecer o levantamento realizado pela autora, 
mas com o intuito de contribuir para a compreensão da realidade do arqueoturismo no Brasil: $40 \%$ (quarenta) dos sítios listados pelo trabalho são sítios históricos, quase todos fortes ou fortalezas.

Sem aceitar prontamente que Turismo Histórico e Turismo Arqueológico são a mesma coisa, julga-se necessário impor um limite à classificação de sítios históricos como sítios arqueológicos. Embora também se utilize de fontes históricas, a Arqueologia Histórica só se caracteriza como tal se houver a pesquisa arqueológica dos vestígios materiais relacionados àquele objeto de estudo. Isso está de acordo com a definição do ICOMOS, na Carta para Proteção e Gestão do Patrimônio Arqueológico (1990), artigo 1:

The "archaeological heritage" is that part of the material heritage in respect of which archaeological methods provide primary information. It comprises all vestiges of human existence and consists of places relating to all manifestations of human activity, abandoned structures, and remains of all kinds (including subterranean and underwater sites), together with all the portable cultural material associated with them (ICOMOS, 1990) ${ }^{28}$.

Isso não quer dizer que sítios históricos estejam dispensados da pesquisa arqueológica quando do seu estudo ou restauração. Na visão desta tese, é a forma de obtenção dos dados que justifica a diferenciação entre Arqueologia e História, que aqui são percebidas como ciências diferentes.

Andrade esclarece, no entanto, que foram considerados arqueoturísticos apenas os sítios históricos que "não mantêm mais a função para a qual foram construídos transformando-se, em muitos casos, em centros de lazer e cultura e algumas vezes abrigando museus" (ANDRADE, 2007: 34). Pensa-se que essa avaliação é difícil de ser realizada quando se fala em conjuntos de casarões históricos existentes nas cidades mais antigas do Brasil, como é o caso dos existentes nas cidades de Ouro Preto, Mariana e Congonhas, em Minas Gerais, no Pelourinho, em Salvador, na Bahia, no centro histórico de Olinda, em Pernambuco, no centro de São Luiz, no Maranhão, e, até mesmo, no centro das cidades de São Paulo e de Santos, em São Paulo e no Rio de Janeiro. Nesses locais, os usos atuais dos prédios históricos são diversos e, na maioria dos casos, distintos daqueles a que inicialmente estiveram destinados,

\footnotetext{
${ }^{28}$ Define-se patrimônio arqueológico como sendo a parte do patrimônio material sobre a qual os métodos arqueológicos fornecem informações primárias. Ele engloba todos os vestígios da existência humana e é constituído de lugares relacionados a todas as manifestações da atividade humana, tais quais estruturas abandonadas e vestígios de todos os tipos (incluindo sítios subterrâneos e subaquáticos), além de todo o material cultural móvel associados a tais lugares [Tradução: Luciana M. Guimarães].
} 
abrigando museus, ONGs, restaurantes, sorveterias, lojas ou escritórios. Dessa forma, considera-se que, naquele trabalho (i.e. ANDRADE, 2007), a listagem precisaria tomar outra dimensão, sendo necessário acrescentar os exemplos mencionados acima e tantos outros espalhados pelo país. Desta forma, existiriam muito mais sítios arqueológicos abertos à visitação pública no país e a listagem supracitada seria alterada significativamente. Ou terse-ia, provavelmente, $40 \%$ (quarenta por cento) a menos de sítios naquela listagem, o que seria mais coerente, já que nenhum desses locais é, e nem deveria ser, anunciado turisticamente como grande atrativo arqueoturístico a ser conhecido. Para avaliar a pertinência dessa inserção, opina-se que seria necessário olhar em quantos destes sítios históricos citados houve, de fato, pesquisa arqueológica. Para refletir sobre um dos locais históricos citados por Andrade, é incoerente convidar o público para vivenciar a arqueologia no Forte Santo Antônio da Barra, em Salvador, no estado da Bahia, mais conhecido como Farol da Barra. Mesmo sendo este o farol mais antigo do continente $(1698)^{29}$, todas as informações disponíveis sobre ele provêm de fontes históricas, sendo que até o momento nenhuma delas resulta de pesquisas arqueológicas.

De qualquer forma, é claro que há, no Brasil, um enorme potencial para o Turismo Arqueológico e que este vem sendo desperdiçado. Além dos sítios arqueológicos, o país conta com um rico acervo arqueológico guardado em museus que ainda é desconhecido, ainda mais considerando-se a abertura e/ou consolidação de diversas instituições museológicas no interior do país por conta da arqueologia de contrato (p.ex. o Museu de Arqueologia de Xingó - MAX, em Canindé de São Francisco/SE e o Museu de Arqueologia e Paleontologia de Araraquara, em Araraquara/SP). É urgente, portanto, que um novo olhar por parte do turismo e da arqueologia - seja lançado ao imenso patrimônio arqueológico nacional, o que significa organizar e planejar o seu uso público e estimular a interdisciplinaridade para garantir a qualidade e diversidade desse acesso.

Contudo, a falta de construções monumentais, como pirâmides e templos, e o paradigma da pouca antiguidade da ocupação do continente são argumentos para a falta de visibilidade desses bens. Esta condição interfere, de fato, no quão conhecido e apreciado é o patrimônio

\footnotetext{
29 Informação disponível no site Patrimônio Histórico de Salvador - um link entre presente e passado. Endereço: http://patrimoniodesalvador.wordpress.com/category/fortes-de-salvador/. Último acesso: fev./ 2012.
} 
arqueológico brasileiro. Porém, essa argumentação não é totalmente convincente. Mesmo que se considere que o patrimônio arqueológico brasileiro não seja, devido à falta de monumentalidade, atrativo aos turistas, ainda assim seria viável a sua exploração turística, com a criação de complexos arqueoturísticos. Nesse sentido, Pires (2000) lembra que " $a$ monumentalidade sem dúvida contribui para uma maior atratividade, mas se um bem assim caracterizado faz parte de um complexo, sua importância turística tende a aumentar".

Os profissionais envolvidos devem considerar o grau de atratividade ${ }^{30}$ dos recursos turísticos (RUSCHMANN, 1997) ao realizar o planejamento de destinações turísticas e ter em mente que mesmo os recursos com baixo poder de atração individual podem e devem ser incluídos no patrimônio turístico, complementando o produto final, tornando-o mais diversificado e, portanto, mais atraente.

Desse modo, a inserção de atrativos arqueológicos em roteiros turísticos, por exemplo, dependerá, obrigatoriamente, não apenas da matéria-prima à disposição, mas da criação de uma infraestrutura ${ }^{31}$ adequada, dotando o local de condições de utilização e aproveitamento pelos turistas. Por isso mesmo, eles não serão valorados apenas pela sua força atrativa, mas também pela sua qualidade (RUSCHMANN, 2001), que é fator decisivo para a sua sustentação no mercado.

${ }^{30}$ Escala hierárquica para os atrativos turísticos (RUSCHMANN, 2001: 143):

"Para os recursos passíveis de aproveitamento turístico, recomenda-se uma avaliação, ou seja, uma análise crítica das atrações, a fim de estabelecer seu interesse turístico sobre bases objetivas e comparáveis entre si, assinalando sua correspondência hierárquica, que pode se situar nos seguintes níveis (Cicatur 1977):

Hierarquia 3: Atração excepcional, altamente significativa para o mercado turístico internacional e capaz de, por si só, motivar uma importante corrente de turistas.

Hierarquia 2: Atração com aspectos excepcionais em um país, capaz de motivar uma corrente de turistas nacionais ou estrangeiros, por si só, ou em conjunto com outras atrações.

Hierarquia 1: Atração com alguns aspectos chamativos, capaz de interessar os turistas que vieram de longe para a região por outras motivações turísticas, ou capaz de motivar correntes turísticas locais. Hierarquia 0: Atração sem méritos suficientes para ser incluída nas hierarquias anteriores, que, porém, faz parte do patrimônio turístico como elemento que pode complementar outros de maior interesse no desenvolvimento de complexos turísticos".

31 "Quando falamos em infra-estrutura turística, referimo-nos ao conjunto de bens e serviços que estão à disposição do turista, como parte integrante, fundamental ou acessória, do fenômeno turístico. A infraestrutura turística de um núcleo abrange a infra-estrutura de acesso, a infra-estrutura urbana básica, os equipamentos e serviços turísticos, os equipamentos e serviços de apoio e os recursos turísticos" (BARRETO, 2002: 48) 
A avaliação da qualidade dos produtos turísticos é diferente da de produtos tradicionais, porque eles possuem singularidades ${ }^{32}$ que obrigam o turista a avaliá-los segundo os equipamentos e materiais utilizados, os procedimentos adotados e a equipe envolvida. Como detalha Christou (2005: 11):

Although heritage tourists spend money, time and other resources on a trip or a visit, there is no tangible return on their investment. What tourists receive from their investment is an experience that provides mainly psychological benefits (Kozak, 2001). Hence, the heritage tourist product is not a measurable or quantifiable good. Rather, it is an experience or un point de vue ('a point of view') (Mathieson and Wall, 1982). This experience is based on the subjective personal reactions and feelings experienced by consumers when they consume a tourism service (Otto and Ritchie, 1996). Thus, although service quality is important from the perspective of the heritage tourism business, the experience that tourists or visitors derive from interacting with the service is also an important factor. Happy and satisfied customers are more likely to return, and more likely to say positive things about the service they have experienced ${ }^{33} .^{34}$

Swarbrooke e Horner (2002: 307) concordam e complementam: "em razão da natureza complexa do turismo, a qualidade do produto pode ser vista como um quebra-cabeças, com inúmeras peças igualmente importantes, mas de diferentes tamanhos, devendo todas se encaixarem perfeitamente entre si para satisfazer o turista". Para que esse quebra-cabeça fique bem montado, é inadmissível pensar que o Turismo Arqueológico prescinda de planejamento. Ao contrário, ele é absolutamente necessário, pois consiste em ordenar as

\footnotetext{
${ }^{32}$ As singularidades de um produto turístico, segundo Kripendorf (1980), são: bem de consumo abstrato, isto é, imaterial e intangível; coincidência espacial e temporal; necessidade da presença da clientela no local da produção; impossibilidade de estocagem; serviços prestados de forma irregular; interdependência entre seus componentes; sazonalidade; a instabilidade da demanda; demanda heterogênea (muitos fatores interferem na opção por um destino, entre eles fatores econômicos, sociais, culturais, políticos e legais); produto estático (impossível mudar sua localização e a quantidade de uma atração) e uma acentuada concorrência entre si. Além da rigidez (a oferta não pode se expandir em curto espaço de tempo, para isso é preciso tempo e novos investimentos), citada por Lemos (1997), e de uma grande capacidade de gerar outras atividades econômicas.

${ }^{33}$ Embora os arqueoturistas invistam dinheiro, tempo e outros recursos em uma viagem ou visita, não há nenhum retorno tangível de seus investimentos. O que os turistas colhem de seus investimentos é uma experiência que, em sua maior parte, traz-Ihes benefícios psicológicos (Kozak, 2001). Deste modo, o produto do turismo patrimonial não é um bem mensurável ou quantificável. Ao contrário, constitui-se em uma experiência ou un point de vue ("um ponto de vista") (Mathieson and Wall, 1982). Esta experiência baseia-se em reações e sentimentos subjetivos e pessoais experienciados pelos consumidores ao usufruírem de um serviço turístico (Otto and Ritchie, 1996). Portanto, apesar da qualidade do serviço ser importante, partindo-se da perspectiva do negócio ou comércio do turismo patrimonial, a experiência que turistas e visitantes ganham ao interagirem com o serviço constitui-se, também, em um fator importante. Clientes felizes e satisfeitos tendem, mais frequentemente, a retornar e a dizer mais coisas positivas sobre o serviço que experienciaram [Tradução: Luciana M. Guimarães].

${ }^{34}$ Bibliografia na citação: *Kozak, M. (2001). Comparative assessment of tourist satisfaction with destinations across two nationalities. Tourism Management 22(4): 391-401. *Mathieson, A. and Wall, G. (1982). Tourism: Economic, Physical and Social Impacts. London: Longman. *Otto, J. E. and Ritchie, J. R. B. (1996). The service experience in tourism. Tourism Management 17(3): 165-174.
} 
ações do homem sobre o território, direcionando adequadamente a construção de equipamentos e facilidades e evitando efeitos negativos que possam reduzir ou destruir a atratividade dos recursos (RUSCHMANN, 2001). Além disso, o planejamento turístico também promove benefícios e reduz os custos das atividades vinculadas (IRVING et al., 2005).

O desenvolvimento da atividade turística sem um planejamento adequado - incluindo o envolvimento de profissionais das mais diversas áreas e das comunidades locais - pode degradar o ambiente, acarretando a diminuição dos benefícios inicialmente obtidos e o enfraquecimento da competitividade, o que, por sua vez, resulta na perda de visitantes para outras regiões (DIASE AGUIAR, 2002).

\section{1. Analisando as bases para o Planejamento do Turismo Arqueológico.}

Sendo a arqueologia um aspecto da cultura, a caracterização imediata que se faz é a do Turismo Arqueológico como um desdobramento do Turismo Cultural (BENI, 2001; SCATAMACCHIA, 2005) que, por sua vez, é detalhado pelo MTur (BRASIL, 2008: 13) da seguinte maneira:

Cultura e turismo configuram, em suas diversas combinações, um segmento denominado Turismo Cultural - que se materializa quando o turista é motivado a se deslocar especialmente com a finalidade de vivenciar aspectos e situações que podem ser considerados particularidades da cultura.

No entanto, definir Turismo Cultural não é tarefa simples, como é possível perceber no texto a seguir (UPSTATE INSTITUTE, 2010: 05):

What is "cultural tourism"? This is not an easy question to answer as one will quickly discover that the term has been defined in a variety of ways by different governments, industry organizations and academics around the world. (...)

(...) In short, the definitions of "cultural tourism" themselves vary considerably across "cultures" (nation states, regions, and organizations). Clearly no single definition is the best or correct, and each definition merely reflects what is considered "cultural" and worth presenting to 
"outsiders" by the local population. Indeed, the promotion of "cultural tourism" may be simultaneously the processes of seeing "the other" and self-discovery".

Pérez (2009: 109) aprofunda um pouco essa discussão:

Mas sem cair na tentação de considerar todo tipo de turismo como "turismo cultural", cabe perguntarmo-nos qual o sentido de "turismo cultural". Segundo a noção sociológica do conceito de cultura, será que é igual o turismo na cultura que a cultura no turismo? Pois bem, a semântica leva-nos a observar como o turismo cultural é considerado de formas diversas: actividade, experiência, formato do produto turístico, motivação ou factor chave para a viagem e/ou forma de realizar a actividade cultural. Num sentido mais restrito o turismo cultural seria um tipo de viagem por motivos unicamente culturais e educativos, uma definição que também apresenta os seus problemas e que não chega a ser consensual. De acordo com Bonink e Richards (1992) duas são as abordagens fundamentais para entender o turismo cultural:

a) A perspectiva dos lugares e dos monumentos. Implica descrever os tipos de atracções visitadas e pensar a cultura como um simples produto. Desde o ponto de vista da estratégia de investigação a seguir, esta seria fundamentalmente quantitativa e focaria as actividades e as motivações dos turistas culturais.

b) A perspectiva conceptual questiona os porquês e como as pessoas vêem e praticam turismo cultural. Sublinha mais os sentidos, as práticas discursivas, os significados e as experiências. Nesta óptica, o importante seriam os princípios e as formas de fazer turismo, e não tanto os produtos. Portanto, ao nível de investigação implica uma abordagem mais qualitativa.

No nosso ponto de vista, a primeira perspectiva é redutora, mas quando se cruzam as duas perspectivas, as abordagens do turismo cultural podem ser múltiplas. (...)

Neste trabalho, sustenta-se que essas múltiplas abordagens devem ser buscadas ao se planejar o Turismo Arqueológico no Brasil, acreditando que elas auxiliarão os interessados em seu planejamento a se desgarrarem de abordagens tradicionais, libertando-os para atuar com mais criatividade no desenvolvimento de produtos arqueoturísticos. Por isso, embora propondo atrativos arqueoturísticos, este trabalho aborda também as práticas discursivas e as experiências que podem ser obtidas na prática do Turismo Arqueológico, de acordo raciocínio anterior (PERÉZ, 2009), através da utilização da Interpretação Patrimonial, como será apresentado mais adiante. Nessa direção, concorda-se com a ideia de que o Turismo Cultural, embora esteja cada vez mais convertido em produção e consumo de bens e produtos culturais, deva extrapolar os componentes da oferta, adquirindo uma marca experiencial no contato dos turistas com o patrimônio cultural (GONÇALVES, 2009).

35 O que é o "Turismo Cultural”? Esta não é uma questão fácil de ser respondida, já que se constatará, rapidamente, que o termo foi definido de maneiras diversas por diferentes governos, organizações de setores distintos e por acadêmicos ao redor do mundo. (...) Em resumo, as definições de "Turismo Cultural" variam consideravelmente entre diferentes culturas (nações, regiões e organizações). Obviamente, nenhuma definição em si é melhor ou mais correta. Cada definição reflete, meramente, o que é considerado "cultural" e digno de ser apresentado pela população local a "pessoas de fora". De fato, a promoção do "Turismo Cultural" pode ser, simultaneamente, tanto o processo de enxergar "o outro" como o de auto-descoberta [Tradução: Luciana M. Guimarães]. 
A problemática das diferentes conceituações de Turismo Cultural vem sendo discutida na literatura (CARneiro et al., 2010; Köhler e Durand, 2007; Peréz, 2009; Moreira, 2008) e em eventos (UPSTATE INSTITUTE, 2010), alternando-se entre visões a partir da oferta ou da demanda do mercado. Porém, não se pode esquecer que alguns turistas visitam atrativos culturais em roteiros com outra motivação principal (CARNEIRO et al., 2010; BARRETO E REJOWSKI, 2009) e, portanto, encaixam-se em perfis diferenciados.

Tanto o Turismo Cultural quanto o Turismo Arqueológico são segmentos turísticos. Por isso, considera-se que mais conveniente do que simplesmente definir Turismo Arqueológico como Turismo Cultural, é discutir o sentido de segmentar o mercado turístico, entendendo as implicações dessas escolhas.

A segmentação, para a atividade turística, é um conceito importante porque implica "identificar e agrupar grupos distintos de compradores que podem exigir produtos e/ou compostos de marketing separados" (KOTLER, 1996).

Embora a classificação dos diversos tipos de turismo tenha variado bastante da década de setenta até os dias de hoje (BARRETo e ReJOWSKI, 2009), genericamente, constata-se que a segmentação turística pode ocorrer segundo a demanda (p. ex. tipo de turistas que procuram por: locais a curta ou longa distância das suas residências, em áreas urbanas ou rurais, de clima quente ou frio, pequenas e médias cidades ou grandes metrópoles) ou segundo a oferta (p. ex. o que o destino pode oferecer como atrativos e produtos, que define o tipo de turismo a ser realizado: de praia, de montanha, de verão, de inverno, marítimo, fluvial, urbano, rural). O mercado também poderá ser segmentado a partir de variáveis como a idade (i. e. turismo infantil, juvenil, de terceira idade), o sexo (p. ex. masculino, feminino, LGBT), o tamanho de família (p. ex. turismo individual, de casais, de grupos familiares), o ciclo de vida da família (i.e. jovem solteiro, jovem casado sem filhos, jovem com filho abaixo de seis anos, jovem casado com filho acima de seis anos, meia idade casado com filhos, meia idade casado sem filhos, idoso, solteiro), entre tantos outros fatores, dentre os quais a renda, a ocupação, o nível educacional, a religião, a raça, a classe social e o estilo de vida. Esses atributos, ou bases, para a segmentação podem ser ainda mais variados, incluindo os meios de transporte utilizados (caminhada, cicloturismo, áereo, 
náutico etc.), a duração de permanência (curta, média ou longa duração), o sentido do fluxo (emissivo ou receptivo), o grau de urbanização da destinação turística (turismo comunitário, de grandes metrópoles, de pequenas cidades etc.) entre outros, como exposto por Panosso Netto e Ansharah (2009).

Quanto mais subdivisões existirem dentro de um mesmo segmento, mais fácil será atender às exigências daquele grupo (DIAS E AGUIAR, 2002). Deste modo, existem dezenas de segmentos turísticos e segmentos dentro de segmentos. A segmentação, desse modo, não precisa ser algo estanque nem imutável, podendo, em muitos casos, ser múltipla (MIDDLETON, 1994). O próprio MTur (BRASIL, 2008) reconhece que a promoção de um produto, roteirizado ou não, com base em um segmento principal, não inviabiliza que vários outros segmentos possam ser trabalhados em outros tantos roteiros, a depender dos potenciais atrativos e do público que se queira buscar.

Desse modo, Costa (2006: 219) adverte:

$\mathrm{Na}$ atividade turística a segmentação deve ser implementada considerando todas as bases simultaneamente, como formas complementares e sobrepostas para caracterizar os segmentos de mercado. Em função da prioridade das informações para a escolha de segmentos-alvo deve ser considerado: 1ㅇ. - objetivo da viagem; 2ㅇ. - necessidades, motivações e benefícios buscados pelo consumidor; 3․ - comportamento do consumidor/características do uso do produto; 4‥ - perfil demográfico, econômico e geográfico e 5‥ - perfil psicográfico.

O Turismo Arqueológico pode, portanto, ser entendido como Turismo Cultural ou como um nicho de mercado especializado ${ }^{36}$, trabalhado como um tipo de turismo exótico ou partilhado com outras atividades turísticas. Note-se, no entanto, que, para cada uma das situações, o número de turistas envolvidos é diferenciado, bem como o são a especialização requerida e o nível dos serviços envolvidos. Dessa forma, também será diferente a maneira de posicionar tais produtos no mercado.

Para Tresseras (2004: 02) "el arqueoturismo o turismo arqueológico es una modalidad bajo la que se presentan propuestas y productos culturales y turísticos en los que la arqueología es el ingrediente principal".

36 "Nicho de mercado: um nicho, tradicionalmente, é um pequeno mercado composto por turistas com idiossincrasias ou gostos especiais, para os quais uma destinação é qualificada. (...) Um nicho de mercado, dessa forma, pode resultar de fatores intrínsecos ou de uma estratégia de promoção" (PANOSSO NETTO e ANSARAH, 2009: 25). 
Para Manzato (2005: 46), o Turismo Arqueológico é aquele que "consiste no processo decorrente do deslocamento e da permanência de visitantes a locais denominados sítios arqueológicos, onde são encontrados vestígios remanescentes de antigas sociedades, sejam elas pré-históricas ou históricas, passíveis de visitação terrestre e/ou aquática".

A prática desse segmento está, dessa maneira, condicionada à transformação do patrimônio arqueológico em um produto, para que o mesmo possa ser aproveitado turisticamente. Há, no entanto, quem defenda que o patrimônio deva ser apenas objeto de estudos ou quem venere o passado, esquecendo a importância científica dos objetos, não se importando em descontextualizá-los. Porém, é necessário evadir-se da ideia de que o patrimônio é, de qualquer forma, corrompido ao tornar-se público, ainda mais se consumido como um produto (SANTANA, 1998). É preciso ficar claro a todos os envolvidos que o produto turístico vislumbrado não é, em termos comerciais, o próprio patrimônio, mas sim as experiências e serviços que são criados em torno dele (PADRó WERNER, 2002).

Portanto, esclarece-se que o produto turístico, embora difícil de se conceituar, pode ser percebido como um conjunto formado por três partes principais: os atrativos, a infraestrutura (alojamento, alimentação, lazer etc.) e a viabilidade de acesso. Aos produtos turísticos, estarão necessariamente associadas uma demanda e a sua própria oferta (DIAS E AGUIAR, 2002), de tal forma que permitirão sua integração ao mercado turístico. Ou, nas palavras de Pérez (2009: 122):

Um produto, segundo as teorias do marketing, é algo que pode ser oferecido a um mercado para a sua atenção, aquisição, uso ou consumo. Ele satisfaz um desejo ou necessidade, gera benefícios e soluciona problemas ou necessidades reais ou imaginadas e inventadas.

O conceito de segmentação está, portanto, intrinsecamente atrelado ao conceito de marketing turístico, que é algo muito mais profundo do que apenas a promoção, como se percebe na descrição de Faulkner (2001: 314):

- O processo de identificação das necessidades e propensões do consumidor (ou, mais especificamente, de diferentes segmentos do público consumidor).

- O desenvolvimento ou a modificação do produto de acordo com a necessidade de mercadosalvo identificados.

- A criação de mecanismos para facilitar o conhecimento de, o interesse por e o acesso ao produto.

- A tradução disso tudo em vendas por meio de redes de distribuição, mecanismos de preços etc. 
Tendo em mente o estágio das pesquisas arqueológicas brasileiras e a sua pouca difusão, bem como o grau de atratividade geral do patrimônio arqueológico nacional, o planejamento da atividade arqueoturística deve estimular a criação de produtos com temáticas voltadas à arqueologia em níveis hierárquicos diferentes, idealizando utilizá-lo das três formas (patrimônio cultural), citadas por Pérez (2009: 163):

1. O património cultural como produto turístico autónomo, per se. Ex.: pirâmides de Egipto, Parque Nacional da Peneda-Gerês.

2. O património cultural associado num pacote turístico: viagem, atractivos lúdicos, visitas a elementos patrimoniais. Ex.: Paris, Barcelona...

3. O património cultural como mais-valia dos destinos turísticos: "Turismo de qualidade", "diversificação do produto turístico".

No Brasil, a diversidade de vestígios e das situações em que os mesmos podem ser encontrados, como já apontado anteriormente, indicam a possibilidade do aproveitamento turístico do patrimônio arqueológico dessas três formas. No cômputo geral, isso é muito importante, pois quanto mais segmentos são trabalhados por destino, novos produtos e serviços são criados e, com eles, mais empregos. O destino torna-se mais conhecido e, consequentemente, atrai um público maior. Para os estados e municípios, público maior reverte-se em mais vendas, ou seja, em aumento de receitas. Para a arqueologia, um público maior significa a possibilidade de que uma parcela significativa de pessoas se envolva com as questões do patrimônio arqueológico. Quanto mais pessoas se envolverem com o patrimônio arqueológico, entendendo os contextos nos quais ele está inserido e tendo acesso a informações sobre as pesquisas e descobertas, mais fácil será assegurar a proteção de sítios, diminuir o ritmo das destruições por desinformação e coibir os crimes contra esse patrimônio.

É certo, todavia, que ao pressupor a necessidade de transformar o patrimônio arqueológico em um produto, reconhece-se a importância inata de planejar tal ação. Segundo Carvalho Jr. (2002 apud ALMEIDA, 2006), "o planeamento é a aproximação para dirigir a energia humana, objectivando uma finalidade racionalmente predeterminada, ou seja, representa uma acção coordenada de esforços para atingir um determinado objetivo". Visto dessa forma, esbarrase em dois grandes desafios: (10.) a composição de equipes interdisciplinares para o planejamento arqueoturístico, e (2.) a elaboração de planejamentos cada vez mais participativos. 
De modo geral, esse primeiro problema pode ser percebido no planejamento turístico brasileiro como um todo, já que este sempre requer equipes multidisciplinares. São necessários profissionais de turismo trabalhando em conjunto com os de outras áreas envolvidas a depender do segmento pretendido (p. ex. biólogos/Ecoturismo, geólogos/Geoturimo, antropólogos/Turismo Étnico, arqueólogos/Turismo Arqueológico). Todavia, não é incomum que predomine a noção de que os interesses dos turismólogos são sempre opostos aos dos outros profissionais, estes preocupados com a preservação e aqueles, com o dinheiro. Esta noção, além de ser uma inverdade, já que o profissional do turismo precisa buscar a sustentabilidade dos produtos planejados, termina conturbando a realização de trabalhos conjuntos.

Em se tratando de patrimônio cultural, esse problema possui um agravante. No mundo atual, embora se perceba uma forte tendência à homogeneidade, com as mesmas empresas e produtos sendo facilmente acessíveis em locais antes inimagináveis, as diferenças entre os povos que continuam a instigar a curiosidade e os locais que mantêm suas características originais se tornam naturalmente atraentes. Nesse sentido, não só os bens materiais ou monumentos são importantes. As comunidades onde eles se encontram e a história a eles associadas também merecem atenção. Juntos eles compõem um atrativo muito mais forte no mercado turístico. Por isso, conforme Niknami (s/d: 08) "one of the significant challenges facing cultural heritage tourism is to ensure the successful involvement of a wide range of actors concerned with tourism development and planning ${ }^{\prime 37}$.

No Brasil, o MTUR salienta que, para a viabilidade do segmento de Turismo Cultural, profissionais como historiadores, antropólogos, sociólogos, arqueólogos, museólogos, educadores, juntamente com os profissionais de turismo, podem realizar ações complementares em parceria, tais como (BRASIL, 2008: 31):

- Inventariação da oferta turística;

- Diagnóstico da situação da oferta;

- Qualificação, conservação e manutenção de bens culturais;

- Capacitação de recursos humanos para atuar na prestação de serviços turísticos;

- Elaboração e implementação de projetos de interpretação e educação patrimonial;

- Produção e seleção de textos e imagens para fins de promoção do destino turístico.

\footnotetext{
${ }^{37} \mathrm{Um}$ dos principais desafios enfretados pelo turismo patrimonial cultural é o de assegurar o envolvimento de um grande número de atores preocupados com o desenvolvimento e o planejamento do turismo [Tradução: Luciana M. Guimarães].
} 
Os profissionais do turismo precisam garantir a preservação do patrimônio arqueológico para assegurar a atração de turistas e fomentar tanto a geração de renda quanto de melhorias sociais no local onde este se encontra. Os arqueólogos, por sua vez, deveriam lutar por essa preservação por meio de uma participação ativa, mas não exclusiva, no planejamento da atividade arqueoturística.

Tendo esses pressupostos em vista, questiona-se quão preparados estão os profissionais das duas áreas diretamente interessadas no segmento turístico aqui analisado: os profissionais do turismo estão informados e preparados para lidar com o planejamento do Turismo Arqueológico? Na formação dos bacharéis em turismo, em algum momento do curso, aborda-se especificamente a temática da arqueologia brasileira? Mais uma vez, volta-se à questão do quão conhecido e valorizado é o patrimônio arqueológico brasileiro e reflete-se que deveria haver um esforço para inserir a temática da pré-história/ arqueologia nos currículos de graduações que possuem alguma relação com o tema, como é, definitivamente, o caso dos cursos de turismo. Por sua vez, o arqueólogo está preparado para atuar no planejamento do Turismo Arqueológico? Na formação dos arqueólogos, em algum momento, aborda-se a questão do turismo e suas particularidades?

É necessário, segundo Santana (1998), pensar que a formação do arqueólogo direcionada para achar e analisar um bem a partir de um determinado ponto de vista, não os isenta de conhecer a legislação vigente, de saber gerir esse bem/patrimônio, ou, se necessário, vendêlo. Ele complementa (SANTANA, 1998: 41):

Si somos capaces de ofrecer imágenes patrimoniales elaboradas, de calidad y económicamente viables, podríamos evitar algunas - aunque no sean demasiadas - aberraciones presentadas como patrimonio-turístico. Estaríamos así contribuyendo a una formación, no sólo profesional, sino socio-ocupacional.

Ainda há muito espaço para esse debate no território nacional, principalmente na arqueologia, que apenas recentemente vem se consolidando como formação técnicocientífica de profissionais em graduações e cursos técnicos. No entanto, é importante destacar que há mais de duas décadas existem recomendações internacionais para que a proteção do patrimônio arqueológico não seja baseada apenas na aplicação de técnicas arqueológicas, já que depende de variados conhecimentos profissionais e habilidades distintas. O ICOMOS, na década de 1990, já apontava que a gestão do património 
arqueológico requer altos padrões acadêmicos em diferentes disciplinas e que programas de pós-graduação deveriam ser desenvolvidos com ênfase nessa necessidade (proteção e gestão do património arqueológico). Além disso, ressaltava a urgência de se criar mecanismos internacionais para trocas de informação entre os profissionais que lidam com essa gestão/manejo (ICOMOS, 1990).

II.1.1. Espaços para diálogos Interdisciplinares e Participativos: o TURISMo na Gestão do PATRIMÔNIO ARQUEOLÓGICO.

O planejamento turístico está fortemente relacionado à Gestão do Patrimônio Arqueológico (GPA) que é (PARDI, 2002: 20):

vista, por nós, como um conjunto de estudos, análises, reflexões e ações que buscam equacionar informações sobre os bens culturais, os parceiros envolvidos (comunidade, cientistas, autoridades, mídia...), as estruturas (física e administrativa) e as questões econômicas inerentes, visando a otimizar o uso e o retorno à atual geração, a valorização e difusão, bem como a preservação dos sítios ou blocos testemunhos, do acervo gerado, da documentação e do conhecimento produzido para as gerações futuras.

Sob esse entendimento, Pardi (2002) elaborou um esquema (Ilustração II.4) bastante esclarecedor e que ajuda a entender as múltiplas questões ligadas à gestão do patrimônio arqueológico, reproduzido a seguir.

Fernandes (2007:15) também defende que a prática da GPA na atualidade deve considerar "a arqueologia de salvamento (ou de contrato), o turismo cultural, programas e projetos de inventário cultural, valorização cultural, projetos de restauração de edificações históricas, entre outros". 


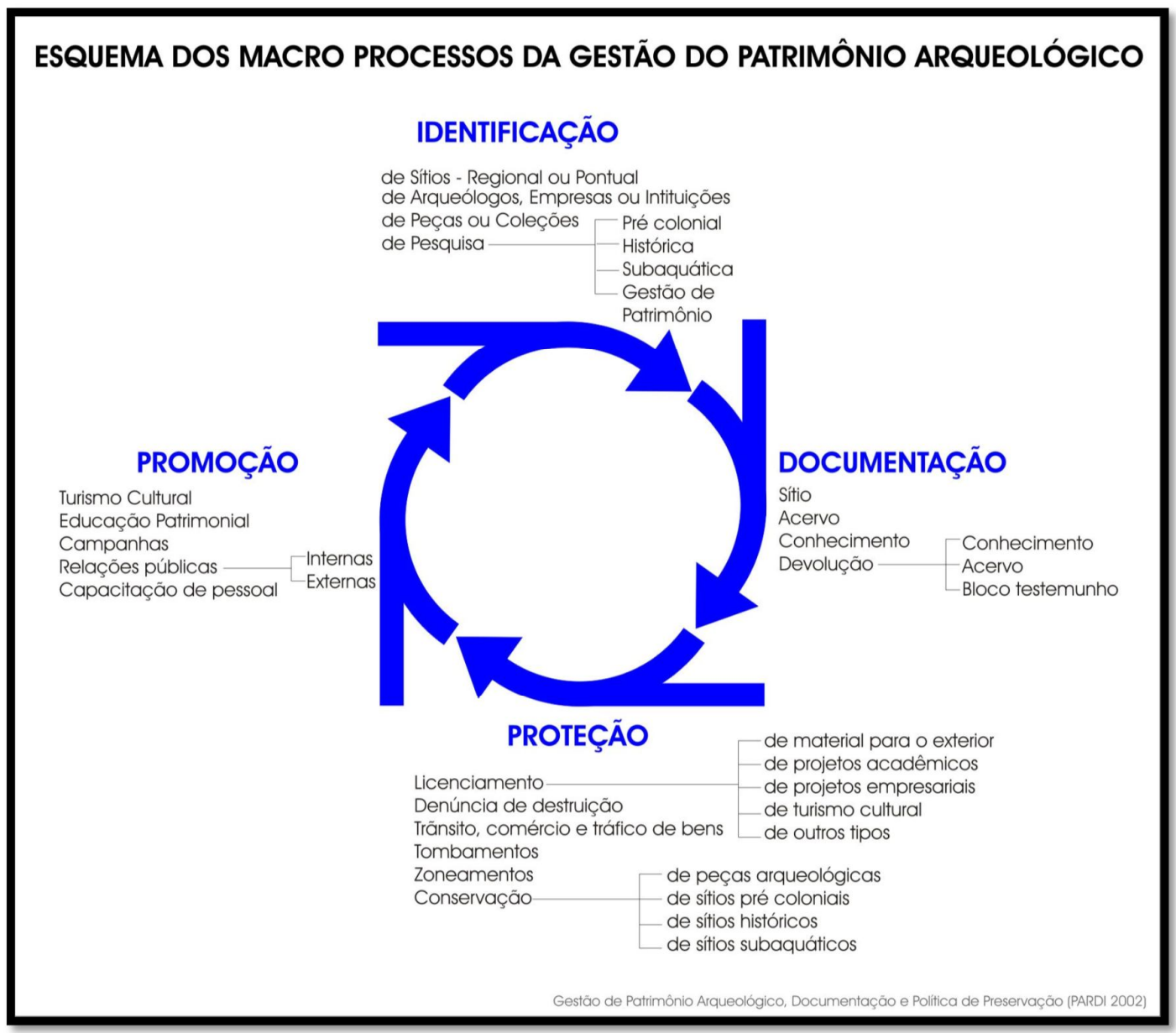

Ilustração II.4: Esquema dos Macro Processos da Gestão do Patrimônio Arqueológico (FonTE: PARDI, 2002: 21).

Ainda assim, sabe-se, informalmente, de casos no Brasil onde recursos arqueológicos não foram incluídos no planejamento turístico, pois os envolvidos, ou não sabiam lidar com eles, ou, seguindo o senso comum da falta de monumentalidade, não acreditavam no seu potencial atrativo. Ainda hoje, Planos de Manejo de áreas naturais protegidas podem não considerar os vestígios arqueológicos como algo que possa fazer parte de áreas abertas à visitação pública. Pelo contrário, esses vestígios ainda são percebidos como mais uma dificuldade. Tal situação precisa ser enfrentada pelo país: conseguir trazer a arqueologia para a pauta dos atores que, em diferentes estâncias, decidem sobre como as descobertas arqueológicas serão apropriadas localmente, regionalmente ou nacionalmente. Isso proporcionaria um grande impacto em termos de publicidade - no sentido de tornar público - e consequentemente de uso turístico sustentável e preservação das mesmas. 
A GPA requer, portanto, além de profissionais de áreas distintas, a cooperação de autoridades governamentais, de empresas privadas ou públicas, da comunidade local e do público em geral.

Entende-se, portanto, que a gestão do patrimônio arqueológico não deva ser a expressão do desejo de um grupo específico - arqueólogos, governantes ou turismólogos - mas, sim, o resultado de um interesse legítimo da sociedade. Nesse sentido, uma observação pertinente é que todo e qualquer planejamento deve ser construído a partir do diálogo entre os interessados, ou seja, dentro dos ideais de planejamento participativo. É importante que os planejadores, os operadores turísticos, os gestores de locais com patrimônio e a comunidade de entorno trabalhem em busca de benefícios mútuos, apesar de possuírem, inicialmente, interesses e necessidades distintas.

Successful tourism at heritage places depends on understanding the different perspectives of tourism operators, heritage managers and communities and then establishing common ground, building relationships and forming partnerships ${ }^{38}$ (A.H.C., s/d: 06)

Concorda-se com Almeida (2006) sobre a necessidade de se perceber a comunidade não apenas como um agente fiscalizador para que as metas estabelecidas sejam alcançadas, mas, principalmente, como um agente na definição das necessidades locais, das prioridades e dos meios para atingir esses objetivos comuns, colocando em prática os princípios da gestão participativa.

Obviamente, todas as medidas e acções estarão subordinadas ao planeamento dos níveis mais elevados. Mas é através da delimitação de espaços geográficos menores e mais homogéneos que, efectivamente, se pode lidar com as questões mais particulares (ALMEIDA, 2006: 45).

Em trabalho exaustivo para a composição de linhas guia para o manejo/gestão de um sítio arqueológico sul coreano, Lim (2005) analisou e resumiu diversos documentos internacionais, levando em consideração que as Cartas Internacionais "(...) do not directly describe a planning process for management of heritage sites, however, most of these

\footnotetext{
${ }^{38}$ O sucesso do turismo em locais com patrimônios culturais depende da compreensão das diferenças de perspectiva existentes entre operadores de turismo, gestores de patrimônio e comunidades e, depois, do estabelecimento de uma base comum, com a formação de relacionamentos e parcerias [Tradução: Luciana M. Guimarães].
} 
charters have principles and recommendations for particular themes and site issues ${ }^{\prime 39}$ (LIM, 2005: 20). Este autor identifica, nos materiais consultados por ele e que relacionavam-se a sítios arqueológicos, que existem basicamente três fases importantes na gestão de um sítio: documentação, análise e reação (cf. última linha da Tabela II.1).

TABELA II.1:

Phases of management planning process.

\begin{tabular}{|l|l|l|l|}
\hline \multicolumn{1}{|c|}{ PLAN } & \multicolumn{1}{|c|}{ PROCESS I } & \multicolumn{1}{c|}{ PROCESS II } & \multicolumn{1}{c|}{ PROCESS III } \\
\hline Burra Charter (1991) & $\begin{array}{l}\text { Understand } \\
\text { Significance }\end{array}$ & Develop Policy & Manage \\
\hline Michael \& Sharon (1995) & $\begin{array}{l}\text { Location, } \\
\text { Identification, } \\
\text { Documentation }\end{array}$ & Assessment & $\begin{array}{l}\text { Planning } \\
\text { Decision making } \\
\text { Implementation }\end{array}$ \\
\hline Martha Demas (2000) & $\begin{array}{l}\text { Identification } \\
\text { description }\end{array}$ & $\begin{array}{l}\text { Assessment } \\
\text { Analysis }\end{array}$ & Response \\
\hline $\begin{array}{l}\text { Bernard M. Feilden } \\
\text { Jukka Jokilehto (2000) }\end{array}$ & Description & $\begin{array}{l}\text { Evaluation and } \\
\text { Objectives }\end{array}$ & $\begin{array}{l}\text { Prescription for } \\
\text { overall site } \\
\text { management }\end{array}$ \\
\hline New Guidelines (2005) & Documentation & Analysis & Response \\
\hline
\end{tabular}

FONTE: LIM, 2005: $20^{40}$

O cumprimento dessas três etapas é tido como fundamental na elaboração de um Plano de Manejo para sítios arqueológicos, que, como ele ressalta, não pode, nem deve, ser entendido apenas como uma política de manutenção do sítio (LIM, 2005: 23):

The main purpose of management planning for archaeological sites is to preserve monuments in situ and retain their cultural significance through systematic interpretation. The management plan can be divided into various periods (long terms, mid term, and short term) including daily conservation processes to check on conditions. The management plan is related with almost all the processes not only in planning for conservation but also in fiscal and legal

39 (...) não descrevem, diretamente, um processo de planejamento da gestão de sítios arqueológicos. No entanto, muitas destas Cartas dispõem de princípios e recomendações voltados para temas específicos e para problemas relativos aos sítios [Tradução: Luciana M. Guimarães].

${ }^{40}$ Bibliografia citada na tabela (cf. LIM, 2005): *Australia-ICOMOS. Burra Charter (revised) for the conservation of Places of cultural significance.1999. *Pearson, Michael and Sullivan, Sharon . Looking After Heritage Place: The Basics of Heritage Planning for Managers, Landowners and Administrators. Carton, Victoria: Melbourne University Press. 1995. *Demas, Martha. Management Planning of Archaeological Site: Planning for Conservation and Management of Archaeological Sites. Greece. Getty Institute. 2000. *Bernard M.Feilden and Jukka Jokillehto. Management Guidelines for World Cultural Heritage Sites. Rome: ICCROM. 1993. 
policies such as tourism and public policy. Based on those surrounding factors, cultural values and contemporary socio-economic values should be considered at the same time ${ }^{41}$

Carbone e Costa (2006) analisaram as formas de gestão do patrimônio arqueológico em Portugal e em alguns outros países e compararam-nas com as melhores práticas para a atividade, bem como com o que eles classificaram de experiências inovadoras com o objetivo de criar "um modelo novo, mais completo, articulado e adequado às exigências da sustentabilidade".

Um dos aspectos mais peculiares do modelo proposto é o forte dinamismo, a forte aposta na interdisciplinaridade e na forma integrada de gerir o património arqueológico, segundo dois aspectos paralelos:

- Património arqueológico enquanto testemunha material das "raízes" culturais da população local, à qual tem que ser "devolvida" esta herança através da apresentação e divulgação;

- Vocação turística do património arqueológico, cuja exploração tem, por sua parte, um duplo objectivo: a criação de produtos turísticos de qualidade e o crescimento socioeconómico da população no destino.

O turismo é portanto escolhido como veículo principal de exploração das possibilidades de crescimento cultural e socio-económico que o património arqueológico pode proporcionar. Trata-se, porém, de uma nova visão de turismo, sobretudo do ponto de vista do seu planeamento, tendo como objectivo a participação da população, dos heritage managers locais, dos técnicos do património e dos técnicos de turismo (CARBONE E COSTA, 2006: 02).

Carbone e Costa (2006) apontam, também, algumas limitações percebidas em um estudo de caso específico em Portugal, e sugerem, a partir de suas análises, um modelo que consiga articular de forma dinâmica (a) a conservação e musealização, item que aborda, entre outras coisas, o papel dos arqueólogos no processo de planejamento e gestão, inclusive turística da área, bem como sua interação com o público, (b) a relação com a população local, onde os autores ressaltam a necessidade de desenvolvimento de projetos de educação formal e não formal, e (c) a relação com o turismo, onde abordam a criação de produtos turísticos de qualidade, a satisfação do turista etc. Porém, alertam que (CARBONE E COSTA, 2006: 10):

[o] que parece certo, ao fim de várias reflexões, é que não é possível criar modelos rígidos na gestão de sítios arqueológicos com vista à exploração turística e o aproveitamento para o desenvolvimento local, sobretudo devido à dificuldade de implementação na infinita variedade

\footnotetext{
${ }^{41}$ O objetivo principal de um plano de manejo de sítios arqueológicos é preservar os monumentos in situ, mantendo-lhes a importância cultural por meio de uma interpretação sistemática. O plano de manejo pode ser dividido em vários períodos (de longo, médio e curto prazos), incluindo processos de conservação diários para verificar as condições vigentes. O plano de manejo relaciona-se a quase todos os processos, não apenas no que toca ao planejamento da conservação, mas também no que diz respeito a políticas fiscais e legais, como, por exemplo, políticas turísticas e públicas. Considerando-se a existência de todos estes fatores interrelacionados, os valores culturais e os valores socioeconômicos contemporâneos devem ser levados em consideração simultaneamente [Tradução: Luciana M. Guimarães].
} 
de realidades arqueológicas existentes. Isto não quer dizer que não possam existir algumas directrizes gerais na abordagem à conservação dos sítios arqueológicos, sua fruição turística e sua relação com o desenvolvimento local.

Diante desses dados, percebe-se um cruzamento de fatos preocupantes no Brasil. No turismo, assiste-se à decadência de destinos turísticos relativamente recentes pela total falta de planejamento em relação à atividade. Na arqueologia, vê-se que a disseminação dessa ideia de GPA mais abrangente ainda não parece ter sido incorporada nas práticas profissionais. A lentidão em aceitar o turismo como fator importante para a promoção e a proteção do patrimônio arqueológico, perfeitamente cabível no processo de GPA, não traz benefícios. Ao contrário, deixa diversos sítios arqueológicos vulneráveis e é um grave desperdício de oportunidades.

\section{II.2. 'Melhores Práticas' em Turismo Arqueológico - Síntese de literatura Específica} E CORRELATA.

Embora esteja claro que o turismo é parte importante no processo de gestão do patrimônio arqueológico, no Brasil, infelizmente, o uso turístico do patrimônio arqueológico ainda é visto com ressalvas, principalmente pelos arqueólogos. Há, de fato, sinais de mudança. Todavia, uma análise rápida sobre a evolução da conjugação dessas áreas no país mostra que esta mudança vem ocorrendo lentamente.

Em 2005, o XIII Congresso da Sociedade de Arqueologia Brasileira (SAB) propôs o tema Arqueologia, Patrimônio e Turismo, demonstrando estar atenta e interessada nessa integração. $\mathrm{Na}$ época, constatou-se que ainda havia muito a se pesquisar cientificamente sobre a relação entre o turismo e arqueologia. No mesmo ano, Manzato (2005), em pesquisa bibliográfica para elaboração de dissertação de mestrado, encontrou, na produção acadêmica de circulação nacional, apenas três trabalhos: um artigo (ETCHEVARNE, 1992), uma monografia (RIES, 2003) e um capítulo de livro (MORAIS, 2003). 
Widmer (2009: 69), em um livro sobre segmentação turística, aponta o Turismo Arqueológico como "um campo de estudos ainda recente e carente de pesquisas no país", relacionando os trabalhos de Morais (2003), Ries (2003), Scatamacchia (2005), Manzato (2005), Santos (2007) e Veloso e Cavalcanti (2007) como as referências nacionais por ela encontradas que possuíam "rigor científico".

Durante a elaboração desta tese (2007-2012), outras referências bibliográficas brasileiras puderam ser acessadas e se somam a essa listagem, mas o número ainda não é muito expressivo, ainda mais quando se buscam publicações nacionais que reúnam princípios e diretrizes voltados especificamente ao uso turístico sustentável do patrimônio arqueológico. Percebeu-se que, em todo o mundo, há carência de referências voltadas exclusivamente ao Turismo Arqueológico, de modo que a busca pelas referências precisou se expandir, realizando-se a partir do que aqui foram considerados como aspectos específicos (i.e. planejamento turístico de sítios arqueológicos e turismo arqueológico sustentável) ou mais genéricos (i.e. gestão de sítios arqueológicos, planos de manejo para sítios arqueológicos etc.). Porém, mesmo no segundo caso, foi difícil encontrar documentos relevantes para a pesquisa. Diante dessa realidade, pinçaram-se instruções a partir de fontes ainda mais genéricas, como as relacionadas ao patrimônio cultural em geral.

Através da consulta a materiais estrangeiros e, também, à literatura nacional sobre temáticas relacionadas, foi possível sistematizar uma série de informações úteis a planejadores turísticos, bem como a gestores de locais com patrimônio arqueológico, considerando que quanto mais bem informados estiverem esses atores, melhor será o produto oferecido e mais satisfeito estará o turista. Essa satisfação, como discutido anteriormente, é de suma importância para garantir que a visitação arqueoturística resulte na compreensão, por parte da sociedade global, da importância do patrimônio arqueológico e, consequentemente, garanta a sua preservação.

Mota, Ladeiras e Costa (s/d) propõem quatro fases operacionais que deveriam ser seguidas por qualquer destino turístico na realização de um planejamento estratégico, sendo elas: 
Fase 1 - Auditoria - fase em que se reconhece o estágio atual do Turismo no destino (caracterizando de forma precisa todas as variáveis e agentes que interferem, directa ou indirectamente, no desenvolvimento da actividade);

Fase 2 - Planeamento - fase em que se fixa um modelo de actuação sobre a atividade turística do destino de forma a atingir as metas para ele traçadas;

Fase 3 - Desenvolvimento - fase em que se procede ao estabelecimento de programas/acções/directrizes das quais resultará a implementação do modelo de actuação desenhado na fase imediatamente anterior;

Fase 4 - Monitorização - fase em que se avaliam - de forma continuada - os resultados obtidos de modo a impulsionar, coordenar e integrar, a indústria, no conjunto macroeconómico em que está inserida.

Shunnaq, Schwab e Reid (2008) descrevem os esforços realizados durante dez anos para a proposição de um circuito turístico no norte da Jordânia, tendo como fundamento o patrimônio arqueológico local. Os autores indicam os benefícios que podem advir do desenvolvimento de um novo turismo, em contraposição ao turismo convencional, apontando fortemente a necessidade da participação comunitária nas decisões. Eles propõem um Plano de Turismo baseado nas três seguintes fases: (I) preparação para o turismo, avaliação, (II) criação do circuito turístico, (III) implementação do plano.

Alfonso (2009) relata, no artigo O Patrimônio Arqueológico e sua Vinculação a Circuitos Turísticos não Convencionais no Brasil, os pressupostos que a guiaram na organização de um circuito turístico no nordeste brasileiro envolvendo o patrimônio arqueológico: (i) o conceito de paisagem cultural e (ii) a preservação e sustentabilidade, que a autora define como " $a$ utilização dos bens arqueológicos pela atividade turística" pensada segundo as perspectivas da "sustentabilidade", do "contexto local" e do "desenvolvimento participativo". Em seu estudo, foram seguidas as seguintes etapas para a formatação do Circuito Turístico do Sertão Alagoano, aqui resumidas:

1. Inventário da oferta turística e avaliação dos recursos arqueológicos dos municípios envolvidos, para o qual foram realizadas (a) oficinas de construção da imagem turística, (b) oficinas de identidade e patrimônio e de sensibilização quanto ao turismo, além do (c) curso Identidade e Turismo, para capacitação docente;

2. Diagnósticos da atividade turística, em quatro temáticas diferentes: meios de hospedagem, estabelecimentos de alimentação, recursos naturais e recursos culturais e arqueológicos; 
3. Programa de uso turístico do patrimônio arqueológico da região, realizado em três diferentes frentes: sensibilização quanto ao turismo, capacitação para a atividade, e sensibilização quanto ao patrimônio.

Observa-se que o trabalho em questão foi desenvolvido a partir de iniciativa governamental, através do IPHAN, em sua superintendência regional. Isso dá sentido aos apelos encontrados na maioria dos artigos e textos aqui consultados em relação à necessidade fundamental de apoio governamental no desenvolvimento das ações ligadas ao Turismo Arqueológico e, principalmente, na importância de que isso se desdobre em iniciativas que envolvam a comunidade local. Neste caso, a preocupação passa a ser a continuidade do processo. Tal realidade contrasta, por exemplo, com outra situação brasileira, na região da Serra da Capivara, já citada nesta tese, onde a falta de apoio do poder público faz com que toda a infraestrutura criada, que permitiria a atração de cerca de três milhões de turistas por ano, permaneça ociosa, fundamentalmente devido à falta de um acesso apropriado: a construção de um pequeno aeroporto, capaz de receber voos regionais, que auxiliaria na transformação dessa realidade. Ao invés disso, os poucos turistas que se habilitam a visitar o local, aventuram-se por uma das cinco piores estradas brasileiras (Ý́ZIGI, 2009).

Enfim, existem diversos obstáculos para alcançar a sustentabilidade no turismo patrimonial/cultural/arqueológico, dentre os quais Niknami (s/d: 08) relaciona, entre os maiores, "the lack of financial resources, poor forms of governance, inappropriate Project management process, ineffective enforcement of regulations, corruption and lack of support for heritage conservation ${ }^{\prime \prime 2}$. Como se percebe, embora estas questões estejam sendo levantadas num artigo sobre o Turismo Cultural no Irã, elas podem ser perfeitamente interpostas à realidade brasileira, levando à conclusão que a atuação do poder público neste processo é de suma importância, e a sua ausência, por outro lado, torna o conceito de sustentabilidade muito difícil de ser alcançado. Prefere-se, contudo, concordar que:

Nas estatísticas do turismo, não é possível a distinção entre o 'sustentável' e o 'insustentável'. O discurso político tende a privilegiar o 'sustentável', da mesma forma em que o pulveriza, em sentidos e significados diversos, capazes de banalizá-lo, transformando-o em utopia contemporânea. Mas existe uma direção possível que transcende os imediatismos políticos e busca consolidar a participação cidadã, em escalas local e global. É nesse movimento cidadão

42 (...) a indisponibilidade de recursos financeiros, as más formas de gestão, os processos de gestão inapropriados, a execução ineficaz dos regulamentos, a corrupção e a falta de apoio à conservação do patrimônio [Tradução: Luciana M. Guimarães]. 
que o turismo poderá se consolidar como veículo de transformação social, que transcende fronteiras políticas e atinge o campo da ética global (IRVING et al., 2005: 07).

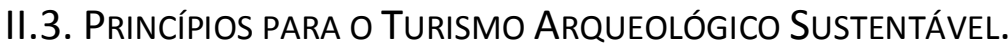

Em vez de adotar um conceito para turismo sustentável, pode-se pensá-lo através de itens relacionados ao conceito de desenvolvimento sustentável, sob o qual aquele estabelece suas bases teóricas. Seriam eles (GUIMARÃES, 2003: 18):

i. Direito das futuras gerações de desfrutarem de destinos turísticos conservados,

ii. Satisfação das comunidades receptoras,

iii. Satisfação dos turistas,

iv. Proteção dos recursos ambientais,

v. Respeito aos bens culturais.

Cabe observar, no entanto, que a sustentabilidade no turismo não é uma prerrogativa do arqueoturismo ou de qualquer outro segmento específico (como o Ecoturismo, por exemplo). Na verdade, é um desafio que nasceu junto com os próprios desafios do 'desenvolvimento sustentável', definido pelo Relatório Bruntdland, em 1987, como "aquele que atende às necessidades do presente sem comprometer a possibilidade de as gerações futuras atenderem às suas próprias necessidades" (Comıssão, 1991).

Para o Turismo Arqueológico, a busca pela sustentabilidade deve ser no sentido mais amplo do termo, em todos os seus eixos: ambiental, social, econômico e cultural e, portanto, deve considerar esses preceitos. Para isso, no entanto, é necessário seguir alguns princípios ou diretrizes específicas.

No material americano Guide to Best Practices for Archaeological Tourism, melhores práticas são anunciadas como alicerces para a criação de quaisquer orientações para visitar sítios arqueológicos e lugares históricos e para orientar o planejamento de visitas e o comportamento dos operadores turísticos e visitantes. São elas (AIA, s/d):

1. Archaeological sites and historical places are finite, fragile, and non-renewable resources: Archaeological sites and historical places are unique and irreplaceable. Destruction of a site is permanent and irreversible. It is important to remember that sites are fragile and vulnerable to exposure to elements, looting, and irresponsible/unrestricted tourism. Destruction of sites 
results not only in the loss of the physical remains but also the information that may have been gleaned from examination and study of the area. The loss of information is just as critical as the loss of sites as it affects our understanding of the cultures that built them.

2. Archaeological sites exist within a larger setting that includes both the environment and the local communities: Good practices must take into account the impact of archaeological tourism on the site and the natural environment in which the site is located. Guidelines for sustainable tourism should respect the values, ideals, and rights of the local communities that exist alongside the sites. Guidelines for good practices must be created in cooperation with the local population.

3. Removal or destruction of cultural material is unethical and illegal: Archaeological sites are generally protected by laws that prohibit the removal of any cultural (and in some cases, natural) materials. Removing or trafficking in cultural materials is illegal. Looting destroys a site and compromises the integrity of any information that may be retrieved from it ${ }^{43}$.

Os princípios norteadores de um Turismo Arqueológico responsável (Tabela II.2) foram comparados com recomendações, retiradas de outros materiais genéricos consultados, conforme explicado anteriormente. Em geral, esses materiais relacionam-se ao Turismo Cultural (Cultural Tourism ou Heritage Tourism) e foram desenvolvidos ou por agências governamentais de diversos países, ou por organizações ligadas à cultura. Os estrangeiros, embora com suas particularidades relativas à singularidade dos recursos locais possuem, de maneira geral, princípios e diretrizes que podem ser percebidos como universais e, por isso, aproveitáveis à realidade brasileira.

Observe-se que, nos materiais em língua inglesa, é possível encontrar tanto o termo Cultural Tourism quanto Heritage Tourism sendo utilizados. Porém, é um erro pensar que os dois são sempre sinônimos. Na Austrália, por exemplo, o Turismo Cultural, o Ecoturismo e o Turismo Indígena são considerados Heritage Tourism, entendendo-se que a significância patrimonial está relacionada à importância natural e cultural do lugar (A.H.C., 2001). Esta tese

\footnotetext{
${ }^{43}$ 1. Sítios arqueológicos e locais históricos são finitos, frágeis, além de serem recursos não-renováveis: sítios arqueológicos e locais históricos são únicos e insubstituíveis. A destruição de um sítio arqueológico é permanente e irreversível. É importante lembrar que sítios arqueológicos são frágeis e vulneráveis à exposição às intempéries, a pilhagens e a formas irresponsáveis e irrestritas de turismo. A destruição de sítios arqueológicos resulta não somente na perda dos vestígios físicos, mas também na perda de informações que poderiam ser obtidas a partir da análise e do estudo da área. Esta perda de informação é tão crucial quanto a perda dos sítios arqueológicos em si, já que afeta o nosso entendimento das culturas que os construíram. 2. Sítios arqueológicos existem dentro de um contexto amplo que inclui tanto o ambiente, quanto as comunidades locais: boas práticas de turismo devem levar em consideração o impacto do turismo arqueológico no sítio e no ambiente natural em que ele está localizado. As diretrizes para o turismo sustentável devem respeitar os valores, as ideias e os direitos das comunidades locais existentes nos arredores dos sítios arqueológicos e devem ser criadas em cooperação com a população local. 3. A remoção ou destruição de material cultural é uma prática antiética e ilegal: os sítios arqueológicos são, normalmente, protegidos por leis que proíbem a remoção de quaisquer materiais culturais (e, em alguns casos, naturais). Remover ou traficar materiais culturais é ilegal. As pilhagens destroem os sítios arqueológicos e comprometem a integridade de qualquer informação que poderá ser obtida a partir deles [Tradução: Luciana M. Guimarães].
} 
compartilha desse entendimento, embora não seja usual o termo Turismo Patrimonial no Brasil.

TABELA II.2:

The guiding principles for responsible archaeological tourism

\begin{tabular}{|c|}
\hline 1. Preserve and maintain the site. \\
\hline 2. Support site preservation efforts. \\
\hline 3. Balance economic considerations against cultural heritage concerns. \\
\hline 4. Encourage and support community involvement in the projects. \\
\hline $\begin{array}{r}\text { 5. Encourage the participation of local civic groups and businesses in planning the future of } \\
\text { the site and make sure that they benefit from the efforts. }\end{array}$ \\
6. Provide proper interpretation. \\
\hline 7. Encourage education and understanding of sites. \\
\hline
\end{tabular}

FONTE: AIA, $s / d^{44}$.

Faz-se imprescindível apresentar, neste momento, para fins comparativos, os princípios estabelecidos pela Internacional Cultural Tourism Charter. Managing Tourism at Places of Heritage Significance (ICOMOS, 1999b), também conhecida como Carta Ethos. Esta Carta visava, entre outras coisas, encorajar a formulação de diretrizes detalhadas pelas partes interessadas, facilitando a prática dos princípios ali propostos, de acordo com as realidades específicas, ou requisitos particulares, de organizações e comunidades. São eles:

Principle 1. Since domestic and international tourism is among the foremost vehicles for cultural exchange, conservation should provide responsible and well managed opportunities for members of the host community and visitors to experience and understand that community's heritage and culture at first hand.

Principle 2. The relationship between Heritage Places and Tourism is dynamic and may involve conflicting values. It should be managed in a sustainable way for present and future generations.

\footnotetext{
${ }^{44}$ Princípios norteadores de um Turismo Arqueológico responsável. 1. Preserve e mantenha o sítio. 2. Apoie os esforços de preservação do sítio. 3. Compare considerações econômicas com os interesses do patrimônio cultural. 4. Incentive e apoie a participação da comunidade nos projetos. 5. Incentive a participação de autoridades locais, grupos cívicos e empresas no planejamento do futuro do local e certifique-se de que todos se beneficiam com os esforços. 6. Forneça uma interpretação adequada. 7. Incentive a informação e compreensão das áreas [Tradução: Luciana M. Guimarães].
} 
Principle 3. Conservation and Tourism Planning for Heritage Places should ensure that the Visitor Experience will be worthwhile, satisfying and enjoyable.

Principle 4. Host communities and indigenous peoples should be involved in planning for conservation and tourism.

Principle 5. Tourism and conservation activities should benefit the host community.

Principle 6. Tourism promotion programmes should protect and enhance Natural and Cultural Heritage characteristics ${ }^{45}$.

No material brasileiro (BRASIL, 2008), o governo reconhece que "a maioria dos produtos turísticos carece de qualificação e há, ainda, muito a ser trabalhado para se chegar à competitividade e à sustentabilidade" e afirma que, para o desenvolvimento desse segmento específico, devem ser observados os seguintes aspectos específicos:

1. A viabilidade para o Turismo Cultural.

- Identificar e avaliar se na região existem atrativos culturais significativos, efetivos ou potenciais, que possam motivar o deslocamento do turista especialmente para conhecê-los.

2. Aspectos legais.

3. Identificação de agentes e parceiros.

4. Envolvimento das comunidades.

5. Tematização: conferindo identidade aos produtos turísticos

6. Aspectos gerais de estruturação do segmento.

- Estrutura física

- Serviços e Atividades

7. Agregando valor aos atrativos.

No material australiano (A.H.C., 2001), a preocupação central é justamente favorecer o trabalho conjunto de diversos atores, como operadores turísticos, gestores e comunidade. Por isso, uma seção é destinada a esclarecer as diferentes perspectivas desses grupos, de modo que possa haver uma compreensão mútua entre eles. O material salienta que, embora cada um possua seu próprio ponto de vista, há uma ampla gama de pontos comuns entre eles, como providenciar acesso ao público, apresentar e proteger o significado dos lugares e

\footnotetext{
45 Princípio 1: Já que o turismo doméstico e internacional encontra-se entre os principais veículos de intercâmbio cultural, a conservação deverá fornecer aos membros da comunidade anfitriã e aos visitantes oportunidades de gestão efetiva e responsável para que eles experimentem e obtenham um conhecimento pessoal acerca do patrimônio e da cultura da comunidade. Princípio 2: A relação entre os locais com patrimônios culturais e o turismo é dinâmica, podendo envolver conflitos de valores. Esta relação deve ser desenvolvida de modo sustentável no interesse de gerações presentes e futuras. Princípio 3: A conservação e o planejamento turístico para locais com patrimônios culturais devem garantir que a experiência do visitante seja válida, satisfatória e agradável. Princípio 4: As comunidades anfitriãs e grupos indígenas devem ser envolvidos no processo de planejamento da conservação e do turismo. Princípio 5: Tanto o turismo quanto as atividades de conservação devem beneficiar a comunidade anfitriã. Princípio 6: Os programas para a promoção do turismo devem proteger e reforçar as características dos patrimônios naturais e culturais [Tradução: Luciana M. Guimarães].
} 
a necessidade de alcançar a sustentabilidade. Também são descritos princípios a serem seguidos (abaixo) e linhas mestras de atuação (Tabela II.3).

1. Recognise the importance of heritage places

2. Look after heritage places

3. Develop mutually beneficial patnerships

4. Incorporate heritage issues into business planning

5. Invest in people and places

6. Market and promote products responsibly

7. Provide high quality visitor experiences

8. Respect Indigenous rights and obligations ${ }^{46}$.

TABELA II.3:

Linhas mestras para Turismo Arqueológico sustentável

\begin{tabular}{|c|}
\hline 1. Understanding heritage significance. \\
\hline 2. Forming partnerships. \\
\hline 3. Creating a quality visitor experience. \\
\hline 4. Developing indigenous tourism. \\
\hline 5. Planning for a sustainable business. \\
\hline
\end{tabular}

FONTE: A.H.C, $2001^{47}$.

O Best Practice Guide (LMG 2003-2006) descreve um programa desenvolvido em pequenos municípios de regiões da Alemanha, Holanda e Inglaterra. Este programa ajudou os participantes a posicionarem o Turismo Cultural e Patrimonial como uma atividade sustentável e de importância para o desenvolvimento das suas economias. O resultado foi obtido através de ajuda na definição e valorização dos recursos, da sua expansão a nível local, regional e internacional, do envolvimento efetivo com as comunidades locais e com as empresas, da facilitação da pesquisa, visitas de estudo, desenvolvimento de habilidades, compartilhamento de ideias e boas práticas e do estímulo ao desenvolvimento de produtos

\footnotetext{
${ }^{46}$ 1. Reconhecer a importância dos locais patrimoniais. 2. Cuidar dos patrimônios. 3. Estabelecer parcerias de benefício recíproco. 4. Incorporar questões patrimoniais ao planejamento comercial. 5. Investir em pessoas e locais. 6. Comercializar e promover os produtos de maneira responsável. 7. Proporcionar aos visitantes experiências turísticas de alta qualidade. 8. Respeitar o direito e as obrigações dos povos indígenas [Tradução: Luciana M. Guimarães].

47 1. Compreender o significado do patrimônio. 2. Estabelecer parcerias. 3. Proporcionar aos visitantes uma experiência turística de qualidade. 4. Promover o turismo local. 5. Planejar um negócio baseado em sustentabilidade.
} 
turísticos culturais locais. Os seis passos indicados para atingir as metas estabelecidas podem ser vistos na Tabela II.4.

TABELA II.4:

The Six Steps Process

\begin{tabular}{|c|} 
1. Research \\
- An audit, or clear picture, of current cultural heritage assets or 'products'; \\
- Evidence of the visitor profile (the number and type of visitors attracted). \\
2. Dialogue. \\
\hline 3. Product Development. \\
\hline 4. Skills Development and Training. \\
5. Marketing and Promotion. \\
\hline 6. Monitor, Evaluate, Review and Revise.
\end{tabular}

FONTE: LMG, 2003-2006 ${ }^{48}$.

O material Cultural Heritage Tourism - Strategy 2005-2007 (RIKSANTIKVARICÄMBETET 20052007) explica que o Turismo Cultural/Patrimonial passou a ser parte do trabalho do Conselho do Patrimônio Cultural Nacional da Suécia sob a visão que, além de tornar o patrimônio urgente e acessível, ele deve ser utilizável e, para isso, foram estabelecidas as seguintes estratégias:

1. To bring forth good examples

2. To maintain a continuous dialogue with the surrounding world

3. To enhance the awareness of the use of cultural heritage and history

4. To contribute to regional development

5. To incite renewal and development of method

6. To create cooperation and respect ${ }^{49}$.

A sistematização desses trabalhos esclarece que o planejamento do Turismo Patrimonial/Cultural não é algo pensado isoladamente. O ponto de partida é sempre o reconhecimento da importância dos bens (materiais e imateriais) com os quais se pretende trabalhar turisticamente, visando alcançar o ideal de preservação do patrimônio e a geração de benefícios para as comunidades do seu entorno, sempre fomentando diálogos.

\footnotetext{
48 1. Pesquisa - um inventário, ou ao menos uma ideia clara, dos bens patrimoniais ou dos "produtos"; conhecimento do perfil do visitante (o número e o tipo de visitante atraído pelo patrimônio). 2. Diálogo. 3. Desenvolvimento do produto. 4. Desenvolvimento de competências e treinamento. 5. Marketing e promoção do produto. 6. Monitoramento, avaliação, revisão e alteração [Tradução: Luciana M. Guimarães].

49 1. Geração de bons exemplos. 2. Manutenção de um diálogo contínuo com as comunidades de entorno. 3. Promoção da sensibilização do uso do patrimônio cultural e da história. 4. Contribuição para o desenvolvimento regional. 5. Estímulo à renovação e desenvolvimento de metodologias. 6. Criação de cooperação e respeito mútuo [Tradução: Luciana M. Guimarães].
} 
Certamente não é uma tarefa simples, e nem sempre os objetivos são atingidos quando os produtos são disponibilizados no mercado. No entanto, é preciso reconhecer que existem profissionais interessados no desenvolvimento de práticas mais sustentáveis.

Além das considerações em termos de Arqueoturismo, Turismo Cultural e Turismo Patrimonial, decidiu-se pela inclusão de recomendações para o planejamento da atividade ecoturística, considerando alguns aspectos importantes: (i) considerando a discussão anterior de planejar o Turismo Arqueológico na perspectiva de complementação de roteiros pré-existentes, atingindo um público muito mais amplo; (ii) ponderando que o conceito do Ecoturismo sugere que o patrimônio cultural, como parte integrante do ambiente, também deve ser pensado sob a ótica da sustentabilidade, conservado e interpretado para o público e (iii) lembrando que na região de abrangência deste trabalho, a Amazônia, esta é a atividade principal, assim como ocorre em muitas outras regiões brasileiras (maior detalhamento nos capítulos seguintes).

No Brasil, o Ecoturismo é definido pela EMBRATUR (1994: 19) como:

Um segmento da atividade turística que utiliza de forma sustentável o patrimônio natural e cultural, incentiva sua conservação e busca a formação de uma consciência ambientalista através da interpretação do ambiente, promovendo o bem-estar das populações envolvidas.

Embora distorções tenham sido percebidas entre o conceito e a prática da atividade no país (GUIMARÃES, 2003), acredita-se que o modismo venha diminuindo e esses casos estejam sendo resolvidos gradativamente. Dessa maneira, resolveu-se incluir análises importantes sobre a atividade ecoturística que podem ser aproveitadas para a atividade de Turismo Arqueológico, todas provenientes da publicação Manual de Ecoturismo de Base Comunitária: ferramentas para um planejamento responsável, do WWF Brasil (2003):

a) Potencial econômico $x$ Proteção ambiental.

- A atividade só deve ser desenvolvida quando o potencial de impactos ambientais do ecoturismo é avaliado e considerado aceitável;

- Qualquer área natural que receba a visitação ecoturística deve possuir mecanismos para monitoramento e controle dos impactos ambientais;

- Os rendimentos econômicos do ecoturismo devem colaborar para a proteção da área como um todo.

b) Potencial econômico x Participação e benefício da comunidade.

- (...) Geralmente, os impactos da atividade sobre as comunidades são percebidos apenas quando atingem grandes dimensões e os benefícios esperados não ocorrem. Isso acontece porque: 
i. Nem sempre são utilizados os mecanismos participativos e de interpretação da percepção das expectativas e necessidades das comunidades sobre o ecoturismo na fase inicial do desenvolvimento da atividade.

ii. A atividade começa a se desenvolver por força da demanda turística ao invés de por iniciativa da comunidade local.

A partir dessas análises, o WWF Brasil (2003) dividiu o referido manual em três seções, que podem ser visualizadas resumidamente na Tabela II.5.

TABELA II.5:

Visão para um turismo responsável

\begin{tabular}{|l|l|l|}
\hline $\begin{array}{c}\text { Seção 1: Planejamento } \\
\text { Estratégico - Instrumentos } \\
\text { para planos, diagnósticos e } \\
\text { desenvolvimento de projetos. }\end{array}$ & $\begin{array}{c}\text { Seção 2: Implementação } \\
\text { Responsável - Instrumentos } \\
\text { para desenvolvimento físico, } \\
\text { educação e capacitação. }\end{array}$ & $\begin{array}{l}\text { Seção 3: Gestão Integrada - } \\
\text { Instrumentos para controle, } \\
\text { administração e participação. }\end{array}$ \\
\hline $\begin{array}{l}\text { 1. Planejamento do } \\
\text { Ecoturismo }\end{array}$ & $\begin{array}{l}\text { 5. Infraestrutura de Apoio ao } \\
\text { Ecoturismo }\end{array}$ & $\begin{array}{l}\text { 9. Monitoramento e Controle } \\
\text { de Impactos de Visitação }\end{array}$ \\
\hline $\begin{array}{l}\text { 2. Levantamento do potencial } \\
\text { Ecoturístico (Inventário) }\end{array}$ & 6. Manejo de Trilhas & $\begin{array}{l}\text { 10. Administração e Práticas } \\
\text { Contábeis }\end{array}$ \\
\hline 3. Elaboração do Produto & 7. Interpretação Ambiental & $\begin{array}{l}\text { 11. Participação Comunitária } \\
\text { e Parcerias }\end{array}$ \\
\hline 4. Viabilidade Econômica & 8. Programa de Capacitação & $\begin{array}{l}\text { 12. Contribuição de } \\
\text { Voluntários em Projetos de } \\
\text { Ecoturismo }\end{array}$ \\
\hline & & $\begin{array}{l}\text { 13. Pesquisas na Atividade de } \\
\text { Ecoturismo. }\end{array}$ \\
\hline
\end{tabular}

FONTE: Resumido de WWF Brasil, 2003.

De posse desses dados, decidiu-se pela reunião das principais recomendações de todos os materiais consultados, construindo, a partir da bibliografia fundamental (ou seja, voltada às melhores práticas em Turismo Arqueológico) (AIA, s/d) e das complementares (BRASIL, 2008; A.H.C., 2001; CARTER, 2001; CONALCUTA, S/D; ICOMOS, 1999; ICOMOS, 2002; LMO 2003-2006; RIKSANTIKVARICÄMBETET 2005-2007; WWF BRASIL, 2003), uma série de princípios orientadores para o Turismo Arqueológico brasileiro, conforme detalhamento abaixo. Em todos os casos, os itens abordados foram avaliados e, quando necessário, adaptados para o Turismo Arqueológico:

Princípio I: Reconhecer a importância patrimonial da área. Esse é o primeiro passo para que um trabalho bem feito possa se realizar. Parte-se do princípio de que uma área de 
importância patrimonial, assim que identificada, precisa ser salvaguardada, mantendo-a em segurança.

Os gestores (públicos ou privados) de áreas com patrimônio arqueológico devem coletar e registrar o máximo de informações sobre a área, tantas quantas sejam necessárias para a compreensão da sua importância patrimonial.

As informações obtidas com os estudos arqueológicos serão fundamentais nessa etapa e ajudarão nessa compreensão. Ressalte-se que estes devem ser realizados por profissionais capacitados e contar, obrigatoriamente, com a autorização do IPHAN quando requererem coleta de materiais.

Complementarmente, a coleta de informações orais junto aos moradores das comunidades de entorno também é proveitosa e deve ser considerada sempre que possível.

Os resultados dos estudos devem ser amplamente divulgados, inclusive à própria comunidade local, que merece esse retorno, e aos guias e operadores de turismo, que precisam ter uma boa compreensão do valor da área com a qual estarão trabalhando.

Em última instância, é esperado que os turistas tenham curiosidade sobre a área que estão visitando e busquem informações sobre a cultura e a história do local. Para isso, entretanto, eles precisam ser estimulados.

Princípio II: Conservar os locais. A conservação dos locais é fundamental no turismo responsável. Isso significa uma preocupação a longo prazo. Deve-se lembrar que conservar não quer dizer proibir o uso e que não existe fórmula para a conservação dos sítios arqueológicos, cada caso possuindo especificidades e precisando ser analisado individualmente. As obrigações, portanto, serão identificadas de acordo com a importância da área. Neste ponto, além das informações científicas, é necessário coletar informações sobre outros fatores que podem afetar a integridade da área, dentre os quais as necessidades dos proprietários ou gestores, os recursos disponíveis para a conservação, os fatores externos e a condição física do local. A partir destes dados, deve-se desenvolver regulamentos que considerem o conceito do patrimônio arqueológico como patrimônio de toda a humanidade e não restrito a qualquer indivíduo ou nação. 
Todas as opções de uso (econômico, religioso, turístico etc.) devem ser identificadas, e os impactos de cada uma sobre a manutenção do significado do local devem ser considerados, bem como devem ser analisadas as possibilidades de usos conjuntos.

É importante estabelecer um plano de visitação que ajude a minimizar os impactos sobre os sítios, prevendo a criação de uma infraestrutura de apoio adequada à visitação, a interpretação dos recursos e o estabelecimento da capacidade de carga do local, tendo em vista o perfil e a quantidade dos visitantes que se pretende atrair.

Durante a operação, os guias de turismo devem estar familiarizados com todas as leis e regulamentos que regem o sítio arqueológico e devem segui-las em todos os momentos. Estes devem, também, certificar-se de que os visitantes seguirão todas as leis e regulamentos locais. Para isso, o tamanho do grupo precisa ser estabelecido conforme a possibilidade de manejo, sem prejuízo da possibilidade de controle do guia sobre os participantes.

Os turistas, por sua vez, devem respeitar os espaços previamente selecionados para visitação (sinalização, caminhos e cercas), evitar o contato com os vestígios ou as estruturas, nunca remover vestígios de um sítio arqueológico, e retornar com os seus pertences e o seu lixo. Também é muito importante que todos que presenciem atos de vandalismo em sítios arqueológicos relatem-nos às autoridades competentes.

Princípio III: Estabelecer parcerias. É muito difícil que uma experiência de turismo responsável seja concretizada sem que existam parcerias. Quanto mais grupos com interesses distintos estiverem trabalhando conjuntamente, maiores serão as probabilidades de um resultado positivo: além de isto incentivar a consideração de diversos aspectos, as responsabilidades estarão sendo partilhadas e, provavelmente, mais pessoas estarão se beneficiando com a atividade.

Para uma participação ativa de diversos grupos é necessário garantir que todos tenham acesso ao conhecimento necessário para a tomada de decisão. A prestação de informações ao público em geral é, portanto, um elemento importante na proteção integrada. 
Princípio IV: Investir nas pessoas e no lugar. Todos os envolvidos no Turismo Arqueológico devem compreender que o sítio está conectado diretamente às pessoas que hoje vivem na área.

Parte da renda obtida com a venda de pacotes, produtos e experiências que não tenham participação da comunidade local deve ser revertida em prol da melhoria das condições de vida da mesma e, consequentemente, resultar na proteção do patrimônio local.

Os gestores e operadores devem priorizar a formação de guias locais e encorajar a criação de outros produtos pelas comunidades, estimulando o desenvolvimento local.

Os turistas devem ser estimulados a contribuir com centros interpretativos, museus e outras associações que trabalham em prol da proteção do patrimônio local e incentivar outros visitantes a fazerem o mesmo. Além disso, devem certificar-se da conveniência de sua visita e combater operadores e guias mal intencionados.

Princípio V: Respeitar os direitos das comunidades locais. Alguns sítios arqueológicos, por exemplo, são considerados lugares sagrados pelas comunidades locais. Tal fato precisa ser identificado por gestores, operadores e guias para que costumes, tradições e/ou crenças locais não sejam desrespeitados. Em geral, recomenda-se muito diálogo com as comunidades, além da criação de normas de conduta que visem boas relações, como por exemplo, o estabelecimento do que 'pode' e 'não pode' ser feito naquele local (em termos de linguagem, contato físico, fotografia etc.).

Princípio VI: Desenvolver e oferecer negócios responsáveis. A responsabilidade dos negócios turísticos é o que garantirá a sustentabilidade da atividade e a satisfação dos turistas. É necessário realizar um planejamento, formulando objetivos, analisando os recursos e as limitações com as quais será necessário lidar. Os gestores devem estabelecer critérios para o funcionamento das zonas arqueológicas abertas à visitação pública, como o horário de funcionamento, a quantidade diária de visitantes, a quantidade de funcionários necessária para garantir a fiscalização da área e toda a infraestrutura de apoio à visitação, inclusive o acesso ao local e os estacionamentos. É importante, também, analisar o perfil dos potenciais usuários. 
Além disso, todos os envolvidos no desenvolvimento, na promoção e na distribuição do turismo devem ser incentivados a se capacitar para a atividade.

A responsabilidade em relação ao negócio vai além da responsabilidade apenas dos gestores da área. Os operadores devem colaborar com a qualificação das instalações e infraestrutura local, já que se beneficiam com a venda de pacotes turísticos para tais áreas. Isto possibilitará uma experiência melhor para o seu cliente e ajudará a preservar o local.

Princípio VII: Qualificar as experiências de visita. A experiência de visita a um sítio arqueológico é reforçada pela interpretação adequada do local e pelas experiências agregadas que permitem aos visitantes obterem uma melhor compreensão da importância patrimonial da área. Este princípio está fortemente atrelado ao primeiro princípio citado anteriormente, no sentido de que só há algo a se comunicar às pessoas, quando se está consciente de que o que está sendo mostrado é importante culturalmente. Para essa comunicação, devem ser definidos tanto as mensagens quanto os meios através dos quais estas mensagens serão transmitidas, além de definir o pessoal e as diversas estratégias necessárias para implantação da Interpretação Patrimonial. Esses meios podem incluir desde a simples disponibilização de sinalização adequada em trilhas e caminhos, à criação de materiais interpretativos diferenciados, museus ou centros interpretativos. Isso deve fazer parte de um planejamento interpretativo estratégico que precisa ser documentado e que deve servir de base para todas as etapas.

Os guias e operadores de turismo também devem estar cientes desse plano geral para a área e devem ser capazes de transmitir tais informações aos seus clientes, inclusive com o fornecimento de materiais suplementares (antes e/ou durante o passeio).

Deve-se ter em mente que a apresentação do patrimônio arqueológico ao público em geral é um meio essencial de promover a compreensão da sua importância e, consequentemente, da necessidade de sua proteção.

Princípio VIII: Promover os produtos. A promoção turística deve considerar a fragilidade dos sítios arqueológicos, assinalando as características especiais desse produto, fornecendo expectativas reais e informação responsável para os visitantes. A atividade de marketing deve ser iniciada ainda nas fases de pesquisa e diálogo, quando as necessidades dos clientes 
ou visitantes forem primeiramente consideradas e deve ser contínua até quando o desenvolvimento dos produtos. Considerações importantes nesse sentido são: conhecimento do público alvo, o apoio local, as mensagens fortes, uma publicidade oportuna e adequada, e, sobretudo, uma distribuição eficaz e adequada do material promocional.

Princípio IX: Monitore, Avalie, Reveja e Revise. Finalmente, destaca-se que qualquer plano de manejo ou gestão para áreas que possuam patrimônio arqueológico, bem como de qualquer atividade turística que se preze, deve ser submetido a reavaliações periódicas ou, melhor dizendo, a um monitoramento contínuo.

Esse último princípio traz para essa discussão mais um tema pertinente: o monitoramento. Existem muitos trabalhos que discutem a questão da criação e utilização de indicadores que auxiliem o monitoramento contínuo das atividades que estão sendo desenvolvidas, no que diz respeito à sustentabilidade como um todo, e alguns, em relação ao turismo sustentável.

(...) o objetivo de um indicador é apontar a existência de riscos, potencialidades e tendências no desenvolvimento de um determinado território para que, em conjunto com a comunidade, decisões possam ser tomadas de forma mais racional (TUNSTALL, 1994; GUIMARÃES, 1998). Portanto, indicadores, no sentido que estamos trabalhando, são um conjunto de sinais que facilitam a avaliação do progresso de uma determinada região na busca pelo desenvolvimento sustentável, sendo ferramentas cruciais no processo de identificação de problemas, reconhecimento dos mesmos, formulação de políticas, sua implementação e avaliação (GUIMARÃES E FEICHAS, 2009).

Diversas dificuldades podem ser apontadas para quem pretende utilizar indicadores de sustentabilidade (CORDEIRO et al., 2010), entre elas a própria construção dos mesmos, de modo que eles agreguem, de fato, aspectos considerados imprescindíveis para a promoção de mudanças na sociedade (GUIMARÃES e FEICHAS, 2009). Mesmo assim, nenhum dos autores consultados nega a importância do uso de indicadores como ferramentas para a avaliação da sustentabilidade de uma determinada área ou atividade, como é o caso do turismo. Como defendem Guimarães e Feichas (2009) "é importante que indicadores de sustentabilidade sejam incorporados ao cotidiano e ao planejamento das pessoas, gestores e organizações como o são os indicadores econômicos". 
É preciso, portanto, construir indicadores de sustentabilidade específicos para a atividade de Turismo Arqueológico, que ajudem no monitoramento da mesma. Reconhece-se, dessa maneira, que ao implantar o Arqueoturismo em um local, a prática dos princípios listados anteriormente precisa ser constantemente avaliada e a detecção da ausência no cumprimento de algum deles deve ser motivo para a revisão dos caminhos adotados. Daí a importância em se detalhar e expandir cada vez mais esses princípios.

\title{
II. 4. A INTERPRETAÇÃO dO PATRIMÔNIO (IP) À FAVOR DO TURISMO ARQUEOLÓGICO.
}

\begin{abstract}
"La interpretación es el proceso de comunicación que pretende que el visitante descubra el significado de cosas, lugares, personas y acontecimientos. Es más que información, es más que educación... implica ayudar a que la gente cambie la forma que tiene de verse a ella misma y al mundo, a través de una mayor comprensión de si misma y del mundo que le rodea" (John Macfarlane)
\end{abstract}

Como discutido até agora, a gestão do patrimônio deve estar pautada, obrigatoriamente, sobre três pilares: investigação, conservação e difusão (MARTín, 2002). Quanto à difusão, acredita-se que o Brasil concentre seus esforços muito fortemente na Educação Patrimonial. Por isso, neste momento, considera-se oportuno apresentar a Interpretação Patrimonial como uma ferramenta que pode, também, auxiliar no cumprimento de todos os princípios anteriormente listados.

Primeiramente, deve-se justificar a escolha da Interpretação Patrimonial em contraposição à tão utilizada Educação Patrimonial. Pensando na forma em como o homem percebe o ambiente, Okamoto (1996: 83) afirma que os "nossos sentidos estão obliterados pela educação parcial, que dá ênfase ao conhecimento lógico racional. Em função disto, deixamos de ter os sentidos apurados". Segundo ele, os cientistas, em geral, seguem o postulado de Galileu contra a consideração de que propriedades não quantificáveis, como o som, a cor, o 
sabor ou cheiro, deveriam ser entendidas como projeções mentais e, portanto, fora da alçada das ciências. Citando outros autores, ele afirma que isso teria provocado inúmeras mudanças na nossa forma de perceber o mundo, já que a experiência teria sido expulsa do domínio científico.

Como ponto de partida, entende-se que a lógica da difusão do conhecimento precisa ser modificada e que a utilização das propriedades sensoriais citadas acima deve ser promovida em situações de aprendizado, já que a base do entendimento humano da natureza é a interação com o entorno ou, dito de outra maneira, todo conhecimento se baseia em percepções sensoriais e na capacidade de transmitir essas experiências a outros seres humanos.

Além disso, ao discordar que um bem público permaneça desconhecido da população e desejar que as investigações arqueológicas tenham seus resultados divulgados, resta então defender que a aproximação da sociedade com esses bens utilize estratégias que vão além da informação. Como coloca Padró Werner (2002: 03):

Hoy en día una persona puede recibir o disponer de mucha información sobre un patrimonio o sobre un territorio determinado, pero normalmente le faltan recursos para poder aprovecharla. De ahí surge la necesidad de crear dispositivos que "den sentido" a los testimonios culturales y naturales de un territorio y nos ayuden a asimilar lo que vemos. Mediante la interpretación no se pretende simplificar o vulgarizar la información, sino ofrecer claves y ayudas para captar aspectos esenciales.

Tomando como base o patrimônio arqueológico brasileiro, um sítio cerâmico na Amazônia diz muito pouco se não for interpretado para os visitantes, assim como um sambaqui, à primeira vista, é apenas um grande morro de conchas e areia, e gravuras rupestres são apenas desenhos em pedras. Sem o estímulo à curiosidade, e sem a interpretação, o público não compreende o significado desse patrimônio. Dessa situação resultam atitudes e comportamentos indesejados frente ao patrimônio, dentre os quais o recolhimento e a compra de materiais, bem como as pichações, que são, possivelmente, os mais comuns no Brasil. Entretanto, cada exemplo de patrimônio brasileiro conhecido possui um imenso potencial interpretativo contido nas investigações científicas. Porém, como não são os dados científicos puros que interessam às pessoas em geral, explicar datas e fatos nem sempre é suficiente, embora seja o que frequentemente acontece. 
$\mathrm{Na}$ arqueologia, as datações costumam chamar atenção desde que sejam bastante antigas. Não é incomum que uma pessoa receba uma informação de que há mil anos algo acontecia e que a repasse falando em milhões (SCHANN, 2006). Aparentemente, quanto mais antigo, maior a importância que as pessoas dão a determinado objeto ou fato histórico. Os arqueólogos, de certa forma, têm responsabilidade na manutenção desse pensamento, já que se utilizam das datas mais antigas (sempre que elas existem ou podem existir) para atrair a atenção para sua área de pesquisa.

Outro fato muito comum é a visitação de museus e exposições onde podem ser observados objetos acompanhados de etiquetas com um forte aspecto acadêmico que, considerando apenas as necessidades de seus executores, ignoram as necessidades do público que terá acesso a elas (RUIz, 2002). Por exemplo, se uma etiqueta nomeia um objeto como 'agulha', o público confronta-se com uma palavra que the remete a algo que, normalmente, faz parte da sua vivência e pressupõe a função do objeto em questão. Por outro lado, se a etiqueta refere-se a algo chamado 'tortual', é quase certo que muitos sairão sem a compreensão da sua função. Um visitante mais interessado pode pesquisar o significado do termo, no mesmo momento, se possuir um celular com acesso à internet, mas, mesmo assim, ainda poderá sair sem obter informações sobre o objeto pesquisado. Experimentou-se digitar 'tortual' no Google e no Yahoo, dois tradicionais sites de busca na Internet, e, nas duas primeiras páginas de cada um, nada se referia ao objeto em questão. Da mesma forma, de nada adianta criar uma infraestrutura física de acesso a um sítio arqueológico, mas não possibilitar uma compreensão desse espaço. Quem apresenta um objeto ou sítio arqueológico dessa maneira parece esquecer que:

El patrimonio arqueológico y, en menor medida pero también, el etnológico, se encuentran fuera de época y de lugar, es decir, descontextualizados, y requieren un fuerte tratamiento museográfico para que el gran público los entienda, pero no sólo en lo que respecta a grandes planteamientos o a criterios generales, sino también en los pequeños pero múltiples detalles que pueden formar una barrera insalvable entre el visitante y el contenido del museo o lugar que se visita (RUIz, 2002: 04).

Isso é importante de ser avaliado porque, embora durante suas vidas as pessoas tenham acesso a informações sobre o patrimônio arqueológico (na escola, em jornais e revistas, na internet etc.), é no momento em que elas confrontam-se fisicamente com ele que sensações intelectuais, afetivas e estéticas têm mais chances de serem provocadas e estimuladas. 
Como essa pode ser uma chance única, ela não pode ser desperdiçada (MIRANDA, 2004), seja em uma exposição, em um museu ou em um sítio arqueológico.

Interpretation is especially important when the significance of a resource isn't immediately obvious to visitors - for instance, archeological sites where physical evidence of the past is hidden underground. Interpretation is also crucial in helping people understand cultural traditions that are unfamiliar to them. If your resource is a great example of local heritage, and no one knows it, it's hard to justify its authenticity. Interpretation makes that connection for visitors ${ }^{50}$ ( $(\mathrm{CH}$ e YCH, 2007).

É por isso que muitos profissionais, no mundo todo, baseiam seus trabalhos nos princípios da IP. Entretanto, no Brasil, ela ainda não é bem compreendida e corretamente desenvolvida. Em alguns textos brasileiros que tratam da IP, percebe-se o uso do termo apenas como um jargão e, enquanto em muitos países existem organizações ${ }^{51}$ voltadas à discussão e aprimoramento das técnicas interpretativas, bem como à sua difusão, no Brasil, pouco se fala no assunto.

\section{II.4.1. HISTÓRICO, PRINCÍPIOS E PRÁTICA DA INTERPRETAÇÃO PATRIMONIAL.}

Conta-se que a interpretação surgiu nos museus e parques nacionais americanos. Diversos artigos (p. ex. PADRó WeRnER, 2002) apontam Freeman Tilden como o "pai” da Interpretação

\footnotetext{
${ }^{50}$ A interpretação é especialmente importante quando o significado de um recurso não é imediatamente óbvio para os visitantes - por exemplo, no caso de sítios arqueológicos onde a evidência física do passado encontra-se escondida no subsolo. A interpretação é também crucial para ajudar as pessoas a compreenderem as tradições culturais com as quais não estão familiarizadas. Se o seu recurso é um grande exemplo do patrimônio local, e ninguém sabe disso, é difícil justificar a sua autenticidade. A Interpretação Patrimonial faz essa conexão para os visitantes [Tradução: Luciana M. Guimarães].

51 O site da Scottish Interpretations Network (SIN) apresenta algumas dessas organizações (http://www.scotinterpnet.org.uk). Acesso em: fev./2010. Para aprofundamento no tema, buscar na Internet:

- Asociación para la Interpretación del Patrimonio (AIP) - Spanish Association for Heritage Interpretation;

- $\quad$ Association of Heritage Interpretation (UK) - The body for professional interpreters in the UK;

- Interpret Europe - An international network bringing together persons and organisations with an interest in Heritage Interpretation;

- Interpret Scotland - An inter-agency organisation to improve the quality of interpretation in Scotland;

- Interpretation Australia Association - A national membership-based organisation dedicated to the advancement of the profession of heritage interpretation;

- Interpretation Canada - A volunteer-run professional association of contributing members;

- National Association for Interpretation (USA) - A professional association dedicated to the advancement of the profession of interpretation.
} 
Patrimonial, devido à publicação do livro Interpreting Our Heritage. Todavia, Russel Dickenson, no prefácio da quarta edição deste livro (TILDEN, 2007), conta que Dr. Harold Bryant, superintendente do Grand Canyon National Park entre os anos 1940 e 1954, é tido por muitos como o principal motor da interpretação neste parque, desde 1920 . No mesmo período, Dickenson afirma, outros guardas-parques deixavam visitantes encantados e agradecidos por suas erudições e apresentações dramáticas. Porém, a expansão do serviço, as novas contratações de pessoal, a aposentadoria de pessoas chaves para o processo interpretativo e a nova liderança nas décadas de 1950 e 1960, trouxeram à tona a necessidade de revisar o programa e, nesse contexto, destacou-se Tilden.

Segundo Bruce Graic (TILDEN, 2007), Interpreting Our Heritage é o resultado de inúmeras viagens realizadas por Tilden pelos parques americanos. Apesar da idade (a primeira publicação data de 1957), este livro mantém-se bastante atual. Os princípios ali apresentados continuam servindo de base a todos os interessados em transformar a relação das pessoas com seus meios. São eles (TILDEN, 2007: 34-35):

1. Any interpretation that does not somehow relate what is being displayed or described to something within the personality or experience of the visitor will be sterile.

2. Information, as such, is not interpretation. Interpretation is revelation based upon information. But they are entirely different things. However, all interpretation includes information.

3. Interpretation is an art, which combines many arts, whether the materials presented are scientific, historical or architectural. Any art is in some degree teachable.

4. The chief aim of interpretation is not instruction, but provocation.

5. Interpretation should aim to present a whole rather than a part and must address itself to the whole man rather than any phase.

6. Interpretation addressed to children (say, up to the age of twelve) should not be a dilution of the presentation to adults but should follow a fundamentally different approach. To be at its best it will require a separate program ${ }^{52}$.

Abordagens mais recentes entendem a IP como uma disciplina que possui uma variedade de pautas e diretrizes metodológicas para a comunicação e para a apresentação do patrimônio

\footnotetext{
52 1. Qualquer forma de interpretação que não relacione o que está sendo mostrado ou descrito com algo presente na personalidade ou na experiência pessoal do visitante será estéril; 2. A informação em si não é interpretação. A interpretação é a revelação baseada em informação. Mas elas são totalmente diferentes. No entanto, toda interpretação inclui informação; 3. A interpretação é uma arte que combina muitas artes, ainda que os materiais apresentados sejam científicos, históricos ou arquitetônicos. Toda arte pode, em algum nível, ser ensinada; 4. O objetivo principal da interpretação não é a instrução, mas a provocação; 5. A interpretação deve objetivar apresentar o todo, ao invés de uma parte isoladamente, e deve dirigir-se a todos, sem priorizar qualquer fase da vida humana; 6. A interpretação voltada às crianças (menores de doze anos) não deve ser uma diluição do que é feito para adultos e sim, seguir uma abordagem fundamentalmente diferente. Para que os melhores resultados sejam alcançados, serão necessários programas específicos [Tradução: Luciana M. Guimarães].
} 
in situ ao público e para a transmissão de uma mensagem impactante que, se possível, transcenda a visita e incuta atitudes e comportamentos positivos em relação ao patrimônio e o seu entorno social (MARTín, 2003). Para que não haja confusão, Martín explica a terminologia em diferentes atuações:

En investigación, la interpretación es el estudio y la generación de una narrativa que el especialista realiza sobre el vestigio arqueológico o histórico que les confiere sentido y que permite integrarlos en el recorte histórico del que formaron parte.

En conservación, la interpretación es el proceso analítico que permite tomar decisiones a la hora de intervenir sobre el bien sin alterar las manifestaciones materiales que lo definen.

En difusión, la interpretación es:

- el arte de revelar in situ el significado del legado natural o cultural al público que visita esos lugares en tu tiempo de ocio.

- ofrecer al público una ilustración del legado natural y cultural a través de una narrativa que les confiera sentido y que les permita integrarlos en el momento histórico del que formaron parte.

A definição "a arte de revelar 'in situ' o significado do legado natural e cultural ao público que visita esses lugares em seu tempo livre" é utilizada pela Asociación para la Interpretación del Patrimônio (AIP), da Espanha. Deve-se observar que essa definição enfatiza: (i) primeiramente, o público, o que significa considerar qualquer pessoa que esteja visitando o local, incluindo a própria comunidade e, (ii) em seguida, o tempo livre em que esse público se encontra. O fato de a interpretação estar voltada a pessoas em seu tempo livre faz com que exista uma diferenciação clara entre os programas de IP e os tradicionais programas educativos. Há mais de dez anos, no primeiro Boletín de Interpretação del Património, Francisco Guerra (1999: 3-4) esclareceu essa diferença de forma bastante clara:

Lo queramos o no, el destinatario de la interpretación está constituido exclusivamente - y por definición - por el público general: una audiencia no cautiva que no está sujeta a ningún tipo de obligación cuando se enfrenta a una bien natural o cultural, y cuya única expectativa de provecho es de carácter espiritual o estético, sin que exista ningún tipo de incentivo extraordinario: aprobar exámenes, recibir algún punto por un trabajo excelente... No es, por tanto, el caso de, por ejemplo, los grupos escolares que acuden a visitar un espacio protegido, acompañados habitualmente de su profesor, y cuyo objetivo principal es conocer el espacio. Si bien es cierto que pueden emplearse técnicas interpretativas en el tratamiento de éste y otros colectivos, la realidad es que los objetivos de dichos programas, así como las actividades a ellos destinadas no pueden llamarse verdaderamente interpretación.

Embora ao longo desses anos a compreensão tenha evoluído e as técnicas interpretativas estejam sendo utilizadas nos mais distintos contextos, inclusive em contextos educativos, em museus, exposições e centros de visitantes, conforme explicitam Morales e Pastor (2002), essa diferenciação ainda precisa estar clara. 
De forma mais ampla, a utilização das técnicas de Interpretação Patrimonial pode ser traduzida em acessibilidade. Neste sentido, acessibilidade extrapola a questão da possibilidade de acesso, no sentido físico, para uma acepção mais abrangente da palavra, que inclui, justamente, a garantia de uma experiência de desfrute desse patrimônio por qualquer pessoa e em condições de qualidade (VÁzQUEZ, 1999).

A Interpretação Patrimonial prega que, mais do que estimular a curiosidade, deve-se satisfazê-la, e chegar ao coração tanto quanto à razão. Por isso, ela também é vista como " $a$ arte de traduzir para uma linguagem amena e compreensível o que talvez só conheçam os especialistas sobre determinados aspectos do patrimônio" (MIRANDA, 2004). Essa tradução não é algo simples de ser feito e alguns pontos devem ser considerados para que se alcance um bom resultado (MORALES, 2001):

1. Para el conocimiento (o sea, ¿qué queremos que la gente sepa?);

2. Para la afectividad (es decir, ¿qué queremos que la gente sienta?);

3. Para las actitudes y/o comportamientos (¿qué queremos que la gente haga? 0 no haga, porque el "no hacer" también es un comportamiento).

Refletindo sobre essas perguntas, chega-se a diversas experiências ou serviços que podem ser oferecidos aos visitantes. Para o NSW Heritage Office (2005), da Austrália, "the connections between people and natural and cultural heritage are often expressed through art, music, literature, dance, food and other creative works and traditions ${ }^{\prime \prime 53}$, sendo estas formas tradicionais de interpretação.

Veloso e Cavalcanti (2007) sugerem que o uso da interpretação em relação ao patrimônio arqueológico pode acontecer das seguintes formas:

- Rotas temáticas;

- Espetáculos e celebrações de recreação histórica de caráter mais participativo;

- Apresentações de gastronomia como a gastronomia de povos antigos;

- Possibilidades de se alojar em hotel que conserva vestígios arqueológicos;

- Festivais de teatro clássico em sítios arqueológicos;

- Cine arqueológico;

- Comemorações associadas a personagens e acontecimentos;

- Sítios arqueológicos integrados às cidades Patrimônio da Humanidade;

- Arqueologia industrial que pode englobar visitas a minas e complexos minerários;

- Viagens temáticas;

- Visitas subaquáticas;

${ }^{53}$ Os vínculos entre as pessoas e os patrimônios natural e cultural expressam-se, normalmente, por meio da arte, da música, da literatura, da dança, da culinária e de outras obras e tradições criativas [Tradução: Luciana M. Guimarães]. 
- Desenvolvimento, por empresas privadas de reconstruções históricas, de gostos, sabores e odores de qualquer época ou de transporte no tempo;

- Participação monitorada em escavações arqueológicas.

Outras opções seriam os museus e exposições (SCATAMACCHIA, 2005), trilhas, caminhadas, rotas, tours guiados (MurTA e Goodey, 2001; MurTA e Albano, 2002), museus de sítio e parques arqueológicos (Veloso e CAVAlCANTI, 2007). Ou seja, há uma infinidade de formas e mídias possíveis para dar suporte ao uso turístico do patrimônio arqueológico, que, quando bem planejadas e fundamentadas, ajudam a promover a aproximação de um público bastante amplo e diversificado com o mesmo. O patrimônio, como assinalado anteriormente, deve ser conhecido e amado se se pretende que seja preservado

A IP serve, portanto, como método para desenvolver produtos e serviços focados no patrimônio, preocupados com a sua conservação, alinhando-se, desse modo, aos preceitos de desenvolvimento sustentável (PADRó WERnER, 2002). O Brasil, ainda hoje, dispõe, basicamente, de museus, exposições temporárias e alguns outros espaços de visitação, que, em geral, encontram-se bastante carentes de interpretação. Por isso, não se justifica fazer observações detalhadas sobre as opções citadas acima. Ao invés disso, alguns exemplos internacionais serão apresentados.

Um exemplo de aproveitamento excepcional do patrimônio acontece na Suíça, em um sítio arqueológico romano, denominado Augusta Raurica (Ilustração II.5). No local, há, além de um museu tradicional, uma típica casa romana, com representações de pessoas e com objetos reais de uso cotidiano e comercial encontrados nas escavações. Além disso, existe uma fazendinha onde as pessoas podem ver de perto animais que já eram criados na época romana e, ainda, um calendário de eventos, incluindo visitas guiadas, palestras e um festival romano (Ilustração II.6). É possível percorrer uma trilha interpretativa autoguiada, seguindo os painéis, todos em três línguas, com perguntas que serão respondidas no próximo painel, estimulando, assim, o seu percurso completo (Ilustração II.7). 

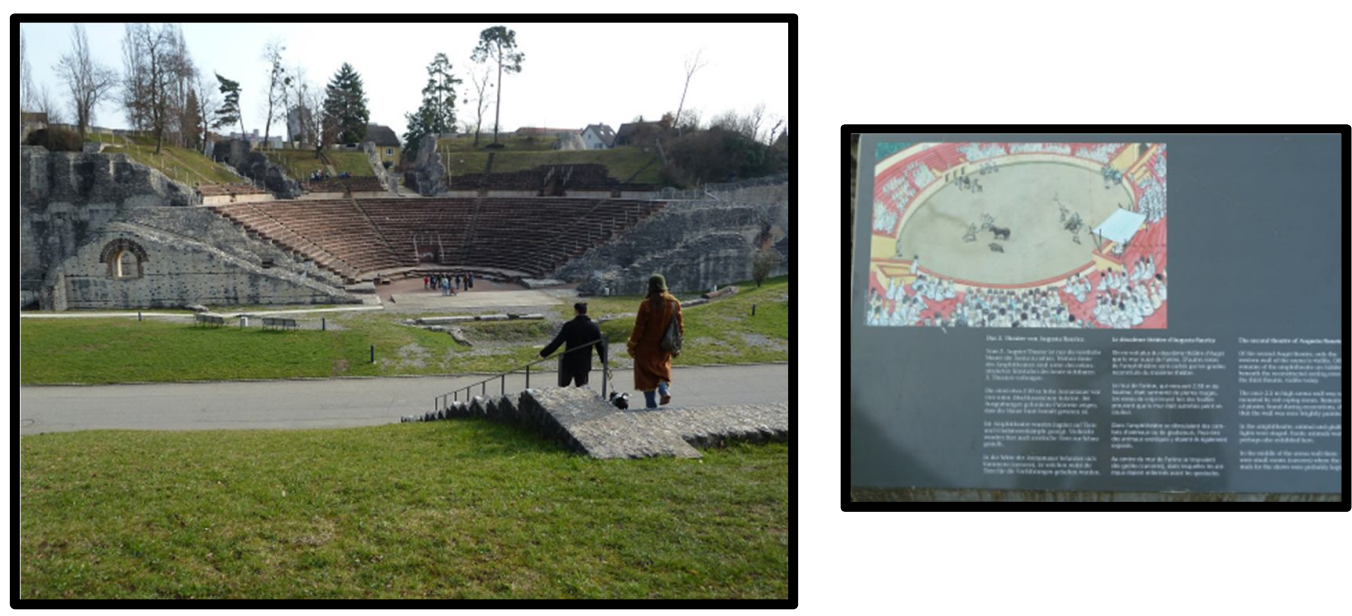

Ilustração II.5: Augusta Raurica. Teatro Romano e sua ilustração e interpretação em um painel, no detalhe (FotografiAs: Gustavo Accacio e Adriana Guimarães, 2011).
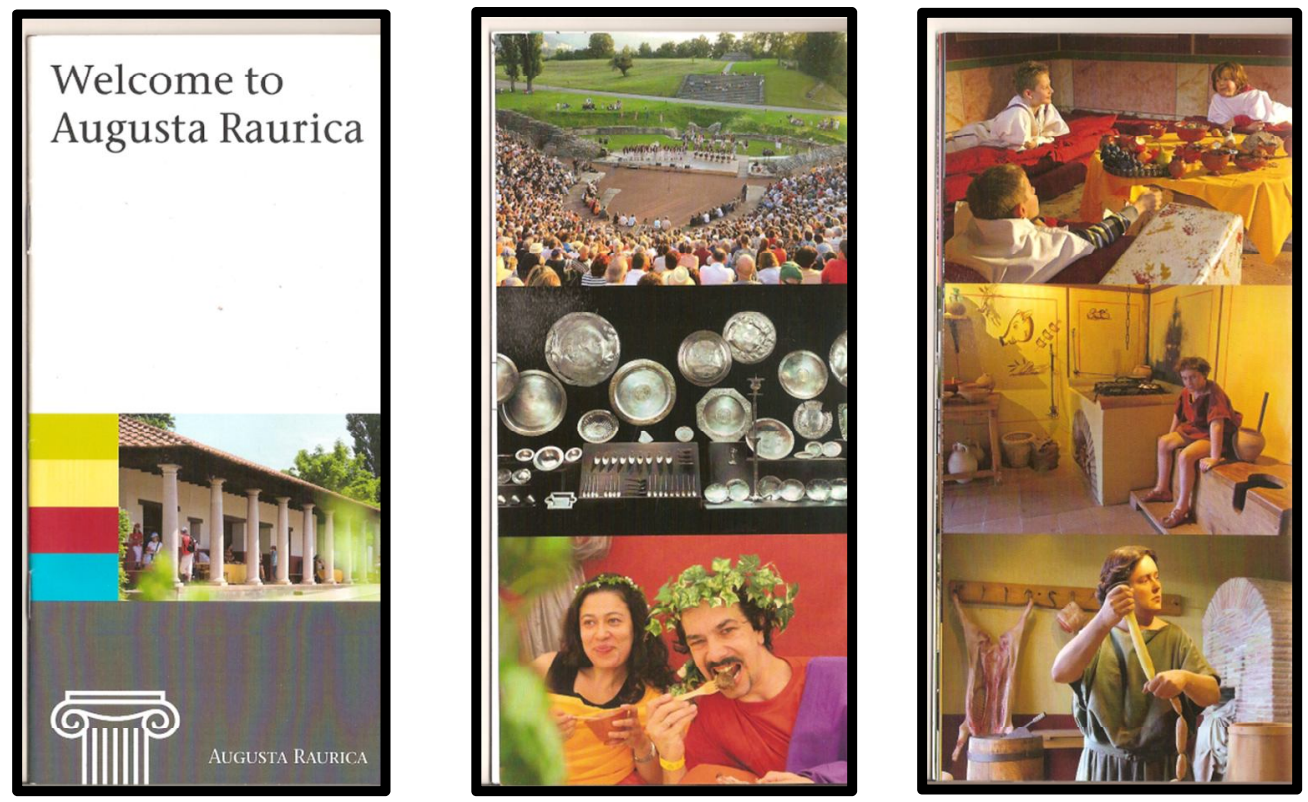

Ilustração II.6: Augusta Raurica. Folder promocional: capa (à esquerda) e páginas internas ilustradas (à direita) mostrando o festival romano, pessoas caracterizadas e o interior da Roman House. 


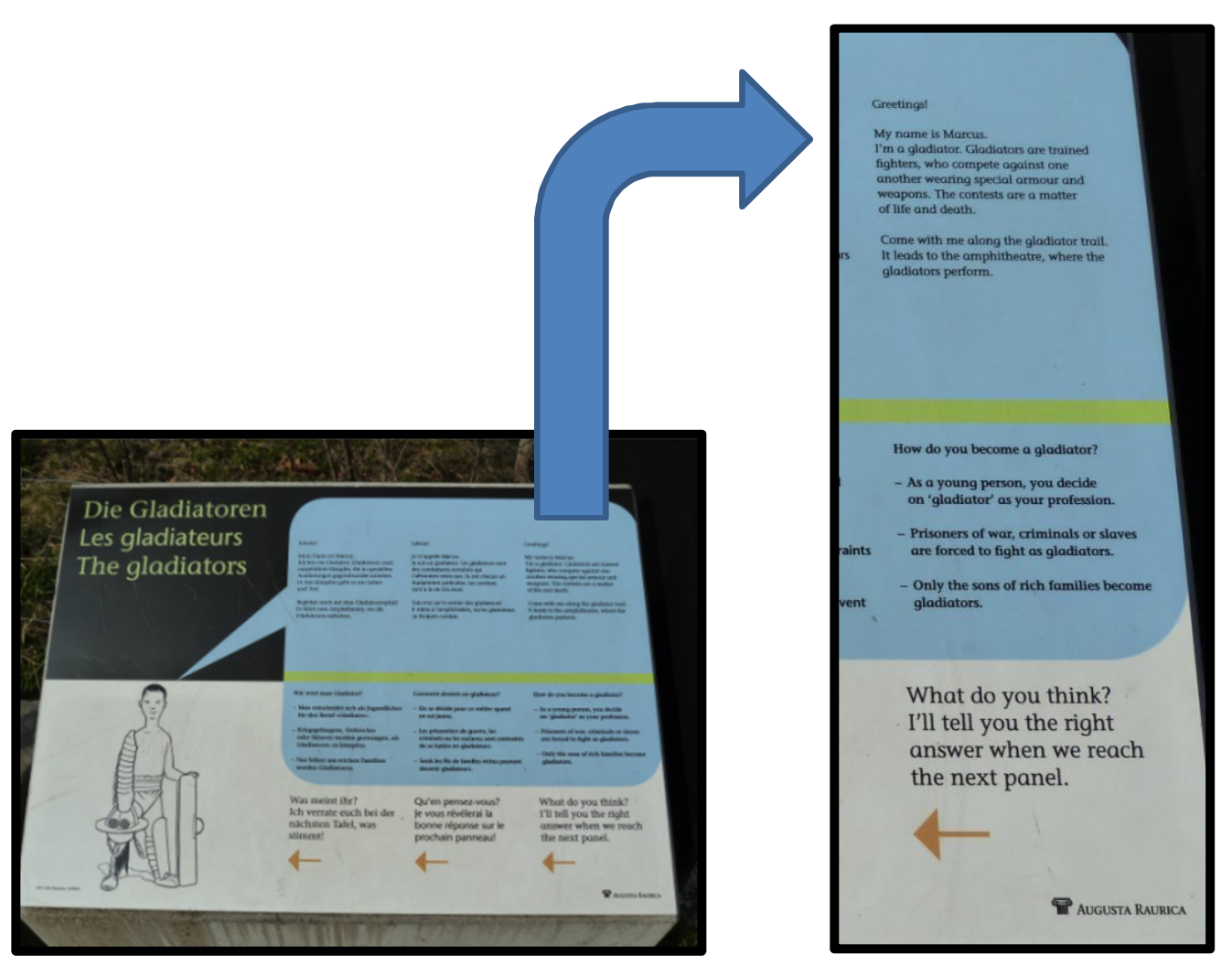

Ilustração II.7: Augusta Raurica. Painel da trilha interpretativa, com perguntas que serão respondidas na próxima placa (FotogRAFIAS: Adriana Guimarães, 2011).

Na Itália, em muitos lugares, opta-se pelo uso de equipamentos de áudio guia como meio para interpretar o patrimônio. É o caso, por exemplo, de Roma, no complexo arqueológico que inclui o Fórum Romano, o Coliseu e o Palatino. Ao optar pelo áudio guia, o visitante recebe um mapa que o ajuda a se localizar nos pontos onde receberá as devidas informações do que está sendo observado (Ilustração II.8). O mesmo sistema também pode ser contratado em Veneza, onde a área coberta pelo áudio guia permite o deslocamento por quase toda a cidade antiga. 

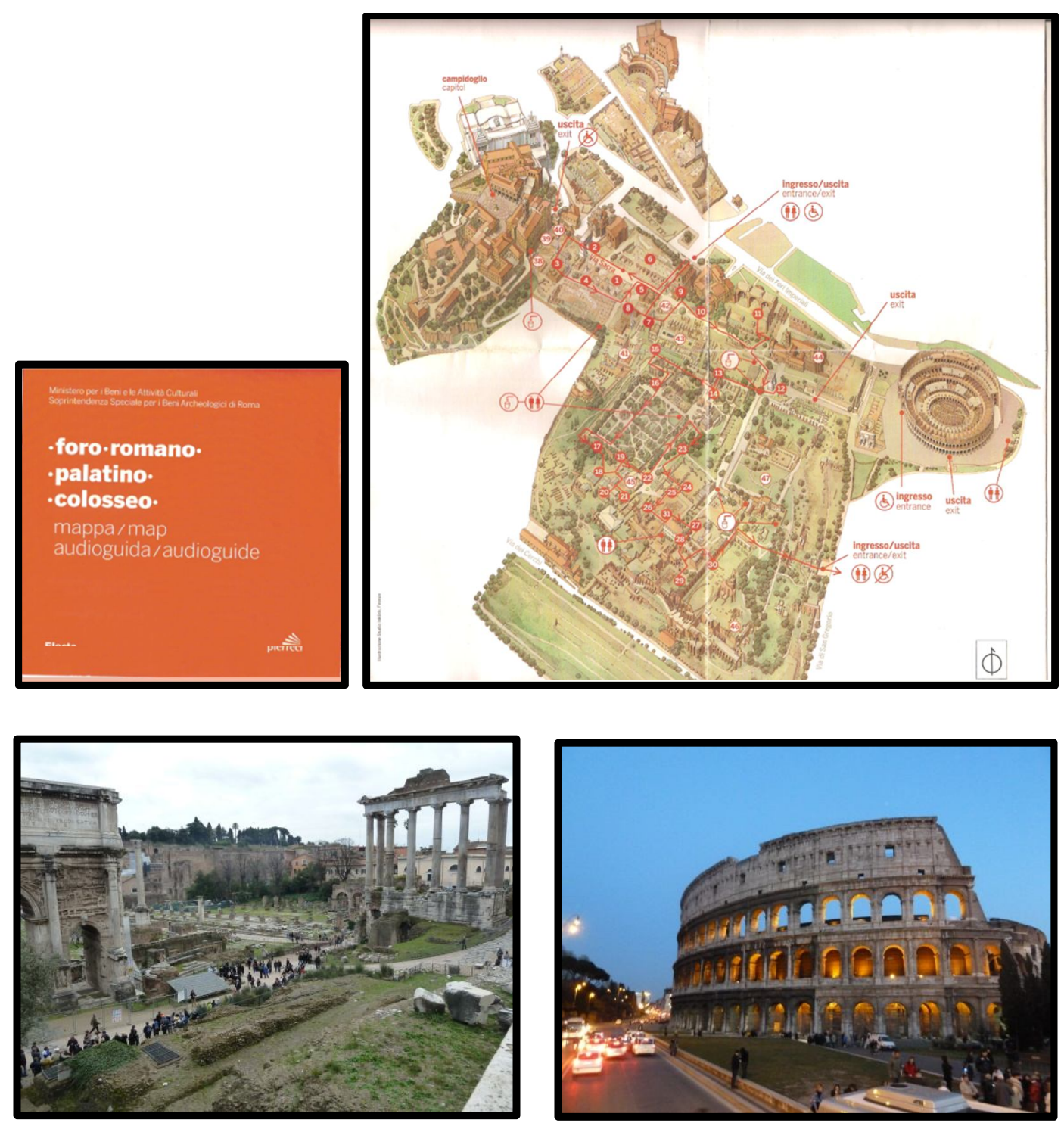

Ilustração II.8. Roma. Complexo Arqueológico Foro Romano e Colosseo (abaixo) (FotografiAs: Adriana Guimarães, 2011). Capa do mapa do áudio guia (acima à direita) e parte interna onde os pontos de interesse estão destacados (acima à esquerda).

No México, contrariando a ideia de que a monumentalidade é suficiente para sustentar o Turismo Arqueológico, há vários atrativos muito bem preparados para interpretar o que está sendo visto. Um exemplo disso são os museus de sítio, que abrigam coleções locais, apoiam a continuidade das pesquisas, e utilizam-se de diversos meios interpretativos para comunicar o patrimônio. Além destes, foram criadas estruturas para visitação dos sítios com a demarcação de trilhas e implantação de serviços de guias especializados, como acontece na Zona Arqueológica de Palenque, no estado de Chiapas. 
Palenque é um dos sítios arqueológicos mais importantes do México, considerado pela UNESCO como Patrimônio Cultural da Humanidade. As majestosas edificações locais e a grandeza do sítio destacam-se na paisagem. O sítio está demarcado por trilhas com placas informativas e interpretativas sobre o percurso que está sendo feito (Ilustração II.9). Cabe destacar que, em todos os sítios visitados no país, percebeu-se que a programação visual das placas informativas e painéis interpretativos seguem a mesma linha, tornando-se, desse modo, bastante familiar ao usuário.
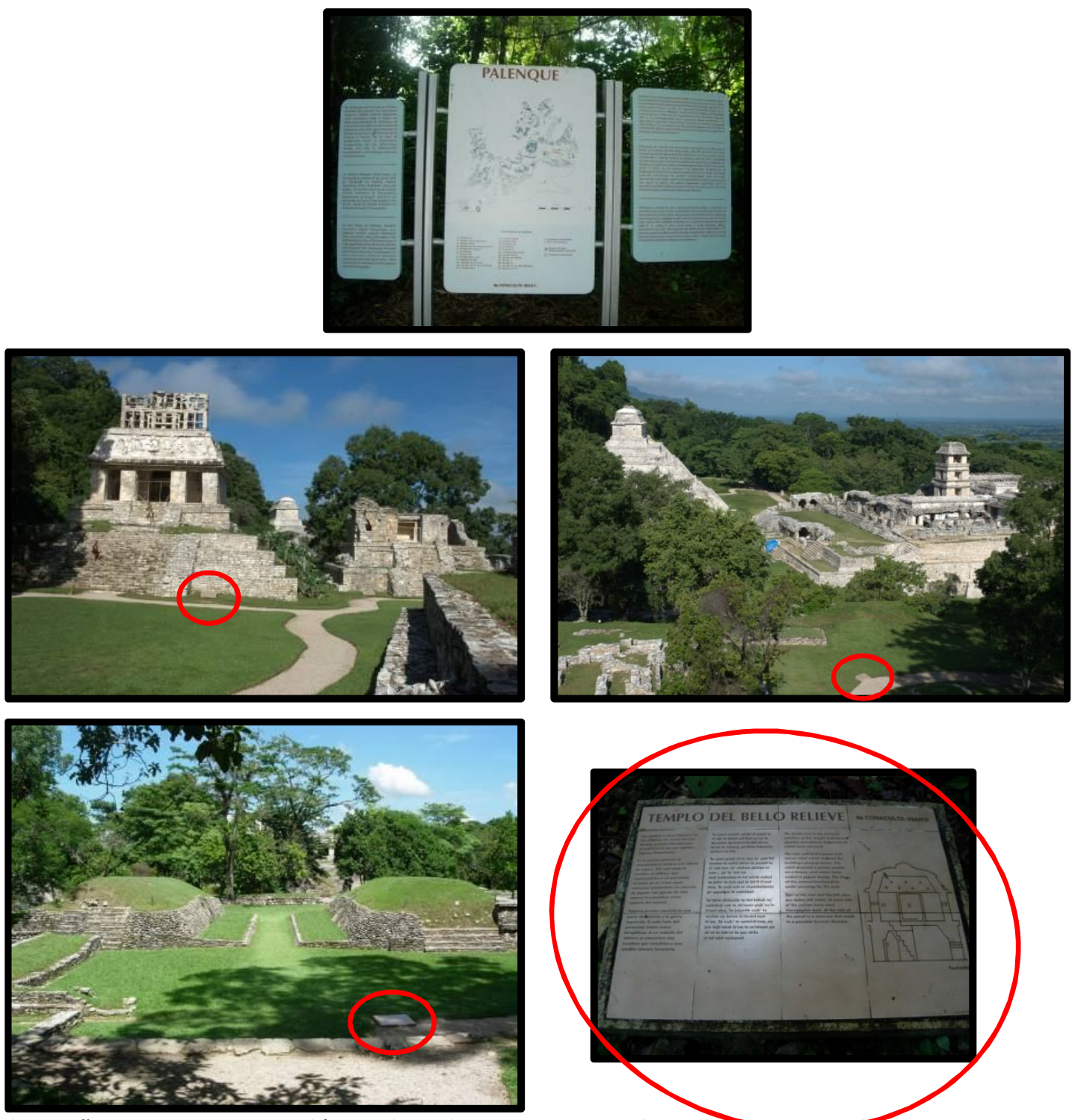

Ilustração II.9: Zona Arqueológica de Palenque. Sistema de trilhas com as placas interpretativas destacadas nas imagens e no detalhe (à esquerda) (FotografiAs: Gustavo Accacio, 2009). 
Outro exemplo diferenciado, nesse mesmo país, encontra-se no parque Xcaret, próximo a Cancun. Definido como um parque ecológico e arqueológico, este parque dedica-se à difusão da cultura maia e mexicana em geral, assim como à preservação do ambiente, conservando em sua área espécies animais e vegetais, bem como ruínas arqueológicas e uma igreja católica, tida como uma das construções espanholas mais antigas do México ${ }^{54}$. 0 local dispõe de atrações como aquários, zoológicos, rios subterrâneos, shows, entre outras. Em alguns espaços, é possível acompanhar, durante o dia, exibições de danças e representações de rituais e/ou cerimônias maias (Ilustração II.10). Ao final do dia, realiza-se a encenação México Espectacular, contando a história do país. A primeira parte do show fala sobre o México antigo, mostrando, por exemplo, a reunião de líderes indígenas com suas equipes para iniciarem o jogo com a bola de borracha. Este jogo, cujo nome no dialeto original é Pok ta' pok, "consists on the luminous team players hitting the ball with their hips, elbows and knees looking for plays that the opponent can't respond, and with this get the light triumph and the birth of the sun, meanwhile the other team is looking for the dark triumph" (GonZÁLEZ et al., 2011) ${ }^{55}$ (Ilustração II.11). Qualquer colocação que possa ser feita em relação à autenticidade dessas representações torna-se pequena frente à sensação transmitida pelo espetáculo, principalmente se a pessoa já visitou diversos museus e sítios no país e pôde, em quase todos, ver um dos discos de pedra equivalentes ao "gol" do futebol atual, ficando curiosa sobre como é possível passar por ali uma bola de borracha pesada, que deve ser jogada com os quadris. Além deste, também é encenado o jogo com a bola de madeira em chamas (Uarhukua), praticado há cerca de 3.000 anos no estado de Michoacán. A apresentação do encontro dos indígenas autóctones com os europeus, mostra da chegada dos espanhóis, as lutas com os nativos e a evangelização destes, até a combinação dos dois povos. O espetáculo continua, partindo para a apresentação da cultura de distintas partes do México atual. Destaca-se que a caracterização dos atores (cerca de 300) é cuidadosa, remetendo imediatamente aos objetos vistos em museus. Analisando comentários de turistas em um site de viagens na internet, percebeu-se que, de 1402 (mil quatrocentos e dois) comentários, 1090 (mil e noventa) classificaram o parque como

\footnotetext{
${ }^{54}$ Informações colhidas no site: http://www.holboxtravel.com.mx/holbox/tours-en-holbox/eco-parquesxcaret.html. Acesso: mar./ 2012.

${ }^{55}$ No artigo citado, os autores descrevem o desenvolvimento de um jogo virtual tendo como base o Pok ta' Pok. O jogo virtual proposto por esses autores recria partidas a partir de técnicas modernas de modelagem 3D, animação etc. e poderá ser jogado online por até dois jogadores (GonZÁLEZ et al., 2011).
} 
excelente ou muito bom e, quando os comentários se referiam ao show noturno, os turistas elogiavam-no, mostrando-se satisfeitos e usando expressões como "maravilhoso" e "imperdível".
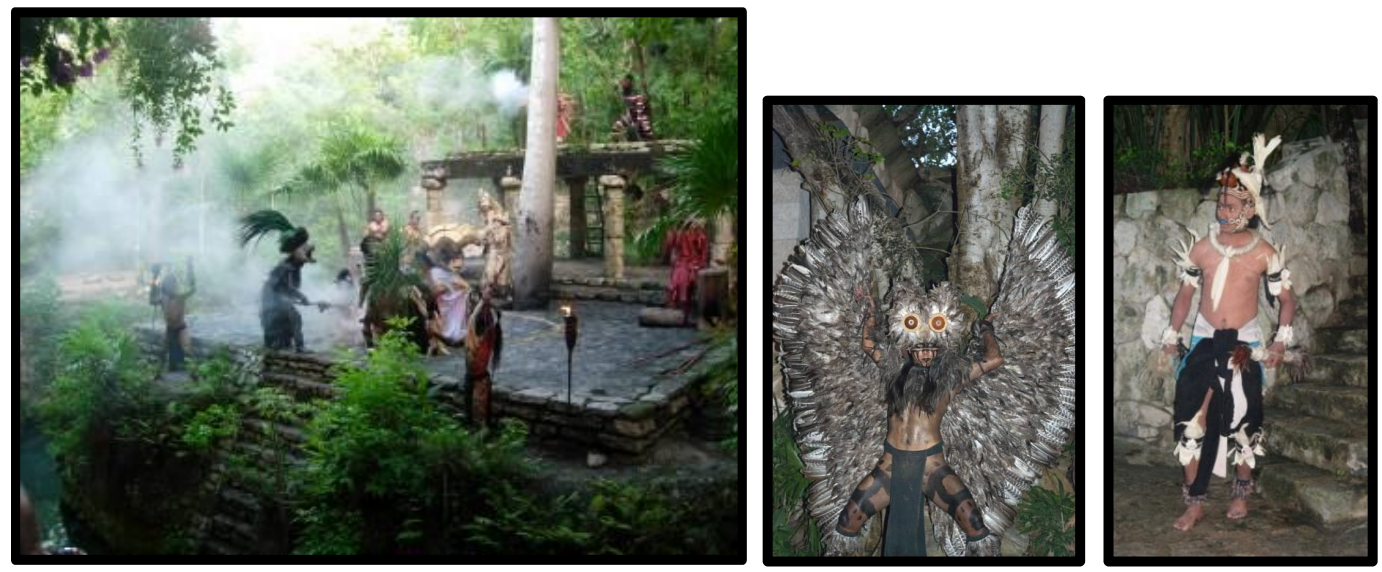

Ilustração II.10: Xcaret. Encenações diurnas (à esquerda). Atores com vestimentas baseadas na iconografia Maia (à direita) (FotografiAs: Adriana Guimarães, 2009).
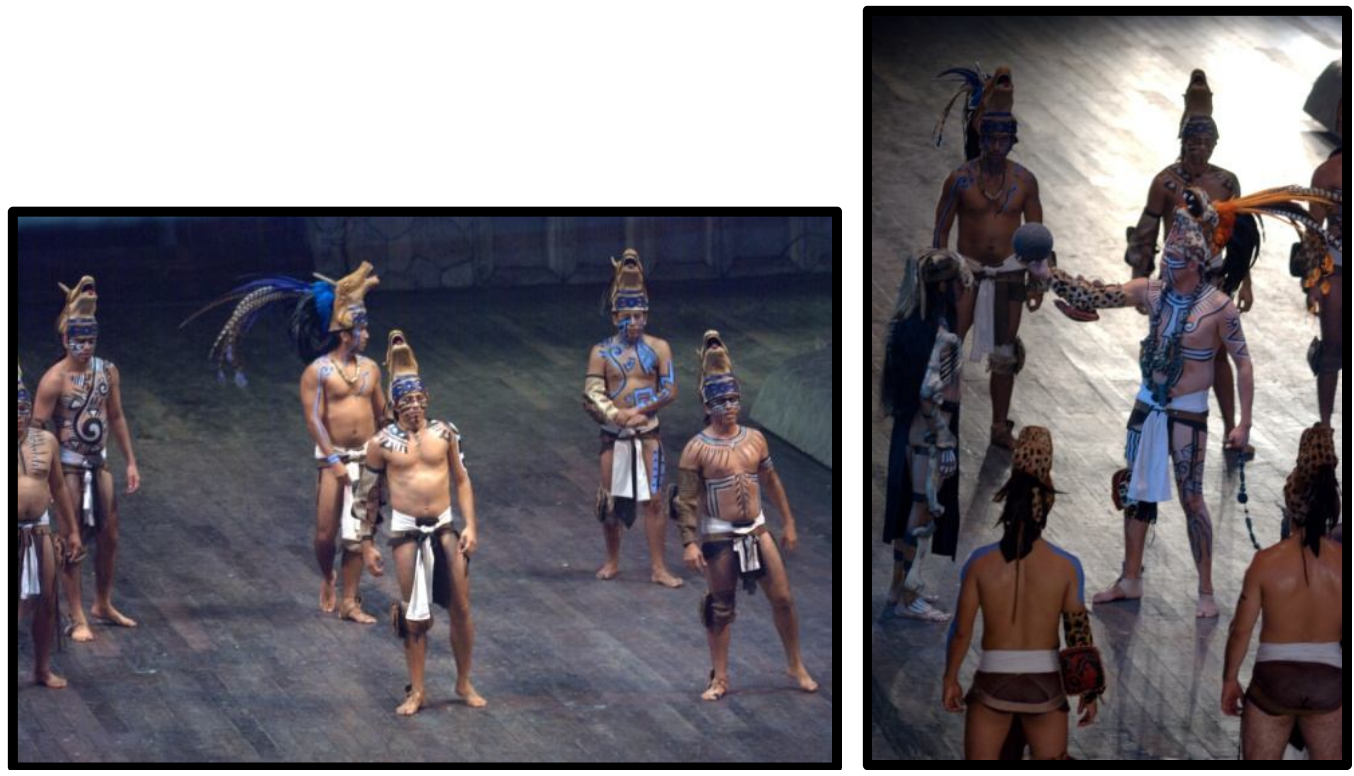

Ilustração II.11: Xcaret. México Espectacular. Cenas do início do jogo com a bola de borracha Pok ta' pok (Fotografias: Gustavo Accacio, 2009). 
Em Barcelona, na Espanha, o Museu d'Historia de la Ciutat também merece ser destacado. 0 núcleo Plaça del Rei é um ótimo exemplo de uma exposição arqueológica que se utiliza de meios interpretativos para a apresentação do local. Ao tomar o elevador para o subsolo arqueológico, o turista acompanha, no visor do elevador, uma contagem regressiva de tempo que automaticamente o transporta para outra época, à Barcelona romana, exatamente à "antigua Colonia Iulia Augusta Paterna Faventia Barcino, fundada por el emperador Augusto alrededor del año 10 a.C. ${ }^{\prime 56}$. Os vestígios locais vão do século I a.C. ao século VII d.C. Embora existam vitrines com exposição de acervo, elas são poucas e, sempre que existem, estão acompanhadas de informações pertinentes sobre o que está sendo mostrado. O forte da exposição são as maquetes, as reproduções em vídeo e as placas interpretativas. Nessas mídias, é possível compreender o uso do espaço, reconhecendo locais de uso cotidiano (para banho, para preparo do vinho, para lavagem de roupa etc) (Ilustração II.12).

56 Fonte: Guia del MUHBA. Plaça del Rei. Conjunto Monumental. Disponível em: http://www.bcn.cat/museuhistoriaciutat/docs/GUIACMPR5cas_WEB.pdf. Último acesso: jun./2012. 

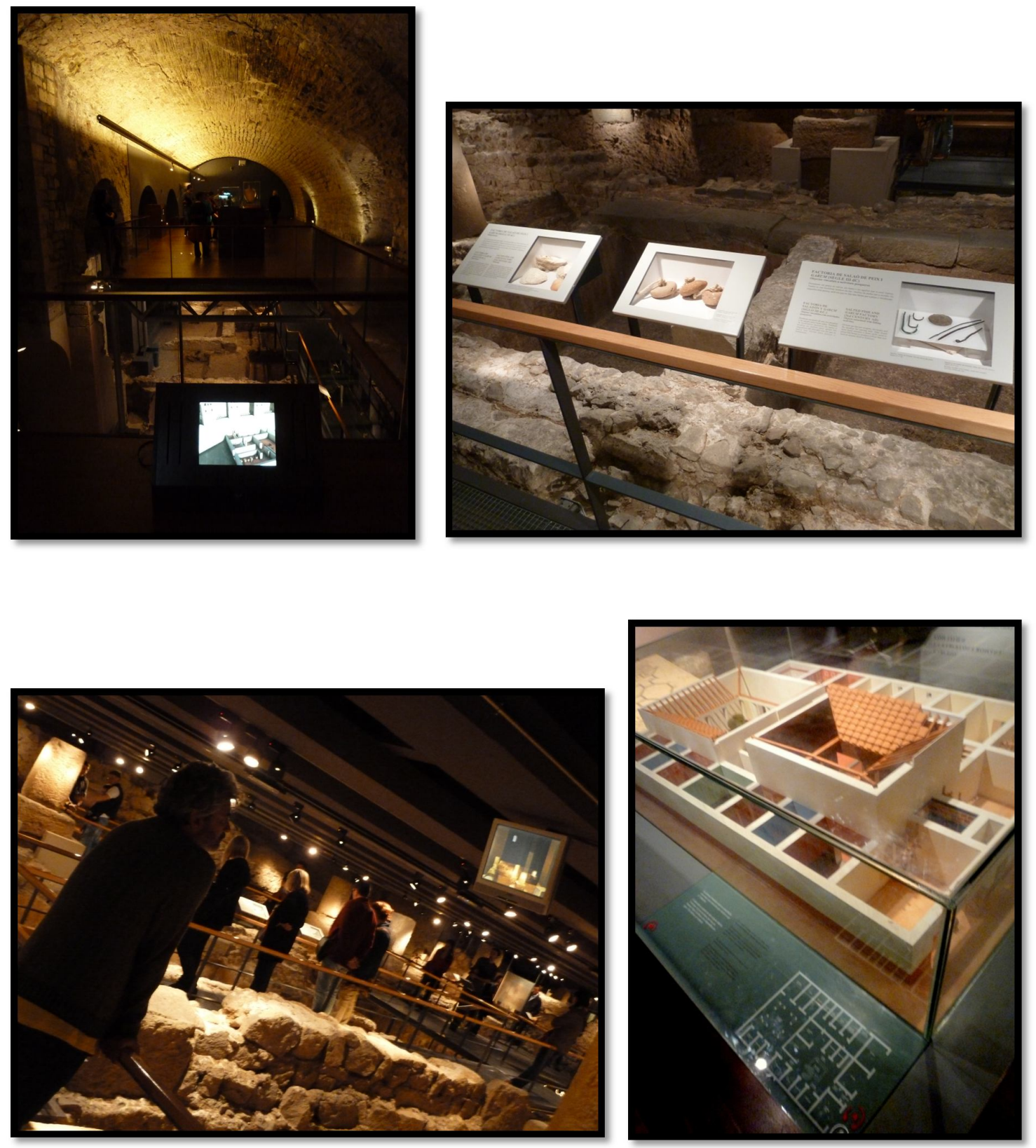

Ilustração II.12: Museu d'Historia de la Ciutat. Plaça del Rei. Barcelona, ES (FotografiAs: Adriana Guimarães, 2012). 


\section{II.4.2. Como e Por Que Elaborar um Planejamento Interpretativo Estratégico?}

Os exemplos acima mostram que a intenção de um programa interpretativo variará em função da realidade encontrada e, nesse sentido, é fundamental planejá-lo. O planejamento interpretativo deve ser um processo com começo, meio e fim. Muitos erros percebidos na elaboração da comunicação com o público referem-se à escolha das mídias a serem utilizadas antes de pensar sobre (CARTER, 2001: 06):

- Why you want to communicate with visitors;

- Who your visitors are;

- What your place is like, and what it has to offer;

- What else is happening around;

- What you want to say about your place;

- How, and where, you are going to say it ${ }^{57}$.

Quer-se comunicar com o público porque se está diante de um patrimônio, entendido como importante, seja para a comunidade local, seja para qualquer pessoa, mesmo que habitando uma região longe daquela. Nesse sentido, como cada local possui uma história própria, a interpretação não é algo que possa ser repetido para qualquer lugar, já que precisa considerar os desafios críticos para a gestão daquele recurso específico, além dos estudos mais atuais e relevantes disponíveis para aquela área (STOEP, 2003). A partir desse conhecimento, podem ser traçadas estratégias que visam satisfazer tanto as necessidades da gestão, quanto as do público.

A análise do perfil do público com o qual se lida é fundamental para que sejam traçadas estratégias apropriadas de gestão e comunicação. Segundo Stoep (2003), para esse conhecimento, devem ser realizados estudos periódicos, buscando informações sobre os motivos da visita, os interesses particulares, em que tipo de grupo as pessoas chegaram ao local, quais as informações prévias de que dispõem e, ainda, tentar entender o que gera comportamentos inadequados.

\footnotetext{
57 *Por que comunicar-se com os visitantes? *Quem são os seus visitantes? ${ }^{*}$ Como se caracteriza o seu local e o que ele tem a oferecer? ${ }^{*} \mathrm{O}$ que mais está acontecendo ao redor do local? *O que você gostaria de dizer a respeito do seu local? *Como e onde você irá fazê-lo? [Tradução: Luciana M. Guimarães].
} 
Entre os visitantes de um local, os interesses podem ser distintos, e o planejamento deve considerar, portanto, as necessidades do público atual e futuro, cuidando de eliminar ou diminuir possíveis barreiras para o acesso e entendimento do patrimônio visitado. Em manual elaborado para guiar quem pretende submeter projetos a financiamentos no Reino Unido, o Heritage Lottery Fund salienta a importância da previsão do uso da interpretação nos projetos (HLF, 2009:6-7):

In planning your project we expect you to consider the needs of all your current and future visitors and be aware of any potential barriers to their access and understanding.

- Intellectual barriers make the content of interpretation difficult to understand - for example text that is too long and uses technical language. Being aware of this barrier is also about giving information in a variety of formats so that if people don't or cannot read they can access the content in other ways.

- Sensory barriers make interpretation difficult to see, hear or otherwise sense - for example text that is too small to read.

- Physical barriers make interpretation difficult to access - for example a display that is too high for children and people in wheelchairs to use.

- Cultural barriers fail to reflect the cultural perspectives of different audiences - for example interpretation only in English at a site visited by many foreign tourists or closely linked to an immigrant community.

- Financial barriers exclude people on low incomes - for example a site with a parking charge, an entrance charge and a further charge for an audio tour.

- Organisational barriers exclude visitors because of the way the interpretation is provided-for example an events programme running only during midweek ${ }^{58}$.

A análise do que existe para ser interpretado nos locais de visitação também é importante.

Martín (s/d) observa, por exemplo, que:

En el caso de los yacimientos arqueológicos no se pueden escenificar los emergentes materiales para el visitante como objetivo primordial; deve realizarse um trabajo interdisciplinar $y$ complejo donde tengan prioridades también la conservación y la investigación y no uma mera

${ }^{58}$ Durante o planejamento de seu projeto, esperamos que você considere as necessidades de todos os seus visitantes, atuais ou futuros, e que esteja ciente da existência de quaisquer potenciais obstáculos ao acesso e à compreensão do local. * As barreiras intelectuais tornam o conteúdo da interpretação difícil de ser entendido, como por exemplo, no caso de um texto muito longo e que faz uso de linguagem técnica. Ter consciência da existência de tal barreira diz respeito, também, à viabilização de informações de várias maneiras e formatos para que as pessoas, caso não leiam ou não saibam ler, possam acessar o conteúdo de outros modos. ${ }^{*}$ As barreiras sensoriais tornam a interpretação difícil de ser vista, ouvida ou sentida de qualquer outra maneira, como por exemplo, um texto com letras muito pequenas para serem lidas. ${ }^{*}$ As barreiras físicas tornam a interpretação difícil de ser acessada - por exemplo, um painel que esteja muito alto para crianças ou pessoas em cadeiras de rodas visualizá-lo. * As barreiras culturais deixam de refletir as perspectivas culturais de um público diversificado, como por exemplo, no caso de uma interpretação oferecida somente em inglês em um local visitado principalmente por turistas estrangeiros ou diretamente ligado a uma comunidade imigrante. * As barreiras financeiras excluem pessoas de baixa renda, como por exemplo, no caso de um local onde o estacionamento e a entrada sejam pagos, além da cobrança de uma taxa extra para passeios com áudio. * As barreiras organizacionais excluem visitantes devido à forma como a interpretação é oferecida, como por exemplo, no caso de uma programação de eventos que sejam realizados somente durante a semana [Tradução: Luciana M. Guimarães]. 
realización de itinerários, señalizaciones más o menos atrayentes, insertar uma tienda, unos sanitarios y una cafetería. Porque:

- Los itinerarios (senderos o rutas) deben surgir da la comprensión del sitio, de su correcta excavación, de su documentación y de la consolidación y conservación de las estructuras arquitetónicas;

- La señalización no consiste sólo em la orientación física del visitante, sino em brindar uma información cientificamente válida, documentada, comprensible y amena (es dicir, interpretativa);

- Las construcciones anexas deben ser acordes com la demanda y no interferir com la comprensión global del yacimiento y su entorno;

- Los produtos de venta al público no son souvenirs, sino objetos de calidad testimonial y didáctica;

- Un yacimeinto o un inmueble no acaba em los limites de uma valla o las paredes de um edifício; debe tenerse em cuenta el entorno mediato e imediato, natural y cultural, objeto también de investigación y conservación.

Além disso, deve-se atentar para a ideia de conjunto e não de objetos e fatos isolados. Em planejamento, isso significa, conforme Martín (2000), que se fosse necessário definir uma escala de hierarquias semânticas em torno da vinculação do patrimônio com a sociedade, uma política de difusão patrimonial teria que ser estabelecida. Segundo esse autor, esta política estaria sujeita a dois aspectos: primeiro, ao reconhecimento e à subordinação a um modelo territorial e, segundo, ao reconhecimento e à potencialização de uma rede composta por museus, conjuntos históricos e arqueológicos, arquivos e bibliotecas. Esta rede, por sua vez, deveria estar relacionada à outra rede, formada pelos centros de acolhimento de visitantes e de interpretação, espaços expositivos, oficinas turísticas e pontos de informação cultural.

Esse modelo territorial e essas redes permitem, então, que se consiga apresentar uma área bastante extensa, evitando sobreposições e repetições de temas, que cansariam os visitantes, através da delimitação dos espaços a serem interpretados para atingir os objetivos desejados. Isto, em outras palavras, corresponde a um planejamento interpretativo estratégico. Para Carter (2001: 11), o planejamento interpretativo estratégico é o melhor meio para lidar com uma grande área ou um tema abrangente, pois (i) dá uma noção de perspectiva, (ii) pode estabelecer diretrizes para locais distintos ou assuntos específicos em planos mais detalhados, (iii) permite considerar as implicações do plano, além de (iv) orientar e coordenar os esforços de todos aqueles que querem desempenhar um papel, permitindo que várias organizações trabalhem em parceria, cada uma 
desenvolvendo a sua própria interpretação, (v) evitar a duplicação de esforços e (vi) incentivar redes apropriadas.

Ressalte-se, porém, que o planejamento interpretativo deve considerar, além disso, todo o processo de comunicação com os visitantes, da captação do visitante (materiais promocionais), a entrada (incluindo a viagem para o local), a chegada ao local (boas vindas e orientação), a visita, com as conexões que são geradas através das mídias e programas interpretativos no local (interpretação), ao final da visita (souvenirs, fidelização, eventos futuros etc.) e a saída (incluindo a viagem de regresso ou para outro destino) (NAl, 2009; FI, s/d) (Ilustração II.13).

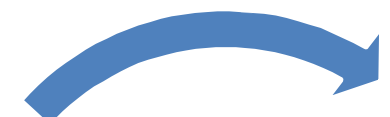

\section{Ao final da Visita}

Souvenirs, fidelização, eventos futuros etc.

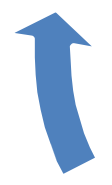

\section{Durante a Visita}

Interpretação

\section{A. Captação dos Visitantes (Antes da Viagem)}

Promoção

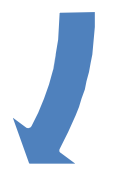

B. Na Chegada

Boas Vindas e Orientação

Ilustração II.13: Mecanismo de Comunicação com os Visitantes - Ciclo da Visitação (FonTE: traduzido e adaptado de Fl, s/d).

Os ensinamentos da Interpretação Patrimonial têm papel preponderante na condução desse trabalho. Todos os pontos aqui abordados, alinhados aos princípios estabelecidos anteriormente para um Turismo Arqueológico sustentável, foram considerados e serviram de base para pensar e definir as propostas apresentadas no último capítulo desta tese. 


\section{5. Propensão do Consumidor BRAsileiro para o TURISMO ARQUeOlóGICO.}

$\mathrm{Na}$ interface do turismo com a psicologia, existem diversos estudos relacionados às motivações dos turistas em relação às suas viagens e, nestas duas áreas, duas teorias são frequentemente citadas: a hierarquia de necessidades de Maslow e a classificação das necessidades humanas de Murray ${ }^{59}$. A primeira é a mais conhecida em turismo e propõe que as necessidades humanas formam uma hierarquia, sendo satisfeitas na respectiva sequência: necessidades fisiológicas, de proteção/segurança, sociais/de amor, de estima/respeito e de auto realização (Ross, 2001; SILVA, 2000). Nessa pirâmide motivacional, na medida em que uma necessidade é satisfeita, ela não é mais fonte motivadora de comportamentos. Além disso, em determinados momentos da vida, uma ou outra necessidade pode ser mais forte que outra (SILVA, 2000). Silva (2000: 73) esclarece ainda que "a motivação é conseqüência de algum tipo de necessidade que, satisfeita, promove o equilibrio do organismo", mas faz a ressalva de que nem sempre as pessoas reconhecem suas verdadeiras necessidades, ou têm o que ele chama "necessidades inconscientes".

A análise da motivação do turista possui diversas aplicações práticas para o turismo e a hotelaria. Entretanto, é interessante salientar que cada pessoa tem sua "pirâmide de necessidades" própria, possuindo, portanto, motivações distintas. Outros estudos preocupam-se em investigar as considerações que são feitas pelas pessoas na hora de escolher suas opções de destinos turísticos, desde as crenças iniciais que se tem do destino, até aquelas que passam pelas informações disponíveis, os valores e estilos de vida do próprio consumidor e as ligadas ao prestígio (Ross, 2001).

No turismo, é fundamental compreender esta complexidade tanto no planejamento da atividade e de produtos, quanto na composição e treinamento da equipe que lidará diretamente com o público. Deve-se considerar que a quantidade de informação difundida pela mídia sobre um determinado local e suas características próprias tem grande peso na

\footnotetext{
59 Para essa discussão, consultar livros de Psicologia do Turismo, como Ross, 2001 e SILVA, 2000, citados anteriormente.
} 
importância que lhe é conferida pelas pessoas e, portanto, no seu poder atrativo. No entanto, como bem lembram Mckercher e Du Cros (2002: 103-109 apud PÉREZ, 2009: 122):

O sucesso de um produto turístico-cultural vai depender da compreensão que o produtor tem das necessidades do consumidor. $\mathrm{O}$ que acontece é que muitas organizações turísticas ignoram as motivações reais da gente para comprar os seus produtos. Primeiro desenham produtos e só depois tentam procurar compradores, em vez de desenhar produtos para as necessidades do mercado.

O que, especificamente, pode motivar os turistas a visitarem atrativos culturais? Assim como há "escassez de pesquisas confiáveis e detalhadas" (SWARBROOK E HORNER, 2002: 85) sobre os fatores motivadores no turismo como um todo, há muito menos conhecimento sobre fatores motivadores de determinados segmentos de turismo. No Brasil, sabe-se tão pouco sobre tais fatores que o material governamental de referência sobre o Turismo Cultural (BRASIL, 2008: 21) cita um estudo mexicano, o qual aponta dois tipos de turistas que visitam os referidos atrativos em seus deslocamentos naquele país:

- Aqueles com interesse específico na cultura, isto é, que desejam aprofundar-se na compreensão das culturas visitadas e se deslocam especialmente para esse fim;

- Aqueles com interesse ocasional na cultura, possuindo outras motivações que o atraem ao destino, relacionando-se com a cultura apenas como uma opção de lazer. Esses turistas, muitas vezes, acabam visitando algum atrativo cultural, embora não tenham se deslocado com esse fim, e, apesar de não se configurarem como público principal do que conceituamos de Turismo Cultural, são também importantes para o destino, devendo ser considerados para fins de estruturação e promoção do produto turístico.

Infelizmente, o turismo brasileiro, especialmente o arqueológico, carece de pesquisas através das quais o comportamento do consumidor possa ser minimamente compreendido, de modo que seja possível planejar e colocar no mercado produtos eficientes. Como diz Cury (2006: 34):

Em síntese, não sabemos o que os brasileiros pensam sobre arqueologia. O que sabemos (ou temos como hipóteses) é que os brasileiros recebem informações superficiais e desconexas ou descontextualizadas; às vezes preconceituosas, importadas e, outras vezes, fantasiosas.

Por isso, mesmo consciente de que estudos sobre comportamento do consumidor podem ser muito longos e detalhados, e que este não era o foco deste trabalho, julgou-se que, para o cumprimento do seu objetivo (cf. pg. 02), precisava-se avaliar - algumas questões relacionadas ao interesse do público brasileiro pela arqueologia. 
Assim, realizou-se uma pesquisa complementar a esta tese, com as seguintes hipóteses: (a) os brasileiros interessam-se por arqueologia, (b) possuem informações sobre arqueologia brasileira e (c) há interesse em conhecer o patrimônio arqueológico brasileiro. $\mathrm{O}$ objetivo era entender como os brasileiros percebem o patrimônio arqueológico do país e o interesse destes em conhecer mais sobre o assunto, inclusive por meio do turismo.

O instrumento de pesquisa utilizado foi um questionário, já que questionários, em geral, têm como finalidade "obter, de maneira sistemática e ordenada, informações sobre as variáveis que intervêm em uma investigação, em relação a uma população ou amostra determinada" (DENKER, 2002: 146). Levando em consideração a atual opinião geral sobre o poder da internet em disseminar informações sobre a sua utilidade como ferramenta de complementação do ensino, avaliou-se que seria interessante testar o retorno que essa ferramenta poderia dar enquanto mecanismo para coleta de dados.

Em concordância com Neto (2004 apud MoYSÉS E MOORI, 2007):

Dentre as principais vantagens do uso da Internet na aplicação de questionários, é possível citar: (1) a conveniência: o respondente pode acessar o questionário de qualquer lugar, desde que tenha um microcomputador conectado à Internet; (2) o custo: o acesso virtual torna-se mais barato; (3) a escala: é possível de trabalhar com grandes amostras; (4) a velocidade: é possível obter as respostas mais rapidamente; e (4) a estética e a atratividade: é possível utilizar imagens, sons e hipertexto na construção dos questionários

Essa opção, contudo, não permite o controle da quantidade de questionários que será respondida online. Porém, isso não foi considerado um problema, já que, por ser esta uma pesquisa de abrangência nacional, quanto maior o número de questionários respondidos, mais significativa ela seria.

A pesquisa foi intitulada "Turismo e Arqueologia no Brasil". Foram formuladas 29 (vinte e nove) questões de formato variado, abertas, fechadas, semiabertas, encadeadas (DENKER, 2002), e diferentes escalas de interesses.

A primeira questão referia-se apenas à data de preenchimento, 07 (sete) questões (da 02 a 08) relacionavam-se à caracterização dos entrevistados, 14 (quatorze) questões, à arqueologia e as 07 (sete) últimas, à visitação de museus e sítios arqueológicos e ao interesse por viagens de arqueoturismo. Além de permitir correlações e cruzamentos sempre que necessário, as primeiras questões seguiam a indicação de que: 
Nas pesquisas sobre atividade turística se deve incluir no início as perguntas de cunho socioeconômico, como profissão, sexo, estado civil, idade (...), pois essas questões criam o ambiente de familiaridade entre entrevistador/entrevistado (TABARES, 1986 apud DENDER, 2002: 149).

O questionário foi construído através do site SurveyMonkey. Esse site permite a realização de diversos tipos de pesquisas. Cabe ao usuário decidir o formato de questão que será utilizado e como a pesquisa deverá ser respondida, por exemplo, se existirão questões de resposta obrigatória. Na medida em que os questionários são respondidos, o próprio site produz estatísticas simples para cada questão, além de gráficos que ilustram os resultados. O usuário também pode optar por visualizar cada questionário individualmente e, ao final, os resultados podem ser baixados em PDF ou em tabelas do Excel, permitindo que novas análises sejam efetuadas.

Inicialmente, a forma de divulgação do questionário foi por meio de uma lista de contatos de correio eletrônico. Num primeiro momento, o link para o questionário, juntamente com um texto de apresentação, foi enviado para cerca de 100 (cem) pessoas. Muitas destas pessoas, por sua vez, encaminharam o link do questionário às suas listas de contato (fato comprovado pelo recebimento de cópias desses envios). O link também foi divulgado para outros grupos de pessoas em um site de relacionamentos. Essas pessoas também ajudaram na divulgação do link em suas redes de contatos. Também por meio de um site de relacionamentos, fez-se um esforço de divulgação do link em comunidades cujas temáticas relacionavam-se ao turismo, ao ecoturismo e à cultura brasileira. Nelas, foram inseridos tópicos denominados Pesquisa sobre Turismo e Arqueologia no Brasil, através dos quais o link e um texto de apresentação foram divulgados. Os tópicos foram monitorados regularmente para que estivessem sempre no topo da lista, já que eles vão sendo passados para uma posição inferior da lista quando novos tópicos são acrescentados. Não é possível saber qual o efeito da divulgação por meio dessas comunidades. Em uma dessas comunidades, somente três pessoas manifestaram-se espontaneamente, afirmando terem acessado o link e respondido ao questionário.

Infelizmente, a expectativa em relação à grande quantidade de respostas que poderiam ser obtidas por meio da internet não se concretizou. Até o final de Janeiro de2010 apenas 184 (cento e oitenta e quatro) questionários haviam sido respondidos. Fez-se, então, um novo esforço de envio do link por e-mail e no site de relacionamento citado acima, estabelecendo 
um prazo final para o recebimento das respostas. Nesses últimos dias, o número de respostas aumentou para 219 (duzentas e dezenove), o que equivale ao total de respostas obtidas e analisadas.

Desta maneira, considera-se que houve um esforço significativo para divulgar o questionário, embora, dado a abrangência de transmissão de informação permitida pela internet, muito mais respostas fossem esperadas. De qualquer forma, acredita-se que a tentativa de divulgação do questionário por este meio tenha sido válida. Os resultados da pesquisa foram apresentados na II Semana de Arqueologia do MAE/USP, em 2011, e foram publicados na Revista do Museu de Arqueologia e Etnologia, onde é possível encontrar mais detalhes (GUIMARÃES, 2011: 201-206). Apresentar-se-á, a seguir, apenas um resumo dos resultados da mesma, com foco nas questões sobre Turismo Arqueológico.

O perfil socioeconômico do grupo que respondeu à pesquisa era, em sua maioria, de jovens, com idade entre 21 e 40 anos, de vários estados brasileiros e com nível educacional bastante elevado. As profissões eram bastante diversas e a renda média individual variada, mas com expressivo número de pessoas com poder aquisitivo elevado. Quase todos já tinham ouvido falar em arqueologia/pré-história e diversos meios de acesso a essas informações foram citados. Entretanto, as respostas indicaram que há necessidade de utilização da internet para a divulgação do assunto.

As respostas deixaram claro que, mesmo tendo acesso a informações sobre arqueologia em algum momento de suas vidas, a maioria das pessoas tem apenas uma noção, em muitos casos, vaga, do que ela seja propriamente. Isso ressalta, mais uma vez, a necessidade de criar mecanismos de aproximação com o patrimônio arqueológico, dando chances de as pessoas vincularem-se a ele.

Quando confrontadas com o patrimônio arqueológico em viagens ao exterior (a locais onde existia infraestrutura para a visitação, incluindo a interpretação desses espaços), os entrevistados puderam recordar-se com mais frequência dos nomes dos sítios visitados, lembraram-se dos povos que os construíram e relataram as experiências de visitação de forma mais apaixonada. No caso dos respondentes que tiveram contato com o patrimônio arqueológico brasileiro, as respostas sempre eram vagas e sem muitos detalhes. O que esta 
comparação sugere é que há um efeito positivo da criação de infraestrutura para visitação e do trabalho interpretativo realizado em muitos sítios no exterior.

Ao contrário do que sempre é dito, Indiana Jones e os locais monumentais, como oPeru, a Grécia ou o Egito, não foram a primeira lembrança de destinos arqueológicos para a maior parte das pessoas. Ao contrário, o trabalho dos arqueólogos, juntamente com suas escavações, foi bastante lembrado. Essas respostas desmistificam a ideia de que locais sem monumentalidade não são atraentes para o turismo.

Os comentários feitos pelos respondentes ao longo do questionário mostravam que eles sentiam falta de acessar informações sobre o patrimônio arqueológico brasileiro, como se estivessem sendo tolhidos da oportunidade de saber sobre o seu passado, sobre algo que eles consideram importante.

Muitas pessoas declararam ter tido contato com patrimônio arqueológico, no Brasil ou no exterior, citando os museus como o "instrumento" mais comum para tal experiência. Entretanto, um número significativo afirmou que teve contato com o patrimônio, no Brasil, em unidades de conservação (parques/reservas etc.), sugerindo que a visitação informal a sítios arqueológicos já está acontecendo. Este dado serve de advertência para o arqueoturismo brasileiro: o quanto antes um trabalho de planejamento e implantação de infraestrutura arqueoturística ocorrer, maior será a possibilidade de sustentabilidade desta atividade, bem como melhor será a qualidade das visitas turísticas.

Foi satisfatório perceber que as pessoas consideram o patrimônio arqueológico muito importante e que concordam com a necessidade de preservação dos sítios e dos materiais arqueológicos remanescentes para o usufruto das futuras gerações. Curiosamente, os entrevistados demonstraram saber as implicações das decisões de como esse material deve ser preservado, sendo que muitos demonstraram preocupação com sua retirada dos locais de origem.

Um dado muito relevante foi a disponibilidade que os entrevistados mostraram em ajudar a preservar esse patrimônio de alguma forma, embora achassem que o dinheiro com impostos já pagos deveria cobrir essa necessidade. Impressionou o fato de as pessoas declararem-se a favor do pagamento de valores altos para as entradas em museus e em sítios arqueológicos 
e, até mesmo, demonstrarem disponibilidade para realizar doações mensais a instituições (Gráfico II.1). Vê-se, portanto, que há bastante interesse do público em ajudar, de alguma forma, a conservação do patrimônio brasileiro, sugerindo também que a preservação in loco, com a possibilidade de realizar visitas, seria muito bem aceita pelo público, em diversas faixas de poder aquisitivo. Deste modo, este é mais um argumento a favor do Turismo Arqueológico.

GRÁFICO II.1:

Disponibilidade para pagar por 'entradas em museus', para 'visitar sítios arqueológicos' ou 'fazendo doação para instituições de proteção ao patrimônio'.

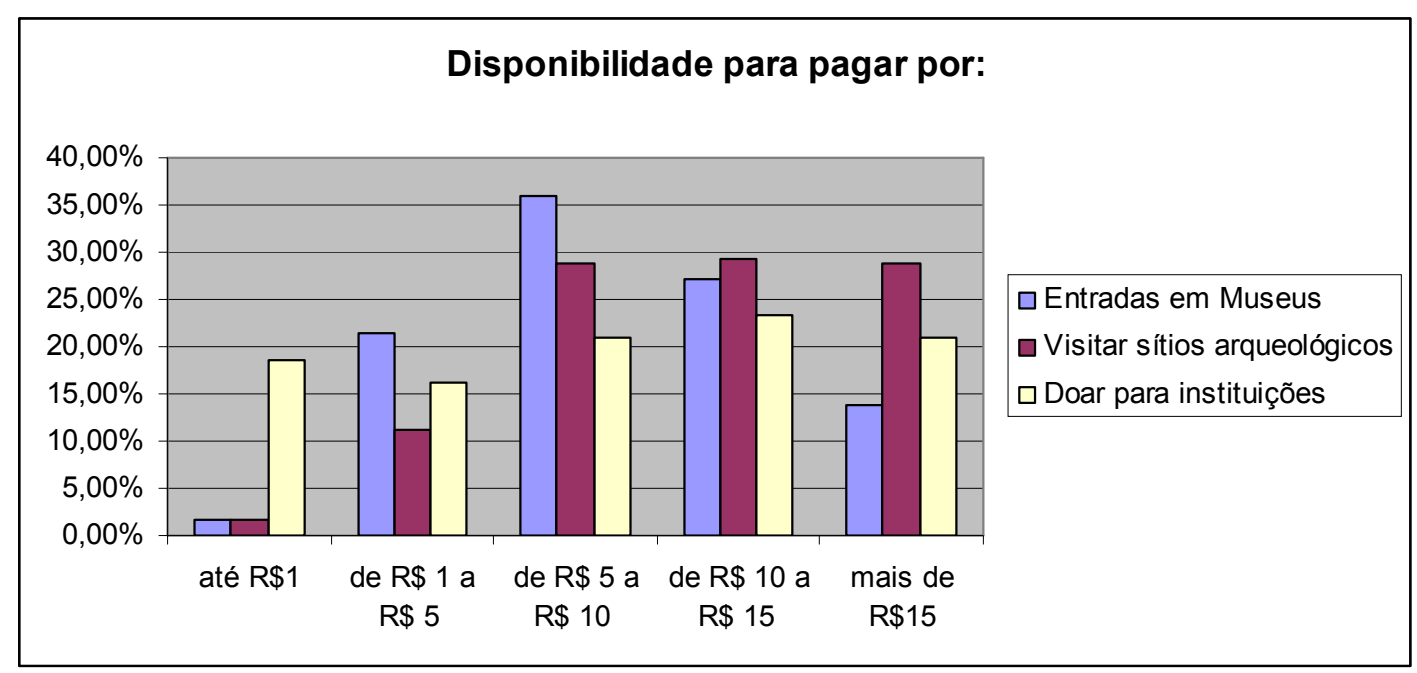

As perguntas relacionadas a possíveis viagens de cunho arqueológico indicaram que as pessoas têm muito interesse no segmento, ainda mais quando isso ocorre como complemento a outros tipos de viagens. A análise dos dados surpreende (i) em relação ao Brasil (Tabela II.6), porque, somando as que disseram 'algum interesse' com as que disseram 'muito interesse', quase todas as pessoas fariam uma viagem especificamente de Turismo Arqueológico, mesmo com a situação atual em termos de conhecimento do que há para ser visitado; (ii) em relação ao exterior (Tabela II.7), pois, o nível de interesse foi bastante equivalente ao demonstrado para o turismo nacional. No entanto, era esperado que o interesse "especificamente para conhecer/visitar o patrimônio arqueológico" pudesse ser maior neste caso devido à monumentalidade e à fama de tantos sítios estrangeiros. Nos dois casos, destaca-se que a inserção de produtos de Turismo Arqueológico em outros segmentos turísticos seria bem aceita pelo público brasileiro. 
TABELA II.6:

Nível de interesse em realizar viagens arqueoturísticas no Brasil.

\begin{tabular}{lccc}
\hline Brasil & $\begin{array}{c}\text { Nenhum } \\
\text { interesse }\end{array}$ & $\begin{array}{c}\text { Algum } \\
\text { interesse }\end{array}$ & $\begin{array}{c}\text { Muito } \\
\text { Interesse }\end{array}$ \\
\hline $\begin{array}{l}\text { Especificamente para conhecer/visitar } \\
\text { patrimônio arqueológico do local }\end{array}$ & $6 \%$ & $\mathbf{4 7 \%}$ & $\mathbf{4 7 \%}$ \\
\hline Como complemento de uma outra viagem & $0,5 \%$ & $\mathbf{2 9 \%}$ & $\mathbf{7 0 , 5 \%}$ \\
\hline
\end{tabular}

FONTE: GUIMARÃES, 2011.

TABELA II.7:

Nível de interesse em realizar viagens arqueoturísticas no exterior.

\begin{tabular}{lccc}
\hline \multicolumn{1}{c}{ Exterior } & $\begin{array}{c}\text { Nenhum } \\
\text { interesse }\end{array}$ & $\begin{array}{c}\text { Algum } \\
\text { interesse }\end{array}$ & $\begin{array}{c}\text { Muito } \\
\text { Interesse }\end{array}$ \\
\hline $\begin{array}{l}\text { Especificamente para conhecer/visitar } \\
\text { patrimônio arqueológico do local }\end{array}$ & $5 \%$ & $\mathbf{4 2 \%}$ & $\mathbf{5 3 \%}$ \\
\hline Como complemento de uma outra viagem & $1 \%$ & $\mathbf{2 5 \%}$ & $\mathbf{7 4 \%}$ \\
\hline
\end{tabular}

FONTE: GUIMARÃES, 2011.

O índice de aceitação dos respondentes tanto à visitação de ruínas antigas interpretadas quanto a visitação de sítios arqueológicos musealizados, demonstra que esses atrativos ajudariam a incrementar os produtos turísticos de diversas regiões brasileiras, com boa aceitação pelo público (Tabela II.8). 
TABELA II.8:

$\mathrm{O}$ que as pessoas gostariam de ver em viagens arqueoturísticas.

\begin{tabular}{lccc}
\hline & Nenhum & Algum & Muito \\
\hline Arqueólogos trabalhando & $6 \%$ & $\mathbf{5 1 \%}$ & $43 \%$ \\
Palestras & $22 \%$ & $\mathbf{5 6 \%}$ & $\mathbf{2 2 \%}$ \\
Ruínas antigas interpretadas & $0 \%$ & $15 \%$ & $\mathbf{8 5 \%}$ \\
Um sítio arqueológico musealizado & $3 \%$ & $23 \%$ & $\mathbf{7 4 \%}$ \\
Museu & $2 \%$ & $34 \%$ & $\mathbf{6 4 \%}$ \\
Exposição & $1 \%$ & $40 \%$ & $\mathbf{5 9 \%}$ \\
Folders/ cartazes que contassem a história do local & $6 \%$ & $\mathbf{4 9 \%}$ & $45 \%$ \\
Apresentações guiadas por pessoas da localidade & $2 \%$ & $34 \%$ & $\mathbf{6 4 \%}$ \\
Encenações/ teatro & $26 \%$ & $\mathbf{4 6 \%}$ & $\mathbf{2 8 \%}$ \\
Ir a restaurantes temáticos & $21 \%$ & $37 \%$ & $\mathbf{4 1 \%}$ \\
\hline
\end{tabular}

FONTE: GUIMARÃES, 2011.

Como apontado anteriormente, essa pesquisa foi realizada apenas para balizar o trabalho que estava sendo realizado. Ela não é, de fato, uma pesquisa de mercado ou um estudo detalhado sobre a demanda em relação ao Turismo Arqueológico. Porém, os dados obtidos apontaram que a organização dessa atividade seria bem aceita pelo mercado turístico nacional, fortalecendo as propostas apresentadas por essa tese. 


\section{Capítulo III - As Pesquisas Arqueológicas e o Potencial para o TuRismo Arqueológico na Região do Projeto Amazônia Central (PAC).}

"Nossas pesquisas têm garantido a criação de museus e a ampliação
e manutenção de seus acervos, mas isso, todavia, não é suficiente.
Quando o patrimônio arqueológico se restringir apenas a evidências
depositadas em reservas técnicas e exposições nos museus, o mais
importante terá se perdido, as evidências 'in situ' e seus contextos.
Então saberemos que tudo o que fizemos não foi suficiente".

Monticelli (2005: 340-1)

Este capítulo contextualiza a área de pesquisa desta tese. Porém, embora tenha se desenvolvido na área conhecida como Amazônia central brasileira, considerou-se que, para essa contextualização, seria importante apresentar a Amazônia brasileira a partir de uma conjuntura integrada, onde ambiente, sociedades e economia estão intrincados, para, em seguida, focar na arqueologia regional e local. O recorte temporal aqui seguido equivale ao período de desenvolvimento deste trabalho (2008-2012).

Muitas dúvidas surgiram em relação a que pontos deveriam ser abordados na apresentação da arqueologia regional e local. De certa forma, impôs-se o desafio de sintetizar e transmitir as informações disponíveis, tentando fugir de abordagens puramente técnicas e construir um cenário "vivo" que pudesse ser visualizado por não-arqueólogos. A intenção era elaborar um texto que servisse de base para as propostas que serão apresentadas no próximo capítulo.

Por fim, expõe-se o potencial percebido para o desenvolvimento do Turismo Arqueológico na região amazônica e, mais detalhadamente, no estado do Amazonas, tendo como estudo de caso o município de Iranduba. 
Muito conhecida por ser a maior floresta tropical do planeta, a Amazônia estende-se por nove países ${ }^{60}$, dentre os quais o Brasil, onde ocupa quase a metade do território. Apesar da sua riqueza biológica inestimável, ainda a ser estudada e compreendida em sua complexidade $^{61}$, o mundo assiste à exploração desse potencial de forma assustadora e vê a floresta ser constantemente ameaçada por diversos fatores, como por exemplo (CALDARELLI, s/d): (i) o adensamento geográfico, (ii) os assentamentos rurais, (iii) os sistemas de transportes terrestres (dentre os quais estradas, rodovias e ferrovias), (iv) os empreendimentos para a geração e transmissão de energia (como a hidroeletricidade, com impacto não apenas na implantação de usinas, mas também na implantação das linhas de transmissão necessárias), além da (v) exploração de combustíveis fósseis, com transporte via polidutos ou gasodutos, (vi) a exploração mineral (garimpos de ouro e, em menor grau, a exploração de outros minerais, bem como a mineração industrial - ferro, alumínio, manganês, cobre etc.), (vii) a exploração madeireira e (viii) a atividade agropecuária.

A realidade mostra que essa região não consegue lidar com a forma tradicional de desenvolvimento socioeconômico. A maior parte das iniciativas mostra-se imediatista e ineficiente. Todavia, apesar de estar cada vez mais claro que a floresta tem mais valor quando conservada, ainda se insiste em derrubá-la. Essa situação faz com que o mundo todo mantenha suas atenções nessa região e, nesse contexto, velhas discussões voltam, frequentemente, à tona e novos questionamentos são feitos a cada dia.

Como há cerca de 40 anos, na Conferência de Estocolmo, o Brasil parece ainda não ter entendido que desenvolvimento e proteção do meio ambiente não podem mais ser considerados realidades antagônicas, mas sim complementares. Na época, um cartaz anunciava "Bem-vindos à poluição, estamos abertos para ela. O Brasil é um país que não tem restrições. Temos várias cidades que receberiam de braços abertos a sua poluição, porque o que nós queremos são empregos, são dólares para o nosso desenvolvimento" (DIAS, 2001). Em 2006, o então presidente da república se declara a favor do "crescimento a qualquer

\footnotetext{
${ }^{60}$ Brasil, Venezuela, Colômbia, Peru, Bolívia, Equador, Suriname, Guiana e Guiana Francesa.

61 "No que diz respeito à biodiversidade, os números no Brasil também impressionam. O país conta com a maior riqueza de animais e vegetais do mundo: entre 10 a $20 \%$ de 1,5 milhão de espécies catalogadas. (...) Considerando o fato de que a maior parte da biodiversidade mundial ainda está por ser estudada, e que os países desenvolvidos estão muito à frente quanto a inventários biológicos, estima-se que as investigações no Brasil, em especial na Amazônia, elevarão significativamente a posição do país nessas estatísticas, baseadas nos números disponíveis atualmente" (CAPOBIANCO et. al., 2001).
} 
custo", afirmando que, entre outras questões, a legislação ambiental é entrave ao desenvolvimento ${ }^{62}$.

Em 2008, o tom do discurso teve que mudar. Com o aumento desenfreado dos números do desmatamento no país e uma grave crise político-ambiental que resultou na saída da ministra do Meio Ambiente, Marina Silva - que parecia inspirar confiança ao resto do mundo - o Brasil foi foco de matérias em jornais internacionais que questionavam a soberania do país sobre a Amazônia de forma bem clara e direta, como no jornal americano The New York Times "Whose Rain Forest Is This, Anyway?" (Alexei Barrionuevo, 18/05/08) ou no texto do inglês The Independent (Save the lungs of our planet, 15/05/08): "Uma coisa está clara. Essa parte do Brasil é muito importante para ser deixada com os brasileiros".

Em 2009 ${ }^{63}$, o Instituto Brasileiro do Meio Ambiente e dos Recursos Naturais Renováveis (IBAMA) iniciou a Operação Arco Verde - uma série de ações contra o desmatamento ilegal da floresta e alternativas para trabalhadores do setor madeireiro da Amazônia. Surgindo da parceria entre quatorze Ministérios e a Casa Civil, a operação surtiu algum efeito e, no final daquele ano, foram anunciadas porcentagens históricas em relação à queda do desmatamento na Amazônia brasileira ${ }^{64}$. Porém, a prática governamental continuou apresentando uma visão desenvolvimentista, desprezando as críticas e apelos de ambientalistas e da sociedade em geral, com a consequência de que os índices de desmatamento voltaram a subir.

Entre 2009 e 2010, a floresta foi foco de muitas discussões, quase sempre ligadas à realização de grandes obras, como as das usinas hidrelétricas do rio Madeira (Santo Antônio e Jirau), em Rondônia; a reconstrução de cerca de 400 quilômetros da rodovia BR-319, que atravessa uma zona muito preservada do Amazonas, mesmo com os protestos do então ministro do Meio Ambiente, Carlos Minc, que apontava que a obra causaria grandes

\footnotetext{
${ }^{62}$ Ver matéria "Índios, MP e ambientalistas são entraves para o País, diz Lula", publicada no OESP em 23/11/2006 ou nota de repúdio às declarações do presidente no site da ONG Vitae Civiles (www.vitaeciviles.org.br), no Boletim de Nov./Dez. 2006.

63 Ver matéria "IBAMA inicia operação contra desmatamento" no Portal Ecodebate (http://www.ecodebate.com.br/2009/03/16/ibama-inicia-operacao-contra-desmatamento-na-amazonia/) Acesso: out./2010.

${ }^{64}$ Ver matéria "Desmatamento na Amazônia cai 45\% entre 2008 e 2009", publicada no site do OESP em $12 / 11 / 2009$.
} 
impactos ambientais ${ }^{65}$; e a aprovação dos estudos de impacto ambiental para implantação da Usina de Belo Monte, no Pará, uma das mais polêmicas.

No final de 2010, a Ministra da Casa Civil, tida como a "mãe" do Programa de Aceleração do Crescimento do governo Lula, Dilma Roussef, foi eleita presidente do país, indicando continuidade nas ações governamentais. E assim foi, de tal forma, que 2011 ficou marcado por iniciativas populares contra a construção de Belo Monte e as mudanças no Código Florestal brasileiro.

Por outro lado, em outubro de 2011, o IMAZON anunciou que as taxas de desmatamento na Amazônia Legal, para o período de agosto a outubro, haviam sido menores que em 2010. Contudo, $49 \%$ da área não puderam ser monitorados devido à presença de muitas nuvens ${ }^{66}$, o que torna essas taxas pouco confiáveis. No final do mesmo ano, o governo anunciou que o desmatamento na Amazônia atingiu o menor nível desde 1988, baseado em dados do Instituto Nacional de Pesquisas Espaciais (INPE). No entanto, ainda não há tanto o que comemorar, já que a área desmatada ainda foi de 6,2 mil quilômetros quadrados entre 2010 e $2011^{67}$.

O ano de 2012 começa com a população brasileira preocupada com a construção de mais 16 (dezesseis) usinas hidrelétricas anunciadas para a região amazônica e com a publicação de artigos apontando as incertezas associadas aos reservatórios recém-implantados ou em processo de implantação no rio Madeira ${ }^{68}$.

Para a procuradora regional da república, Sandra Akemi Kishi (2011: 147):

\footnotetext{
65 Ver matéria "Dilma inaugura trecho da BR-319, alvo de polêmica entre Minc e Alfredo Nascimento", publicada em 24/03/2010 pelo site O Globo (http://oglobo.globo.com/pais/mat/2010/03/24/dilma-inauguratrecho-da-br-319-alvo-de-polemica-entre-minc-alfredo-nascimento-916156920.asp). Acesso: out./2010.

${ }^{66}$ Ver Hayashi, S., Souza Jr., C., Sales, M. \& Veríssimo, A. Boletim de Desmatamento (SAD) Outubro de 2011. Disponível em: http://www.imazon.org.br/publicacoes/transparencia-florestal/transparencia-florestalamazonia-legal/boletim-de-desmatamento-sad-outubro-de-2011. Acesso em: fev./2012.

${ }^{67}$ Ver matéria de divulgação "Desmatamento na Amazônia atinge a menor taxa desde 1988", publicada em 05/12/2011 em http://blog.planalto.gov.br/desmatamento-na-amazonia-atinge-a-menor-taxa-desde-1988/. Acesso em fev./2012.

${ }^{68}$ Ver artigo: "Peixes do Madeira desaparecem como os cientistas previram. Depois vem Belo Monte", de Leão Seva, publicada em 18/01/2012 no blog Observador Político (http://www.observadorpolitico.org.br/2012/01/peixes-do-madeira-desaparecem-como-os-cientistaspreviram-depois-vem-belo-monte/) Acesso em: fev./2012.
} 
[a] biodiversidade é fonte de subsistência humana e da natureza, é a própria vida. É ela que nos oferece alimentos, vestuário, medicinas, lazer e diversos serviços ecossistêmicos que sustentam o ciclo natural da Terra, portanto, o desenvolvimento natural e humano. É sustento direto de populações locais e de pessoas economicamente hipossuficientes, as quais serão as mais severamente afetadas com a intensiva perda e extinção da biodiversidade. Esta realidade reclama um novo olhar sobre a diversidade biológica, um olhar integrado e compromissado com a sustentabilidade das presentes e futuras gerações humanas e não humanas.

Concorda-se com essa opinião e acrescenta-se que é necessário conduzir esse "olhar integrado" também ao passado, já que na Amazônia brasileira não é somente o patrimônio biológico que está em risco. Ali, o homem não é um acontecimento tão recente quanto se possa imaginar. Um rico patrimônio arqueológico entrelaça-se ao ambiente natural (na terra, nas pedras e, até mesmo, em grandes extensões de florestas).

Como afirma Hornborg (2005), "[p]esquisas recentes em antropologia e arqueologia têm mostrado que por milhares de anos a região foi povoada por diferentes culturas e sociedades que deixaram suas marcas na paisagem". Na Amazônia, é comum, literalmente, andar sobre sítios arqueológicos. Muitas comunidades ribeirinhas, ou até mesmo grandes cidades da região, assentam-se em locais que já foram ocupados anteriormente e a cada trabalho arqueológico, mesmo em áreas atualmente inexploradas, descobrem-se mais áreas com vestígios de presença humana. Tal fato contraria a noção de "floresta virgem", propagada por muitos.

Nowadays, while more and more deforested and burnt areas of the rainforest lead to the displacement of the indigenous peoples, to the destruction of their culture and to the disappearance of countless animal and plant species, the questions about the future of this unique ecological system have to be raised again and again: After all, the largest imaginable "Monument of Nature" is not only a matter of natural heritage; it is also a matter of cultural heritage at risk (ICOMOS, 2010) ${ }^{69}$.

Atualmente, são conhecidas centenas de sítios arqueológicos na Amazônia, tanto nas Terras Firmes quanto nas Várzeas, da foz do rio Amazonas até além das atuais fronteiras brasileiras e, também, no rio Negro e seus tributários. Porém, apesar das muitas pesquisas já

\footnotetext{
${ }^{69}$ Hoje em dia, quando um número crescente de áreas desflorestadas e queimadas de floresta tropical causa o deslocamento de povos indígenas, a destruição de suas culturas e o desaparecimento de um número incontável de espécies animais e vegetais, as questões acerca do futuro deste sistema ecológico único devem ser novamente levantadas: afinal, o maior "Patrimônio Natural" imaginável não é apenas uma questão de patrimônio natural; é também a questão de um patrimônio cultural que se encontra em risco de desaparecimento [Tradução: Luciana M. Guimarães].
} 
desenvolvidas na região, a quantidade de estudos ainda é pequena diante da aparente grandiosidade desse patrimônio (Ilustração III.1).

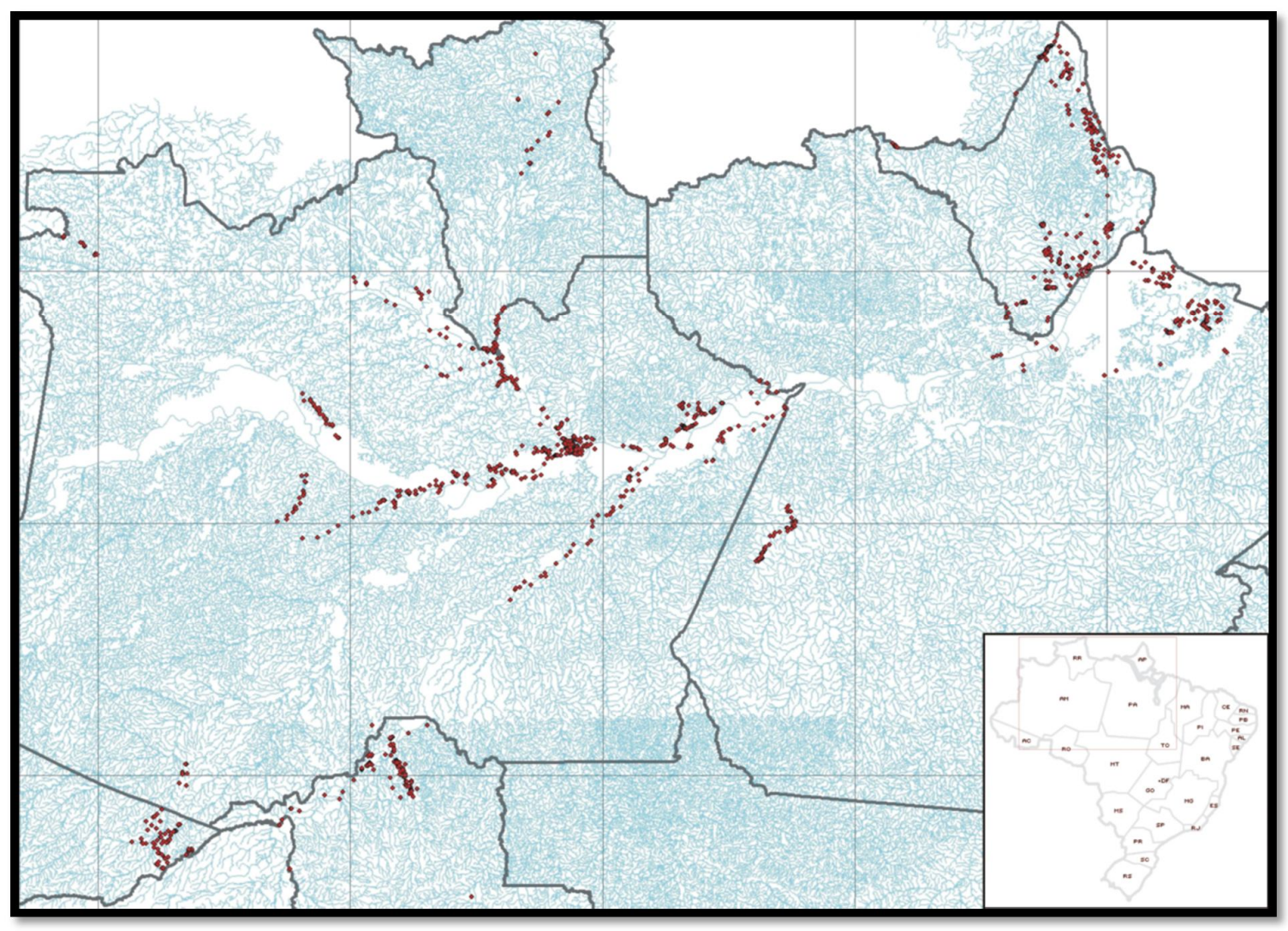

Ilustração III.1: Mapa com a localização de sítios arqueológicos na Amazônia brasileira. Sítios na Amazônia central e porção SO: dados compilados por Eduardo Tamanaha com base nos dados do PAC e em informações cedidas por pesquisadores ligados ao PAC; sítios na região do Tapajós, PA: informações cedidas pela pesquisadora Bruna Rocha; sítios no Amapá e NE do Pará: informações cedidas pelo arqueólogo João Saldanha (ARTE: Gustavo Accacio, 2012) ${ }^{70}$.

Pesquisas contínuas vêm ocorrendo nas últimas décadas, graças, principalmente, aos trabalhos da arqueologia de contrato/preventiva. Os Estudos de Impacto Ambiental (EIA), realizados para a implantação de grandes empreendimentos na Amazônia, estão identificando e resgatando muitos sítios arqueológicos. Porém, são frequentes as reações frente à liberação de áreas com aparente importância científica, mas ainda pouco pesquisadas, que são estudadas rapidamente, resgatadas e liberadas para destruição ou

\footnotetext{
${ }^{70}$ Esse mapa é ilustrativo da situação do conhecimento arqueológico na Amazônia brasileira. Porém, ressalvase que muitos sítios arqueológicos já conhecidos estão ausentes nesta listagem devido à imensa dificuldade em acessar informações sobre os mesmos.
} 
submersão. Conforme Monticelli (2005: 333), "[a] absoluta maioria das pesquisas são posteriores à ameaça dos impactos e não impedem que estes aconteçam, mesmo quando o patrimônio cultural existente é digno de importância e preservação". O resgate, por sua vez, nem sempre é a solução ideal, ainda mais quando acontece no ritmo que os contratos impõem.

Além disso, Caldarelli $(\mathrm{s} / \mathrm{d}$ ) avalia que dentre todos os fatores causadores de desmatamento e, consequentemente, de degradação dos bens arqueológicos, somente alguns precisam cumprir a legislação ambiental, sendo que nem sempre estes são os mais impactantes. Os assentamentos de reforma agrária realizados pelo INCRA, por exemplo, têm sido apontados como um dos principais fatores de desflorestamento (PERES E SCHNEIDER, 2011) e estão isentos desses estudos.

De fato, a diferenciação ecológica da floresta acomoda adaptações humanas distintas em seu interior ${ }^{71}$. A presença humana na região é tão importante, principalmente pelas diferentes formas de lidar com os ecossistemas locais e pelos conhecimentos tradicionais acumulados pelas populações locais, que mesmo em projetos de cunho conservacionistas o fator humano tem merecido atenção. Há cerca de dez anos, o projeto de Avaliação e Identificação de Ações Prioritárias para Conservação, Utilização Sustentável e Repartição dos Benefícios da Biodiversidade na Amazônia brasileira já direcionava uma seção à Sociodiversidade e Etnoconhecimento, com foco nas populações tradicionais e seus conhecimentos - Documentos Temáticos 2. Hoje, existem na região inúmeras organizações não-governamentais (ONGs) que trabalham em diversos eixos, mas quase sempre sob a égide da sustentabilidade e do envolvimento comunitário.

Também é fundamental considerar as relações entre as culturas amazônicas e o complexo ecossistema regional, quando se pretende produzir teorias sobre a ocupação humana na região (CALDARELLI, 1992). Encontrar alternativas para o desenvolvimento sustentável deve ser a meta a ser alcançada para a preservação do patrimônio ambiental e cultural brasileiro na Amazônia.

\footnotetext{
${ }^{71}$ Por exemplo, são conhecidos 375 povos indígenas na Amazônia. No Brasil, encontram-se, pelo menos, 170 povos, sendo que destes, 46 são grupos que ainda permanecem isolados. Além disso, cerca de 300 línguas estão em perigo de desaparecimento ou são vulneráveis (ARA, 2011).
} 
Apesar disso, o principal estigma ecológico ainda permanece: a visão homogênea de floresta tropical, uma mata densa, com árvores gigantescas e animais assustadores, um ambiente inóspito, quase intocado, onde o homem é mero ator coadjuvante. O bioma ${ }^{72}$ amazônico, no entanto, engloba diversos ecossistemas ${ }^{73}$ e inclui ainda algumas zonas de transição com os biomas vizinhos, como o cerrado e o pantanal. A composição da Floresta Amazônica é, assim, bastante variada.

Outro ponto que impressiona quando se fala em Amazônia é a quantidade de água que existe na região. A bacia Amazônica é a maior bacia hidrográfica do planeta. Entretanto, também os seus rios diferem entre si em suas características, sendo classificados em três categorias (AYRES, 1993):

- os de água branca (p.ex. o Solimões, o Madeira e o Jamari) que, por percorrerem terras ricas em minerais e suspensões orgânicas, são rios bastante produtivos. Transportam grande quantidade de sedimentos finos, como argila e siltes em solução e arrastam areia em seu leito. São nesses rios que se encontram as chamadas várzeas amazônicas, que são, na verdade, sedimentos depositados no solo pelas enchentes, adubando quilômetros de suas margens (Ilustração III.2);

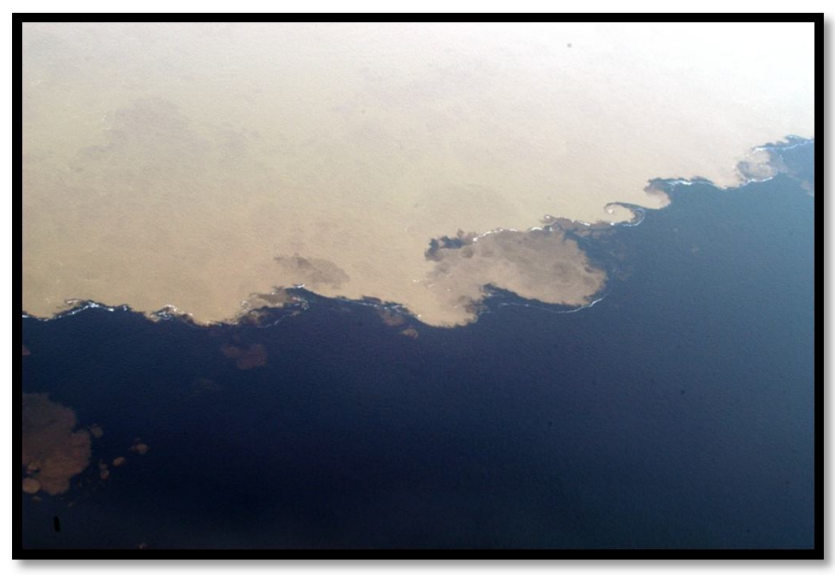

Ilustração III.2: Encontro das águas dos rios Solimões e Negro (Fotografia: Eduardo Neves).

\footnotetext{
72 "Biomes are basic categories of communities that differ in their physical environments and in the lifestyles of their dominant organism. (...) Biomes are a useful shorthand for describing certain kind of communities and, as such, help to facilitate communication among ecologists" (MORIN, 1999: 9). Os biomas são categorias básicas de comunidades que diferenciam-se em seus ambientes físicos e nos modos de vida do organismo dominante. (...) Os biomas são descrições abreviadas úteis de certos tipos de comunidades e, como tal, ajudam a facilitar a comunicação entre os ecólogos [Tradução: Luciana M. Guimarães].

${ }^{73}$ Quando se usa o termo ecossistema, está implícito que fatores bióticos (animais, plantas e bactérias) e abióticos (água, temperatura, ventos etc.) estão sendo observados.
} 
- os de água preta (p.ex. o Negro e o Uatumã), rios que percorreram áreas pobres em mineiras e são coloridos por substâncias húmicas, associadas aos solos podzólicos. Carregam pouca quantidade de sedimentos, com exceção da matéria orgânica em decomposição, proveniente da floresta, que geralmente se desenvolve até as suas margens. Podem transportar certa quantidade de areia em seus leitos, gerando bancos de areia em seus cursos. As águas são extremamente ácidas, classificadas como as mais pobres do mundo (Ilustração III.3);

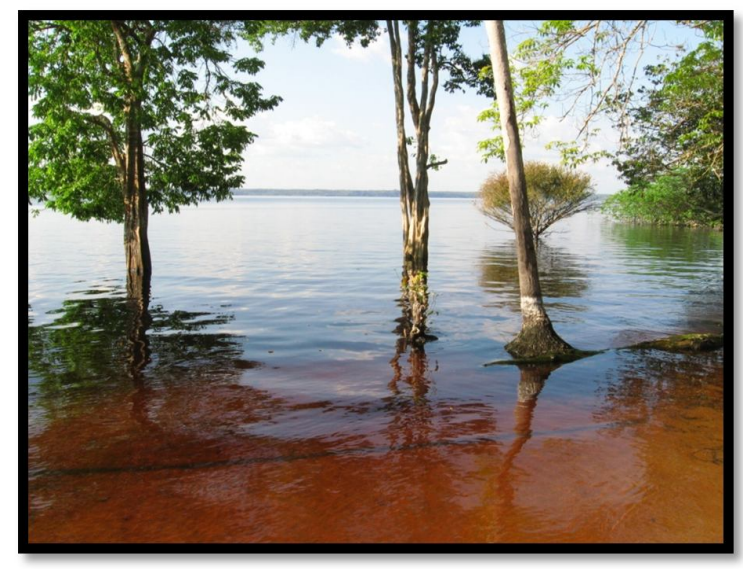

llustração III.3: Rio Negro (FotografiA: Adriana Guimarães, 2006).

- os de água clara (p.ex. o Tapajós e o Tocantins), também provenientes de formações antigas, possuem águas transparentes, esverdeadas, pobres em minerais e nutrientes e com caráter químico altamente variável (Ilustração III.4).

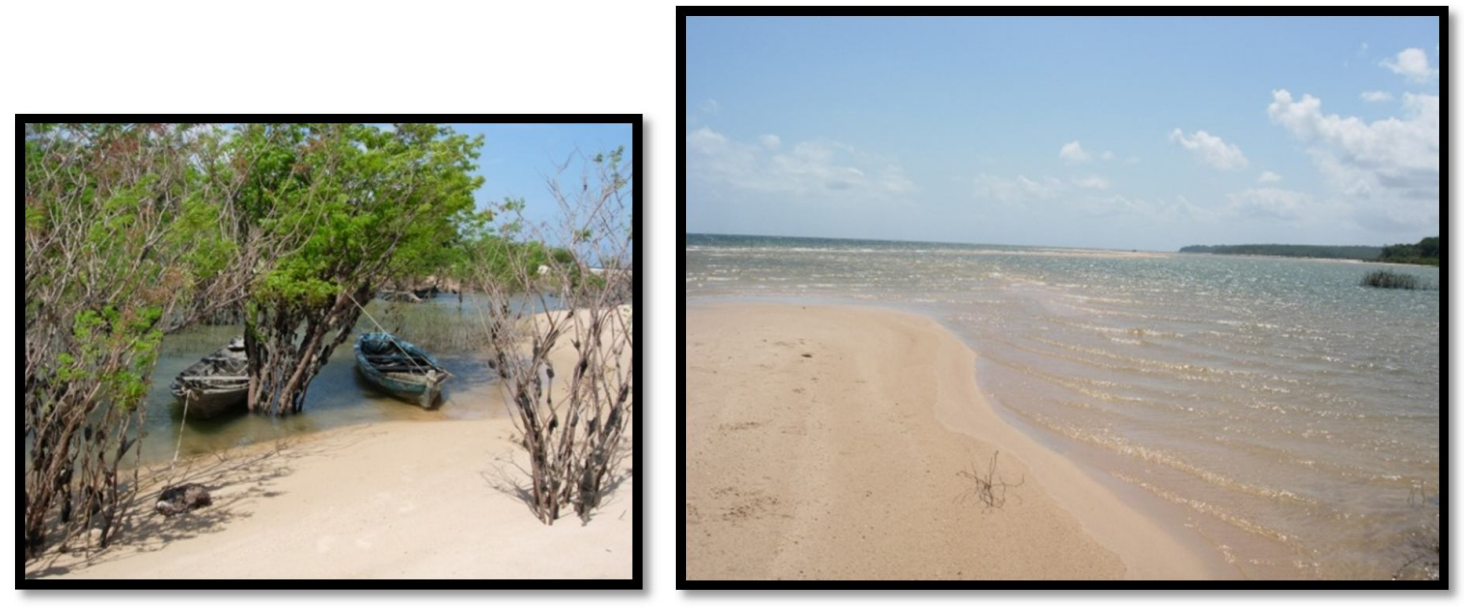

Ilustração III.4: Rio Tapajós (FotogRAFıAs: Adriana Guimarães, 2006). 
Há grande divergência teórica entre as principais correntes de pensamento que norteiam as pesquisas arqueológicas na região, sendo que a grande questão talvez seja se existiram grandes sociedades, complexas culturalmente, no ambiente de floresta tropical. Por um lado, o ambiente de floresta tropical, juntamente com alguns outros fatores ecológicos, como instabilidade climática, imporia uma limitação ao desenvolvimento cultural, como um "inferno verde" (MEGGERS, 1954), de tal modo que o desenvolvimento de grandes assentamentos e de sociedades complexas seria limitado (MEGGERS, 1995). Por outro lado, a região teria sido um centro de inovação cultural, hipótese postulada por Lathrap (1970), segundo a qual os rios e afluentes da bacia Amazônica teriam facilitado a dispersão das inovações culturais ali iniciadas.

Betty Meggers foi muito questionada pelo determinismo ecológico de sua teoria, e a arqueologia amazônica tem sido fortemente marcada pela tentativa dos pesquisadores em provar a existência de grandes sociedades, pautados na consideração da cultura como fator determinante para driblar as imposições ambientais e, também, na riqueza ecológica da floresta. Entretanto, o modelo cardíaco de Lathrap (1970), bem como as datas por ele propostas para o processo de inovação cultural ali iniciado, entre 6000 e 7000 AP (LATHRAP, 1977), não foram, até então, confirmadas (NEVES, 2002).

Para alguns autores influentes na área de arqueologia, como é o caso de Denevan (1992), as diferenciações de habitat não devem ser feitas, como ele próprio faz questão de explicitar, pelo tipo de rio e sim pelo tipo de solo e vegetação encontrada. Deve-se observar, não obstante, que a relação rios $x$ solo $x$ vegetação é indissociável num ambiente como o da floresta amazônica. Tomando como exemplo a bacia do rio Negro, percebe-se que são encontrados diversos tipos de vegetação e solo, entre eles as florestas de terra firme, as caatingas amazônicas - altas e baixas - e os campos abertos (OLIVEIRA et al., 2001).

O rio Negro é um dos três maiores rios do mundo. Em muitos locais, sua largura e profundidade são impressionantes. O nível de suas águas varia de 9 a 12 metros, a depender da época do ano, provocando inundação em grandes áreas de floresta, nas cheias, e o surgimento de praias, nas secas (ZEIDEMANN, 2001).

Vicentini (2001) afirma que, devido aos relatos dos "naturalistas europeus dos séculos precedentes", criou-se "uma Amazônia idealizada, coberta por árvores altas e grossas", 
apontando para o fato de que, ao conhecer a Amazônia mais de perto, o visitante pode se decepcionar, já que nem sempre a imagem vista por ele será essa. Para esse autor, a floresta de terra firme é o tipo de vegetação que melhor representa tal descrição da floresta amazônica. Ele explica que essa floresta (VICENTINI, 2001: 145):

[O]corre nas partes mais altas do relevo, em áreas não sujeitas a inundação durante as chuvas ou nas cheias periódicas dos rios. É ela que compõe o tapete verde sem fim das imagens aéreas da Amazônia. Entretanto, a terra firme, que parece homogênea na vista aérea, compreende vários tipos de vegetação, caracterizados por diferentes estruturas e conjuntos de espécies.

Em relação às florestas sobre areia, Oliveira et al. (2001: 184) apontam:

(...) na Bacia do Rio Negro há muitas diferenças entre as formações florestais sobre areia branca, designadas caatingas altas ou campinaranas, as formações mais arbustivas, designadas caatingas baixas e os campos abertos, denominados campinas. Essas definições são difíceis de ser aplicadas, pois fazem parte de uma transição contínua em que os limites não estão claros.

Em $O$ paradoxo de florestas em solos pobres, percebe-se que a complexidade ecológica dessas regiões é tão grande que é impossível fazer generalizações, mesmo quando se trata apenas de parte da imensa floresta Amazônica, como pode ser percebido no texto citado anteriormente e reproduzido abaixo (OLIVEIRA et al., 2001: 195-196):

Examinando as várias formações sobre areia branca na Amazônia, enfrentamos dois paradoxos. Primeiro, conciliar a presença de savanas e florestas raquíticas em pleno clima tropical úmido, onde predominam florestas densas e altas; e segundo, dadas as condições nas quais essas vegetações crescem, explicar como pode haver floresta e não deserto.

Entender a "pobreza" enganadora do Rio Negro não é difícil. Quase não há nutrientes nas areias lavadas e ácidas. A água disponível é ora excessiva, ora insuficiente: apesar da umidade alta e da chuva normalmente abundante e bem distribuída durante o ano, a areia não retém a água. Durante as chuvas, o solo alaga e, nos intervalos entre elas, as condições assemelham-se às de um deserto.

Para descobrir o motivo da existência de florestas em condições tão impróprias para o crescimento de árvores, precisa-se cavar um pouco. Por baixo de uma camada superficial e espessa de folhas caídas que demora para decompor nesse ambiente ácido, encontra-se uma trama densa de raízes que pode constituir até $60 \%$ da biomassa da vegetação, através da qual as plantas capturam e reciclam com muita eficiência os poucos nutrientes disponíveis. Alguns estudos mais recentes apontam para outro fenômeno, descoberto recentemente, que ajuda no desenvolvimento das florestas de campinarana. Em alguns locais, uma camada argilosa sob a areia funciona 
como um filtro, que retém material orgânico e nutrientes carregados da superfície pelas chuvas e que iriam se perder no lençol freático. Assim, a floresta mantém-se em solo pobre e ácido.

Meggers inspirou-se nas ideias de Julian Steward, antropólogo, fundador da chamada Ecologia Cultural. Steward trabalhou como arqueólogo durante muitos anos, embora não na América do Sul. Na direção do Instituto de Antropologia Social, do Smithsonian Institution, editou o Handbook of South American Indians (ERIKSEN E NIELSEN, 2007), cujos sete volumes são de fundamental importância para os estudos arqueológicos na América do Sul e influenciaram várias discussões ${ }^{74}$.

Steward considerava a totalidade de uma sociedade e seu entorno biológico mais ou menos do mesmo modo como um ecologista ${ }^{75}$ considera um ecossistema. Ele via a sociedade em grande parte com os olhos de um ecologista. Adaptação era um conceito essencial para Steward, que procurava instituições que promovessem concretamente a sobrevivência de uma cultura num dado ecossistema. Algumas dessas instituições eram fortemente determinadas pela tecnologia e pela densidade populacional; outras quase não eram afetadas pelas condições materiais (ERIKSEN E NIELSEN, 2007: 100).

Observa-se que a Ecologia Cultural de Steward, que teve influência direta do particularismo histórico de Boas, foi resultado do seu interesse pelo efeito do meio na cultura a partir do contato com a Geografia. O grande interesse da Ecologia Cultural volta-se às respostas adaptativas de culturas específicas a ambientes específicos, e a "prioridade da agenda stewardiana é demonstrar que o meio ambiente pode funcionar como fator gerador no processo de mudança cultural" (NEVES, W., 1996: 31). Walter Neves (1996) explica que o método da Ecologia Cultural propõe estudar a relação entre certas características do meio e determinados traços da cultura da sociedade humana que vive naquele meio. Para isso, causa e efeito entre ambiente e cultura são prioridades para Steward, mas nem cultura, nem ambiente, devem ser abordados como totalidade e, sim, somente alguns aspectos mais responsivos (que respondem) ou os mais influenciáveis.

\footnotetext{
${ }^{74}$ No Handbook of South American Indians, Steward classificou quatro tipos culturais distintos de ocorrência sul-americana: tipo Andino, tipo Circun-caribe, tipo de Floresta tropical e tipo Marginal.

75 Entende-se, neste texto, que o termo ecologista está aplicado no sentido de ecólogo, ou seja, o profissional que estuda os processos e interações ecológicas. No Brasil, o termo ecologista é mais comumente aplicado como sinônimo de ambientalista, que, não necessariamente, possui embasamento científico. A obra foi consultada em sua versão traduzida para o português, e considera-se que o uso do termo ecologista pode ter sido um equívoco na tradução.
} 
Carlos Fausto acredita que o ponto-chave nas pesquisas de Steward e dos seus seguidores foi colocar perguntas "erradas" produzindo, assim, respostas frágeis. Segundo esse autor, as populações das terras baixas teriam sido definidas pela sua negativa e os problemas a serem enfrentados pela arqueologia ficaram reduzidos a duas perguntas básicas: "será que todos os povos das terras baixas, de fato, não tinham aquilo que os incas tinham? E por que não tinham?" (FAUSTO, 2000: 15).

Lathrap (1970) formulou a principal objeção ao modelo de Meggers, defendendo a ideia de que a região de várzea teria produtividade suficiente para sustentar grandes assentamentos, devido aos sedimentos carregados pelo rio a partir dos Andes. Segundo ele, devido à reduzida presença destes sedimentos no total dos terrenos habitáveis, as populações teriam se dispersado em busca de novas áreas, usando, para isso, os rios. Porém, esse raciocínio é válido somente para os chamados rios de água branca, onde se encontram os terrenos de várzea amazônica, sendo que ele mesmo ressaltava as diferenças entre eles (LATHRAP, 1962: 551-552):

The longest archeological sequences and the largest sites in Amazonia are within the floodplain and wet savannas; shorter sequences and smaler sites occur along the smaller headwater streams; and the few known nonriverine sites are very small and indicative of small groups of nomadic or seminomadic people ${ }^{76}$.

Denevan (1992) acreditava na existência de grandes sociedades na Amazônia e estimou um grande contingente populacional para a 'grande' Amazônia' ${ }^{77}$, no período pré-colonial, de cerca de 6.800 .000 pessoas. Suas análises baseiam-se em dados pré-históricos, históricos e em evidências contemporâneas, em combinação com taxas de decréscimo populacional, em sua opinião, conservadoras. As estimativas de densidade populacional também foram feitas considerando distintamente os habitats observados. Esse autor afirma que (DENEVAN, 1992: 207):

[t]he distribution of aboriginal population in Amazonia was very uneven and was for the most part very sparse. This distribution, given the prevailing subsistence patterns,

\footnotetext{
${ }^{76}$ As sequências arqueológicas mais longas e os maiores sítios arqueológicos na Amazônia encontram-se em regiões de várzea e savanas inundadas; sequências arqueológicas de menores dimensões e sítios menores ocorrem ao longo de cabeceiras de rios menores; os poucos casos conhecidos de sítios arqueológicos não ribeirinhos apontam que estes são muito pequenos, indicando a presença de pequenos grupos de povos nômades ou seminômades [Tradução: Luciana M. Guimarães].

77 "Greater Amazonia thus incorporates all the tropical lowlands and plateaus of interior South America, an area substantially larger than the Amazon Basin proper" (DENEVAN, 1992).
} 
including technology, crops, and domesticated animals, was closely related to the nature of the natural habitat ${ }^{78}$.

E, ainda, que (DENEVAN, 1992: 209):

[W] here good soils and rich wildlife resources coincide, there can be expected the densest and most permanent native settlement, along the Amazon and its tributaries; where both soils and fish-game resources are poor, sparse and unstable human populations can be expected, as in the lowland interfluvial forests and in the upland savannas in the Guiana Highlands and the Brasilian Highlands ${ }^{79}$.

Apesar de constantemente apontarem a capacidade humana de superar as dificuldades encontradas nos locais onde habitam, Lathrap e Denevan sempre consideram a disponibilidade de caça e pesca, a fertilidade do solo e a facilidade de movimentação como fatores decisivos na densidade populacional de determinada área. Todavia, o próprio Denevan (1992) afirma que, sabendo que o potencial agrícola dos terrenos pode ser melhorado de maneira positiva, as populações utilizaram-se de diversas técnicas nesse sentido. Entretanto, ele aponta a falta de domesticação animal e de plantas com alto poder protéico como fator preponderante para o zoneamento ecológico das áreas amazônicas.

Mesmo com toda essa discussão, durante algum tempo, muitos trabalhos limitaram-se simplesmente a definir fases e tradições cerâmicas (DIAS, 2005). A atenção excessiva às cerâmicas se explica. Como se percebe com a observação de grupos indígenas atuais, grande parte da cultura material indígena é fabricada em fibras ou madeira, ou seja, materiais bastante perenes. Devido ao clima bastante úmido, ao alto índice pluviométrico e aos solos ácidos, a preservação desses materiais é muito baixa na Amazônia, limitando-se, quase sempre, aos materiais inorgânicos. Assim, cerâmicas e líticos são os vestígios arqueológicos mais comuns nessa região, embora não tenham sido os únicos materiais trabalhados pelas populações antigas. Não obstante, os vestígios cerâmicos oferecem ao arqueólogo uma gama de informações. A análise de partes estruturais de uma vasilha cerâmica (bordas, base,

\footnotetext{
${ }^{78}$ (...) a distribuição da população aborígene na Amazônia era muito irregular e, em sua maior parte, muito dispersa. Esta distribuição, considerando-se os modos de subsistência predominantes, que incluía tecnologias, colheitas e a domesticação de animais, relacionava-se, estreitamente, à natureza do habitat natural [Tradução: Luciana M. Guimarães].

79 Onde há coincidência de bons solos e de uma rica vida selvagem, podem ser esperados assentamentos nativos mais densos e permanentes, ao longo do rio Amazonas e de seus tributários; nos locais onde tanto o solo quanto os recursos pesqueiros são pobres, raros e instáveis, pode-se esperar a presença de populações humanas, como nas florestas interfluviais das terras baixas e nas savanas de terras altas no Planalto da Guiana e no Planalto Brasileiro [Tradução: Luciana M. Guimarães].
} 
paredes decoradas ou sem decoração, apliques, alças, flanges, entre outras) e o próprio estilo decorativo são as principais fontes de informações visíveis para o pesquisador em análises superficiais. Em alguns locais da Amazônia, a cerâmica apresenta-se tão ricamente decorada, seja através da pintura ou de decoração plástica, que muitas discussões teóricas a priorizam. A cerâmica amazônica apresenta decoração variada, dependendo da região onde é encontrada ou, no mesmo sítio arqueológico, quando esse foi ocupado sucessivamente. Como os mesmos padrões decorativos são percebidos em locais diversos, os pesquisadores do Programa Nacional de Pesquisas Arqueológicas (PRONAPA) criaram um sistema de sequenciamento seriado, onde complexos cerâmicos distintos eram agrupados em Fases. Diversas fases arqueológicas, com distribuição espacial ampla e persistência temporal, podem ser agrupadas em Tradições. Assim, desde 1961, quando as quatro principais tradições cerâmicas amazônicas foram definidas, elas passaram a servir de base para as análises regionais. São elas: a tradição Hachurada-Zonada, a Borda Incisa, a Policrômica e a Incisa e Ponteada. Essa classificação apenas indica a decoração mais popular, não significando que seja a única técnica empregada. Do mesmo modo, algumas dessas características podem ser comuns a outras tradições, como é, por exemplo, o caso da policromia (MEgGERS E EVANS, 1961).

Esses conceitos, que ainda são muito utilizados na arqueologia Amazônica, dizem respeito apenas a traços diagnósticos e características morfológicas e decorativas do material. Fabíola Silva (2009: 34) analisa que:

[e]m parte, a arqueologia amazônica ainda é exploratória. Nesse sentido, para alguns, a finalidade do trabalho arqueológico não é estabelecer a continuidade entre contextos arqueológicos e culturais, e sim revelar a extensão geográfica, cronologia e tipologia das tradições e fases arqueológicas. Em outras palavras, posicionar no espaço, descrever, datar e classificar os registros do passado (Noelli, 2008). É importante salientar que realizar uma pesquisa exploratória não é incorreto, ao contrário, é uma necessidade científica. A região amazônica ainda necessita de arqueologia exploratória, mas, ao mesmo tempo, já apresenta um conjunto de dados que possibilitam rever e refinar velhos paradigmas. Além disso, a atuação mais intensa das populações amazônicas em busca da autodeterminação e da construção da sua própria história obriga o pesquisador a rever a interpretação do registro arqueológico, no sentido de refinar as relações entre os contextos do passado e do presente. 
Enquanto essa revisão não acontece, é válido observar que, conforme Schaan (2006), o termo fase não deve ser usado como sinônimo para etnia ou tribo, nem para denominar peças em acervos ou exposições, como tem sido muito comum.

Atualmente, contudo, a construção do conhecimento arqueológico vem sendo cada vez mais interdisciplinar e muita informação está sendo obtida nos restos faunísticos, botânicos, sepultamentos humanos, sejam eles vestígios macro ou microscópicos. Assim, manter a integridade dos sítios arqueológicos é cada vez mais salutar. Estas novas análises têm sido importantes na complementação de dados, ajudando na revisão de teorias ou, até mesmo, influenciando a proposição de novas hipóteses.

Além de artefatos cerâmicos e líticos, os restos faunísticos, botânicos, sepultamentos humanos e uma infinidade de vestígios macro e microscópicos encontrados na região são passíveis de utilização como fonte potencial de informação histórica e cultural. A associação entre diferentes categorias de vestígios arqueológicos é, portanto, o meio mais efetivo de reconstrução dos modos de vida das sociedades pretéritas (LIMA, 2008:01).

Os sítios e vestígios estudados na região forneceram informações sobre a antiguidade da ocupação da área. As atividades humanas deixaram 'pegadas' ou assinaturas físicas no ambiente que apontam para uma interação homem e ambiente de mais de 11.000 anos na Amazônia (ERICKSON, 2008). As escavações têm mostrado uma enorme diversidade de sítios arqueológicos, dentre os quais são conhecidos:

(i) Sítios pré-cerâmicos (Ilustração III.5). Onde são encontrados materiais líticos que podem apresentar as datações mais antigas daregião. Na Amazônia central, esses sítios ocorrem em areais que estão associados à campinaranas, igarapés de água preta e afloramento arenito-silicificado e jamais ocorrem associados às Terras Pretas (COSTA, 2009). Registros de sociedades pré-cerâmicas também são encontrados em abrigos rochosos e cavernas. Costa (2009) descreve a rapidez com que os sítios em areais estão sendo destruídos na Amazônia central brasileira, situação que pode resultar em uma lacuna de conhecimento irreparável para o cenário arqueológico regional, já que sobre esse período ainda pouco se sabe. 

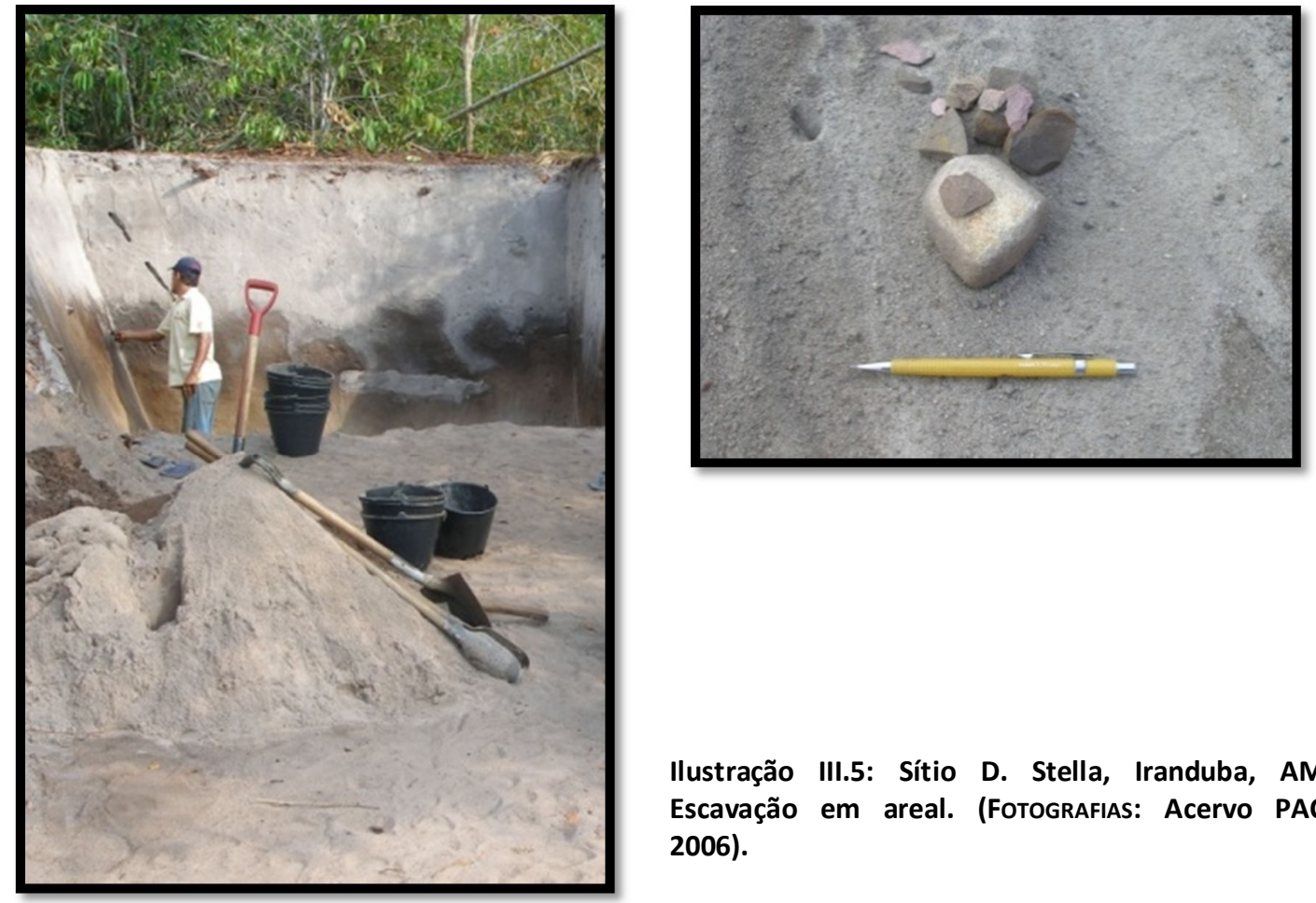

Ilustração III.5: Sítio D. Stella, Iranduba, AM. Escavação em areal. (Fotografias: Acervo PAC. 2006).

(ii) Sítios de Terra Preta (Ilustração III.6). Muito já se discutiu sobre a origem natural ou antrópica da Terra Preta, mas, atualmente, entre os arqueólogos, é praticamente unânime a crença de que ela é fruto da ação humana. Sob esse entendimento, esses solos são o resultado de uma deposição contínua de lixo, cinzas, fezes, urina, ossos, conchas etc., que necessita de bastante tempo para processamento. Isso implica, portanto, considerar que essa formação só seria possível se grupos humanos relativamente grandes ocupassem, por um longo período de tempo, o mesmo local (NeVEs et al., 2003; HORNBORG, 2005). No entanto, ainda se discute sobre a intencionalidade ou não da sua produção (NEVES et al., 2003) e sobre os processos que permitiram a formação desses solos escuros e o que os mantém férteis por longos períodos de tempo (SCHMIDT E HECKENBERGER, 2009). 

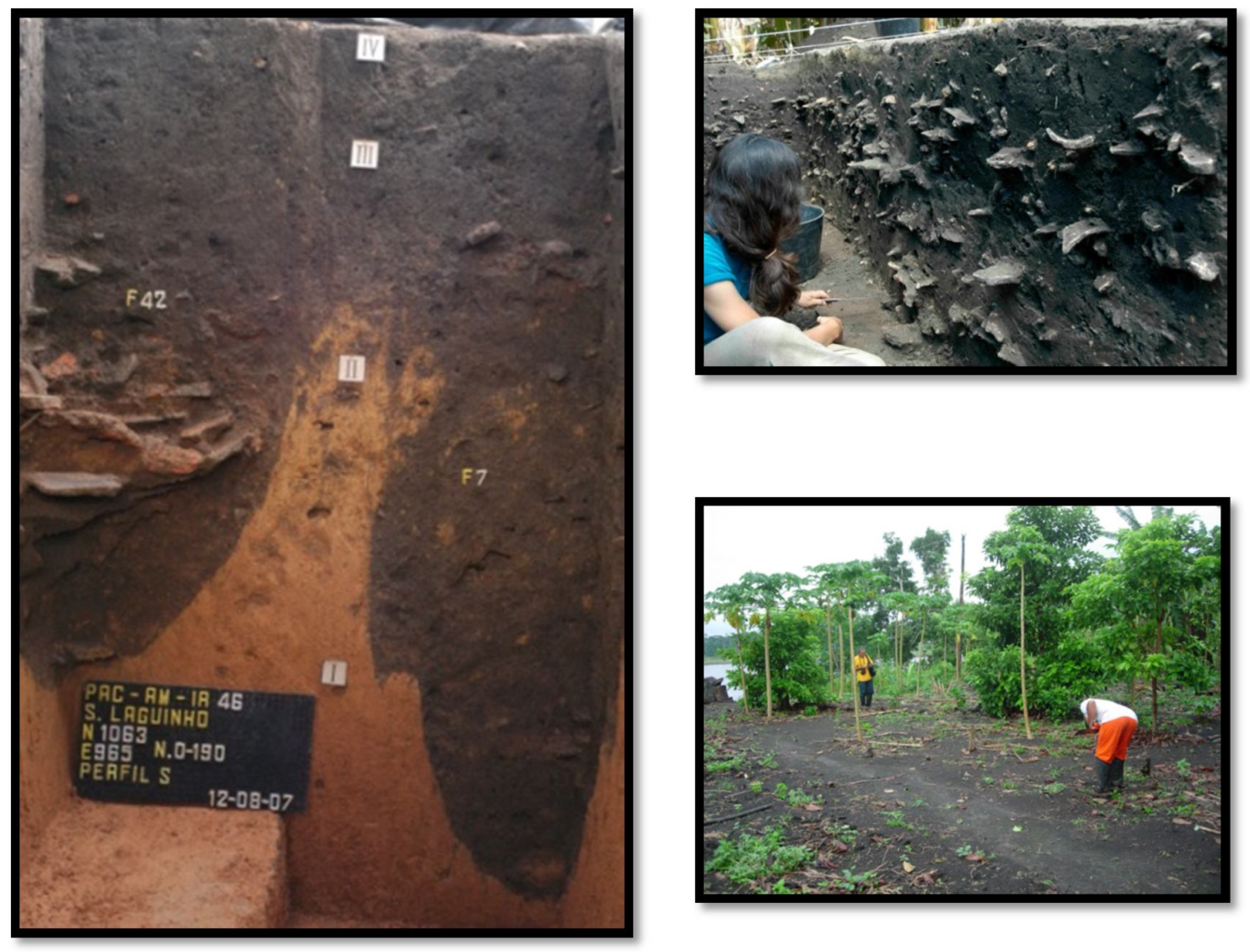

Ilustração III.6: Terra Preta. Escavações no Sítio Laguinho (à esquerda) (Fotografia: Acervo PAC) e escavação no Sítio Hatahara (acima à direita) em Iranduba, AM. (FotogrAFIA: Acervo PAC) e sítio de Terra Preta em Itacoatiara (FotografiA: Adriana Guimarães).

(iii) Sítios com 'montículos' (Ilustração III.7), que são estruturas de terra que podem ser encontrados sem sepultamentos (DONATTI, 2003) ou com sepultamentos (MACHADO, 2005). Claide Moraes (2006) defende que esses montículos podem ter sido construídos e estejam associados a unidades habitacionais, que se localizariam sobre os mesmos. Assim, seus posicionamentos na paisagem informariam acerca do formato das aldeias (MORAES, 2006). O pesquisador Morgan Schmidt (2012) está estudando montículos lineares ou anelares em diversos locais da Amazônia, inclusive na Amazônia central. Para ele, supostamente, muitos montículos podem ser associados a contextos domésticos, sendo o resultado de lixeiras localizadas nos fundos das casas e/ou bordas de caminhos, onde costuma ser depositado o lixo que se quer mais distante das residências. No entanto, Schmidt avalia que não existe uma regra única e é inviável supor que todos os montículos foram formados da mesma maneira e 
com a mesma finalidade. $O$ pesquisador conclui que o avanço no entendimento da estrutura interna dos assentamentos pré-históricos ajudará a responder questões importantes sobre o tamanho da população, o uso do espaço, e a formação dos solos antrópicos conhecidos como Terra Preta;
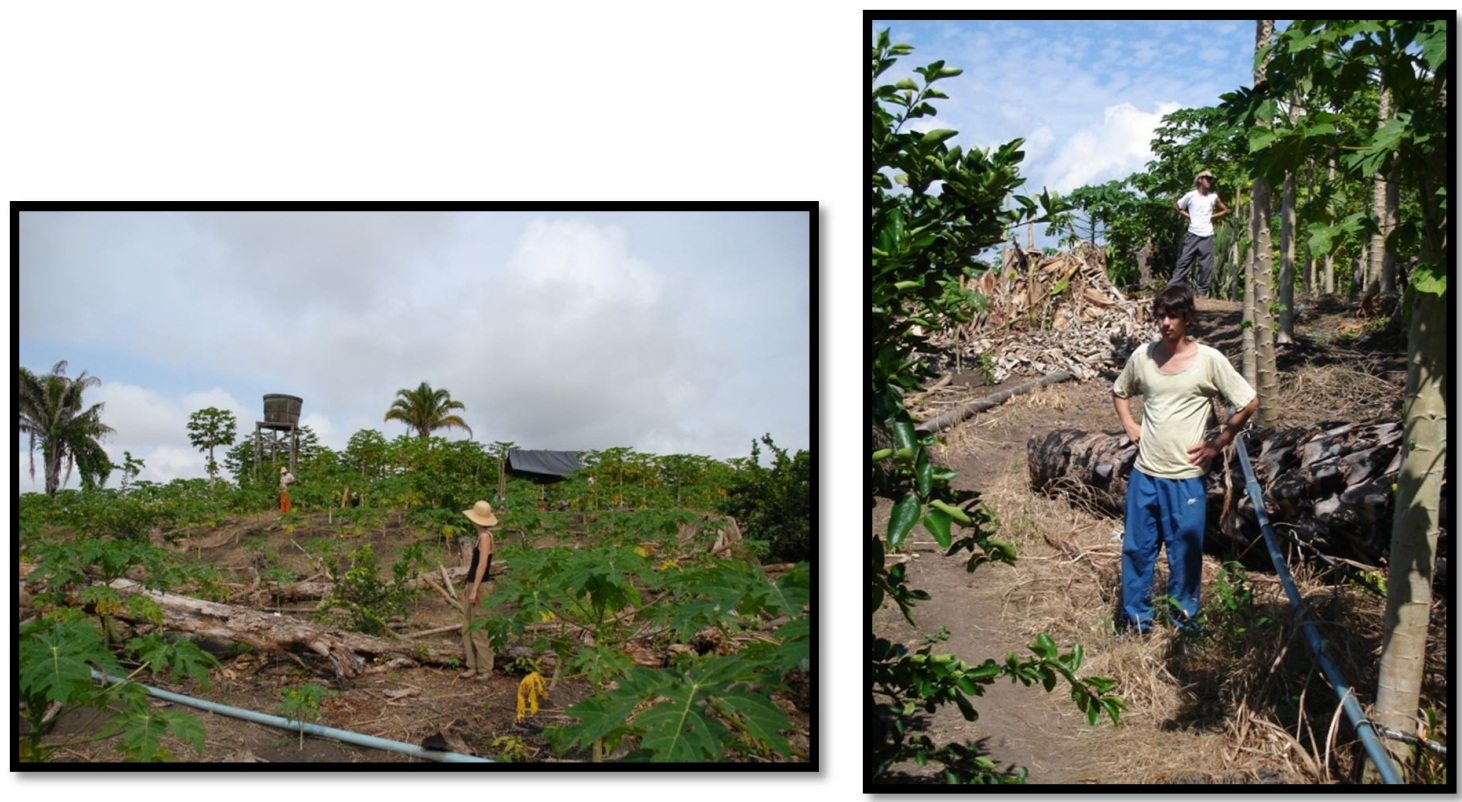

Ilustração III.7: Montículos. Sítio Laguinho (FotogRAFIAS: Acervo PAC).

(iv) Grandes tesos na llha de Marajó, PA. Denise Schaan (2010) sugere que os construtores desses tesos eram grupos pescadores que habitaram a região entre 400 e 1350 D.C. Esses grupos teriam gerido eficientemente a paisagem e alcançado complexidade social. Os tesos eram apenas uma parte do eficiente sistema hidráulico, com barragens e tanques com peixes construídos por essas sociedades que, dessa forma, conseguiam controlar a fauna aquática e o abastecimento de água nos períodos de seca. Porém, as pesquisas arqueológicas apontam para uma utilização desses locais como sítios habitacionais e cemitérios, não com campos agrícolas.

(v) Sítios com arte rupestre. Locais onde superfícies rochosas serviram de base para a elaboração de desenhos pintados ou gravados. Segundo a arqueóloga Edithe Pereira, "atualmente são conhecidos cerca de 300 lugares com arte rupestre na 
Amazônia brasileira", mas enormes áreas ainda são desconhecidas, com estudos sistemáticos ocorrendo mais intensamente apenas nas últimas duas décadas, mostrando diversificação nos "aspectos técnicos, temáticos e estilísticos" da arte rupestre amazônica (PereIRA, 2010: 261). Recentemente, novas abordagens mostram que existem semelhanças estilísticas entre motivos antropomorfos rupestres e cerâmicos e isso, para essa pesquisadora (PEREIRA, 2010), pode informar sobre a estética e o mundo simbólico das antigas sociedades, bem como auxiliar na compreensão do processo de ocupação humana regional.

(vi) Sambaquis (Ilustração III.8). São caracterizados por serem um amontoado de conchas (comuns a todos e em quantidades elevadas), ossos de peixe e mamíferos, frutos e sementes, além de sepultamentos e outros vestígios arqueológicos. Gaspar (2000) sugere que esses sítios sejam resultado de um ordenado trabalho social que tinha por objetivo, entre outras coisas, construir um importante marco paisagístico. Essa autora considera ainda que as populações que os construíram tinham complexidade social e uma cultura bem adaptada ao ambiente em que viviam. Na Amazônia, eles estão associados a ocupações bastante antigas, remontando há "7.600 anos AP no baixo Amazonas, 6.600 anos AP no Maranhão e 5.500 anos AP no Pará" (SILVeIRA e SCHAAN, 2010: 46) e possuem a particularidade de apresentarem vestígios cerâmicos. Embora citem essas datações, esses autores advertem que as pesquisas realizadas em sambaquis ainda são insuficientes para que se obtenham dados cronológicos e culturais mais consistentes sobre esses povos amazônicos e, portanto, é essencial a preservação desses sítios. 

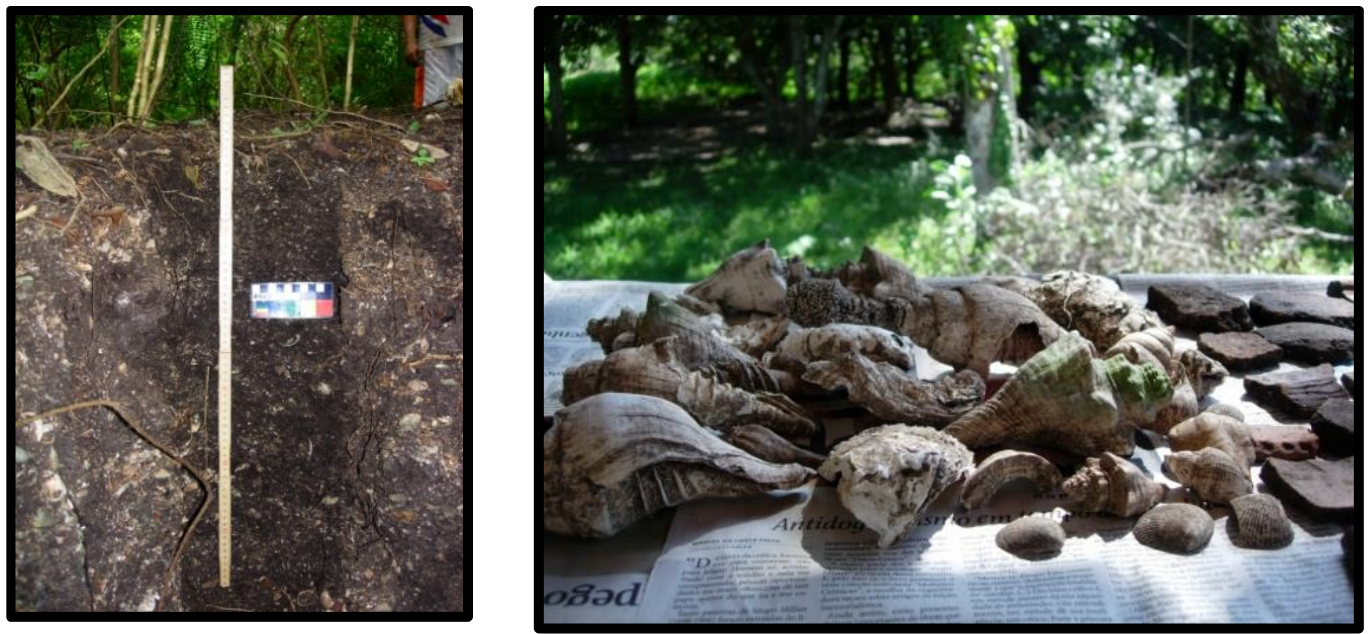

Ilustração III.8: Sambaqui do Bacanga e vestígios típicos, Maranhão (FotogRAFIAS: Adriana Guimarães, 2006).

(vii) Sítios com estruturas megalíticas no Amapá. Compostos por blocos inclinados, cuidadosamente inseridos no solo, encaixados em outros blocos menores como uma fundação para dar estabilidade ao conjunto. Ao escavar a base dessas estruturas, Saldanha e Cabral (2010) identificaram densas e variadas deposições cerâmicas. Esses autores informam sobre a diversidade desses conjuntos megalíticos, em relação à forma das estruturas (circulares, lineares, irregulares), à forma das vasilhas encontradas e as suas decorações, ao modo de deposição dos conjuntos, finalmente, à manipulação (ou ausência de manipulação) de restos funerários - e sugerem que "pensar a possibilidade de um histórico antigo de redes nessa região pode ajudar a explicar algumas questões" ainda em aberto para a arqueologia local e regional (SALDANHA E CABRAL, 2010:58).

(viii) Geoglifos no Acre, Rondônia e Amazonas (llustração III.9). Esses sítios, "verdadeiros monumentos da engenharia humana" (RANZI, 2010: 09), são estruturas de terra que desenham no solo figuras geométricas (em sua maioria circulares e retangulares, mas também elipses, hexágonos, octógonos, figuras em U e em D), delimitando, em geral, espaços internos que vão de 1 a 3 hectares, com média de 137,5 metros de diâmetro (SCHAAN, 2010). Em 2010, graças ao auxílio do Google Earth, que permite a visualização perfeita de muitas dessas 
estruturas, já se conheciam 270 estruturas, embora nem todas tenham sido visitadas e nomeadas. Quanto à importância desses locais, Denise Schaan salienta que (2010: 13):

[a]importância desses sítios é inequívoca, pois o trabalho envolvido em sua construção, por parte de grupos indígenas que ali viveram há dois mil anos, sem a ajuda de modernas ferramentas para escavar e transportar toneladas de solo, indica que teria sido necessário um esforço coordenado de muitos braços, instruídos para a construção de gigantescas estruturas cuja precisão geométrica e consistência de medidas indicam planejamento meticuloso.

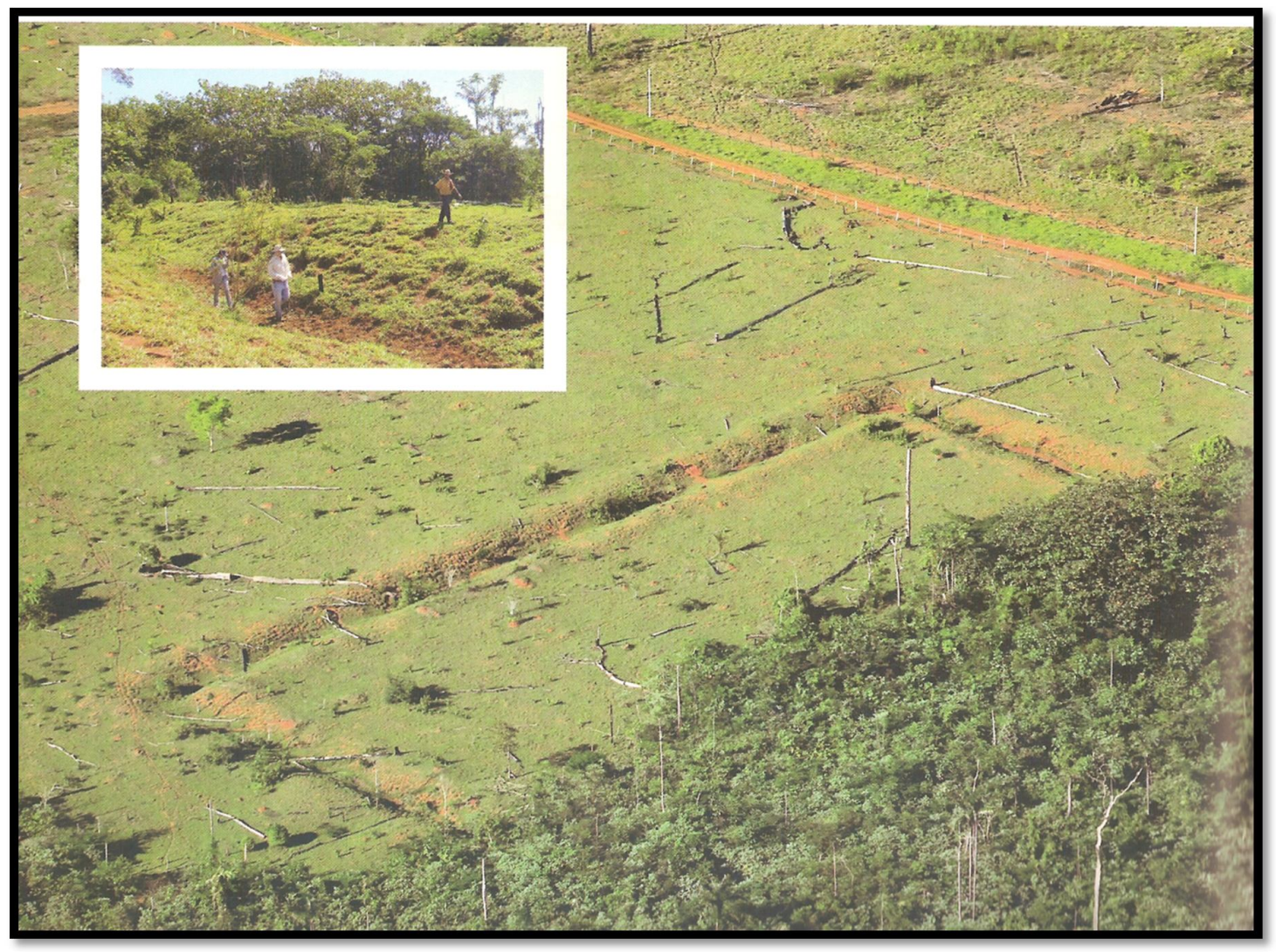

llustração III.9: Cachimbo, Acrelândia. (FotografiAs: Denise Schaan (menor) e Diego Gurgel (maior). FONTE: SCHAAN et al., 2010).

Fora a diversidade de sítios, também são observados modos de sepultamento distintos (RAPP PY-DANIEL, 2009), diferenças na produção das cerâmicas (LIMA, 2008), bem como são encontrados indícios de estratos sociais diferenciados e especialização do trabalho. Tais dados apontam para uma grande diversidade cultural no passado da região (RAPP PY-DANIEL 
et al., 2011), que, em certa medida, ainda se mantém nos dias de hoje. Por isso, Eduardo Neves (2006: 22) afirma que:

(...) a diversidade é a chave para o entendimento da arqueologia amazônica. Nada mais distante, portanto, de uma certa visão tradicional que enxerga a Amazônia como um grande ecossistema homogêneo - seja ele um inferno verde ou um paraíso perdido - ocupado por grupos essencialmente iguais entre si.

O fato é que essas pessoas sobreviveram ao ambiente de floresta tropical por bastante tempo e, para isso, precisaram criar modos de vida próprios, porém distintos entre si. Os dados arqueológicos estão rascunhando essas diferenças, mas ainda é difícil compreendê-las integralmente nos cenários da Amazônia antiga.

Nordenskiold (1929) já revelava "invenções" indígenas que contribuíram para a sobrevivência dos grupos locais, incluindo o cultivo de diversas plantas, em níveis diferentes. Nesse sentido, é muito pertinente considerar que o cultivo não é uma atividade simples, requerendo seleção das sementes, das espécies e cuidados específicos contra pragas e animais. A mandioca, por exemplo, citada por ele, sem dúvida é a que mais impressiona, pois é altamente venenosa. Isso, de fato, era uma vantagem que permitia a sua produção em grande escala, já que as plantas não eram atacadas por outros animais. Para utilizá-la, no entanto, os índios desenvolveram um método capaz de extrair o veneno e, também, de fabricar um subproduto apto a se manter íntegro por um longo tempo no ambiente úmido local (a farinha), o que o tornava um alimento indispensável às populações sedentárias. $\mathrm{Na}$ verdade, existiam outras variedades de mandioca, algumas com menor poder de intoxicação, hoje conhecidas como mandiocas doces, que também eram utilizadas (Ilustração III.10).

O mesmo autor (NORDENSKIOLD, 1929) cita também o cacau, a pupunha e o tucumã como espécies já conhecidas e aproveitadas pelos indígenas locais, além de outras consideradas medicinais, como o guaraná e a copaíba, da qual se extrai um óleo (ao qual se atribuem propriedades antibacteriana, desinfetante, diurética e estimulante) e uma resina (antiinflamatória, antifúngica e analgésica), embora doses altas dessa planta possam ser 
tóxicas ${ }^{80}$. O açaí, a bacaba, o patauá e a castanha também foram consumidos por populações amazônidas antigas (NEVES et al., 2003).

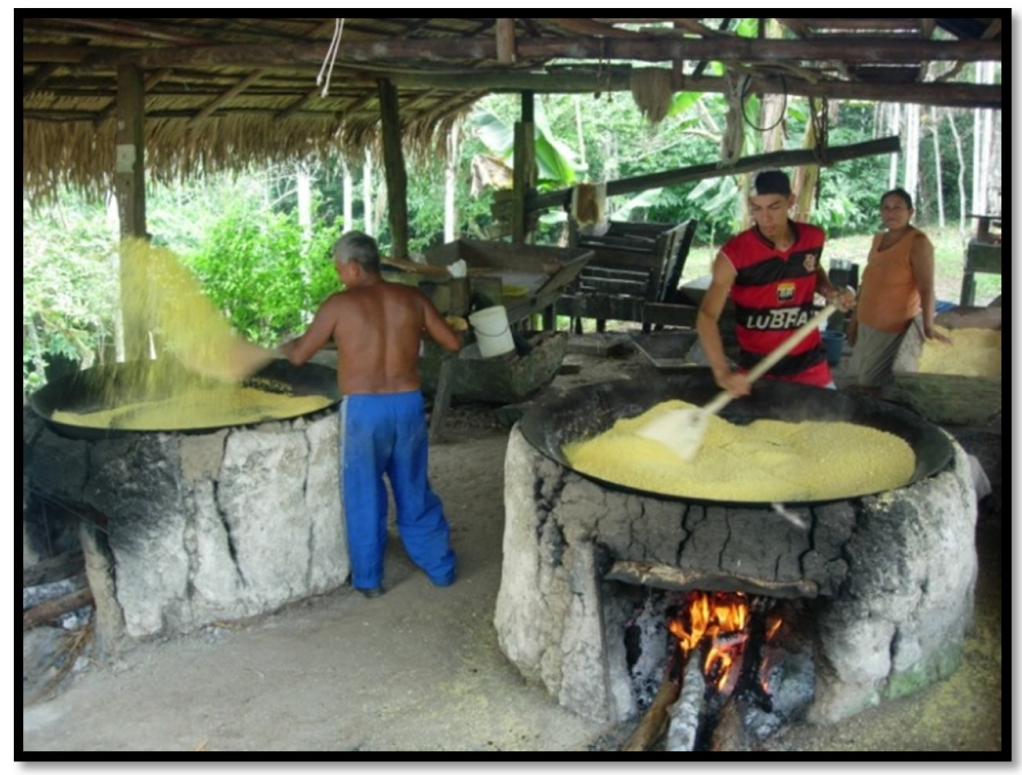

Ilustração III.10: Fabricação de farinha de mandioca, processo de torra. Lago do Limão, Iranduba, AM. (FotOGRAFIA: Adriana Guimarães, 2006).

Além das plantas cultiváveis, Nordenskiold conta que os índios produziam ferramentas para trabalhar, muitas delas para a preparação de fibras, e lembra que a adição de espículas de esponjas aquáticas (cauixi) ao barro, na manufatura das cerâmicas, não era conhecida em nenhuma outra parte do mundo (Ilustração III.11). Isso as fortalecia, proporcionando-Ihes

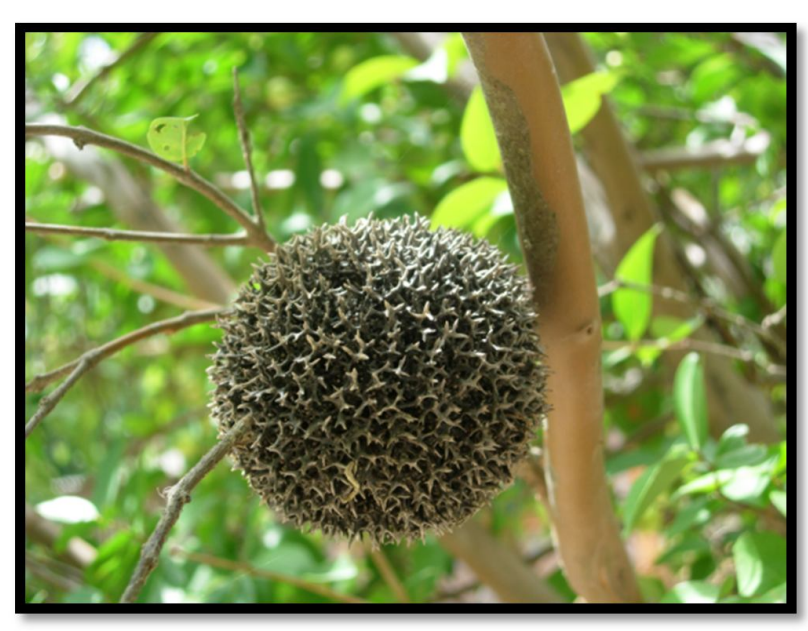

durabilidade, assim como fazem as barras de ferro no cimento na montagem do concreto, e permitia a adoção de formatos diferenciados (NORDENSKIOLD, 1929: 281).

Ilustração III.11: Cauixi preso em um galho de árvore depois da cheia e seca do rio. Silves, AM. (FotograFIA: Adriana Guimarães, 2010).

\footnotetext{
${ }^{80}$ Informações sobre a Copaíba retiradas do site: http://www.plantasmedicinaisefitoterapia.com/plantas-medicinais-copaiba.html. Acesso: fev./2012.
} 
Para Hornborg (2005), essas pessoas, já no primeiro milênio A.C., viviam em sociedades densamente populosas, ocupando grandes áreas de várzea, e seriam caracterizadas por extensas alianças étnicas e hierarquias de poder com base no comércio de longa distância e na exploração intensiva de recursos terrestres e aquáticos. Esse autor propõe que, em torno de 500 A.C., "algo novo" teria ocorrido simultaneamente em vastas áreas da Amazônia, aumentando o grau de sedentarização das aldeias, bem como os espaços por elas ocupados e, desse modo, intensificando a geração da Terra Preta (PETERSEN et al., 2001 apud HoRnBorg, 2005). Eduardo Neves (2010: 37), por sua vez, sugere que, no ano 1000 da era cristã, a Amazônia possuiria sociedades indígenas, "algumas hierarquizadas, lideradas por chefes supremos, capazes de comandar um exército de guerreiros", outras formadas por pequenos grupos nômades. Isso, ressalve-se, não é uma questão de atraso cultural, mas sim de escolhas conscientes desses grupos.

Miranda (2007: 47) acredita que seja um paradoxo que a região aparentemente "mais preservada do Brasil" seja "aquela onde o homem vive há mais tempo e de forma mais permanente". Pensa-se que não há nenhuma contradição nessa relação. Ao contrário, ela só indica que a substituição dos modos de vida locais não foi benéfica para a floresta. Essa é, portanto, a lição mais valiosa que a arqueologia amazônica pode legar ao seu objeto de estudo: direcionar esforços para entender os modos de vida desses grupos, a abrangência de suas ocupações e o real impacto de suas presenças, positivo ou negativo, nesse ambiente.

\section{1. Projeto Amazônia Central.}

O Amazonas é o maior estado brasileiro em área, com mais de 1,5 milhão de $\mathrm{km}^{2}$, dos quais 92\% são cobertos por floresta. É o segundo mais populoso da região Norte (3.483.985), mas possui baixa densidade demográfica (2,3 hab./Km2). Abriga o maior número de índios do Brasil, com 55\% da população residente sendo considerada indígena (IBGE, 2010). O estado 
sofre com a falta de infraestrutura na maioria dos seus municípios, possui altas taxas de mortalidade infantil, de analfabetismo e analfabetismo funcional.

Desde 2003, uma parte do estado foi inserida na listagem de patrimônios naturais da humanidade sob o título de Complexo de Conservação da Amazônia Central (UNESCO):

The Central Amazon Conservation Complex makes up the largest protected area in the Amazon Basin (over 6 million hectares) and is one of the planet's richest regions in terms of biodiversity.

The site is made up of Jaú National Park, Demonstration area of Mamairauá Sustainable Development Reserve, Amanã Sustainable Development Reserve and the Anavilhanas Ecological Station located in Amazonas State. The site includes an important sample of annually flooded (várzea) ecosystems, igapó forests, lakes and channels which take the form of a constantly evolving aquatic mosaic that is home to the largest array of electric fish in the world ${ }^{81}$.

Sobre a área de confluência dos rios Negro e Amazonas, considera-se que "como entroncamento biológico, os arredores de Manaus são de importância crítica para a conservação, não só pela alta biodiversidade apresentada, mas pelos importantes processos evolutivos que continuam a se processar por lá" (DALY, 2001: 59).

Iniciadas por Hilbert no final da década de 50, as pesquisas arqueológicas na região de Manaus sempre se mostraram bastante produtivas e muito do que foi produzido naquela época ainda norteia as pesquisas atuais. A região foi pesquisada posteriormente, nas décadas de 70 e 80, pelo arqueólogo Mário Simões, que foi o responsável pela identificação e registro de diversos sítios. Depois disso, a arqueologia dessa região sofreu com um período de inércia que só foi quebrado com o início dos trabalhos do PAC (LAMA, 2007).

Surgido da curiosidade em relação à possibilidade de ali ter sido um grande centro de inovação cultural do passado, conforme a hipótese de Lathrap (1970), três amigos resolveram investigar os aparentemente grandes sítios de Terra Preta na região de Iranduba. Eduardo Neves, James Petersen e Michael Heckenberger conseguiram apoio de Billy Hillman, amigo deste último pesquisador, que, através da sua ONG americana Hillman Foundation,

${ }^{81}$ O Complexo de Conservação da Amazônia Central comporta a maior área protegida da Bacia Amazônica (mais do que 6 milhões de hectares) e é uma das regiões mais ricas do planeta em termos de biodiversidade. Esta área é constituída pelos Parque Nacional de Jaú, espaço de demonstração da Reserva de Desenvolvimento Sustentável do Mamirauá, Reserva de Desenvolvimento Sustentável do Amanã e Estação Ecológica de Anavilhanas, localizada no Estado do Amazonas. Ela inclui ecossistemas que são inundados anualmente (várzea), florestas de igapó, lagos e canais, que assumem a forma de um mosaico aquático em constante evolução, o qual abriga a maior quantidade de peixes elétricos do mundo [Tradução: Luciana M. Guimarães]. 
viabilizou a primeira etapa de campo na região, em 1995. Os resultados animaram os pesquisadores a seguirem no propósito de entender a história antiga daquele local.

O projeto ganhou corpo em 1999 a partir do financiamento da Fundação de Amparo à Pesquisa do Estado de São Paulo (FAPESP), que possibilitou a participação de novos pesquisadores, em sua maioria alunos do MAE/USP.

As características dos sítios locais, que a cada etapa de campo mostravam-se mais complexos, foram demandando o envolvimento de um número cada vez maior de arqueólogos. Assim, a cada ano, mais estudantes e pesquisadores agregaram-se ao projeto. Com isso, cresceu também a necessidade de novos aportes financeiros que viabilizassem a continuidade das pesquisas. Foi quando, em 2002, surgiu a possibilidade de o MAE/USP participar dos EIA do Gasoduto Coari-Manaus, sob coordenação de Neves, que aceitou o desafio, encarando-o como a possibilidade de (i) expandir a área pesquisada, já que o duto percorreria cerca de 400 km, (ii) de capacitar mão-de-obra local para atuação em projetos de arqueologia, bem como de atrair para o Amazonas arqueólogos em formação para que os mesmos se fixassem por lá e (iii) de criar no Amazonas um espaço viável para análises, acolhimento e guarda de todo material arqueológico regional através da construção de um grande centro de arqueologia regional, o Centro de Arqueologia dos Biomas Amazônicos (CABA).

Dessa forma, o PAC tentaria inverter uma prática arqueológica colonialista que, frequentemente, retira os materiais dos locais pesquisados e os deposita em grandes centros, quase sempre muito distantes dos locais de origem, sob a alegação de que os mesmos não possuem infraestrutura física, nem profissionais habilitados para os seus tratamentos e guarda, e daria um grande passo na geração e difusão do conhecimento arqueológico regional. Embora o raciocínio de Neves se pautasse em premissas humanitárias, e estivesse alinhado à preocupação do IPHAN com a ausência de um local que recebesse todos os vestígios provenientes dos EIA do gasoduto (o que, por pouco, não inviabilizou os estudos), a sua exigência para que o dinheiro fosse gerido pelo MAE/USP foi, aparentemente, entendida como intencionalmente oposta e tornou-se uma primeira rusga no relacionamento entre o PAC e o governo estadual. 
De todo modo, foi implantado um laboratório de arqueologia temporário na cidade de Manaus, onde seriam mantidos e tratados todos os materiais advindos do gasoduto CoariManaus até a construção do local definitivo. O laboratório abrigou também vestígios provenientes de projetos de pesquisa no âmbito do PAC, bem como de novos projetos desenvolvidos por arqueólogos que foram formando-se e fixando-se em Manaus. 0 laboratório acolheu milhares de peças e viabilizou exposições, filmagens, reportagens e, inclusive, nos seus últimos anos, serviu de apoio ao curso de arqueologia da Universidade do Amazonas (UEA). Este curso, salienta-se, foi incentivado pelo PAC e coordenado por arqueólogos por ele tecnicamente aperfeiçoados, como Helena Lima, atualmente pesquisadora na Universidade Federal do Amazonas (UFAM) e Anne Py-Daniel, hoje atuando na Universidade Federal do Oeste do Pará (UFOPA). Deve-se ressaltar que o empenho do PAC na formação de jovens arqueólogos, especializados em Amazônia, surtiu tanto efeito que parte dos docentes do curso de arqueologia desta última universidade é egressa desse projeto (p. ex. os professores Anne Py-Daniel, Claide Moraes e Lilian Rebellato).

Em 2005, justamente quando o PAC completava 10 anos, um acontecimento trágico marcou seus participantes. James Petersen foi assassinado num restaurante na rodovia que liga Iranduba a Manacapuru, em frente a alguns dos seus colegas. Naquele ano, a etapa de campo, que ocorria no Lago do Limão, foi suspensa, sendo retomada apenas no ano seguinte.

Para homenagear o amigo, sugeriu-se que o CABA fosse localizado justamente no Lago do Limão. O dinheiro para a criação do centro seria proveniente das medidas compensatórias relacionadas à construção do gasoduto Coari-Manaus. A destinação já estava oficializada, tendo sido anunciada por um funcionário da Petrobrás no Seminário Internacional de Gestão do Patrimônio Arqueológico Pan-Amazônico, promovido pelo IPHAN, em Manaus, no ano de 2007. No ano seguinte, por ocasião do I Encontro Internacional de Arqueologia Amazônica, em Belém, foi apresentado um pôster que mostrava o encaminhamento adiantado dos projetos arquitetônicos para o CABA (Anexo 1). Porém, ajustes políticos, incluindo o que pode ser considerado falta de visão no que concerne ao desenvolvimento sociocultural e econômico regional, rejeitando a construção do CABA em Iranduba e/ou ignorando o seu potencial científico, bem como indutor de desenvolvimento socioeconômico, fizeram com que o Centro não saísse do papel. Segundo consta, o dinheiro destinado à construção do 
espaço que abrigaria as imensas e importantes coleções arqueológicas do estado havia sido investido na estruturação do Palacete Provincial, transformado num centro cultural que reúne cinco museus estaduais, incluindo um de arqueologia. Porém, neste local, não há espaço para abrigar todas as peças de somente uma etapa de campo, dos quase 20 anos de PAC. A crise econômica de 2008 serviu como a última justificativa para todas essas mudanças de planos.

Todo esse processo foi altamente desgastante e gerou inúmeros conflitos entre o PAC e as entidades políticas locais. Conflitos tais que, em 2012, ainda seguem tramitando judicialmente. Com o encerramento do laboratório de Manaus, as peças foram transferidas para um depósito na UFAM, que se dispôs a recebê-las, mas sem a infraestrutura requerida para tanto.

\section{2. O Potencial para o Turismo ARQUeOlógico na Região do PAC.}

É inquestionável o potencial da Amazônia para o turismo. Além das inegáveis belezas naturais, a região possui inúmeras particularidades culturais, abrigando centenas de comunidades indígenas e caboclas, com modos de vida adaptados à realidade amazônica.

No estado do Amazonas, que é o principal portão de entrada de turistas para a Amazônia brasileira, foram 37.135 entradas em 2009, com uma queda para 26.423 em 2010 (aproximadamente 0,5\% do total nacional). Desses, 13.912 foram turistas com residência permanente na América do Norte, seguidos por turistas residentes na própria América do Sul (4.807), Europa (4.058) e Ásia (2.691) (BRASIL, 2011).

Observa-se, portanto, que embora a Amazônia tenha um apelo atrativo muito grande (Ilustração III.12), o fluxo atual ainda é muito pequeno frente ao seu potencial, com atração concentrada nos emissores mais próximos: as Américas. 

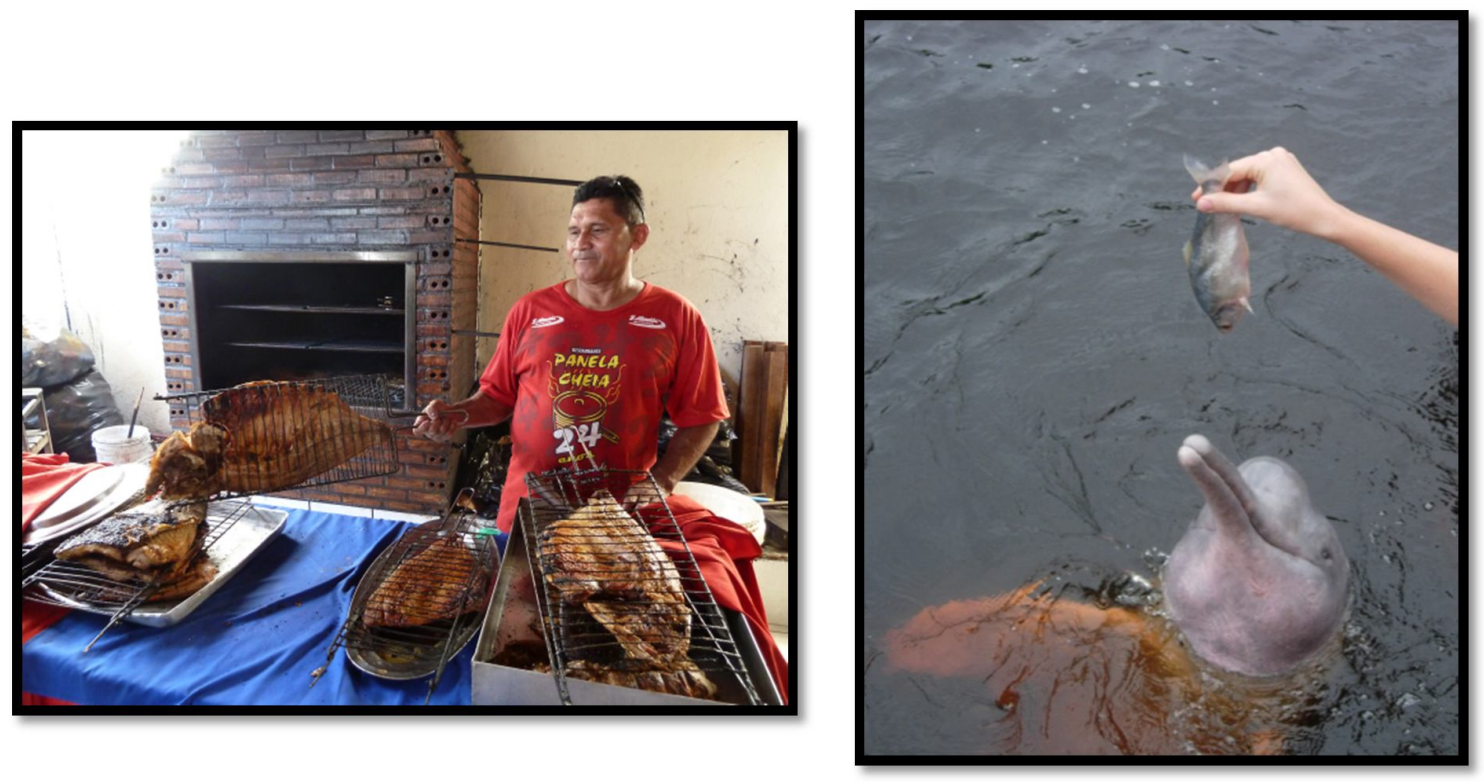

Ilustração III.12: Costela de Tambaqui assada na brasa, prato típico da comida amazonense (à esquerda) e boto cor de rosa (à direita) (FotografiAs: Adriana Guimarães).

Em análise para desenvolver um Plano de Incentivo ao Turismo regional, o Banco da Amazônia (2008) percebeu que o potencial turístico local é ameaçado por fatores inibidores, como a carência de produtos turísticos formatados, a insuficiência e fragilidade das informações turísticas, a difícil acessibilidade, o elevado custo dos produtos, a infraestrutura deficitária e a pouca divulgação/promoção nos mercados interno e externo.

O turismo hoje praticado na Amazônia brasileira pauta-se, basicamente, em sua floresta e rios, funcionando quase espontaneamente (BANCO DA AMAZÔNIA, 2008; LOBATO NETO, 2001). Essa é uma lógica imediatista, proporcionada por tais atrativos fortes, os quais requerem muito pouco para serem acessados. Em muitos casos, os atrativos locais possuem pouca ou nenhuma infraestrutura e capacitação dos envolvidos, mas, mesmo assim, são inseridos no mercado turístico. Tal turismo, sem planejamento e investimento, tende à insustentabilidade e se deveria questionar, até mesmo, a sua tipificação como Ecoturismo. Isto, porém, não é o foco deste trabalho.

Desde 2001, estudos já apontavam um outro problema crucial (LOBATO NETO, 2001): 
(...) o desenvolvimento do turismo na Região necessita, de fato, é de vontade política para implementar as ações e destinar os recursos financeiros para a realização dos investimentos necessários, principalmente na infra-estrutura básica urbana e turística de acesso, cuja maior responsabilidade recai no poder público.

Enfim, são muitas as dificuldades para o desenvolvimento turístico regional. Os dados apresentados alertam que, embora se esteja falando de uma área que equivale a $60 \%$ do território nacional, turisticamente, a região amazônica está sendo subaproveitada. Prova disso é que o MTur apresenta toda a região Norte do país a partir de apenas onze destinos principais e onze opções de roteiros, a maior parte deles com temas ligados à cultura e ao ecoturismo, sendo que a parte cultural, em geral, fica por conta das comunidades indígenas e caboclas.

O MTur não fala em Turismo Arqueológico na Amazônia brasileira. Porém, deve-se relembrar que a atividade já se desenvolve, em maior ou menor grau, em alguns locais. Andrade (2007), em estudo já apresentado nesta tese, cita oito sítios, por ela classificados como de "ação planejada", de um total de pelo menos vinte sítios expostos à visitação pública na região. São eles (ANDRADE, 2007: 46-49):

Macapá, AP. Fortaleza São José de Macapá (planejada)

Alenquer, PA. Cidade dos Deuses (nãoplanejada)

Belém, PA. Forte do Presépio (planejada)

Belém, PA. Fortaleza de São Pedro Nolasco (planejada)

Belém, PA. Presídio São José (planejada)

Monte Alegre, PA. Gruta Itatupaoca, Gruta do Pilão, Pedra do Pilão, Pedra do Mirante, Painel do Pilão, Serra da Lua. (não planejada)

Óbidos, PA. Serra da Escama. (não planejada)

Óbidos, PA. Fortaleza Gurjão. (--)

Óbidos, PA. Forte de Óbidos. (planejada)

Salvaterra, PA. Sem nome. (não planejada)

Salvaterra, PA. Vila de Joanes. (planejada)

São Geraldo do Araguaia, PA. Pedra Escrita, Ilha dos Martírios, Abrigo Neblina. (não planejada)

Costa Marques, RO. Forte Príncipe da Beira. (planejada)

Pacaraima, RR. Pedra Pintada (não planejada) 
Desse modo, é de admirar que, oficialmente, não se fale em Turismo Arqueológico no Norte do país, nem como Turismo Cultural. Expandindo a análise, pode-se raciocinar em cima de dois exemplos, dentre os destinos turísticos listados pelo MTur, onde arqueologia se destaca e não deveria ter passado despercebida: as cidades de Belém e Santarém, no Pará. Há nelas, pelo menos, museus voltados ao tema. Em Belém, encontra-se o Museu Paraense Emílio Goeldi, uma das instituições voltadas à pesquisa arqueológica de maior expressividade no Brasil, possuidora de um rico acervo arqueológico e muito atuante em pesquisas arqueológicas regionais, além de outros pequenos museus que dedicam-se ao tema e encontram-se bem estruturados. Santarém - que possui vestígios cerâmicos diferenciados no contexto amazônico e de grande apelo estético - conta com um museu voltado à arqueologia local que, embora pequeno e sem investimentos para apresentação adequada do acervo ao público, impressiona pelas peças da cultura tapajônica, uma das mais belas e refinadas cerâmicas antigas do país. Esta cidade possui, ainda, algumas praças com decoração inspirada em seus vestígios arqueológicos. A decoração das cerâmicas arqueológicas encontradas na Ilha de Marajó (Marajoara) e em Santarém (Tapajônica) serve de inspiração para a fabricação de objetos de decoração e utilitários, bem como de réplicas que são largamente difundidas por todo o estado, constituindo-se num dos principais souvenirs vendidos aos visitantes. Desta maneira, é impossível que isso passe despercebido em um bom inventário de atrativos turísticos regionais. E esses não são os únicos municípios com grande potencial arqueológico na Amazônia brasileira. Ainda que sobrem opções, parece faltar atenção no que tange ao desenvolvimento de produtos arqueoturísticos ou à utilização do grande potencial já conhecido.

O estado do Amazonas é apresentado pelo MTur (âmbito federal) a partir de apenas quatro destinos (os três primeiros destinos são considerados indutores da atividade turística na região):

Barcelos (Ecoturismo, Pesca e Aventura)

Manaus (Ecoturismo, Cultural, Náutico, Pesca, Negócios e Eventos)

Parintins (Cultural, Ecoturismo e Pesca)

Parque Nacional de Anavilhanas.

Este último, segundo consta, insere-se em uma proposta de roteiro turístico, "conjugando os atrativos naturais do parque com os naturais e culturais do entorno". Atente-se para o fato, 
no entanto, que nesse entorno encontra-se o município de Novo Airão, em cuja descrição o MTur assume publicamente ignorar a arqueologia enquanto atrativo significativo ${ }^{82}$ :

O Município de Novo Airão possui oferta essencialmente ligada à Natureza. No total $84,8 \%$ dos atrativos são naturais e apenas $12,2 \%$ são culturais. Entretanto, percebe-se que o grande potencial da região está associado à Arqueologia (inúmeros artefatos e sítios históricos que contam a história de uma região de grande pujança econômica no passado). Entretanto, o atrativo mais divulgado em Novo Airão é o Flutuante do Boto.

Esta informação parece priorizar, explicitamente, o Flutuante do Boto em detrimento do "grande potencial" arqueológico identificado pelo próprio MTur, que não explica as razões deste posicionamento.

O Amazonas expandiu a listagem do MTur e selecionou outros municípios para compor seu polo ecoturístico. Além de Manaus, Barcelos e Parintins, entraram para a relação os municípios de "Autazes, Careiro, Careiro da Várzea, Iranduba, Manacapuru, Novo Airão, Itacoatiara, Presidente Figueiredo, Rio Preto da Eva, Silves, Santa Isabel do Rio Negro e São Gabriel da Cachoeira" (BANCO dA AMAZÔNIA, 2009).

Além do Ecoturismo, o turismo no estado do Amazonas está segmentado em Turismo de Pesca, de Aventura, Cultural, Fluvial. O estado é apresentado como "o destino verde do Brasil”. Em 2009, na publicação Folha do Turismo ${ }^{83}$, o destino Amazonas define o segmento cultura da seguinte forma:

\section{A autêntica expressão dos povos da floresta}

A riqueza oferecida pela cultura amazonense, que recebeu uma considerável influência dos povos indígenas, está presente em nossa música regional, bem como nas artes plásticas, artesanato e nas manifestações folclóricas. Um exemplo disso é o Boi-Bumbá de Parintins, que já conquistou prestígio internacional e todo ano atrai milhares de visitantes para a pequena cidade do Baixo Amazonas, para assistir ao grande espetáculo que conta as lendas da Amazônia, retrabalhando aspectos indígenas. Em Manaus, uma grande programação cultural pode ser conferida o ano inteiro, desde o Carnaboi no sambódromo, em fevereiro, até o Boi Manaus, em outubro, passando pelo festival Folclórico do Amazonas, em junho. No interior, diversos municípios também realizam suas festas próprias como Manacapuru, com seu Festival de Cirandas, ou o Festival da Canção em Itacoatiara, com artistas e compositores locais e nacionais.

82 Fonte: http://www.turismobrasil.gov.br/promocional/destinos/P/Parque Anavilhanas.html. Acesso: fev./2011.

${ }^{83}$ Edição Salão do Turismo - São Paulo - Julho 2009. 
Embora o site da Empresa Estadual de Turismo do Amazonas (AMAZONASTUR) afirme que ${ }^{84}$ "[a] riqueza de seu patrimônio natural e cultural credencia o Estado para a prática do ecoturismo, confirmando sua vocação para o desenvolvimento dessa modalidade de turismo" (ênfase desta autora), supõe-se, devido à ausência de referências ao assunto, que a arqueologia não esteja sendo percebida como patrimônio cultural a ser aproveitado turisticamente.

O esforço para gerar o conhecimento arqueológico local parece ainda não estar sendo absorvido pelo poder público como um todo. Diz-se isso porque, embora a pré-história do Amazonas seja riquíssima, como já descrito, o Estado insiste em apresentar oficialmente a história local a partir da "Descoberta do Estado da Floresta" ${ }^{\prime 85}$ pelo espanhol Francisco de Orelhana, indo na contramão do restante do país que já questiona o uso do termo 'descobrimento' e busca reconhecer a presença de habitantes autóctones e revisar a história nacional. Outro exemplo disso pode ser obtido na observação da sala dedicada à arqueologia local no Museu de Arqueologia no Palacete Provincial, também já citado anteriormente. Neste local, existe apenas uma pequena exposição sobre a arqueologia local, com algumas fotos e peças, enquanto que a exposição com réplicas de vestígios arqueológicos internacionais, como réplicas de artefatos paleolíticos, tem lugar de destaque no prédio.

No entanto, mesmo sem que haja um planejamento específico para tal, o patrimônio arqueológico tem sido inserido em roteiros turísticos locais. O que acontece no município de Presidente Figueiredo é exemplo emblemático. Devido à existência de grutas com pinturas rupestres, o aproveitamento turístico do patrimônio arqueológico segue a mesma lógica imediatista descrita anteriormente: insere-se no mercado turístico aquilo que poderá atrair facilmente, mesmo sem planejamento e estruturação para tal. Uma lógica perigosa, que aponta para a necessidade absoluta de mudanças na mentalidade política local.

De maneira geral, a relação comunidade $x$ visitantes $x$ patrimônio tem sido, quase sempre, desastrosa. Na melhor das hipóteses, o material passa a ser recolhido pela comunidade, que

${ }_{85}^{84}$ Fonte: http://www.amazonastur.am.gov.br/programas 02.php?cod=0093. Acesso em: 06/08.

85 Fonte: Portal do Governo do Estado do Amazonas. Endereço: http://www.amazonas.am.gov.br/pagina interna.php?cod=13. Acesso em: 08/2011. 
vai o acumula sem o cuidado com o registro da proveniência ou com o seu processo de guarda (Ilustração III.13). É muito comum que o material seja vendido para os visitantes, apesar da ilegalidade do ato. Há relatos de comunidades que chegam a quebrar peças encontradas inteiras para que as mesmas possam ser vendidas com mais facilidade para os forasteiros. Porém, mesmo com muitas comunidades habitando, literalmente, sobre sítios arqueológicos, não foi possível detectar nenhum projeto específico, público ou particular, que se voltasse à implementação do Turismo Arqueológico até 2008, quando as ações descritas nessa tese foram iniciadas.

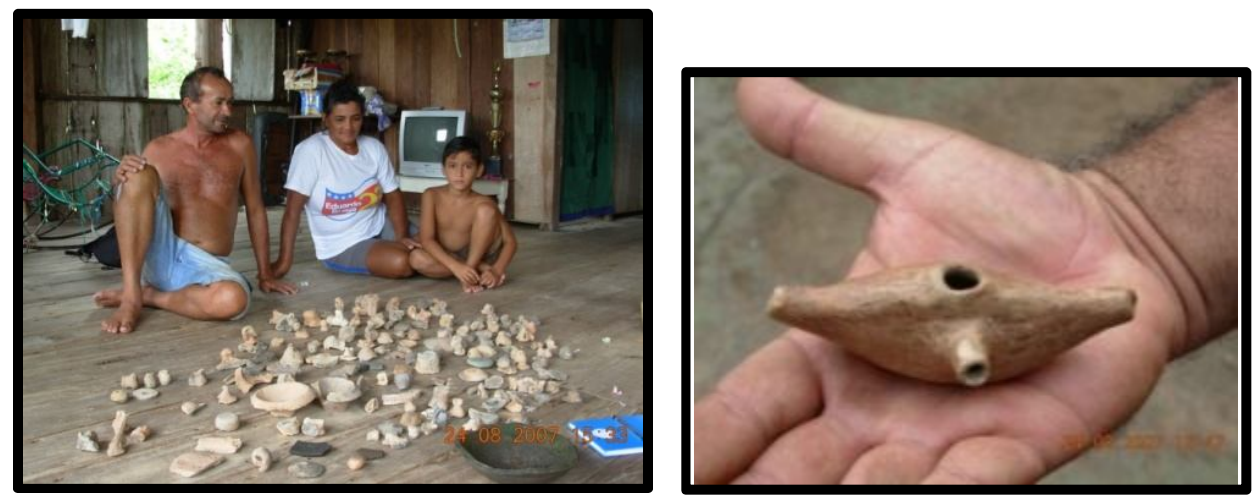

Ilustração III.13: Objetos sob a guarda de comunitários no Amazonas (FotogRAFIAS: Adriana Guimarães, 2007).

III.2.1. O MUNICÍPIO DE IRANDUBA.

As origens do município se prendem à Manaus. A capital do estado conheceu época de grande prosperidade na última década do século com o auge da era da borracha. Passado este fastígio, Manaus experimentou período de estagnação e até retrocesso. Com a implantação da Zona Franca e do Distrito Industrial, reativou-se a economia do município, florescendo em sua periferia vários núcleos populacionais. Entre eles está Iranduba, que, sobretudo a partir de 1976, veio recebendo consideráveis melhoramentos urbanos.

Em 09.04.1963, pela Lei no 07, o município de Iranduba foi criado, tendo como governador em exercício o Sr. Anfremon D’Amazonas Monteiro.

Em 24.07.1964, pela Lei № 41, o Governador Arthur César Ferreira Reis extingue o município Em 10.12.1981, pela Emenda Constitucional no 12, é desmembrado de Manaus e, acrescido de território adjacente até então pertencente a Manacapuru, passa a constituir município autônomo, pelo Governador José Lindoso. 
Em 1982, efetuou-se sua instalação com as eleições gerais e conseqüentemente com a posse de prefeito e vereadores em janeiro de 1983. (Governo do Estado do Amazonas ${ }^{86}$ )

Iranduba, área principal de abrangência do PAC, possui população estimada em 40.628 pessoas (IBGE, 2010). O município, assim como tantos outros no país, sofre com altas taxas de mortalidade infantil, analfabetismo e falta de emprego, sendo que a economia local centra-se, principalmente, na produção cerâmica. Na estrada Manoel Urbano, que corta o município, é possível observar a existência de diversas olarias que produzem toneladas de telhas e tijolos, envolvendo, diretamente ou indiretamente, muitas pessoas. Essas dezenas de olarias, de variado porte, ocupam diretamente cerca de duas mil pessoas e operam, quase todas, com fornos a lenha. A extração de madeira no seu entorno rural é tão intensa que o índice de desmatamento local chega a $15 \%$, em confronto com os $2 \%$ do conjunto do estado (KRAMER, 2008).

O abastecimento dos fornos das olarias com madeiras retiradas ilegalmente gera um grande impacto ambiental. O aumento da fiscalização para o cumprimento da legislação ambiental tem provocado uma redução drástica na produção local. Além disso, a preocupação em relação à manutenção da atividade e, consequentemente, dos empregos a ela relacionados, é grande.

Algumas atividades agropecuárias são realizadas no município. Segundo o IBGE (2007), existem estabelecimentos com lavouras temporárias, permanentes, pastagens e criação de aves. A estrutura empresarial, em 2006, apresentava apenas 10 unidades de Alojamento e Alimentação, que empregavam apenas 192 (cento e noventa e duas) pessoas assalariadas.

Iranduba está localizado entre os rios Negro e o Solimões. Como esses dois rios possuem características bastante distintas, o primeiro com águas escuras e formação de praias de areia branca na seca, e o outro com água barrenta, mas com mais variedade faunística, o município apresenta atrativos naturais diversificados (como Áreas de Preservação Ambiental, rios, muitos lagos, furos, paranás e igapós) passíveis de aproveitamento turístico durante todo o ano. Entretanto, não há investimentos para o desenvolvimento do turismo. Até pouco tempo, Iranduba não constava da lista de destinos turísticos disponível no portal

\footnotetext{
${ }^{86}$ Trecho retirado do portal da Biblioteca Virtual do Governo do Estado do Amazonas. Endereço: http://www.bv.am.gov.br/portal/conteudo/municipios/iranduba.php. Último acesso: nov./ 2011.
} 
oficial do Governo do Estado, apesar de concentrar em sua área grande parte dos hotéis de selva da região. Os hotéis e pousadas locais aproveitam-se do entorno, mas:

(...) não há uma divisão justa de benefícios. A agregação de valor da atividade é a mínima possível para as comunidades que vivem no entorno dos hotéis de selva:

- Não há fornecimento de alimentos por parte das comunidades, como: frutas e pequenos animais (frango, peixe, etc.), porque não existe incentivo para desenvolver uma agropecuária familiar. Os alimentos vêm de Manaus;

- As pessoas contratadas para trabalhar nos hotéis do lugar geralmente são da capital, porque possuem maior qualificação profissional, como curso de inglês, informática, entre outros;

- Não existe nenhum tipo de fundo financeiro levantado pelos hotéis para compensar o uso dos recursos naturais de Iranduba, ou para que as comunidades locais possam desenvolver alguma atividade econômica com o fim de suprir suas necessidades básicas (RIBEIRO et al., 2012: 21).

Apesar da proximidade de Manaus, o acesso ao município, até o final de 2011, era feito por meio de balsas, com travessia que durava cerca de meia hora. A espera nas longas filas para atravessar o rio Negro provocava entraves na economia local, dificultando e encarecendo a circulação de produtos e pessoas. Por outro lado, isso inibiu por anos a expansão urbana e uma possível favelização do município, como é comum a áreas de entorno de grandes metrópoles. A construção de uma ponte sobre o rio Negro (Ilustração III.14), que ficou pronta no final de 2011, facilitou essa travessia e tende a dinamizar a economia regional e provocar grandes mudanças na realidade do município. Observa-se, no entanto, que essas mudanças nem sempre serão satisfatórias em termos socioeconômicos, ambientais e culturais.

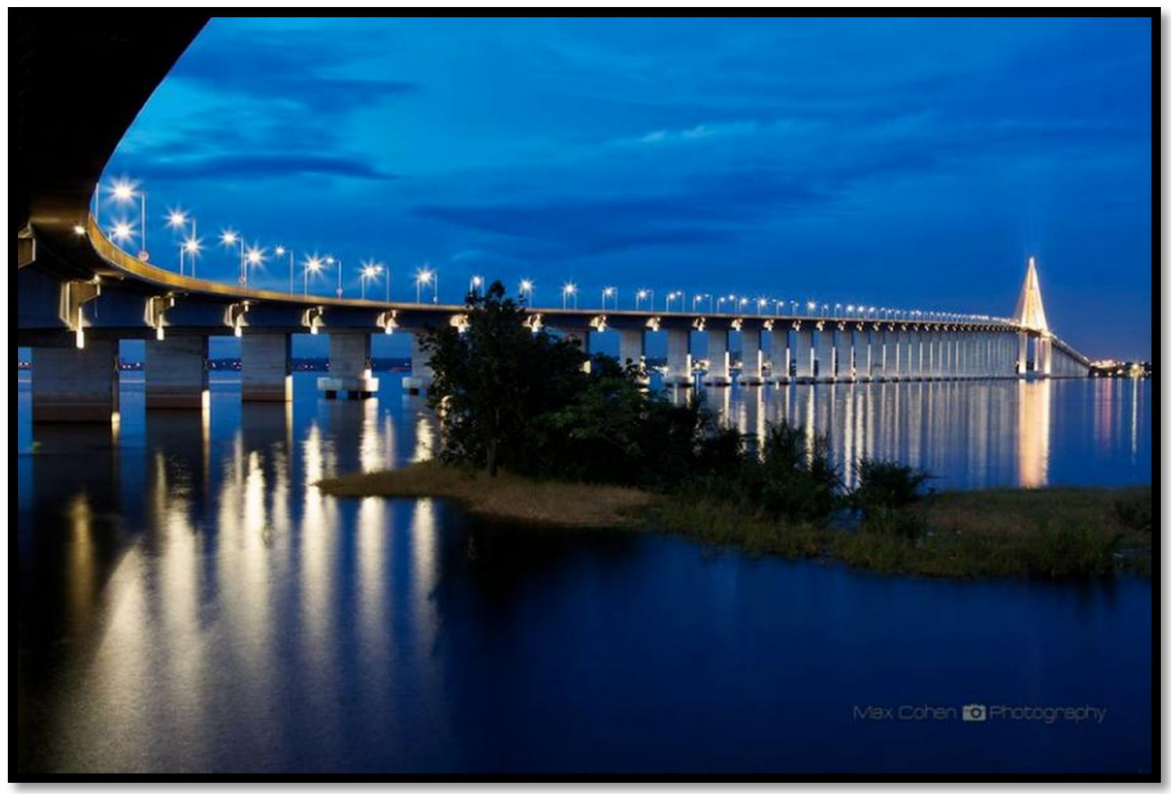

lustração III.14: Ponte sobre o rio Negro (FotografiA: Max Cohen). 
Os Estudos Prévios de Impacto Ambiental (EPIA), realizados para a execução dessa obra, indicavam que a estrutura produtiva de Iranduba centrava-se basicamente no ecoturismo, principalmente devido à presença de hotéis e pousadas instalados no município - Hotel Ariaú Amazon Towers, Hotel Lago Salvador Lodge, Acajatuba Jungle Lodge, Pousada do Francês e Pousada Amazônia (UFAM, 2007). O EPIA (Tomo 3, Cap. IV, partes C e D) destacava ainda a Cachoeira do Castanho, os Lagos do Limão, de Acajatuba, Ubim e Janauari e, também, o Parque Estadual do Rio Negro como atrativos locais. No entanto, o documento ressaltava que o Ecoturismo praticado nas comunidades analisadas está "diretamente relacionado aos empreendimentos hoteleiros da região. O acesso dos turistas às comunidades se dá por meio dos hotéis, em pacotes turísticos fechados, por meio de barcos próprios". Por isso, reforçava e recomendava "o aumento do número de áreas protegidas e o incentivo de projetos direcionados ao empreendimento turístico".

O RIMA do mesmo empreendimento (UFAM, 2007) salientava que "os benefícios serão inestimáveis para o segmento de turismo, uma das maiores fontes de divisas de vários países do mundo, desde que se apliquem metodologias sustentáveis para a sua exploração". Em Componente 3 - Variáveis (Impactos Possíveis) do Meio Social e Cultural, listava vários pontos ligados ao turismo ou arqueologia:

57. Novos pontos de atração turística.

(...)

60. Mudança no acesso e criação de novos espaços públicos para o lazer e turismo.

61. Patrimônio - mudança nas oportunidades de acesso aos locais históricos, santuários, sítios arqueológicos.

62. Mudança na incidência de depredação do patrimônio histórico/arqueológico.

63. Mudança na taxa de descoberta de novos sítios arqueológicos.

As principais conclusões (item C), relacionadas à fase de Operação (1 - 2 anos), recomendavam atentar ao oferecimento de condições impulsionantes para o setor oleiro e para o turismo da região; ao favorecimento de novas descobertas arqueológicas; ao acesso às atividades culturais municipais; à criação de novos espaços turísticos e de lazer no entorno da ponte. Dentre os impactos negativos, as principais observações também foram em relação ao turismo. O relatório chamava atenção para o fato de que, com a facilidade de acesso, poderia ocorrer saturação do turismo devido à grande quantidade de visitantes, ultrapassando o limite de carga da região. Isso resultaria em (UFAM, 2007):

- poluição dos igarapés, florestas e estradas, 
- especulação fundiária, (...)

- surgimento de bairros pobres (...)

- irritação da vida selvagem e dos habitantes locais,

- degradação da paisagem e recursos,

- perda da diversidade cultural - substituição dos modos de vida e valores tradicionais pelos valores dos visitantes; Mudanças nos padrões locais de consumo para se adequar aos padrões dos visitantes.

- acentuação da fragmentação cultural, que consiste na transformação das tradições - música, arte, comida, vestuário, arquitetura, relacionamentos etc. - para agradar os turistas e favorecer sua comercialização.

Do ponto de vista arqueológico, o município de Iranduba mostra-se bastante atraente, com cerca de 100 sítios arqueológicos localizados pelo PAC e alguns já pesquisados intensivamente. Os sítios encontram-se espalhados pelo município, em ambientes diversos, na margem do rio Solimões, nas praias do rio Negro e nas proximidades de lagos. Cerca de 20 desses sítios estão em areais possivelmente muito antigos, já que as cerâmicas estão ausentes, e são frequentes os materiais líticos lascados (COSTA, 2009).

No que se segue, alguns sítios arqueológicos e comunidades municipais serão brevemente descritos e ilustrados para demonstrar a variabilidade do patrimônio local, bem como para esclarecer a situação com a qual se conviveu ao se propor o aproveitamento dos sítios locais. Esta breve descrição pretende apenas esboçar o cenário municipal já que, embora diverso, o patrimônio arqueológico está, na maioria dos casos, associado à chamada Terra Preta, como em grande parte da Amazônia.

\section{Sítio Arqueológico hatahara.}

O sítio arqueológico Hatahara está localizado na periferia da sede do município de Iranduba, em uma propriedade particular. Esse sítio foi descoberto em 1997. A sua importância é atestada pelos resultados das escavações realizadas sob a coordenação do Prof. Dr. Eduardo Neves do MAE/ USP (1999, 2001, 2002, 2004, 2006, 2008 e 2009), as quais forneceram muitos dados e aqueceram o debate entre as principais correntes teóricas sobre a arqueologia amazônica. 
Hatahara é, cientificamente falando, o sítio arqueológico melhor conhecido na Amazônia central brasileira e, ainda assim, é imensa a possibilidade de extração de informações do registro ali preservado. No local, vários fatores despertam o interesse, como, por exemplo, a grande quantidade de fragmentos cerâmicos na superfície; a presença de Terra Preta; a posição geográfica do mesmo (Bluff Model); a presença de montículos construídos com terra e cerâmica; os sepultamentos com diferentes datações; a complexidade da estratigrafia; e a presença de vestígios de pelo menos quatro fases arqueológicas (Açutuba, Manacapuru, Paredão e Guarita).

Ilustração III.15: Sítio Hatahara (FOTOGRAFIA: Adriana Guimarães, 2006).

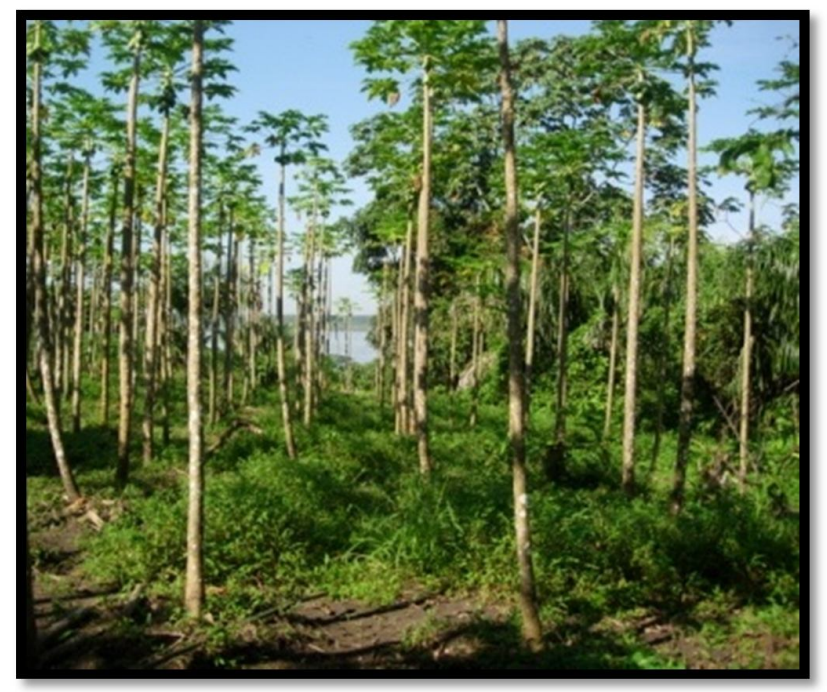

A correlação entre a presença desses distintos complexos cerâmicos e outras informações ligadas ao posicionamento dos mesmos, a suas profundidades, entre outras, sugere que a região central do sítio arqueológico pode ter sido intensamente reocupada, apontando para a importância dessa área e fazendo com que se avilte a possibilidade de populações numerosas e de formas de ocupação complexas (MACHAdo, 2005; NeVES E PETERSEN, 2006). A sua periferia, por outro lado, parece ter servido a ocupações distintas (MACHADO, 2005; Rebellato, 2007).

A extensa porção de Terra Preta fez com que a área fosse aproveitada para plantações de mamão, banana, limão e abacaxi (Ilustração III.15). Isso, em certa medida, ajudou a preservar o sítio, interferindo apenas nas camadas mais superficiais. Atualmente, o terreno onde se encontra o sítio Hatahara é propriedade da Indústria de Pisos da Amazônia (IPA), que construiu uma fábrica para produzir artigos em madeira certificada (pisos laminados) com foco no mercado internacional. A instalação da fábrica deu-se em uma área periférica à do sítio arqueológico, que permanece resguardado. 


\section{Sítio ARqueológico laguinho.}

O sítio Laguinho também se destaca no cenário local. Situado na calha do rio Solimões, está assentado em barranco bastante alto (cerca de 35 metros de altura em relação à várzea). Castro (2009), analisando dados obtidos em duas etapas de campo, 2006 e 2007, conclui que as grandes dimensões desse sítio o colocam "em segundo lugar quando comparado com outros sítios da Amazônia central, sendo Açutuba o maior deles e o Hatahara na terceira posição". Além disso, o autor sugere que esse sítio possa ter sido "um centro político ou cerimonial influente na região". Essa hipótese baseia-se na percepção de que os montículos possuem dimensões e morfologia que não são habituais em sítios similares. A análise regional também aponta a presença de outros sítios com Terra Preta com menor dimensão em sua proximidade, que sugerem uma predominância daquele sobre os demais.

Esse sítio é privilegiado em termos de cenário. De diversos pontos do sítio, a vista que se tem da paisagem do entorno é impactante. Hoje, a área do sítio é destinada a plantações comerciais, principalmente de mamão (Ilustração III.16).

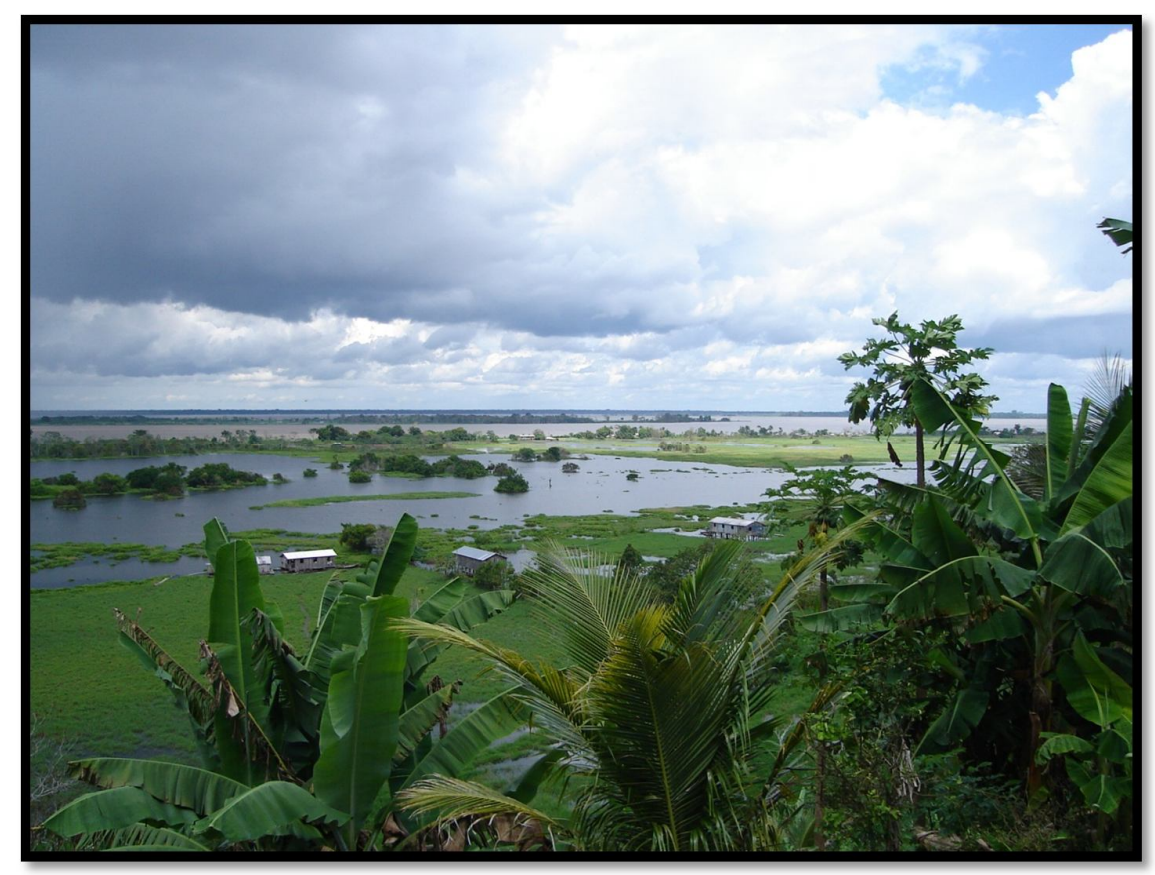

Ilustração III.16: Vista do sítio arqueológico Laguinho (FotogRAFIA: Acervo PAC, 2007). 


\section{Sítio ARqueológico Açutuba.}

O sítio arqueológico Açutuba localiza-se na altura do km 28 da estrada Manoel Urbano (AM 070) e estende-se por aproximadamente $3 \mathrm{~km}$ ao longo da margem direita do rio Negro, ocupando o topo e a vertente de um terraço elevado.

Identificado em 1994, foi alvo de pesquisas do PAC em diversas etapas (1995, 1997, 1999, 2002, 2004). Heckenberger e colegas (1999) sugerem que o sítio pode ter sido densamente povoado nas ocupações mais recentes da área. Lima (2008), em estudo posterior, teve dificuldades em avaliar "forma e padrão de assentamentos relacionados ao componente Açutuba" (LIMA, 2008: 69), embora tenha arriscado que nesses estratos mais antigos as aldeias, provavelmente, possuíam tamanho reduzido e não tenham alterado profundamente a paisagem. A pesquisadora, baseada nas datações encontradas, afirma que a "extensa área de três quilômetros da margem do rio Negro, onde se localiza Açutuba, foi ocupada em tempos pré-coloniais durante mais de dois mil anos" (LIMA, 2008: 77), com longos períodos de abandono (cerca de quinhentos anos) e posteriores assentamentos maiores e mais estáveis. Lima não propõe hipótese para o abandono total do sítio no século XIV (portanto, antes do contato com os europeus), mas acredita que isso não se relacione à escassez de recursos. A autora defende que a área tem grande importância para a compreensão da cronologia da Amazônia central e que as cerâmicas antigas ali encontradas podem representar "o início da ocupação de grupos ceramistas na região" (LIMA, 2008: 84).

Entre os meses de setembro e janeiro ${ }^{87}$, forma-se, nas proximidades do sítio arqueológico, uma praia de areias brancas, chamada Praia do Açutuba, que até pouco tempo era relativamente pouco visitada. Ultimamente, com a facilitação do acesso ao município, ela vem sendo anunciada por jornais locais como o "novo destino dos amazonenses"

\footnotetext{
87 Descrição de Iranduba no site Descobrindo o Amazonas. O El Dorado é aqui. Endereço: http://descobrindooamazonas2.webs.com/iranduba.htm. Acesso: fev./2012.

88 A Crítica.com Notícias. Açutuba: o novo destino dos amazonenses. Disponível em: http://acritica.uol.com.br/noticias/Manaus-Amazonas-Amazonia-Acutuba-destinodosAmazonenses 5 594590539.html. Acesso: fev./2012.
} 


\section{COMUNIDAde DE PARICATUBa.}

Paricatuba é uma das comunidades do município de Iranduba. Distante da sede do município, e mantida num certo isolamento, a comunidade convive com contradições. Além da história dolorida e das características singulares da própria vila e do entorno, Paricatuba convive com um turismo em escalas diversificadas: do turismo massificado aos finais de semana, nas praias do rio Negro, à visitação esporádica por parte de turistas estrangeiros, levados ao local por guia de hotéis da redondeza (Ilustração III.17).

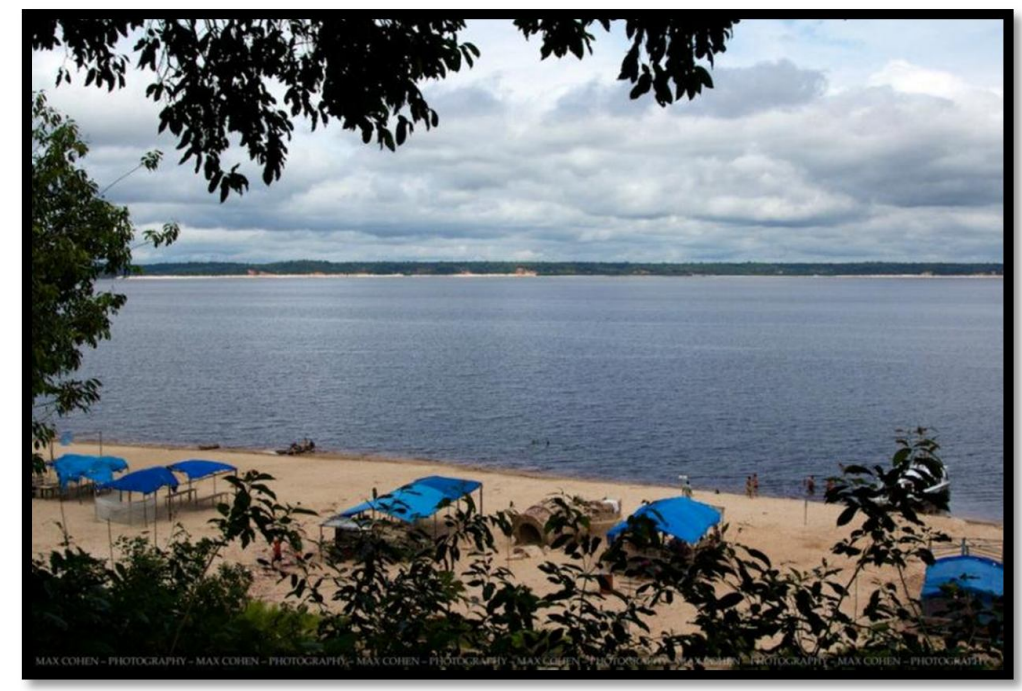

Ilustração III.17: Praia de Paricatuba (FotografiA: Max Cohen).

A comunidade possui em seu entorno áreas com vegetação bem preservada, uma cachoeira, grande diversidade faunística, com destaque para as muitas aves e regulares visitas de botos.

Segundo Neto (2005), Paricatuba estava ocupada por índios do tronco Mura, oriundos dos rios Madeira e Purus, quando três famílias se instalaram no local, no início da década de 90 do século XIX. A convivência entre eles teria sido pacífica.

Em junho de 2005, trabalhos arqueológicos foram realizados na comunidade, depois que a denuncia de uma moradora levou à paralização das obras para a implantação da rede de esgoto local, financiada com recursos públicos. Os trabalhos foram realizados aproveitando a linha de escavação já aberta pelas obras. Assim, a cada $25 \mathrm{~m}$ era evidenciado um perfil de 1m. Em áreas onde as obras não haviam começado, foram abertas unidades de $1 \mathrm{~m} \times 0,5 \mathrm{~m}$ 
com finalidade de resgate. "Estes trabalhos evidenciaram materiais cerâmicos e líticos relacionados às tradições Guarita, Manacapuru e Paredão, inclusive com a presença de estruturas semelhantes, embora mais discretas, às encontradas nos sítios com montículos" ${ }^{\prime 89}$.

No entanto, o principal atrativo da Vila é, sem dúvida, o grande prédio em ruínas, conhecido como 'as ruínas de Paricatuba'. O prédio possui uma beleza notável, além da grandiosidade que destoa do entorno (Ilustrações III.18, III.19 e III.20).

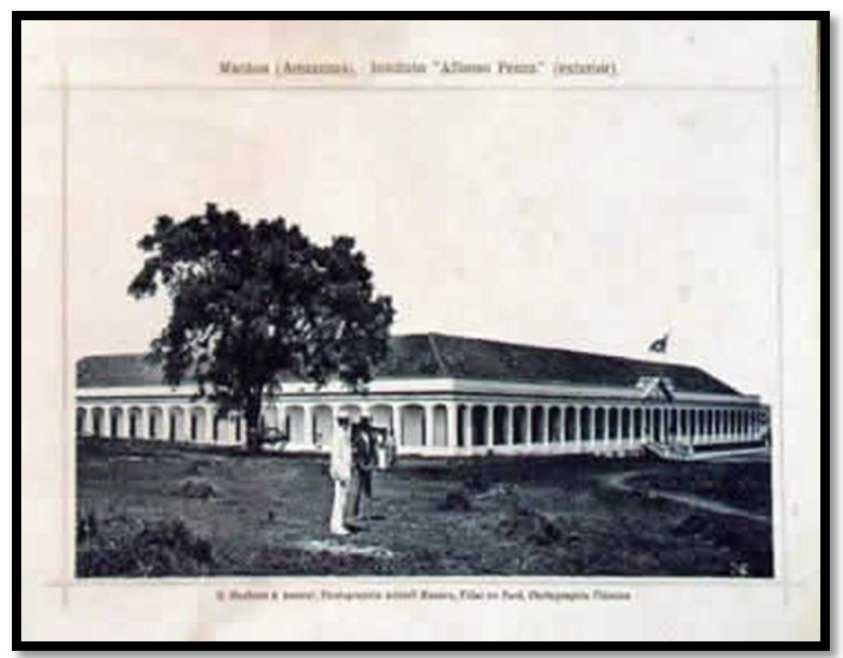

Ilustração III.18: Prédio de Paricatuba na época em que foi construído. (Fotografia digitalizada, cedida pelos professores da Fundação Bradesco. FontE: desconhecida).

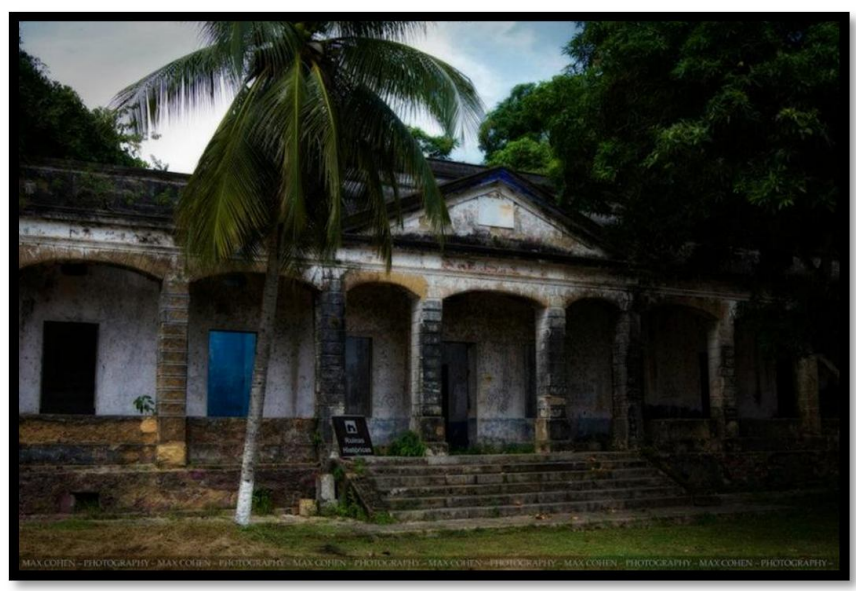

Ilustração III.19: Situação atual da fachada do prédio (FotografiA: Max Cohen).

\footnotetext{
${ }^{89}$ Informações retiradas do relatório parcial das etapas de levantamento e resgate arqueológico realizadas na comunidade de Paricatuba, Iranduba-AM. 09 a 29 de junho de 2005. NEVES et al., s/d. (não publicado).
} 

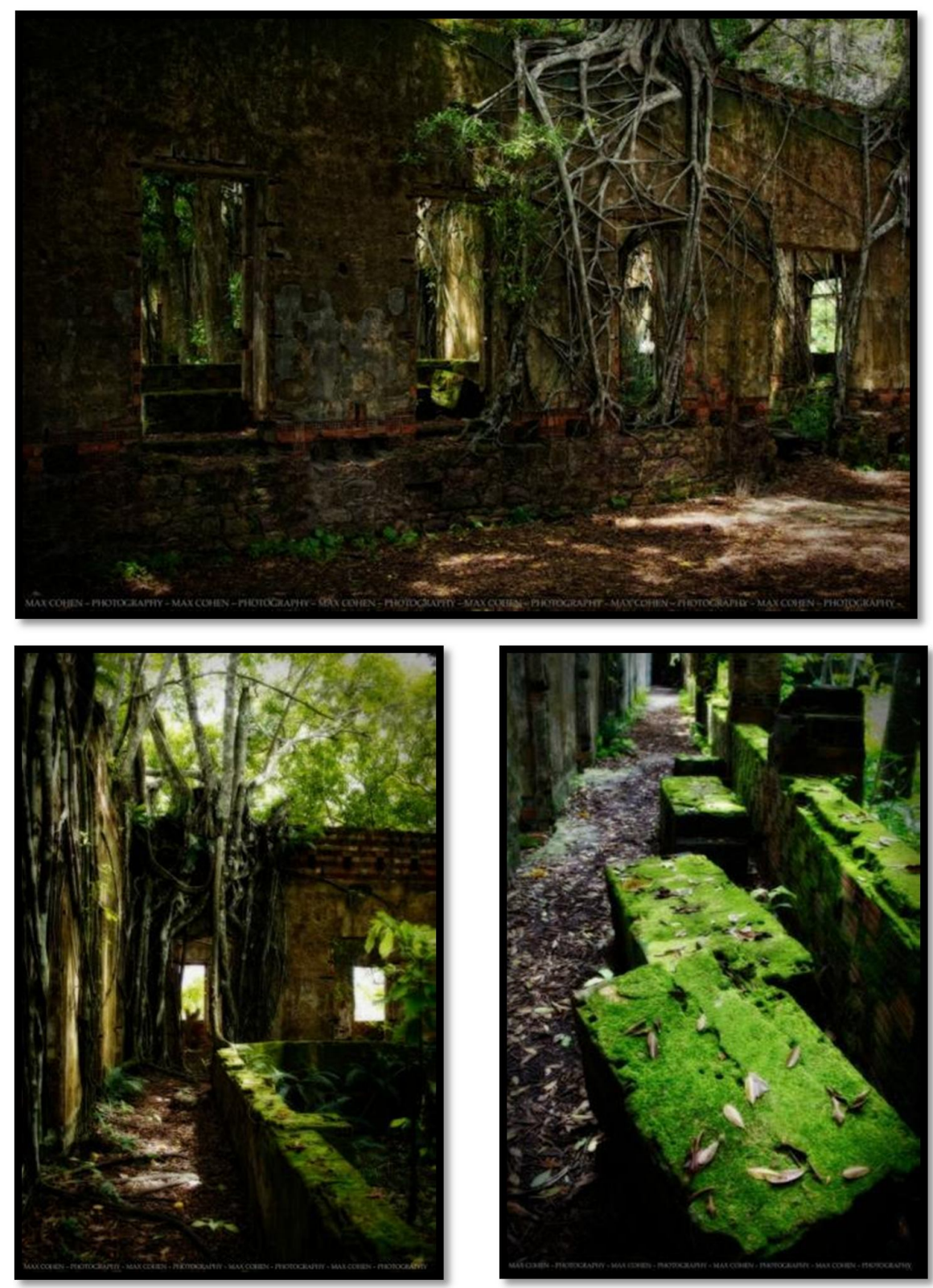

Ilustração III.20: Situação atual do interior do prédio (FotografIAS: Max Cohen).

Em 1898, o Governo do Estado do Amazonas começa a construir uma hospedaria para imigrantes italianos. A construção é interrompida em alguns momentos e, logo depois de ficar pronta, é abandonada. Dois anos depois, em 1900, o governador Constantino Nery disponibiliza o local para a instalação de um espaço educacional.

A única bibliografia acessada que descreve as características arquitetônicas dessa edificação foi o artigo, não publicado, O Patrimônio de Paricatuba: Memória e Espaço, escrito pelos 
alunos do curso de Arquitetura e Urbanismo do Centro Universitário Luterano de Manaus, em 2002 (DUARTE et al., 2002):

A edificação principal do Patrimônio Histórico de Paricatuba, hoje totalmente tomada pela vegetação, interna e externamente, é de uma imensidão e uma beleza extremamente relevantes.

Contendo uma enorme área, essa edificação possui formas que chegam a ser inviáveis para nosso contexto, levando-se em consideração o trabalho extenso e minucioso de sua construção. Nas alas internas, pode-se observar já a inexistência de portas, janelas, cobertura e reboco nas paredes. Mas ainda temos resquícios dos ladrilhos originais dos pisos.

Por ter passado por diversos usos, inclusive um mais recente (a escola), percebe-se a existência de uma descaracterização nos materiais originais de construção.

Em termos de elementos formais arquitetônicos, percebemos que tanto a edificação principal quanto as secundárias, possuem vergas em arco pleno nas portas e vãos. Na entrada principal do edifício central, percebemos a presença de uma cornija, cimalha (ou platibanda), tímpano, friso, arquitrave, pórtico e pilares em falsa cantaria (por toda a construção). Um fato interessante é que os vãos, mesmo tendo a forma retangular, possuem arcos em sua estrutura.

Essas formas caracterizam a construção como eclética, mesmo pelo período em que foi concebida. E as mesmas características estão presentes nas construções secundárias, que compõem as outras partes do Patrimônio (igreja, necrotério, dispensário).

É importante ressaltar que no local, ainda há restos da cerâmica, dos tijolos e outros elementos decorativos utilizados na decoração.

Tais informações apontam para a necessidade de trabalhos de arqueologia histórica aprofundados, que, certamente, seriam muito produtivos e acrescentariam muitas informações interessantes ao projeto de uso público.

Em 1905, o prédio passou por uma reforma e, no ano seguinte, foi inaugurado o Instituto Affonso Penna, uma escola agrícola e profissionalizante, administrada por padres espiritanos franceses (Ilustração III.21).

Segundo Pessoa (2010), o Instituto Affonso Penna ensinava diversos ofícios, como carpintaria, funilaria e sapataria, apenas para meninos. A pesquisadora conta que muitos desses menores eram de origem indígena e órfãos e passavam a morar em Paricatuba.

Os alunos pobres que se quizessem fazer lavradores de gado, industriais e artífices, alli encontrariam amparos e elementos para desenvolver as suas aptidões e mais tarde formaremse cidadãos úteis à pátria, e especialmente à indústria e à lavoura do estado, tão descuradas até agora. (...) Com o ensino elementar que alli se ministrava, habilitar-se-iam os rapazes a applicar, na prática, com intelligencia o que em theoria aproveitassem. Concomitantemente com a escola agrícola, virão os conhecimentos zootechinicos que habillitem a methodizar a industria dos gados, sem a qual não há exploração agrícola, que valha. E, quando as officinas do Instituto começarem a lançar os productos de suas industrias no mercado de Manáos, por certo que os productos congêneres extrangeiros e dos outros Estados não poderão competir com elle (Jornal do Comércio, 26 de junho de 1906 apud DUARTE et al., 2005). 

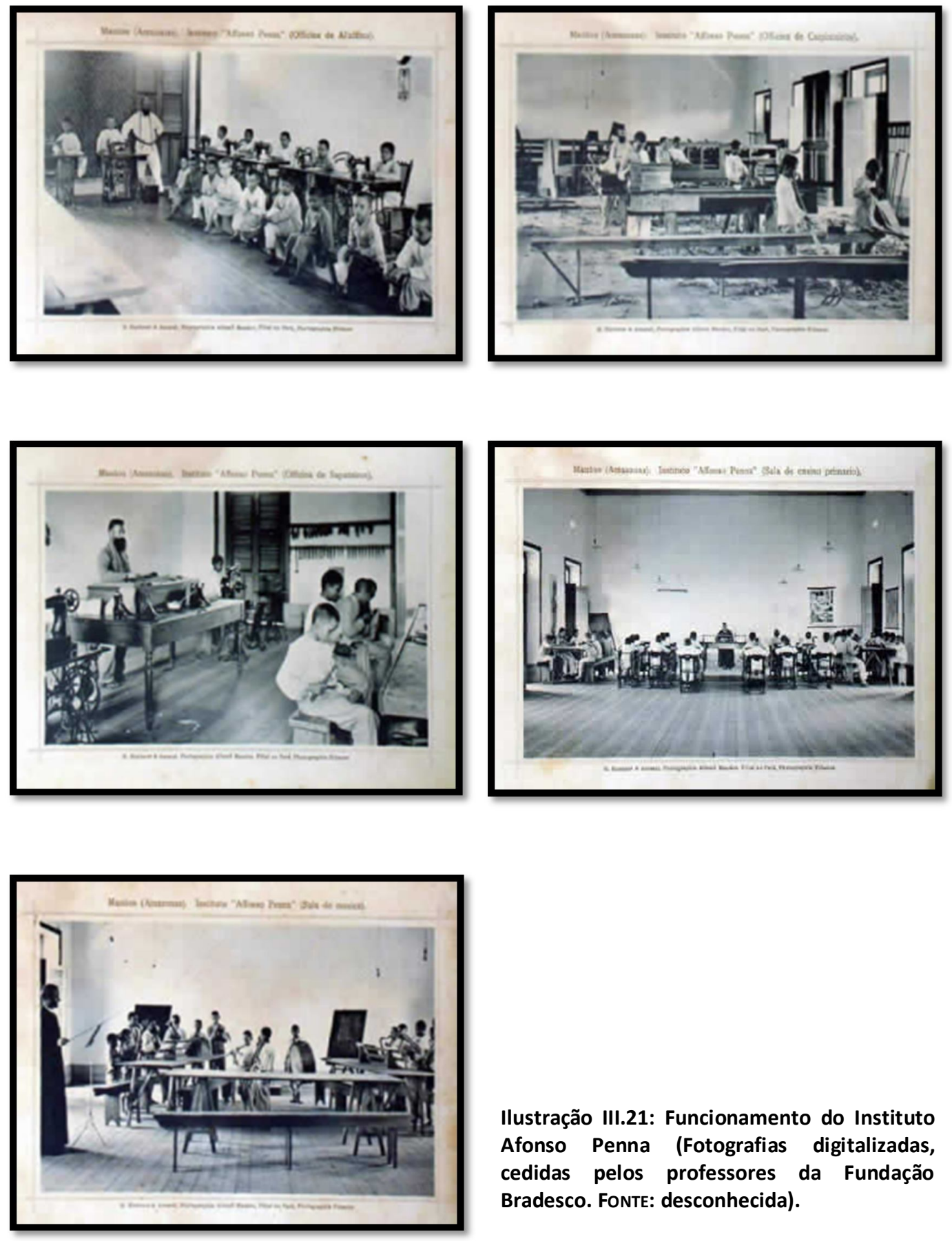

Ilustração III.21: Funcionamento do Instituto Afonso Penna (Fotografias digitalizadas, cedidas pelos professores da Fundação Bradesco. FonTE: desconhecida). 
Neto (2005) conta que, por volta de 1916, o Liceu interrompeu suas atividades pedagógicas e o casarão foi transformado em Casa de Detenção. O prédio teria sido, então, adaptado para receber os detentos, que ali permaneceram até o início da década de 20.

Em meados da década de 20, "havia uma pandemia de hanseníase" em vários estados brasileiros, com cerca de 800 doentes no estado do Amazonas (SANTOS et al., 2008). Segundo esses autores, embora o tratamento através do isolamento dos doentes nunca tenha sido unanimidade entre a classe médica, ele foi bastante utilizado por todo o país, principalmente desde o ano de 1920, quando o Regulamento Sanitário brasileiro foi criado. Tal regulamento, entre outras medidas, obrigava a submissão das pessoas a exames e ao isolamento, proibia a atuação profissional por parte dos doentes, proibia a amamentação natural pelas mulheres leprosas e ordenava a segregação imediata dos filhos nascidos de pais leprosos (SANTOS et al., 2008).

Nesse contexto, em julho 1924, o prédio de Paricatuba foi cedido, através do Dec. 1479, à Diretoria de Hygiene do Estado do Amazonas para a implantação da leprosaria, que ali funcionou por cerca de sessenta anos.

Embora nessa época ainda abrigasse alguns presos, o prédio estava em péssimo estado de conservação e precisou passar por uma grande reforma e adaptação. Ao que tudo indica, foi na época dessa reforma que foram construídos o dispensário, o necrotério, o serviço de bombeamento de água, a casa do administrador e a capela. Neto (2005) relata que:

Durante o período da remodelação do grande prédio e depois de reformado, Paricatuba recebeu inúmeras visitas de pessoas em passeio, autoridades, médicos, higienistas. A última foi feita pela embaixada japonesa, na pessoa de seu representante legal no Brasil, Schichita Tatsuké, em 1925, acompanhada pelo presidente do Estado, Ephigênio Sales, e várias autoridades, tendo sido filmados vários trechos do local pelo operador da empresa J. G. Araújo, Ltda., Silvino Santos. O vapor "Ayapuá", da flotilha mercante do Estado, que acolheu a comitiva, foi estruturado para receber ilustres visitantes, com um farto serviço de bordo de frios e gelados, e a música executada por uma afinada orquestra de pau e corda.

No entanto, a realidade dos doentes era outra. Os relatos encontrados sobre essa época confirmam o cenário de segregação e sofrimento imposto aos doentes e seus familiares.

No 7o Congresso Internacional de Leprologista, ocorrido em Tokyo, em 1958, a prática de isolamento foi considerada ultrapassada (ALVES E OLIVEIRA, 2011). Contudo, aparentemente, não foi essa nova abordagem que teria provocado o fechamento do Leprosário Belizário 
Penna, e sim o medo por contaminações em Manaus, por via aquática. Discussões sobre essa possibilidade haviam começado antes mesmo da implantação da leprosaria em Paricatuba. Estando Paricatuba à montante de Manaus, no rio Negro, temia-se que a água contaminada pudesse atingir a cidade de Manaus. À época, concluiu-se que tal situação não seria possível e a leprosaria foi implantada. Mesmo depois de tanto tempo de funcionamento, essa mesma argumentação teria sido decisiva para o encerramento das atividades do local. Isso pode explicar a forma tão drástica como esse fechamento ocorreu e o fato de os doentes terem sido transferidos para o Hospital Colônia Antônio Aleixo, onde continuaram a ser tratados (MONTEIRO, 2000). Moradores contam que houve uma intensa depredação do local, com venda dos materiais construtivos, corte de água, entre outros atos drásticos, e que essa destruição teria sido movida pelas próprias freiras franciscanas italianas, com o aval do então governador Arthur Reis.

Ressalta-se que este prédio é tombado como patrimônio histórico do Estado do Amazonas desde 1926 e, além disso, é "área de preservação ecológica do município" (Lei Orgânica da Câmara Municipal de Iranduba, Cap. VII. Parágrafo Único).

Após a destruição do prédio, cerca de 400 (quatrocentas) pessoas permaneceram no local e formaram a Comunidade de Paricatuba. Somente em 1992 foi aberto um ramal de terra fazendo a ligação da vila com a estrada.

Apesar dos seus atributos arquitetônicos e das proteções legais que o cerca, o prédio encontra-se em total abandono (Ilustração III.22). Pouco resta dos materiais de acabamento utilizados, como pisos, azulejos e metais. A estrutura está sendo abalada pelo crescimento de árvores que se apoiam e empurram as paredes do edifício. Muito lixo e entulho é depositado no interior do prédio, que se encontra praticamente inacessível. Algumas pilastras externas já tombaram sem a manutenção necessária. 

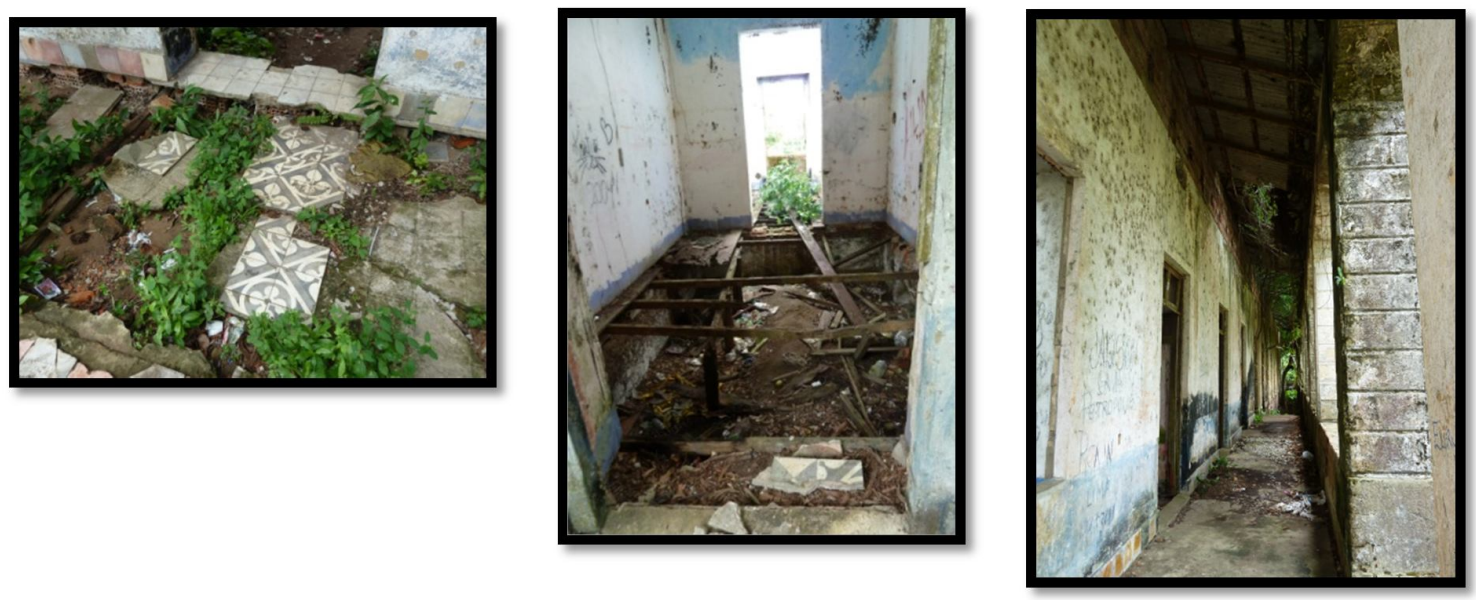

Ilustração III.22: Situação de abandono do interior da "Ruína de Paricatuba" (FotografiAs: Adriana Guimarães, 2011).

A ruína já foi foco de diversos projetos, dos quais merece destaque o desenvolvido pela Escola de Ensino Básico e Fundamental da Fundação Bradesco de Manaus. Este projeto, sob a orientação do professor Kleberson de Souza, alcançou reconhecimento nacional, através da sua participação no concurso Tesouros do Brasil ${ }^{90}$.

O Programa de Desenvolvimento Sustentável do Gasoduto Coari-Manaus desenvolveu projetos de melhorias da infra-estrutura em Paricatuba entre eles: a reforma da escola, a recuperação da iluminação pública, a perfuração do poço artesiano e construção do reservatório de 80 mil litros, a pavimentação do caminho que liga o porto às ruínas, a construção da casa de farinha, a construção do banheiro público com reator ecológico, inaugurado em 2006, para atender os visitantes e turistas. Esta construção localiza-se próxima à escada do porto e permanece a maior parte do tempo fechada e sem manutenção, só é aberta eventualmente quando os técnicos aparecem, não tem utilidade para os moradores tampouco para os visitantes. Além disso, muitos moradores receberam capacitação através de cursos promovidos pelo programa ou por outras entidades (SILVA, 2008: 57).

Em pesquisa sobre Percepções Sócio-espaciais e de Turismo em Paricatuba, Silva (2008) percebeu que os moradores locais têm apego ao lugar, valorizam os recursos naturais locais e entendem a necessidade da sua preservação, bem como demonstram reconhecer o valor do patrimônio cultural e arquitetônico da comunidade, principalmente vislumbrando-o como recurso turístico. No entanto, a autora conclui que a cadeia produtiva do turismo é

${ }^{90}$ Ver Revista Eletrônica Tesouros do Brasil (nov., 2005. Ano 2. $\mathrm{N}^{\circ}$. 06). 
excludente, pois não insere os moradores nos processos de planejamento e gestão, tornando a atividade insustentável a longo prazo.

No primeiro contato com a AMAZONASTUR, em 2007, o seu representante afirmou ter conseguido verba para construir uma pousada em Paricatuba, mas o dinheiro corria o risco de ser devolvido porque não foi possível conseguir um terreno na comunidade, devido às questões ligadas à propriedade dos mesmos. Também disse ter intencionado implantar um centro de informações turísticas em Paricatuba, mas, devido à problemática arqueológica (a localização da comunidade sobre um sítio), não conseguiu autorização para implantação do mesmo. Segundo ele, a iniciativa mudou, então, para a criação de centros de informação turísticas instalados em flutuantes. Ressaltou ainda o interesse em restaurar as ruínas, porém destacou as dificuldades relacionadas às autorizações do IPHAN e a necessidade de buscar parcerias para viabilizar esse trabalho.

Por conta da construção do gasoduto já citado, foi divulgado na mídia que a Petrobrás, em parceira com o Governo do Estado, promoveria diversas ações de beneficiamento comunitário $^{91}$. Entre as ações previstas, a serem coordenadas pela Secretaria de Desenvolvimento Sustentável (SDS), com a colaboração da Secretaria de C\&T (SECT), estariam o Levantamento Geométrico Estrutural e mapeamento de danos das ruínas do Casarão e o Projeto de Consolidação Estrutural das Ruínas do Casarão. Durante o período de elaboração desta tese, tentou-se, em diversas ocasiões, acessar qualquer material que mostrasse a realização desses trabalhos, mas os contatos nunca foram frutíferos. Assim, foram realizadas visitas esporádicas à comunidade no intuito de perceber alguma mudança no cenário. Lastimavelmente, as mudanças percebidas eram sempre para pior, encontrandose mais lixo e mais pilastras caídas.

Diante dessa realidade, destaca-se que ainda existem moradores na comunidade que foram tratados no leprosário e famílias que presenciaram toda a história de dor e sofrimento. Nesse sentido, é muito importante a realização de levantamentos da história oral dessas pessoas já que esta (Freire e Pereira, 2005):

[o]ferece uma reconstrução do passado não apenas mais próxima do real, como também mais justa. Ao gerar novas e histórias e novas interpretações, ela está contribuindo para o processo

${ }^{91}$ Fonte: JC e-mail 2804, de 05 de Julho de 2005. 
de dar voz a experiências vividas por indivíduos e grupos que foram excluídos ou marginalizados de narrativas históricas anteriores, ou seja, os esquecidos de sempre.

\section{Comunidade Lago do Limão.}

A comunidade Lago do Limão localiza-se distante do Porto Cacau Pireira cerca de 40 km e tem população estimada em mil habitantes, basicamente cabocla, proveniente, em muitos casos, de outras localidades do Amazonas, incluindo Manaus. A comunidade vive da agricultura de subsistência, do processamento da mandioca e da pesca. No lago, ainda é o possível observar a pesca com flechas, costume tradicional que permanece entre os moradores (MORAES, 2006).

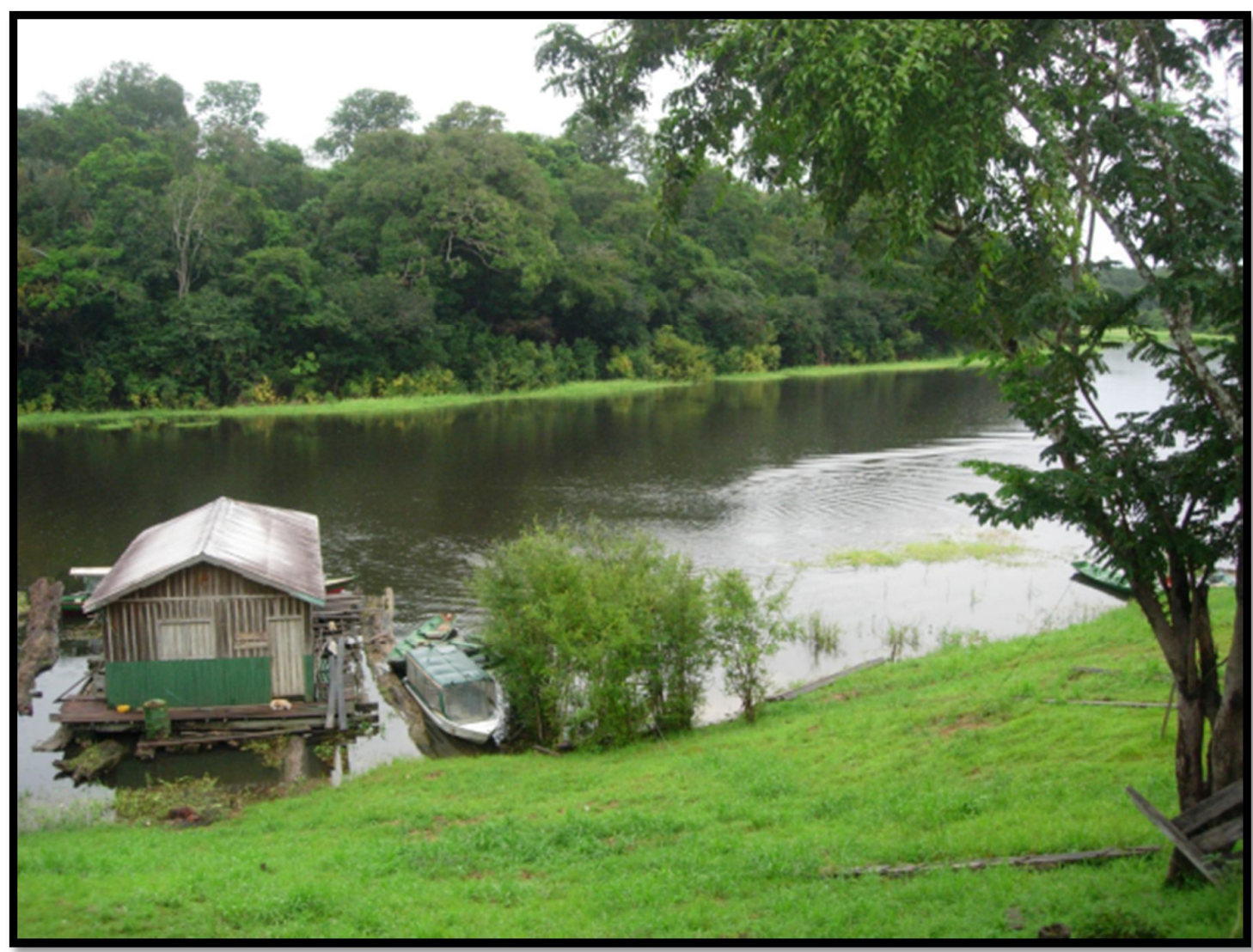

Ilustração III.23: Vista do Lago do Limão (FotografiA: Adriana Guimarães, 2010). 
No entorno do lago do Limão, o primeiro sítio escavado, o Osvaldo, trouxe contribuições importantes ao conhecimento arqueológico da região (PORTOCARRERO, 2007). Moraes (2006) identificou mais 15 sítios e analisou detalhadamente alguns deles. Os resultados dessas análises demonstraram que havia no local uma predominância de sítios da fase Paredão. Algumas particularidades intra-sítio foram percebidas, como a presença de montículos, estruturas habitacionais, contextos funerários e "currais de tartaruga". O autor sugere que os montículos encontrados em alguns sítios teriam sido utilizados como estruturas habitacionais e estariam dispostos em círculo, apontando para o formato das aldeias associadas à fase Paredão.

Essas, entre outras hipóteses levantadas a partir dos sítios pesquisados, demonstram a importância dos vestígios arqueológicos locais e a necessidade de sua preservação para que novas investigações científicas possam ocorrer futuramente. 


\section{CAPÍtulo IV - Propostas e Discussões.}

Dada a importância arqueológica de Iranduba no contexto da arqueologia amazônica, o município tornou-se referência regional para a ciência arqueológica brasileira. E, embora a falta de monumentalidade seja a tônica dos cerca de uma centena de sítios locais, julga-se coerente pensá-lo também como referência para o Turismo Arqueológico no estado do Amazonas.

Para isso, visando uma boa utilização do espaço municipal, e em conformidade com os objetivos dessa tese, foram pensadas propostas de uso sustentável do patrimônio arqueológico local, com o desenvolvimento de uma estrutura interpretativa dessa herança cultural, para o uso no turismo. Neste capítulo, são detalhados os encaminhamentos dados a cada uma delas e o processo para viabilizá-las. 
1. Tourism resources belong to the common heritage of mankind; the communities in whose territories they are situated have particular rights and obligations to them;

2. Tourism policies and activities should be conducted with respect for the artistic, archaeological and cultural heritage, which they should protect and pass on to future generations; particular care should be

devoted to preserving and upgrading monuments, shrines and museums as well as archaeological and historic sites which must be

widely open to tourist visits; encouragement should be given to public access to privately- owned cultural property and monuments, with respect for the rights of their owners, as well as to religious buildings, without prejudice to normal needs of worship;

3. Financial resources derived from visits to cultural sites and monuments should, at least in part, be used for the upkeep, safeguard, development and embellishment of this heritage;

4. Tourism activity should be planned in such a way as to allow traditional cultural products, crafts and folklore to survive and flourish, rather than causing them to degenerate and become standardized;

(GLOBAL CODE OF ETHICS FOR TOURISM - UNWTO) ${ }^{92}$

Atualmente, não é mais aceitável trabalhar o turismo sem ter em mente a sustentabilidade, ou seja, sem considerar o direito das futuras gerações de desfrutarem de destinos turísticos conservados, a satisfação das comunidades receptoras, a satisfação dos turistas, a proteção dos recursos ambientais e o respeito aos bens culturais (GUIMARÃES, 2003). Nesse sentido, a procura por modelos específicos para cada região e a integração de todos os envolvidos nos processos de decisão são pontos fundamentais.

\footnotetext{
92 TURISMO, UM USUFRUIDOR DO PATRIMÔNIO CULTURAL DA HUMANIDADE E CONTRIBUIDOR PARA O SEU APRIMORAMENTO. 1. Os recursos turísticos pertencem ao patrimônio comum de toda a humanidade; as comunidades em cujos territórios tais recursos se localizam têm direitos e obrigações específicos em relação a eles; 2. Políticas e atividades turísticas devem ser realizadas em relação de respeito para com o patrimônio artístico, arqueológico e cultural, devendo protegê-lo e transmiti-lo a gerações futuras. Deve-se atentar, em especial, para a preservação e renovação de monumentos, santuários e museus, bem como de sítios arqueológicos e históricos, cujo acesso aos turistas visitantes deve ser facilitado; deve-se incentivar o amplo acesso público a monumentos e bens culturais localizados em propriedades privadas, respeitando os direitos de seus proprietários, assim como o acesso a edificações religiosas, sem preconceitos em relação às necessidades comuns relativas a seus cultos; 3 . Os recursos financeiros captados com visitas a sítios e monumentos culturais devem ser, pelo menos em parte, destinados à preservação, à proteção, ao desenvolvimento e ao embelezamento deste patrimônio; 4. A atividade turística deve ser planejada de tal modo que permita que produtos culturais, artesanato e folclore sobrevivam e prosperem em vez de causar a sua degeneração e padronização (Código Mundial de Ética para o Turismo) [Tradução: Luciana M. Guimarães].
} 
O que aqui se expõe é uma etapa de um planejamento interpretativo dirigido ao município de Iranduba.

Tal etapa apresenta diversas possibilidades de aproveitamento turístico dos sítios arqueológicos locais, pautadas na arqueologia e visando o apreço e a proteção do patrimônio arqueológico local por e para as gerações atuais e futuras, fundamentadas na Interpretação Patrimonial. São quatro (04) propostas que demonstram como é possível interpretar um território bastante extenso e construir o sistema de redes descrito no Capítulo II. A decisão pela Interpretação Patrimonial já foi detalhada nesta tese, mas enfatiza-se que (NETHERY, s/d: 07):

[A]t its best, heritage interpretation provides a model of interaction between significant resources and the informed imagination. From such experiences people can take away not just greater knowledge about - and appreciation of - particular places or things, but also new insights into ways of reading the world around them, ways of discovering both instruction and delight in 'familiar' environments. When this occurs, they may also discover themselves to be not just 'consumers of heritage', but truly heirs to a wondrous legacy - with all the privileges and responsibilities that inheritance entails. And that is, in fact, the reality ${ }^{93}$.

O resultado alcançado contraria a descrença geral em relação à possibilidade de aproveitamento turístico dos sítios locais. Além disso, as propostas aqui apresentadas podem motivar um planejamento turístico consistente para o município, cumprindo o papel de encabeçar discussões participativas entre o poder público, a iniciativa privada e as comunidades locais, já que cada uma delas possui especificidades que provocarão distintos desdobramentos tanto em termos de financiamento e viabilização das mesmas, quanto para sua gestão e manutenção. Isto significa que estas propostas exigem, quase sempre, responsabilidade compartilhada entre todos os atores e essa característica é fundamental para conferir-lhes mais chances de continuidade.

Embora sejam simples e relativamente baratas, estas propostas foram pensadas de forma estratégica para exercerem alta atratividade sobre o mercado turístico, visando atingir a

\footnotetext{
93 Na melhor das hipóteses, a interpretação patrimonial fornece um modelo de interação entre os recursos significativos e a imaginação "informada". Destas experiências, as pessoas podem levar consigo não apenas um maior conhecimento sobre - e apreciação de - lugares e objetos específicos, como também podem obter novas perspectivas de interpretação do mundo ao seu redor, maneiras de descobrir tanto instrução quanto encanto em ambientes "familiares". Quando isto ocorre, as pessoas poderão descobrir-se não somente como "consumidores de patrimônio", mas também como verdadeiros herdeiros de um legado extraordinário - com todos os privilégios e responsabilidades que esta herança encerra. Esta é, de fato, a realidade [Tradução: Luciana M. Guimarães].
} 
demanda já existente na região (os ecoturistas), estendendo a sua permanência e estimulando gastos nas comunidades municipais.

Acredita-se que a estrutura de pensamento adotada para a elaboração destas propostas, fundamentada em tudo que foi exposto no decorrer deste trabalho, pode servir de exemplo para o aproveitamento turístico do patrimônio arqueológico de outras regiões brasileiras.

\section{1. Propostas para o Aproveitamento Turístico do Patrimônio Arqueológico de} IRANDUBA.

Foram selecionados três locais distintos para serem trabalhados: (1ㅇ․) o sítio arqueológico Hatahara, localizado na sede municipal e dentro de uma propriedade particular, por sua importância científica; (2‥) a comunidade de Paricatuba, devido à existência de sítios arqueológicos pré-históricos e de um sítio histórico em ruína, de propriedade pública, necessitando de investimentos urgentes em sua conservação; e (3‥) o Lago do Limão, onde pesquisas arqueológicas já haviam ocorrido e a comunidade viu-se frustrada em relação à construção do CABA. Uma quarta proposta foi testada (Turismo Científico), mas não está direcionada a nenhum espaço específico, mas sim condicionada à existência de escavações arqueológicas (Ilustração IV.1).

Cada uma das propostas encontra-se em um nível distinto de encaminhamento, já que nem sempre foi possível proceder às etapas seguintes - i.e. elaborar anteprojetos, projetos executivos ou implantá-las - embora muito esforço tenha sido empreendido para tal. Nesse sentido, é válido expor que o início deste trabalho aconteceu num cenário favorável, com aparente interesse do poder público municipal e estadual no desenvolvimento de projetos

de Turismo Arqueológico. Porém, ao longo dos cinco anos disponíveis para a sua realização, diversos problemas surgiram e dificultaram a negociação dessas propostas tanto com o poder público municipal e estadual, quanto com o IPHAN regional e, inclusive, com uma das 
comunidades trabalhadas. Nenhum desses problemas relaciona-se diretamente a esta pesquisa, estando, em parte, ligados às negociações do CABA (cf. cap. anterior) e, em outra, à atuações de membros do PAC em projetos de arqueologia de contrato. Estes problemas serão pontuados quando necessário, mas não serão detalhados. Todavia, analisa-se que essas interferências externas foram fatores impactantes no encaminhamento das propostas.

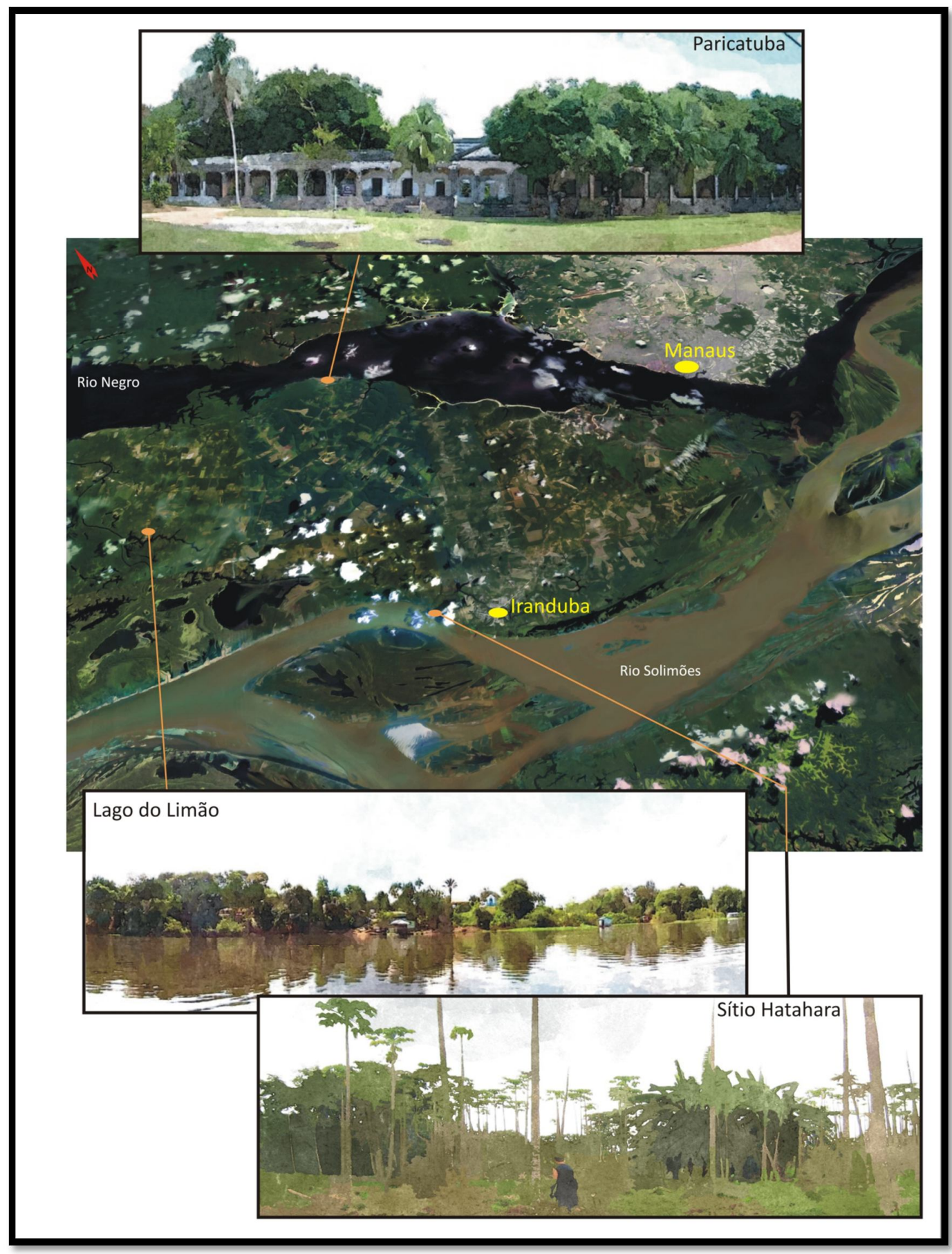

llustração IV.1: Localização e cenário atual dos locais trabalhados. ARTE: Gustavo Accacio. 
Como ajudar o município de Iranduba a se reposicionar no cenário amazônico, de um município recente, nascido devido à expansão de Manaus, e sempre à margem deste, para um local com uma grande relevância no cenário regional? Esta foi a questão norteadora para proceder a Interpretação Patrimonial do cenário arqueológico local. Entende-se aqui que a arqueologia presta esse auxílio na medida em que apresenta os resultados de suas pesquisas e, a partir destes, enfatiza o passado pujante do território hoje municipalizado. Dessa forma, concebe-se que a arqueologia permite, metaforicamente, reapresentar cenas de uma história que é importante não apenas para os munícipes, mas, também, para os amazonenses e para os brasileiros, de uma maneira geral. Foram escolhidos, assim, os seguintes tema, subtemas, formatos e abordagens a serem trabalhados:

\section{A arqueologia em Iranduba: reapresentando cenas da nossa história.}

- Uma Floresta Tocada.

○ Como? Musealização do sítio arqueológico Hatahara.

- Abordagens: ambiente, vestígios (solo antropizado, esqueletos, cerâmicas etc.), pesquisas arqueológicas, teorias e hipóteses para a Amazônia central.

- (Des)continuidades: o mesmo espaço, diferentes histórias.

○ Como? Interpretação da Vila de Paricatuba.

- Abordagens: primeiras ocupações, uma construção e muitas memórias, descaso com o patrimônio histórico e com a comunidade atual. 
- Inspiração e Lembranças.

- Como? Criação do Centro de Artesanato e Réplicas voltado à temática arqueológica no Lago do Limão.

- Abordagens: souvenirs e réplicas - arqueologia como inspiração pra uma comunidade, como lembrança para os visitantes e como material didático para muitos estudantes.

- A construção de um conhecimento.

○ Como? Turismo Científico

- Abordagens: aproximação do público com as pesquisas arqueológicas e explicação sobre a geração do conhecimento científico em arqueologia.

Pretende-se que cada uma das propostas possa ser transformada em um produto turístico, para que seja inserida no mercado turístico (DIAS E AGUIAR, 2001; BARRETo, 2002). Assim, cada um desses produtos poderia ser consumido separadamente, em visita única, ou em conjunto, em um roteiro mais extenso. Observa-se, contudo, que, mesmo individualmente, todas as propostas possuem alto poder de multiplicação dos benefícios econômicos para as comunidades em que se localizam. A multiplicação dos benefícios tende a atingir, inclusive, o turismo manauara, principalmente pelo aumento no tempo de permanência e nos gastos dos turistas, devido à disponibilização de novos atrativos no mercado turístico regional. 
IV. 2. EnCAMINHAMENTO das PROPOSTAS.

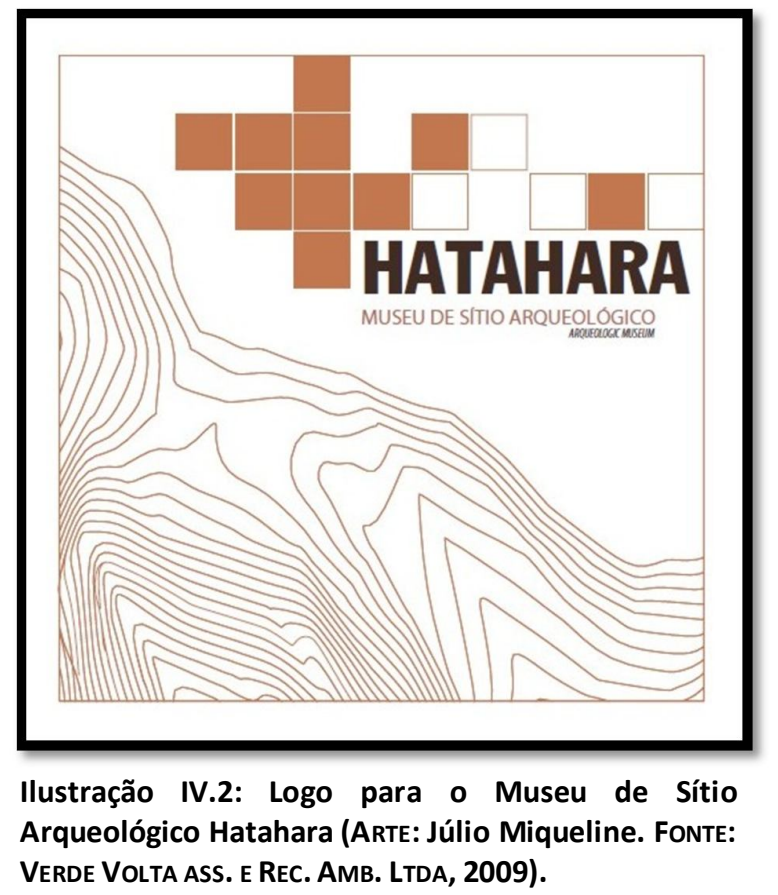

IV.2.1. Uma Floresta Tocada - Musealização do Sítio ARqueológico Hatahara.

Um pensamento comum em relação à Floresta Amazônica é a de um ambiente com muitas áreas intocadas pelo homem, uma floresta "virgem", na qual a presença humana seria devastadora. A escolha do tema Uma floresta tocada objetiva, portanto, provocar reflexão sobre essa ideia através da apresentação dos resultados de pesquisas arqueológicas, que demonstram a presença e a adaptação humana nesse ambiente há milhares de anos. A forma pensada para promover essa reflexão foi a criação de um museu de sítio, onde a experiência do visitante se centraria na pesquisa arqueológica, no ambiente e em experiências sensoriais.

Segundo Shanks e Tilley (1987), a "musealização é a elaboração de um sistema estético para criar significados". Um sítio musealizado interessa à sociedade como um todo. Um equipamento desse tipo tem uma função de divulgação científica importantíssima porque 
permite a divulgação dos resultados de pesquisas acadêmicas a uma ampla parcela da população (público escolar, comunidade local, regional e turistas nacionais) e, inclusive, possibilita a divulgação do patrimônio nacional a turistas estrangeiros.

Conforme Bruno (1996: 67-68), a musealização é "o processo constituído por um conjunto de fatores e diversos procedimentos que possibilitam que parcelas do patrimônio cultural se transformem em herança, na medida em que são alvo de preservação e comunicação".

O processo de musealização de um sítio arqueológico, no entanto, necessita de somas elevadas para concretizar-se. Somas estas que, normalmente, não estão disponíveis no âmbito de uma tese de doutorado. Deste modo, muitas reuniões foram realizadas no estado do Amazonas com diversos atores locais, num esforço de apresentação dessa ideia, bem como das outras ideias que compõem essa tese, buscando financiá-las. Uma dessas reuniões, na 1a Superintendência Regional do IPHAN, em Manaus, em julho de 2008, rendeu frutos. Na ocasião, o Sr. André Bazanella, então superintendente daquela regional, mostrouse interessado nas relações do turismo com a arqueologia na região e disposto a apoiar iniciativas nesse sentido, porém, duvidoso da real possibilidade de tornar um sítio cerâmico, aparentemente sem atrativo para visitação pública, em algo viável em termos financeiros, atrativos e educacionais. De todo modo, a reunião foi frutífera e, passado algum tempo, a 1a Superintendência Regional do IPHAN abriu uma licitação para a elaboração de um Anteprojeto para a Musealização do Sítio Arqueológico Hatahara.

Como forma de encaminhar essa proposta no âmbito desta tese, a VERDE VolTA ASSESSORIA E RECUPERAÇÃo AmBientAl LTDA., empresa da qual esta autora é sócia, disputou e venceu a licitação em questão. É o encaminhamento desse trabalho e os seus resultados que são aqui apresentados.

A EQUIPE

Para compor uma equipe, o edital exigiu a participação de "um arquiteto, um museólogo, um educador e um arqueólogo (com experiência comprovada em pesquisas relativas ao sítio em questão)” (Projeto Básico № 23/2008). Dessa forma, compuseram a equipe: 
- Anne Rapp Py-Daniel, arqueóloga;

- Carla Gibertoni Carneiro, educadora;

- Maria Cristina Oliveira Bruno, museóloga;

- Vasco Caldeira da Silva, arquiteto;

- Adriana Meinking Guimarães, turismóloga, como coordenadora.

A equipe montada compunha-se não apenas de um arqueólogo com experiência no sítio em questão, como previa o edital. Tanto a arqueóloga, quanto a turismóloga e a educadora já haviam participado de escavações no Hatahara, enquanto membros do PAC. A museóloga, por sua vez, também possuía ampla ligação com a temática arqueológica, fazendo parte do corpo docente do MAE/USP. A escolha do arquiteto também não foi aleatória. O profissional envolvido possui ampla experiência em exposições para grandes públicos, contrabalançando uma possível visão cientificista do projeto.

Deve-se chamar a atenção para o fato de que o envolvimento de uma profissional do turismo no projeto só aconteceu por esta ter interesse pessoal no desenvolvimento da proposta e, principalmente, por ser sócia-diretora da VERDE VOLTA, podendo, assim, atuar como coordenadora dos trabalhos. Não fosse essa a situação, dificilmente um turismólogo estaria envolvido num projeto de musealização de um sítio arqueológico, já que não é comum essa exigência em editais desse tipo, contrariando as indicações sobre a formação de equipes interdisciplinares no planejamento do Turismo Arqueológico.

Pode-se argumentar que um projeto de musealização não seja exatamente um projeto de Turismo Arqueológico. A esse respeito, deve-se relembrar que, de acordo com o estatuto do International Council of Museum (ICOM) ${ }^{94}$, adotado desde 2007:

$[A]$ museum is a non-profit, permanent institution in the service of society and its development, open to the public, which acquires, conserves, researches, communicates and exhibits the tangible and intangible heritage of humanity and its environment for the purposes of education, study and enjoyment (ênfase desta autora) ${ }^{95}$.

94 Fonte: Definição de Museu Segundo o International Council of Museum (ICOM). Disponível em: http://icom.museum/who-we-are/the-vision/museum-definition.html. Último acesso: mai./ 2012.

${ }_{95}$ Um museu é uma instituição permanente, sem fins lucrativos, em serviço da sociedade e de seu desenvolvimento, aberto ao público, que adquire, conserva, pesquisa, comunica e exibe o patrimônio material e imaterial da humanidade, e o seu ambiente, com propósitos educativos, de pesquisa e de entretenimento [Tradução: Luciana M. Guimarães]. 
Dessa forma, no debate sobre a relação dos museus com o turismo, concorda-se com Castro (2007) que afirma que, embora os museus e centros culturais sejam estimulados a desenvolver uma abordagem interdisciplinar em suas atividades, "os dois setores ainda operam em planos paralelos, mantendo uma parceria difícil, com pouco diálogo". Entretanto, como essa autora conclui, todos os envolvidos beneficiam-se com o avanço dessas discussões, já que tanto a Museologia quanto o Turismo Cultural visam o princípio constitucional do direito à educação, à cultura e ao lazer.

Ao longo do trabalho, outros profissionais envolveram-se no projeto, como o professor Eduardo Neves (coordenador do PAC e orientador das pesquisas no Hatahara), Júlio Miqueline, responsável pela formatação da comunicação visual, além de estagiários que ajudaram no projeto arquitetônico.

No caso do Anteprojeto de Musealização do Sítio Arqueológico Hatahara, o envolvimento de todos estes profissionais, desde o início dos trabalhos, foi fundamental para solucionar a grande questão que se apresentava: a "invisibilidade" do patrimônio a ser musealizado. Arrisca-se dizer que a presença de um profissional do turismo tenha sido representativa no sentido de planejar um museu de sítio capaz de integrar-se aos demais atrativos turísticos do estado do Amazonas, objetivando, desde o início, oferecer ao público em geral um ambiente estimulante, com a disposição de uma infraestrutura interpretativa capaz de aproximar a todos do patrimônio arqueológico local.

As longas discussões sobre a musealização do local demonstraram a dificuldade de se trabalhar com disciplinas diversas. O Anteprojeto de Musealização do Sítio Hatahara mostrou, por sua vez, que a interdisciplinaridade, por mais difícil de ser posta em prática, é uma oportunidade para alinhar pensamentos que não pode ser desperdiçada.

Um ponto importante em relação ao perfil do Anteprojeto de Musealização do Sítio Arqueológico Hatahara foi a inserção do mesmo dentro do sistema interpretativo local, conforme defendido nessa tese. Todavia, a conjuntura na época sugestionava que a musealização do sítio arqueológico Hatahara poderia ser a única, entre todas as propostas, a ser implantada, com poucas perspectivas em relação às outras (i.e. Centro de Artesanato Lago do Limão e Paricatuba). Dessa forma, arriscar-se-ia conceber essa musealização dentro de um sistema interpretativo que pudesse nunca existir de fato. Tendo isso em mente, a 
equipe decidiu pensá-la isoladamente, mas com possibilidade de integração a outras iniciativas que pudessem ocorrer no futuro, bem como viabilizando a sua utilização por parte do curso de Tecnologia em Arqueologia (UEA), o qual já estava em andamento naquele momento. Essa escolha traduz-se na abordagem bastante ampla pela qual optou-se no Roteiro de Comunicação (TABELA IV.1). Seguindo o mesmo raciocínio, a trilha exploratória sugerida foi pensada de modo que, no caso de novas escavações, rapidamente fosse possível integrá-las à proposta do museu, ou seja, de modo a se permitir 'musealizações relâmpago'.

\section{O Produto Final - Anteprojeto de Musealização do Sítio ArqueolóGico Hatahara}

O anteprojeto é, antes de mais nada, um estudo de viabilidade, ou seja, ele é o grande momento de concepção criadora, mas também de comprovação da propriedade (no sentido de ser apropriado) do conceito gerador delineado, de demonstração da aplicabilidade, funcionalidade e viabilidade de execução e implantação do museu e principalmente de instauração ou não de uma aura de confiabilidade no plano de sustentabilidade futura da instituição a ser implantada (FrANCO, 2005).

O 'produto final' do Anteprojeto de Musealização do Sítio Arqueológico Hatahara entregue ao IPHAN é composto por três cadernos, a saber:

- Caderno 01. Produto Final. Caderno principal, no qual é feita a descrição do projeto, seus objetivos e sua problemática, a justificativa da proposta e os estudos preliminares realizados - área (Ilustração IV.3), descrição do museu, roteiro de comunicação, síntese de conteúdo, atividades complementares e serviços a serem prestados, e recomendações sobre a estrutura organizacional;

- Caderno 02. Arquitetura. Onde se encontram croquis dos prédios e trilhas, a partir dos módulos estabelecidos no Roteiro de Comunicação e nas etapas de visitação (Ilustrações IV.4, IV.5, IV.6 e IV.7);

- Caderno 03. Programação Visual, no qual detalha-se a aplicação da linguagem visual nos painéis, no folheto informativo, no guia da Trilha Exploratória e no site (Ilustrações IV.8 e IV.9). 
TABELA IV.1:

Roteiro de Comunicação para o

Museu de Sítio Arqueológico Hatahara

\section{MóDULO I - INTRODUÇÃO/ APROXIMAÇÃO TEMÁTICA}

\section{Caminho entre o estacionamento e o Centro de Acolhimento.}

Objetivo Comunicacional: sensibilização do visitante em relação à natureza.

Campo Temático (eixo/abordagem, Elementos de conteúdo e Recurso comunicacional (linguagem de apoio):

I. Paisagem:

I.1. As características atuais da paisagem e os indícios de sua transformação pela ação do homem.

I.1.a. Fruição da paisagem de uma floresta reconstituída ao longo do caminho entre o estacionamento e o centro de acolhimento. Inserção de painéis com ilustrações de florestas em distintas situações (floresta preservada, manejada, devastada etc.);

I.1.b. Sinalização com elementos de instigação da curiosidade (perguntas).

Módulo II - ACOLHIMENTO TEMÁtICO GERAL

\section{Exposição A no Centro de Acolhimento}

Objetivo Comunicacional: introdução do visitante às perspectivas de visitação do sítio arqueológico Hatahara.

Campo Temático (eixo/abordagem) e Elementos de conteúdo:

II. A especificidade geográfica, histórica e arqueológica do sítio Hatahara:

II.1. O sítio Hatahara.

III. Homem e Natureza:

III.1. As dimensões e os limites da floresta;

III.2. As características dos rios da Amazônia;

III.3. Os ciclos da vida ribeirinha;

III.4. A diversidade da flora local;

III.5. A estratificação da fauna local na floresta densa/floresta aberta e nos rios de água preta/rios de água branca;

III.6. A ecologia amazônica e o conceito de floresta tocada.

IV. Historicidade da ocupação humana:

IV.1. As hipóteses sobre a ocupação humana da Amazônia;

IV.2. Os meios de subsistência das populações pré-históricas na Amazônia;

IV.3. A cronologia da ocupação da Amazônia. 
V. Arqueologia:

V.1. O Conceito de arqueologia;

V.2. Os Objetos da arqueologia;

V.3. O processo de trabalho do arqueólogo;

V.4. A Tipologia dos sítios arqueológicos;

V.5. Os principais sítios arqueológicos já pesquisados na Amazônia;

V.6. O Projeto Amazônia Central;

V.7. A Bibliografia geral sobre os temas tratados.

VI. Preservação:

VI.1. A cultura e a política de preservação do patrimônio cultural no Brasil.

Recurso comunicacional (linguagem de apoio): articulação expográfica entre diferentes tipos de informações e mídias - textos, info-gráficos, imagens, maquetes e artefatos.

\section{Módulo III - IMERSÃo NA TEMÁtICA do SítIO ARQUEOLÓGICO / DisPERSÃo TEMÁtICA PELAS TRILHAS.}

\section{Ponto 1.}

Objetivo Comunicacional: desdobramentos relativos ao enfoque temático central, a partir da imersão no universo da pesquisa arqueológica e da fruição do sítio arqueológico e da paisagem.

Campo Temático (eixo/abordagem), Elementos de conteúdo e Recurso Comunicacional:

VII.Rio:

VII.1. A localização do sítio Hatahara:

VII.1.a. Fruição da paisagem ribeirinha a partir de um mirante no topo de um morrote.

VII.2. Recursos aquáticos.

VII.2.a. Articulação expográfica entre texto, imagens e modelagens em autorelevo das espécies animais.

\section{Ponto 2.}

Objetivo Comunicacional: desdobramentos relativos ao enfoque temático central a partir da imersão no universo da pesquisa arqueológica e da expansão da fruição do sítio arqueológico e da paisagem.

Campo Temático (eixo/abordagem), Elementos de conteúdo e Recurso Comunicacional: 
VIII. Recursos Naturais:

VIII.1. Materiais utilizados na fabricação da habitação, dos artefatos, indumentárias e adornos.

VIII.1.a. Articulação expográfica entre texto, ilustração e artefatos.

VIII.2. Produtos utilizados na alimentação.

VIII.2.a. Fruição de áreas cultivadas;

VIII.2.b. Articulação expográfica entre textos e ilustrações.

\section{Ponto 3.}

Objetivo Comunicacional: desdobramentos relativos ao enfoque temático central a partir da imersão no universo da pesquisa arqueológica e da expansão da fruição do sítio arqueológico e da paisagem.

Campo Temático (eixo/abordagem), Elementos de conteúdo e Recurso Comunicacional:

IX. Terra Preta:

IX.1. Formação e características do solo antropizado denominado Terra Preta.

IX.1.a. Articulação expográfica entre texto e expositores amostrais de materiais naturais em processamento.

\section{Ponto 4.}

Objetivo Comunicacional: desdobramentos relativos ao enfoque temático central a partir da imersão no universo da pesquisa arqueológica e da expansão da fruição do sítio arqueológico e da paisagem.

Campo Temático (eixo/abordagem), Elementos de conteúdo e Recurso Comunicacional:

\section{Cerâmica:}

X.1. Abundância e características técnicas e artísticas da manufatura cerâmica local.

X.1.a. Fruição de uma zona de "chão de cacos";

X.1.b. Articulação expográfica entre texto, ilustrações e artefatos;

X.1.c. Articulação expográfica entre modelo em escala natural e legendas.

XI. Trabalho de campo:

XI.1. Como o arqueólogo trabalha em campo.

XI.1.a. Articulação expográfica entre texto, ilustrações, artefatos; 


\section{Ponto 5.}

Objetivo Comunicacional: desdobramentos relativos ao enfoque temático central a partir da imersão no universo da pesquisa arqueológica e da expansão da fruição do sítio arqueológico e da paisagem.

Campo Temático (eixo/abordagem), Elementos de conteúdo e Recurso Comunicacional:

XII. Conservação de material orgânico: o caso dos sepultamentos.

XII.1. Excepcional conservação e variedade de padrões de sepultamentos observados no sítio Hatahara.

XII.1.a. Articulação expográfica entre texto e ilustrações;

XII.1.b. Instalação de caráter museológico e simbólico.

\section{Ponto 6.}

Objetivo Comunicacional: desdobramentos relativos ao enfoque temático central a partir da imersão no universo da pesquisa arqueológica e da expansão da fruição do sítio arqueológico e da paisagem.

Campo Temático (eixo/abordagem), Elementos de conteúdo e Recurso Comunicacional:

XIII. Enterramentos.

XIII.1. Características dos enterramentos encontrados no Hatahara.

XIII.1.a. Escavação arqueológica real para fins didáticos;

XIII.1.b. Articulação expográfica entre texto, ilustrações.

\section{Centro Técnico - Laboratório aberto à visitação.}

Objetivo Comunicacional: desdobramentos relativos ao enfoque temático central a partir da imersão no universo da pesquisa arqueológica e da expansão da fruição do sítio arqueológico e da paisagem.

Campo Temático (eixo/abordagem), Elementos de conteúdo e Recurso Comunicacional:

XIV. Objetos, métodos e conceitos da arqueologia.

XIV.1. Vestígios pesquisados;

XIV.1.a. Articulação expográfica de ilustrações, artefatos e materiais manuseáveis.

XIV.2. Reconhecimento e interpretação dos materiais coletados.

XIV.2.a. Articulação expográfica de ilustrações, artefatos e materiais manuseáveis. 


\section{XIV.3. Sistematização e guarda de materiais coletados. \\ XIV.3.a. Reserva técnica didática aberta à visitação.}

\section{Ponto 7.}

Objetivo Comunicacional: desdobramentos relativos ao enfoque temático central a partir da imersão no universo da pesquisa arqueológica e da expansão da fruição do sítio arqueológico e da paisagem.

Campo Temático (eixo/abordagem), Elementos de conteúdo e Recurso Comunicacional:

$X V$. Solo antropizado e camadas estratigráficas.

XV.1. A natureza, o aspecto e a dimensão da Terra Preta sedimentada ao longo do tempo de ocupação e mesclada com vestígios de atividade humana.

XV.1.a. Fruição imersiva de uma trincheira aberta com o impacto visual e material do solo antropizado, das camadas estratigráficas e das ocorrências arqueológicas.;

XV.1.b. Articulação expográfica de texto, ilustrações e sinalização das ocorrências arqueológicas no paredão aberto.

\section{Ponto 8.}

Objetivo Comunicacional: desdobramentos relativos ao enfoque temático central a partir da imersão no universo da pesquisa arqueológica e da expansão da fruição do sítio arqueológico e da paisagem.

Campo Temático (eixo/abordagem), Elementos de conteúdo e Recurso Comunicacional:

XVI. Organização espacial das ocupações humanas.

XVI.1. Aspecto, distribuição e natureza dos montículos.

XVI.1.a. Fruição da ocorrência de montículos na paisagem de uma zona prédefinida de concentração dos mesmos;

XVI.1.b. Articulação expográfica entre texto, ilustrações e baixo-relevos das hipóteses de assentamentos dos diferentes períodos.

\section{Ponto 9.}

Objetivo Comunicacional: desdobramentos relativos ao enfoque temático central a partir da imersão no universo da pesquisa arqueológica e da expansão da fruição do sítio arqueológico e da paisagem.

Campo Temático (eixo/abordagem), Elementos de conteúdo e Recurso Comunicacional: 
XVII. Arqueologia.

XVII.1. Temáticas extraídas dos estudos em andamento sobre o próprio sítio e sobre a Amazônia em geral.

XVII.1.a. Articulação expográfica entre texto, ilustrações, peças multimídia etc.

\section{MódULO IV - ENCERRAMENTO E BALANÇO}

\section{Exposição B no Centro de Acolhimento/ Exposição Final.}

Objetivo Comunicacional: sintetizar as informações transmitidas na vivência do sítio musealizado.

Campo Temático (eixo/abordagem), Elementos de conteúdo e Recurso Comunicacional:

XVIII. Arqueologia.

XVIII.1. Diversas temáticas em exposição temporária.

XVIII.1.a. Articulação expográfica entre textos, ilustrações, modelos etc.

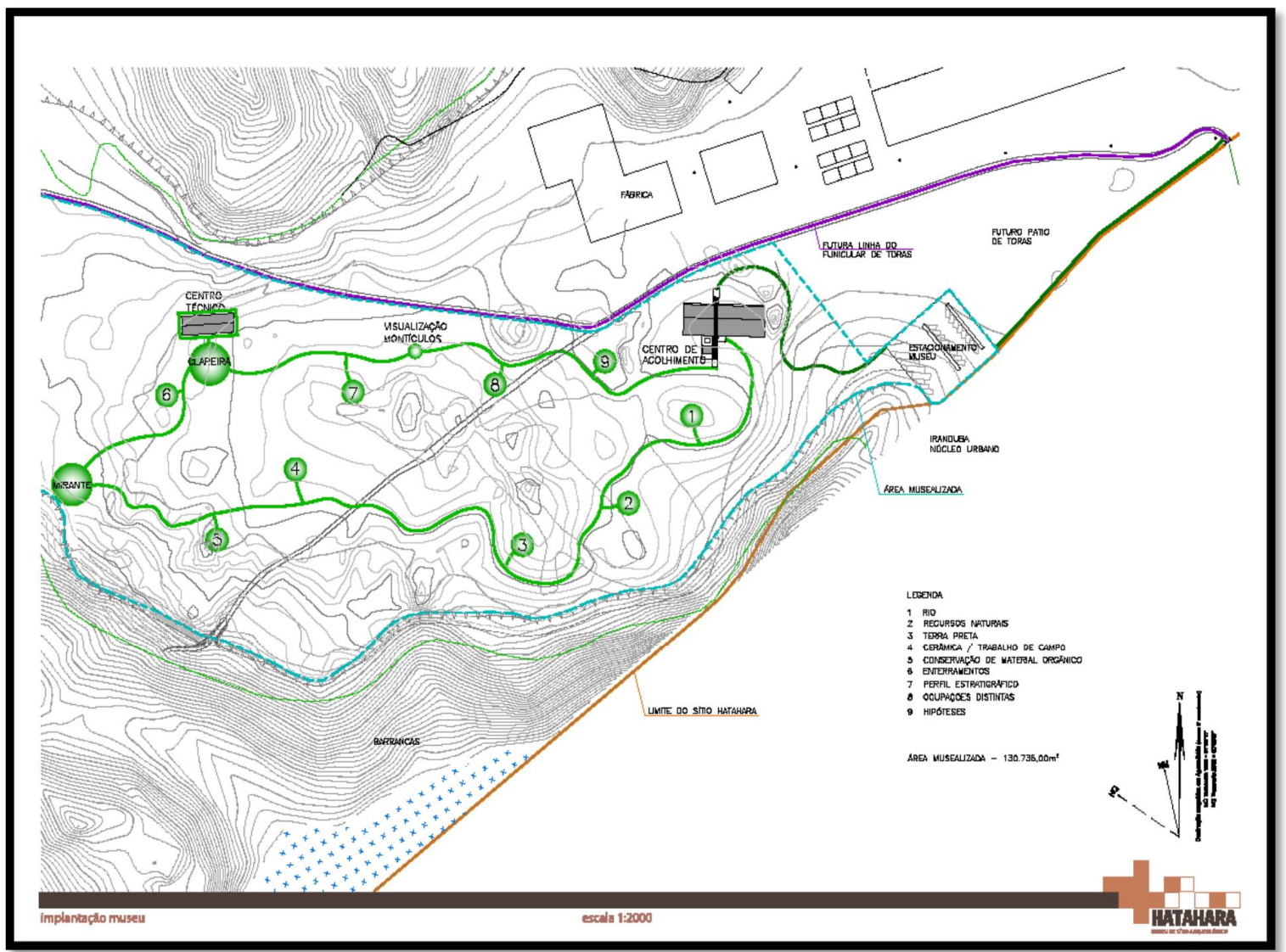

llustração IV.3: Mapa de implantação do Museu com a localização do Centro de Acolhimento, do Centro Técnico e da Trilha Exploratória (Fonte: Verde Volta Ass. e Rec. Amb. LtdA., 2009). 

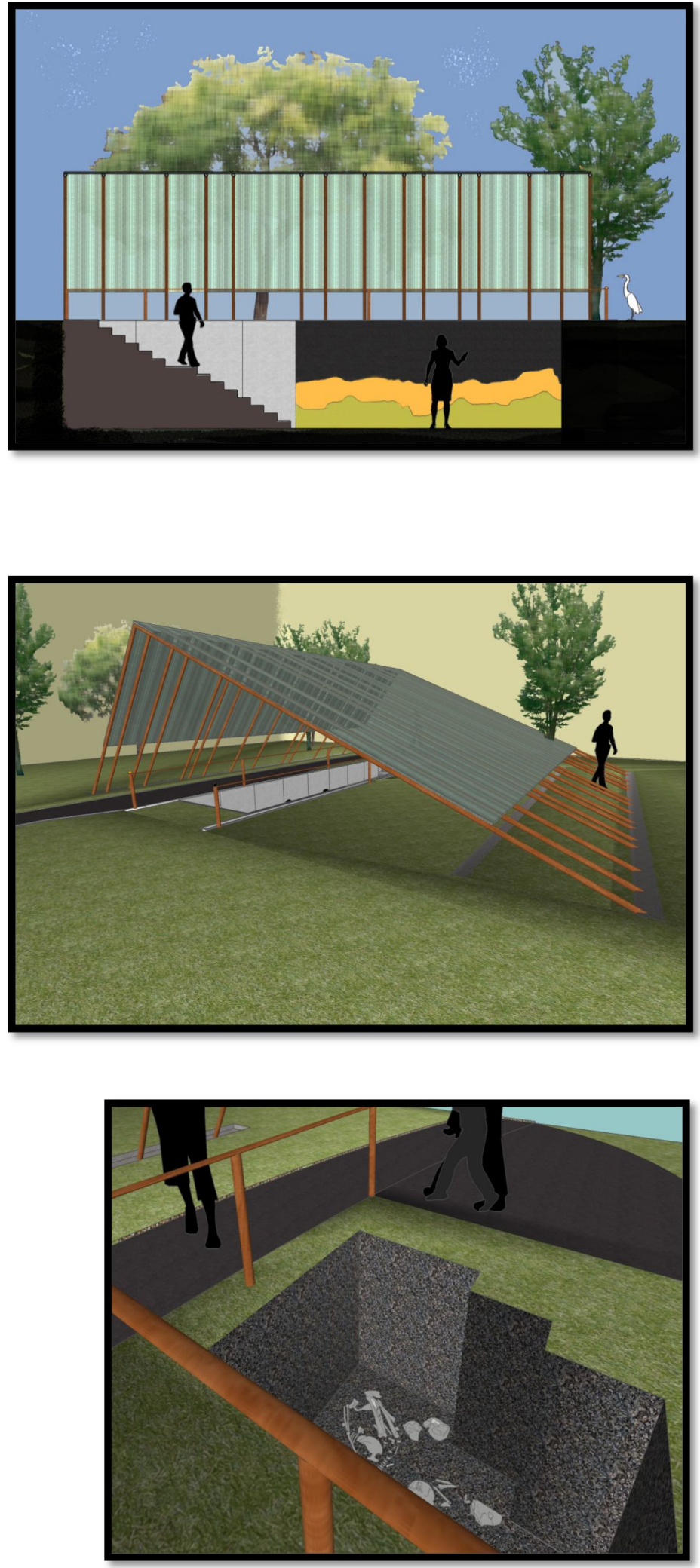

llustração IV.4: Perspectiva artística de uma trincheira reaberta, com acesso ao público e proteção contra intempéries (FonTE: VERDE Volta Ass. e Rec. Amb. LtDA., 2009). Considera-se que 0 posicionamento dos visitantes diante de um perfil estratigráfico é a chance de sentir o peso dos séculos de ocupação humana da área que se apresenta nas camadas de solo antropizado misturado a outros vestígios variados. A viabilidade dessa trincheira será avaliada

llustração IV.5: Perspectiva artística da cobertura das áreas abertas (FonTE: VERDE Volta Ass. e Rec. Amb. LtDA., 2009).

São coberturas leves, com estrutura metálica que descarrega seus esteios sobre duas vigas baldrame de aço, que somente aparentam estar apoiadas no chão, mas que, na verdade, transferem o peso para apenas quatro pontos escavados no solo, diminuindo o impacto dessa estrutura sobre o sítio.

Ilustração IV.6: Perspectiva artística da reabertura de uma área escavada em 2006, conhecida como área das urnas (Fonte: Verde Volta Ass. E REC. AMB. LTDA., 2009).

Inserção de réplicas das urnas, nos locais aproximados onde elas foram encontradas, mostrando a reutilização do espaço. 

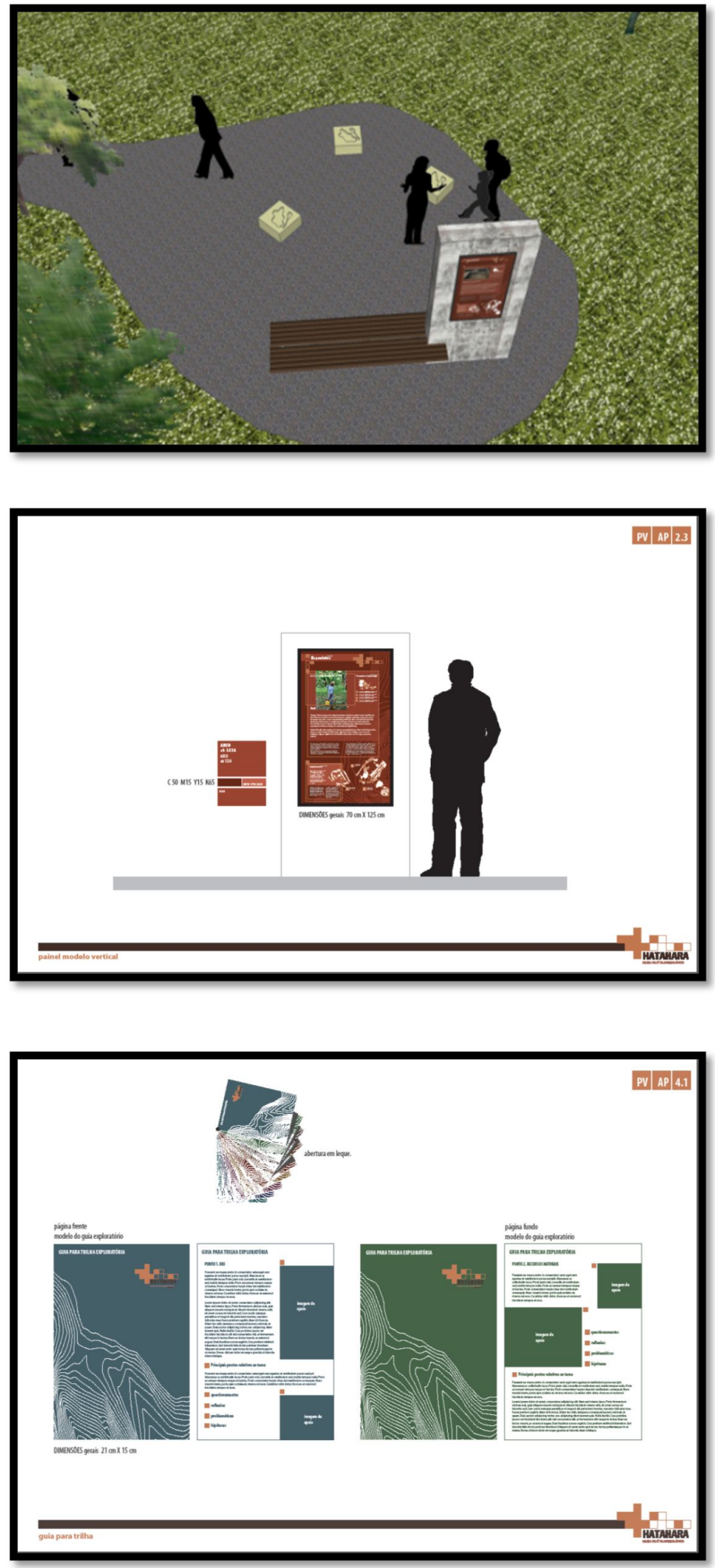

llustração IV.7: Perspectiva artística dos pontos do percurso. (FonTE: VERDE VolTA Ass. e ReC. Amb. LTDA., 2009).

llustração IV.8: Perspectiva artística dos painéis verticais (Fonte: Verde Volta Ass. e Rec. AMB. LTDA., 2009).

llustração IV.9: Perspectiva artística do Guia da Trilha (Fonte: Verde Volta Ass. e Rec. AMB. LTDA., 2009).

Este guia foi pensado para dar apoio à visitação espontânea. Nele estarão informações complementares sobre cada ponto da Trilha Exploratória. As páginas são unidas em apenas uma extremidade, permitindo um manuseio rápido e segue a coloração definida para cada ponto, facilitando uma rápida identificação do conteúdo. 
Considerações sobre a Elaboração do Anteprojeto de MusealizaçÃo do sítio ARQueológico HATAHARA.

O trabalho, previsto para ser realizado em seis (06) meses, sofreu atraso de três (03) meses, sendo finalizado no mês de agosto de 2009. Parte do atraso deu-se devido a problemas ocorridos entre a empresa proprietária do terreno onde se encontra o sítio arqueológico e integrantes, e ex-integrantes, do PAC. Esses problemas relacionavam-se às prospecções arqueológicas que ajudariam a delimitar o sítio arqueológico e liberariam a construção dos galpões da empresa. O fato de este projeto possuir pesquisadores do PAC, mesmo que sem nenhuma relação direta entre os dois trabalhos, gerou reflexos negativos e interferiu na comunicação entre a VERDE VOLTA e os representantes locais da empresa proprietária do terreno, dificultando o processo de elaboração do Anteprojeto. Devido a essa situação, ações fundamentais, como discutir o Anteprojeto, durante a sua elaboração, com diversos atores locais, dentre os quais a prefeitura e, principalmente, à própria empresa proprietária do terreno onde o sítio arqueológico se encontra, ficaram comprometidas.

Quando o produto final foi entregue ao IPHAN, o novo superintendente regional, Sr. Juliano Valente, convocou uma coletiva de imprensa para divulgação do Anteprojeto (ANEXOS 02, 03 E 04). Na mesma semana, o anteprojeto foi apresentado à AMAZONASTUR, que se mostrou interessada em unir esforços ao IPHAN no sentido de viabilizar a proposta.

No início de 2010, o IPHAN propôs, no seu orçamento anual, uma verba para a elaboração do Projeto Executivo. Isto seria um passo fundamental para o detalhamento da proposta, a definição dos materiais, dos métodos de ação e, finalmente, para se chegar a um orçamento para a construção do museu. No entanto, o processo esmoreceu. Não se sabe ao certo, até o atual momento, se algo será feito naquele local, quando será feito e por quem será feito. As últimas informações disponíveis apontam para um investimento autônomo por parte dos proprietários do terreno, já que parte do anteprojeto (p. ex., a localização do prédio e os estacionamentos) teria tomado uma direção oposta à vontade dos mesmos. Essa falta de consenso sobre quem assumirá a responsabilidade final pela consecução do projeto tem sido, aparentemente, um fator complicador para a continuidade da proposta.

Porém, acredita-se que foi cumprido o objetivo de demonstrar a possibilidade de tornar um sítio cerâmico, totalmente enterrado - cuja aparência atual é apenas de uma plantação de 
mamão e banana abandonada - num equipamento capaz de integrar funções de preservação, educação e cultura, que pudesse servir de atrativo a um público bastante amplo e diversificado, apresentando-se tanto ao trabalho de EP, como ao turismo. Por tudo isso, acredita-se que novos esforços devem ser empreendidos no intuito de dar continuidade a esta ideia.

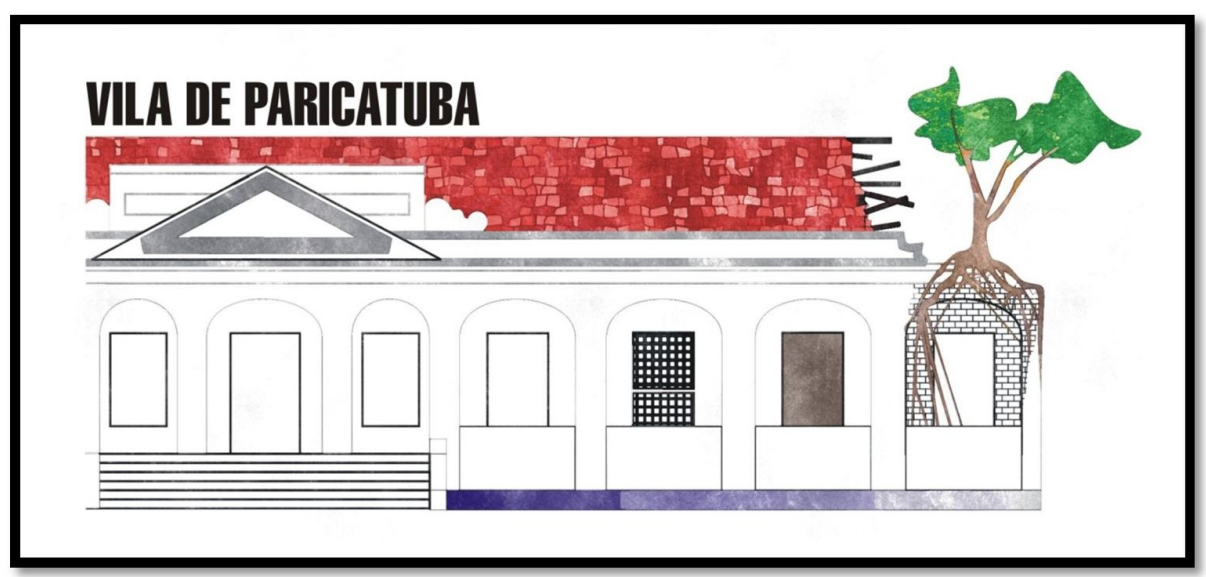

Ilustração IV.10: Logo para a Vila de Paricatuba interpretada (ARTE: Gustavo Accacio).

IV.2.2. (DES)CONTINUIDADES: O MESMO ESPAÇO, DIFERENTES HISTÓRIAS - INTERPRETAÇÃO E SinAlizaÇão da Vila de PARICATUba.

O tema (Des)continuidades: o mesmo espaço, diferentes histórias foi escolhido pensando-se não apenas no período posterior ao da construção do prédio e em seus diversos usos, mas, também, na ocupação antiga da localidade pelos indígenas e na ocupação atual.

Dentro da linha que este trabalho vem seguindo, decidiu-se por elaborar um plano preliminar para a interpretação do patrimônio arqueológico local. Como não havia verbas para elaborar um anteprojeto nos moldes do que foi realizado na proposta anterior, optouse por realizar o trabalho individualmente, mesmo reconhecendo que essa situação não seja ideal, considerando tudo que foi discutido sobre envolvimento de diversos profissionais em propostas desse tipo. Deste modo, preferiu-se partir do histórico da localidade, apresentado no capítulo anterior, tendo-se sempre como base os depoimentos (de comunitários ou pessoas de fora da comunidade, mas que, em algum momento, tiveram contato com o patrimônio) encontrados nas fontes consultadas, como uma reportagem publicada no Jornal 
da Ciência (JC e-mail 2804, de 05 de Julho de 2005), postagens no Blog do Rocha ${ }^{96}$, um artigo (NETO, 2005), uma dissertação de mestrado (PESSOA, 2010), um artigo não publicado, citado no capítulo anterior (DUARTE et al., 2002), além de todo o material, sem bibliografia, que foi gentilmente cedido a esta pesquisa pelos professores da FUNDAÇÃO BRADESCO, dentre os quais muitas fotografias e textos digitalizados ${ }^{97}$.

O PLANO INTERPRETATIVO

Ponto 1 - Placa de Boas-Vindas na entrada da Vila.

Ponto 2 - Saída de pedestre do estacionamento. (Des)continuidades: o mesmo espaço, diferentes histórias.

- Apresentar a Vila de Paricatuba e convidar o visitante para vivenciar sua história.

- Aguçar o olhar do visitante para as diferentes etapas históricas do local.

- Apresentação do mapa da comunidade, com indicação das edificações históricas, das áreas arqueológicas escavadas, das casas atuais e dos espaços de convivência.

- Sinalização, ao longo do caminho principal, por meio de imagens (fotos antigas, desenhos e fotografias atuais).

\section{Ponto 3 - Sítio Arqueológico pré-colonial. As primeiras ocupações.}

- Refletir sobre o que sobrevive na nossa história e como algumas partes da mesma podem ser simplesmente esquecidas.

- Observação de áreas com afloramento de materiais arqueológicos na Vila de Paricatuba, com auxílio de intérpretes locais e painéis interpretativos.

- Exposição de vitrines com coleção de artefatos arqueológicos descontextualizados, coletados por comunitários.

\footnotetext{
${ }^{96}$ Endereço: http://jmartinsrocha.blogspot.com.br/2006 0301 archive.html. Último acesso: fev./2012.

97 Os depoimentos e trechos de artigos foram transcritos na íntegra, sem correções ou modificações de qualquer tipo.
} 


\section{Ponto 4 - Prédio. Uma construção e muitas memórias}

- Espaço 1. A construção. (Ilustrações IV.11 e IV.12)

- Apreciação da construção em si (materiais construtivos utilizados, as formas e o tamanho, destoantes da paisagem) e reflexão sobre a sua importância para a história de Paricatuba, do Amazonas e do Brasil. Construção de uma maquete do prédio e suas construções associadas; articulação de imagens, fotografias antigas e recentes, que remetam à importância histórica do prédio, relatando, inclusive, as visitas ilustres ao local; reprodução da poesia 'Riqueza da Amazônia' no hall central do prédio.

\section{Riqueza da Amazônia}

Você que é amante da natureza Ihe convido a visitar Iranduba

Se você gostar de beleza Ihe apresento as Ruínas de Paricatuba

Um monumento que faz maravilhar qualquer um que vê

Desperta sentimentos

E recomendo a história conhecer

Um prédio que não é só monumento

Mas sim um prédio que guarda amores, flores e até mesmo sentimentos

Uma ruína que parece até humana

E presenciou sofrimento

Que não sejam esquecidos

E que lembrem bem

as histórias que foram vividas

Que percebam a maravilha que tem

Nós também fazemos parte dessa grande e eterna obra de arte

Não se pode deixar essa imagem morrer

$O$ monumento e a natureza fundidos

É impossível não perceber os dois unidos

Não podemos deixar nossa história acabar

Faz parte de nós o município de Iranduba

Vamos cuidar e preservar

Da nossa Ruína de Paricatuba

Poesia: Bessey Benzecry Rodrigues de Lima, à época com 15 anos e cursando o 1ํ. ano do Ensino Médio da Fundação BRAdesco (Produção textual do Projeto Ruínas de Paricatuba). 
- Espaço 2. Hospedaria de Imigrantes

- Contextualização histórica da construção e apresentação paralela de outras construções do mesmo período na região (p.ex. o Teatro Amazonas).

- Espaço 3. Instituto de Artes e Ofícios Affonso Penna

- Mostra de fotos da época, cotidiano dos internos. Reprodução de móveis típicos da época, como as carteiras de estudantes utilizadas, entre outros móveis e objetos.

- Espaço 4. 1‥ Penitenciária de Manaus

- Recomposição de uma sala como uma cela, com materiais utilizados pelos presos. Reprodução de áudios com depoimentos de moradores locais e/ou narrações de trechos de livros, jornais e/ou outros registros de época que descrevam o cenário e o cotidiano.

"Ficou conhecido como Penitenciária da llha das Cobras, nome atribuído ao vilarejo de Paricatuba, neste período" (DUARTE et al., 2002. Pastor Sabá, morador da comunidade).

- Espaço 5. Leprosário Belizário Penna

- Reprodução de áudios com depoimentos de moradores locais, reprodução de um filme (remontagem) sobre esse período.

"Eram 666 pessoas internadas aqui. Isso aqui funcionava como uma casa para eles. Ele tinha direito a rancho, casa, médico. Os médicos daqui eram o Dr. Chrichanã, Mena Tapajós e Dr. Geraldo. Era os especialistas daqui" (JC. Ricardo Ozório da Silva, 66 anos, aposentado que trabalhou na caldeira do hospital durante 30 anos, sendo um dos 14 funcionários. Trabalhava na caldeira que abastecia água).

"Quem não tinha hanseníase não entrava aqui dentro. Os doentes tinham seus locais. Tinha o apartamento das crianças, das mulheres, dos rapaz solteiros, dos velhos. Tudo era separado. Mas, de vez em quando os doentes acabavam se apaixonando e namoravam. Só podia namorar aqui doente com doente" (JC. Ricardo Ozório da Silva, idem anterior).

"Essas salas eram imensas, mas aqui existia muita segregação, principalmente na época do hospital de hansenianos. Há relatos de que aqui houve uma grande festa. Eles colocaram umas cadeiras no meio para dividir. De um lado dançavam os doentes e do outro os sadios. Existia um parlatório onde um vidro divida os sãos e os doentes. As crianças que nasciam aqui eram levadas para adoção lá no Gustavo Capanema (Manaus). Tem mulheres aqui 
que tiveram sete filhos e não conheceu nenhum. Eu costumo dizer que paira sobre Paricatuba uma energia de dor. Então, precisamos mudar isso". (JC. Rosângela Barbosa, moradora local, familiar de paciente).

- Espaço 6. Área sem restauro (Ilustração IV.14). Nem a destruição nem o tempo podem apagar memórias.

- Contraponto entre a forma escolhida para finalizar as atividades do leprosário e a vontade de muitos pacientes e familiares em permanecer no local.

- Espaço com áudio, com falas de moradores, ou vídeos, com depoimentos e sons de destruição, jogos de luz e sombras.

"Para forçar as pessoas a saírem daqui eles começaram a depredar o prédio. Eles começaram cortando a água, tiraram os suprimentos, destruíram o telhado, tiraram as calhas e estimulavam que esse material fosse vendido. Existia aqui um troller que carregava os mantimentos que chegava na terra para vir para cá. O relato que a gente tem é que esse trailer foi martelado para impedir para chegar aqui. Ele foi levado para Manaus e como era muito ferro não pode ser vendido. E, aí jogaram no rio Negro"

(JC. Rosângela Barbosa, moradora local, familiar de paciente).

"O local era administrado pelas Freiras Franciscanas. Estas, encabeçadas pela Freira Fernanda, considerada por todos um terror, e com o aval do governador Artur Reis, destruíram o Leprosário.

(...)

As telhas, algumas foram enviadas para a Colônia do Aleixo, outras foram roubadas por moradores do São Raimundo, as calhas de cobre, foram vendidas pelas Freiras para fundição. O mesmo aconteceu com a roda d'água, que era de ferro fundido. Após a destruição e abandono do prédio, a comunidade recém formada, contribuiu também para a depredação do Hospital, roubando tijolos e as telhas restantes. Parte do que sobrou do prédio e que estava em condições de uso, serviu como centro comunitário e escola - A Escola Santa Terezinha funcionou por aproximadamente 20 anos neste local" (DUARTE et al., 2002. Pastor Sabá, morador da comunidade)

- Espaço 7. Provocação final sobre a quem pertence a construção, de quem é o dinheiro que foi investido ali e a quem interessam as memórias que rondam o local. Exposição de fotos do estado de abandono em que o prédio permaneceu por muitos anos. Deixar uma área do prédio da forma como se encontra hoje, com as paredes abraçadas pelas raízes das árvores, sem telhado.

"É uma construção que foi feita para durar a vida toda. Todas essas paredes internas era revestidas com azulejo, todos os assoalhos eram de pinho, as calhas eram de cobre, as 
caixas de descarga eram ferro. Era um material muito caro e de ótima qualidade que foi tudo jogado fora. Um desperdício do dinheiro público" (JC. Rosângela Barbosa, moradora local, familiar de paciente).

"Eu nunca tinha ouvido falar naquele monumento gigantesco" (Kleberson Worslley de Souza, professor de educação ambiental da Fundação Bradesco, de Manaus).

\section{Ponto 5 - Vila de Paricatuba / comunidade atual.}

- Convite para explorar o espaço da Vila de Paricatuba.

- Mapa com sugestão de roteiro e interpretação de alguns pontos. Cada ponto pode estar numerado e as informações podem constar em um guia, por exemplo.

- Relação de bares, restaurantes, barracas e lojas de artesanato abertos ao público.

- Oferecimento de um calendário de eventos, como p. ex. a comemoração da construção do prédio, data em que pode haver uma representação interpretativa dos períodos de "vida" daquele espaço.

"No contexto de todo um período de existência, a cultura e a história regional de Paricatuba é marcada pela presença de índios, por uma escola de artes e pela presença de franceses e italianos, além de outros agentes da história que representam diversidade e identidade cultural. Como herança cultural, podem-se ter de volta as festas, danças e as culinárias regionais, indígena, francesa e italiana, e celebrações como novenários, e a Festa de Santa Terezinha, que seria a padroeira da localidade, que um dia marcaram o calendário da Vila. É por isso que, as manifestações ocorrem entre um elo de tradições e novos comportamentos, típicos da dinâmica cultural da modernidade" (NETO, 2005).

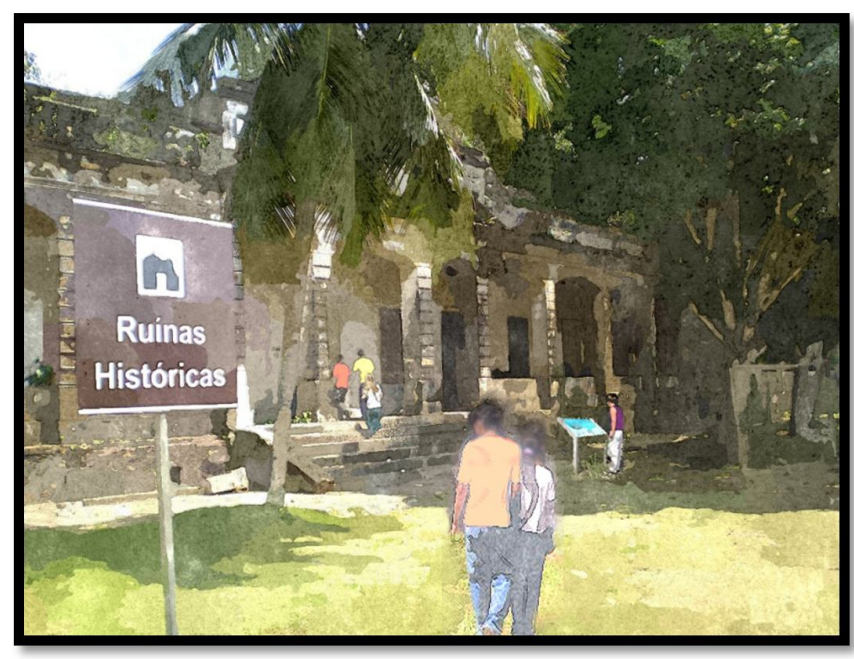

llustração IV.11: Fachada restaurada, placas de sinalização e painel interpretativo (ARTE: Gustavo Accacio). 


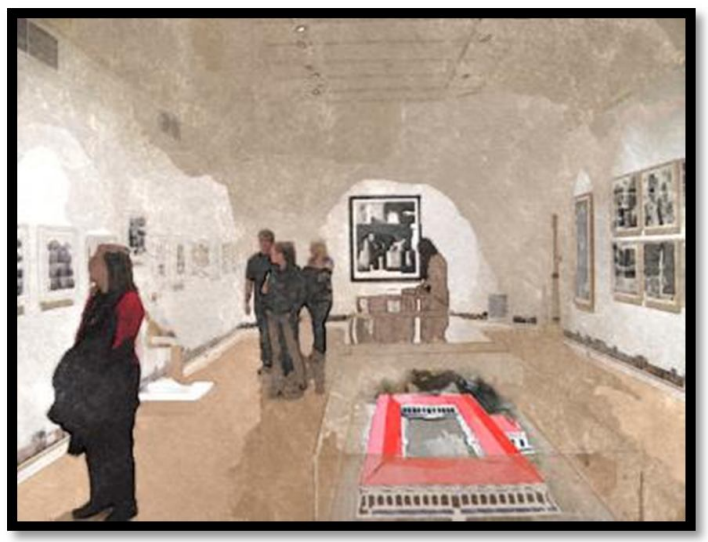

Ilustração IV.12: Sala expositiva com maquete, reprodução de vídeo, fotografias etc. (ARTE: Gustavo Accacio).

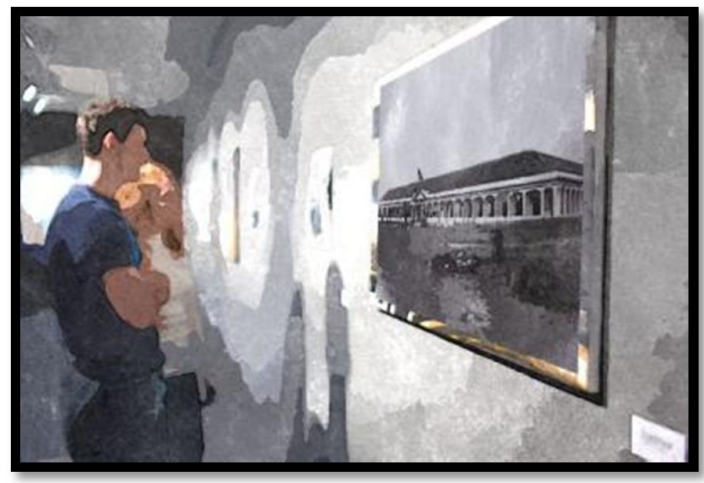

Ilustração IV.13: Exposição de fotografias (ARTE: Gustavo Accacio).

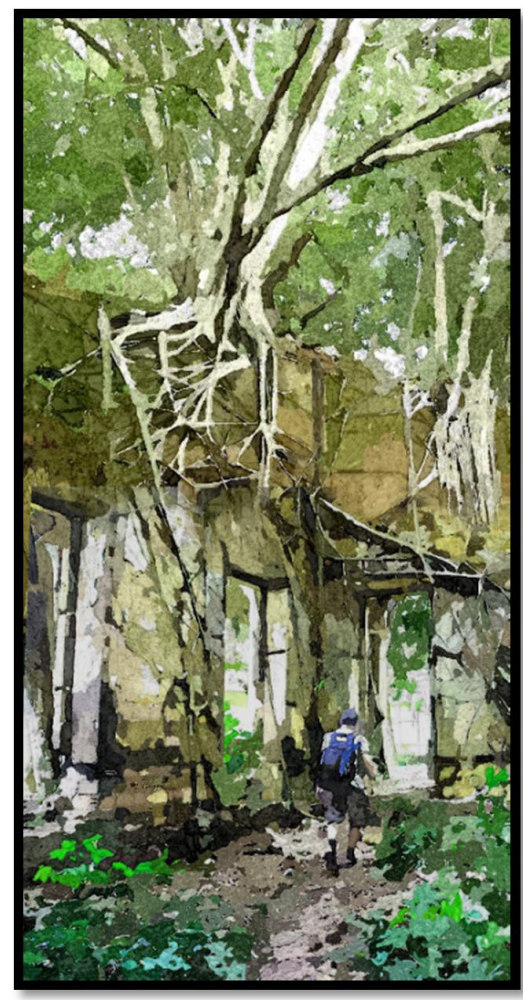

Ilustração IV.14: Espaço com manutenção controlada da situação em que o prédio permaneceu durante anos (ARTE: Gustavo Accacio). 
CONSIDERAÇÕES SOBRE A PROPOSTA DE INTERPRETAÇÃO E SINALIZAÇÃO DA VILA DE PARICATUBA.

Essa proposta extrapola a existência do prédio em ruínas, considerando também o sítio arqueológico pré-colonial existente em Paricatuba e a própria comunidade atual, além de sugerir o aproveitamento de um conjunto de peças arqueológicas descontextualizadas, que hoje são guardadas pelos comunitários (Ilustração IV.15).

O processo de discussão das ideias e a elaboração do plano podem possibilitar, imensamente, a comunidade a refletir sobre si mesma, avaliar seu presente e redefinir o seu futuro. Por isso, ressalta-se, mais uma vez, que o que aqui se apresenta busca apontar um caminho para o aproveitamento arqueoturístico do local. Porém, este caminho precisa ser redesenhado a partir de um processo participativo e do aprofundamento na bibliografia histórica. Embora se tenha utilizado distintos testemunhos pessoais locais na sua elaboração, pressupõe-se que o contato com os moradores atuais, as histórias dos que vivenciaram o período de funcionamento do Leprosário e o resgate das memórias dos filhos e netos dos seus pacientes, certamente enriquecerá qualquer plano interpretativo para o local, já que qualquer história precisa ser contada a partir de diferentes versões. Nesse sentido, concorda-se com Chuva (2011: 48), quando ela diz que "os limites da História são, paradoxalmente, o espaço da esperança e do sonho: propiciar diferentes versões do passado é ao mesmo tempo aquilo que nos coloca em movimento, que nos mantem na luta".

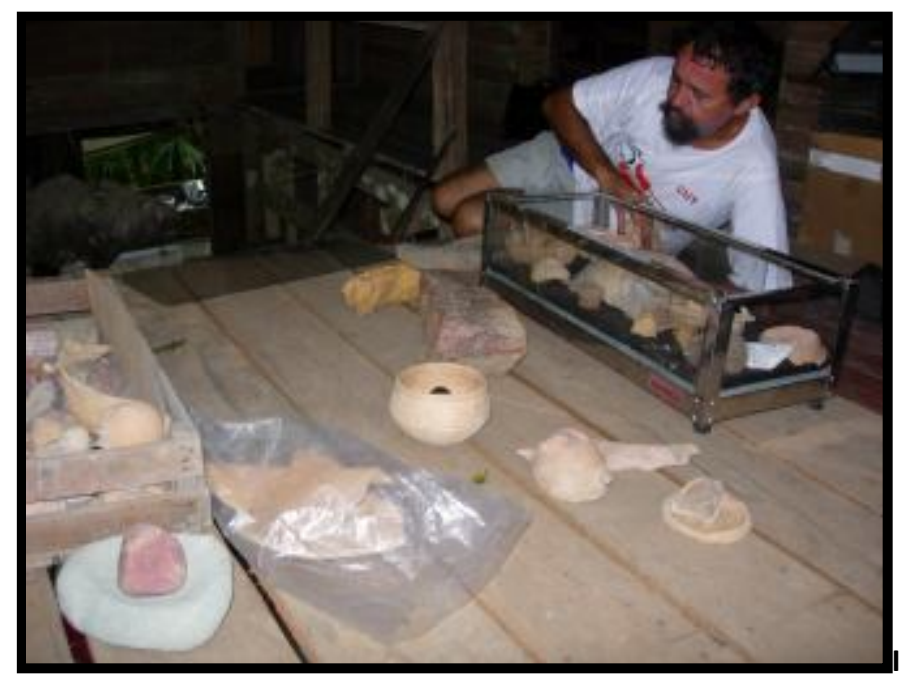

llustração IV.15: Coleção sob a guarda de comunitário em Paricatuba (FotografiA: Adriana Guimarães, 2006). 


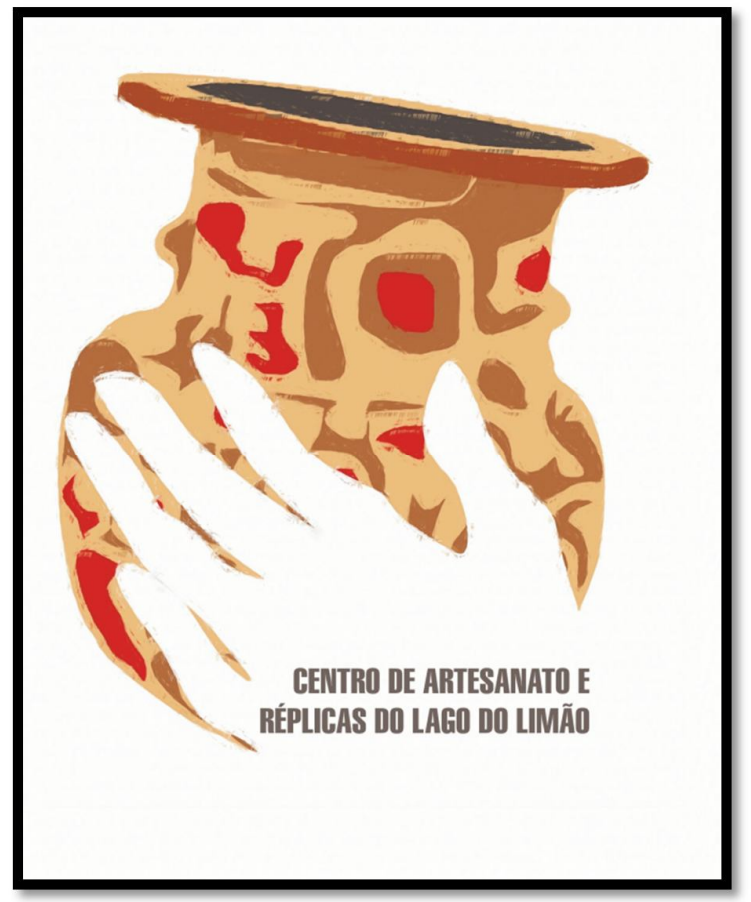

Ilustração IV.16: Logo para o Centro de Artesanato e Réplicas do Lago do Limão (ARTE: Gustavo Accacio).

IV.2.3. InSPIRAÇÃO E LEMBRANÇAS - CENTRO de ARTESANATO E RÉPLICAS No LAGO do LiMÃo.

O tema Inspiração e Lembranças foi escolhido por traduzir exatamente a experiência que aqui se propõe. Através da criação de um Centro de Artesanato e Réplicas voltado à temática arqueológica no Lago do Limão, a arqueologia serviria como inspiração para a comunidade local e seria "levada" como lembrança pelos visitantes na forma de souvenirs (Ilustração IV.17).

Esta proposta sugere a produção de souvenirs e de réplicas. São duas frentes de trabalho diferentes, com justificativas distintas, mas que buscam aproximar a sociedade da ciência arqueológica: (a) a comunidade diretamente envolvida no projeto e as comunidades de entorno dessa iniciativa terão suas consciências modificadas ao perceberem como suas vidas podem ser transformadas a partir da valorização de algo até então desprezado por elas, tornando, desse modo, a preservação do patrimônio arqueológico viável em seus cotidianos; (b) os turistas, porque terão a chance de adquirir produtos que vão além da estética das 
peças, mas que terão forte conotação de resgate histórico e de transformação social e (c) alunos e professores do país e do exterior, que poderão acessar réplicas de materiais arqueológicos, dinamizando a forma de ensino e aprendizagem da arqueologia. A seguir detalham-se as justificativas para cada produção.
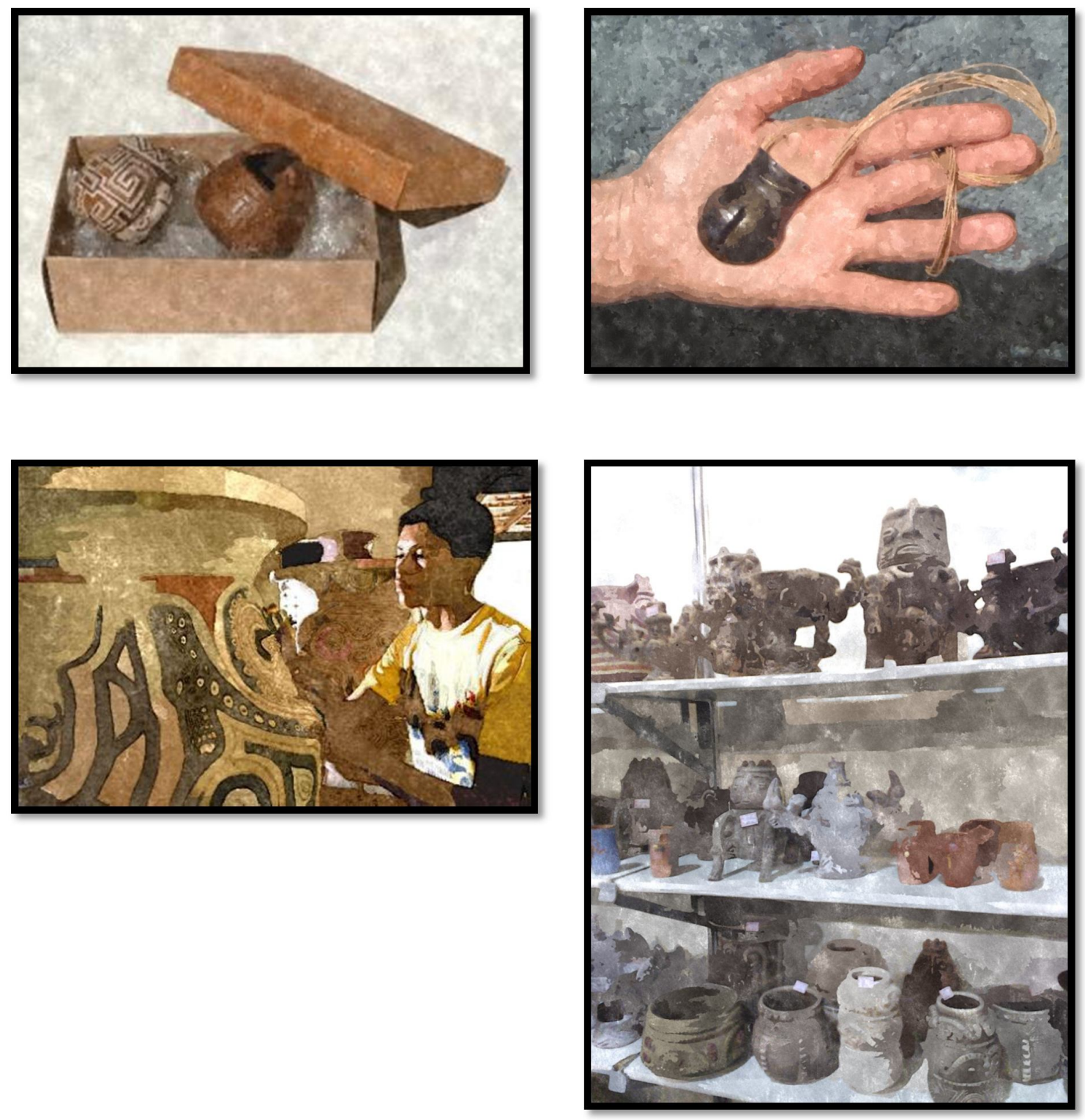

Ilustração IV.17: Ilustração artística do funcionamento do Centro de Artesanato e Réplicas no Lago do Limão (ARTE: Gustavo Accacio). 
A produção de souvenirs está associada diretamente à atividade turística. Os souvenirs representam o desejo dos turistas em possuírem uma lembrança do local visitado, confirmar aos amigos que estiveram no local e, em algumas situações, o desejo em colaborar financeiramente com as comunidades. Contudo, atualmente, peças do mesmo tipo são encontradas em diversos locais turísticos, sem nenhuma preocupação com a relação entre a cultura local e o objeto oferecido. Essa padronização já é percebida como um ponto negativo para a ocorrência das vendas de souvenirs.

Para sobreviver à tendência de convergência nesse mercado, há necessidade de salvaguardar a vantagem competitiva da "originalidade", já que, segundo Jansen-Verbeke (2001):

[a]s compras dos turistas estão quase sempre classificadas como compras por diversão, ou seja, são impulsivas, estimuladas pela estética dos produtos e pela sensibilidade ao contexto no qual o produto é vendido.

Assim, enfatizar os laços culturais com a comunidade hospedeira e com as suas tradições, conservar a arquitetura original e compreender o apelo local são políticas que contribuem com a originalidade e com a consciência de percepção de lugar, que parece ser vital à qualidade da experiência turística (JANSEN-VERBEKE, 2001).

Como já comentado neste trabalho, a Amazônia, enquanto produto turístico, tem apelo voltado à floresta em si. Mas, apesar da venda de pacotes sob a égide do Ecoturismo, há pouca preocupação com a cultura e, em geral, com as próprias comunidades locais. $\mathrm{Na}$ grande maioria dos casos, apenas comunidades indígenas recebem algum destaque.

Todavia, é incoerente que a toda a cultura existente na enorme quantidade de sítios arqueológicos locais, repletos de vestígios de sociedades pretéritas, não reflita na produção artesanal, como acontece, por exemplo, no Pará, onde os vestígios arqueológicos de Santarém e da Ilha de Marajó, que chamam atenção por sua beleza e elaboração, são a inspiração para vasos (Ilustração IV.18), jóias em prata e ouro, miniaturas, camisetas, entre outras coisas. Em menor escala, isso também ocorre no Amapá. 


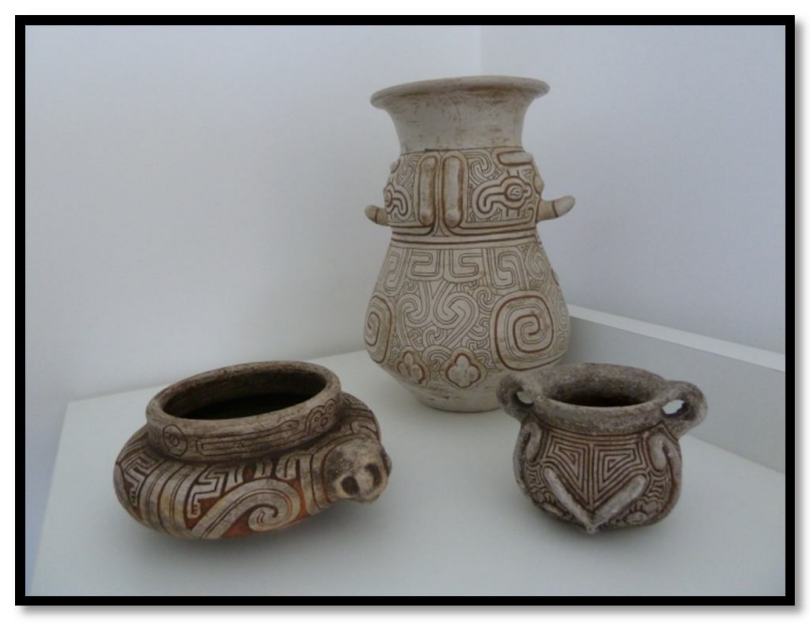

Ilustração IV.18: Vasos comprados em Belém, PA (FotografiA: Adriana Guimarães, 2012).

No estado do Amazonas, o artesanato típico é composto de produtos indígenas, chocolates com recheios de frutas regionais, biojóias, entalhes em madeira e animais em borracha/balata e cosméticos. Dificilmente se encontra, entre os souvenirs à disposição do turista, algo que apresente a temática arqueológica. As exceções são jóias que mesclam madeiras e sementes com a prata ou o ouro, vendidas apenas em lojas mais sofisticadas, e algumas camisetas vendidas nas lojas do Instituo Mamirauá (RDS Amaná). Entretanto, em todos os casos, não é feita nenhuma relação das figuras e desenhos ao que está sendo representado, ou seja, considera-se somente o elemento estético.

Portanto, há um nicho de mercado a ser explorado e, por isso, a proposta de implantação de um Centro de Artesanato e Réplicas no Lago do Limão considera que todo o trabalho de viabilização do Turismo Arqueológico na região deve ser complementado com a produção de peças artesanais que aliem-se , com originalidade, à temática arqueológica, oferecendo uma diversidade de opções e, fundamentalmente, prezando pela alta qualidade dos produtos. Neste caso, não se trata apenas de réplicas cerâmicas, que é o pensamento recorrente quando se trata de produtos com temática arqueológica, nem de impor aos comunitários um tipo de produto. A decisão sobre o produto final a ser oferecido deve partir da comunidade, de técnicas e conhecimentos pré-existentes e utilizando-se de materiais locais. Desta forma, a atuação de um designer seria mais para promover um intercâmbio de saberes e mais para aprimorar técnicas do que para ensiná-las.

Os souvenirs fabricados neste Centro podem ser disponibilizados a equipamentos turísticos que venham a ser criados no entorno de sítios arqueológicos no estado do Amazonas, em lojas em Iranduba, bem como em lojas em Manaus, inclusive em seu aeroporto. Contudo, vislumbra-se que o próprio Centro de Artesanato e Réplicas do Lago do Limão, se constitua 
no principal ponto de venda desses produtos, transformando-se, dessa forma, num atrativo turístico, na medida em que abrir as suas portas à visitação.

RÉPLICAS EM RESINA - COMO MATERIAIS DIDÁTICOS OU COMO SOUVENIRS.

A réplica de um fóssil ou de um artefato arqueológico é como a fotocópia de um livro. Conta-nos a mesma história e transmite-nos os mesmos conceitos do objeto original. As réplicas podem ser facilmente multiplicadas e alcançar um número muito grande de indivíduos (cidadãos, professores, alunos ou turistas).

Relaciona-se, frequentemente, o ensino da história brasileira apenas ao período que compreende os acontecimentos após o "descobrimento" do país, com a chegada de Pedro Álvares Cabral. No entanto, já há algum tempo, discute-se a adequação desse discurso. Afinal, em 1500, o território brasileiro encontrava-se praticamente todo ocupado por populações distintas, com culturas diversificadas. Como a visão preponderante desde então foi a do colonizador, muito do que se podia saber das pessoas que aqui se encontravam foi perdido e vem sendo resgatado pouco a pouco com a expansão da arqueologia brasileira.

No entanto, quase toda a produção científica relacionada à arqueologia brasileira permanece desconhecida dos brasileiros, dificultando essa readequação histórica. A produção e disseminação de réplicas arqueológicas permitiria maior aproximação e familiarização entre parcelas significativas de cidadãos e o patrimônio arqueológico do país, possibilitando um novo relacionamento dos brasileiros com uma parte ainda pouco conhecida de seu passado comum.

Com isso em mente, considerou-se válido expandir as atividades do Centro de Artesanato e Réplicas do Lago do Limão para além da produção dos souvenirs, incluindo a produção de réplicas, diante da percepção que: (i) existe carência desse tipo de material nas escolas brasileiras, (ii) há necessidade de oferecimento de materiais didáticos novos e interessantes por parte das instituições de ensino e, também, (iii) há necessidade de extensão do conhecimento científico ao maior número possível de pessoas. Além disso, a produção de 
réplicas alcança um mercado muito maior, gerando mais renda para a comunidade local, tendo como público potencial escolas, universidades e museus.

Para escolas de segundo grau e universidades, as réplicas possibilitam trazer para perto dos estudantes amostras de objetos que são representados, muitas vezes, por um único exemplar. O uso das réplicas protege os originais do manuseio e de quebra em salas de aula, garantindo a integridade física e cumprindo uma função didática importantíssima. Além de formar cidadãos mais bem preparados, a escola que oferece materiais didáticos diversificados aos seus alunos é melhor avaliada pelo Ministério da Educação, pais e usuários e, consequentemente, atrai mais estudantes.

As réplicas que estão sendo propostas aqui são fabricadas em resina (Ilustração IV.19), a partir de moldes em silicone, e acompanhadas de material didático ricamente ilustrado. Deste modo, podem ser produzidas réplicas individuais - p. ex. de materiais que se destaquem por sua estética elaborada ou importância cerimonial - ou podem ser formadas coleções (Kits) de determinados períodos ou de distintas regiões do país ou do mundo.
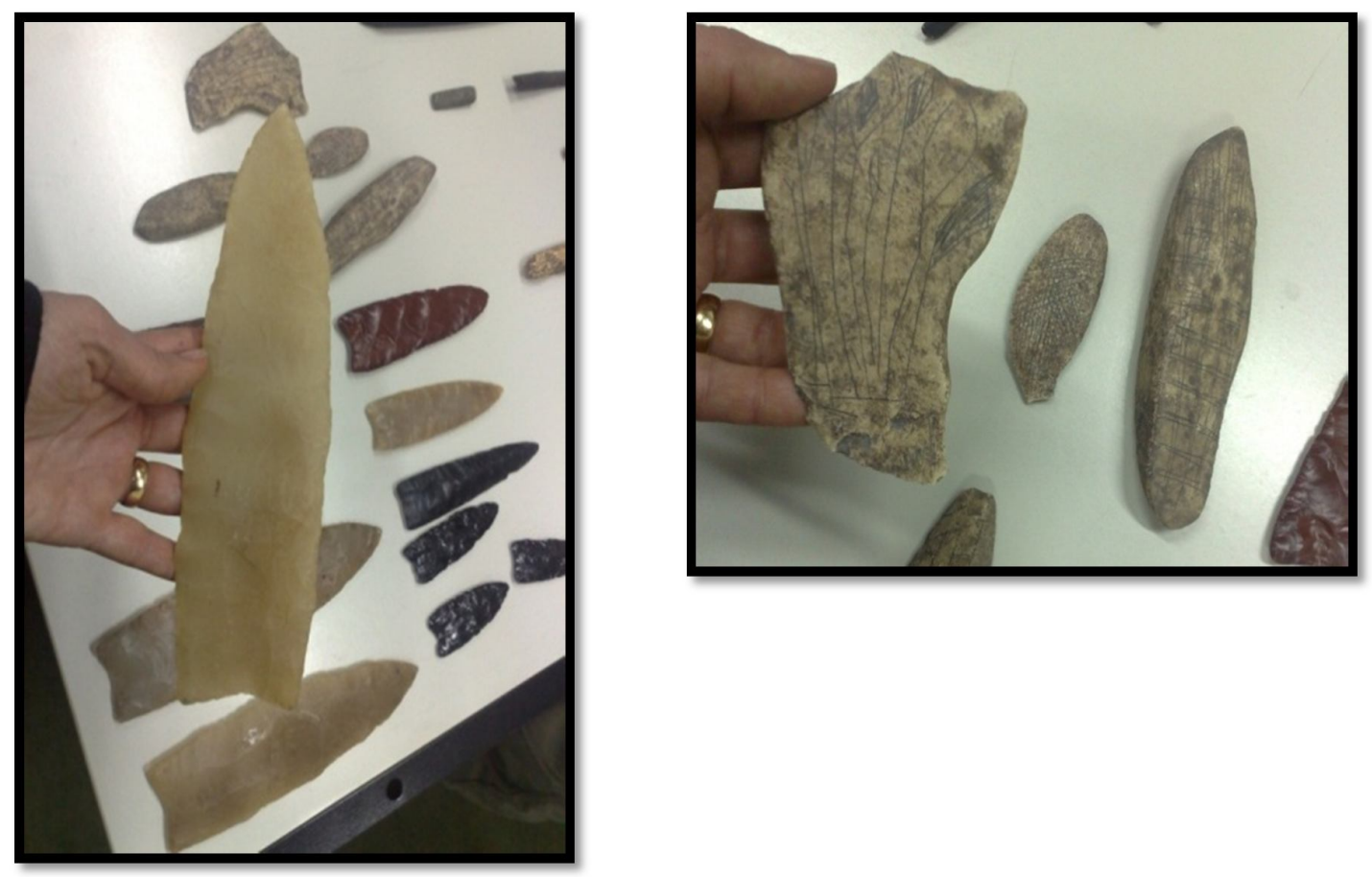

llustração IV.19: Exemplos de réplicas arqueológicas fabricadas em resina, apresentadas pelo Prof. Bruce Bradley, no EAPT Rio Claro, Jul. 2011 (FotografiAs: Adriana Guimarães, 2011). 
As réplicas arqueológicas baseadas nos vestígios arqueológicos locais, quando vendidas como souvenirs, ainda podem cumprir outro papel importante que é o de enfatizar laços culturais do local visitado para o turista, a partir da lembrança adquirida, sendo excelentes materiais para o comércio turístico, em substituição ao material original que, na atualidade, costuma deixar a região, ou mesmo o país, através do comércio ilegal. Porém, com o conhecimento adquirido, o Centro poderá expandir a sua produção, fabricando, entre outras possibilidades, réplicas de vestígios arqueológicos provenientes de várias regiões brasileiras, permitindo, dessa forma, outros tipos de relações comerciais com escolas e museus, por exemplo. Salienta-se que, neste caso, a produção de réplicas não segue a mesma lógica descrita para a produção de souvenirs locais, onde a originalidade e a pertinência regional são fatores fundamentais. A produção de réplicas, neste caso, adquire outra dimensão cultural e comercial.

Instituições museológicas do país e do exterior podem utilizar-se de réplicas na composição de acervos ou mesmo vendendo-as como souvenirs. As réplicas são excelentes materiais para compor exposições interpretativas nas mais diversas regiões do país ou do mundo, bem como podem ser trocadas com objetos produzidos por outras instituições, promovendo o intercâmbio acadêmico de material disponível em outros museus e universidades nacionais e estrangeiras. Vendidas como souvenirs, elas têm se mostrado importantes na sustentação dessas instituições (SILVA, 2006).

Diversos museus espalhados pelo Brasil são modestos e não conseguem formar coleções expressivas por falta de infraestrutura, corpo profissional especializado ou segurança. Estas instituições poderiam, entretanto, compor coleções de réplicas para serem expostas ao seu público local. Nesse sentido, as réplicas servem perfeitamente ao seu papel de ilustrar o passado, além de tornar o museu mais atrativo para o público, com consequente aumento do número de entradas/visitas. Moreira (2008), discorrendo sobre o que ele denomina de “triângulo tradicionalmente encarado como estruturante da instituição 'Museu' - edifício, público e acervo", explica que o acervo sofreu, ao longo dos tempos, alteração conceitual em vários sentidos, dentre os quais:

[N]a imaterialização do acervo, isto é, as peças deixam de valer somente pelo seu valor de mercado, mas, sobretudo, pelo seu valor evocativo e comunicacional. Ou seja, uma peça 
verdadeira ou uma réplica, do ponto de vista museológico, podem ter exactamente os mesmos préstimos (Moreira, 2008: 283).

Recentemente, por exemplo, no próprio estado do Amazonas, o Palacete Provincial, em Manaus, inaugurou uma exposição com réplicas de materiais arqueológicos importantes na história do mundo, que dificilmente poderiam ser vistos no Brasil. Essas réplicas, fabricadas em resina, permitem que o público local e os demais visitantes possam apreciar esses vestígios únicos na história da humanidade (Ilustração IV.20).
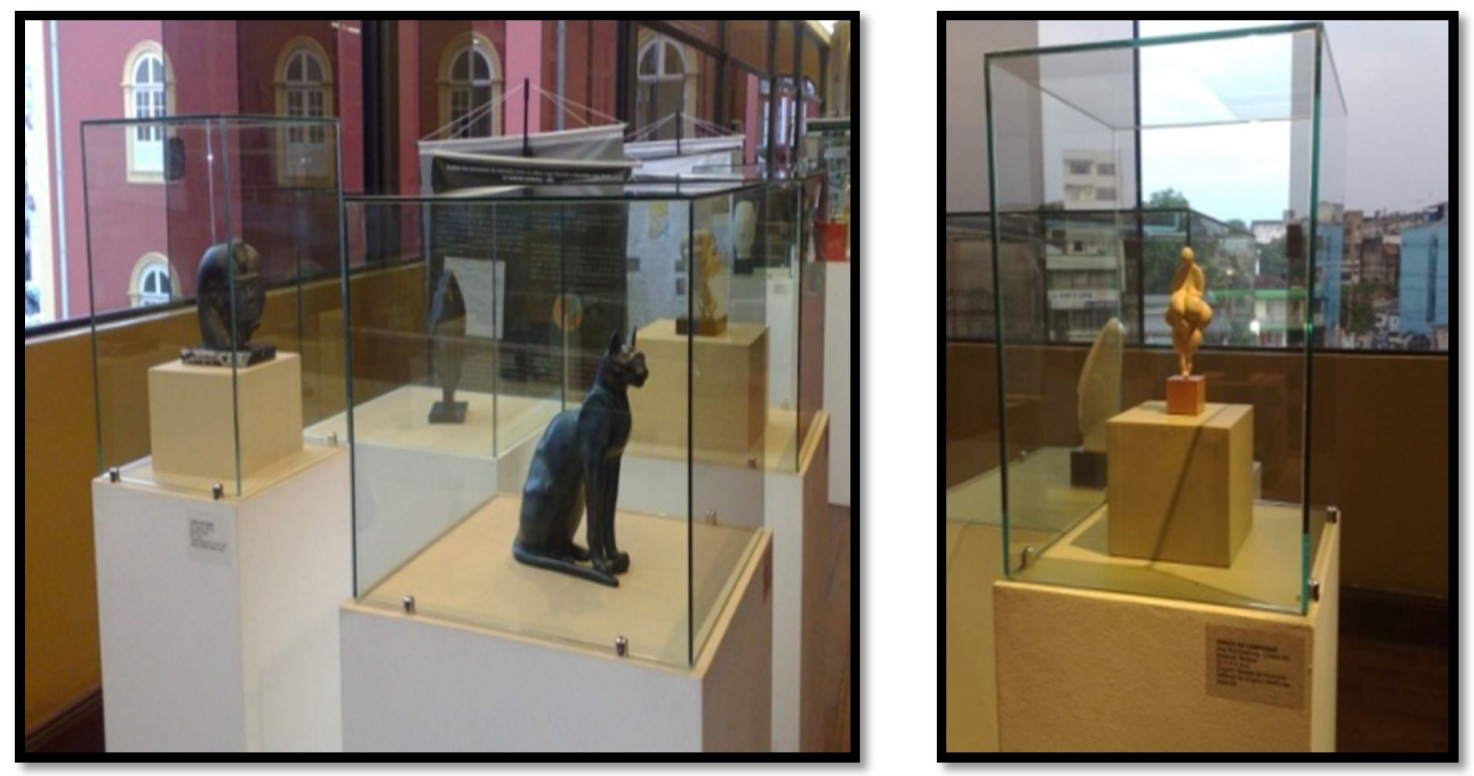

VENUS DE LESPUGUE

Arte Pré-histórica - 21000 AC Material: Resina

$23 \times 4 \times 4 \mathrm{~cm}$

Origem: Musée de l'Homme

Material de origem: Marfin de

Mamute

llustração IV.20: Réplicas variadas expostas no Palacete Provincial em Manaus. Réplicas diversas (acima à esquerda), Vênus de Lespugue (acima à direita) e etiqueta informativa, com dados sobre a réplica (à esquerda) (FotografiAs: Adriana Guimarães, 2010). 
O Encaminhamento da proposta de CRiação do Centro de Artesanato e Réplicas.

Inicialmente, a escolha do Lago do Limão não foi pautada em nenhuma particularidade local. Embora a comunidade tenha sítios arqueológicos já pesquisados, eles não foram o fator motivador para o desenvolvimento de alguma proposta no âmbito deste trabalho. Como integrante do PAC, o que norteou a escolha do Lago do Limão foi acompanhar o processo de promessas em relação à construção do CABA (Capítulo III) e, consequentemente, toda esperança depositada pela comunidade local e, em seguida, a suspensão da iniciativa sem que maiores detalhes fossem dados à mesma. Além disso, alguns ajudantes de campo que participaram intensamente de muitas escavações do PAC eram moradores do Lago do Limão.

A primeira reunião com a comunidade do Lago do Limão ocorreu no dia 15 de setembro de 2008, na escola municipal. Nessa ocasião, a conversa centrou-se na apresentação desta tese, que estava se iniciando, e na tentativa de debater com a comunidade propostas para o local. Muitos moradores compareceram, inclusive um vereador do município. No entanto, não houve muita manifestação por parte dos moradores sobre os rumos que o trabalho pudesse tomar na comunidade, embora eles se mostrassem interessados a se envolver em outra proposta que pudesse surgir. A grande quantidade de presentes deixou clara a insatisfação dos mesmos em relação aos acontecimentos sobre o CABA, assunto que era, de fato, o que os trouxe até ali (Ilustração IV.21).

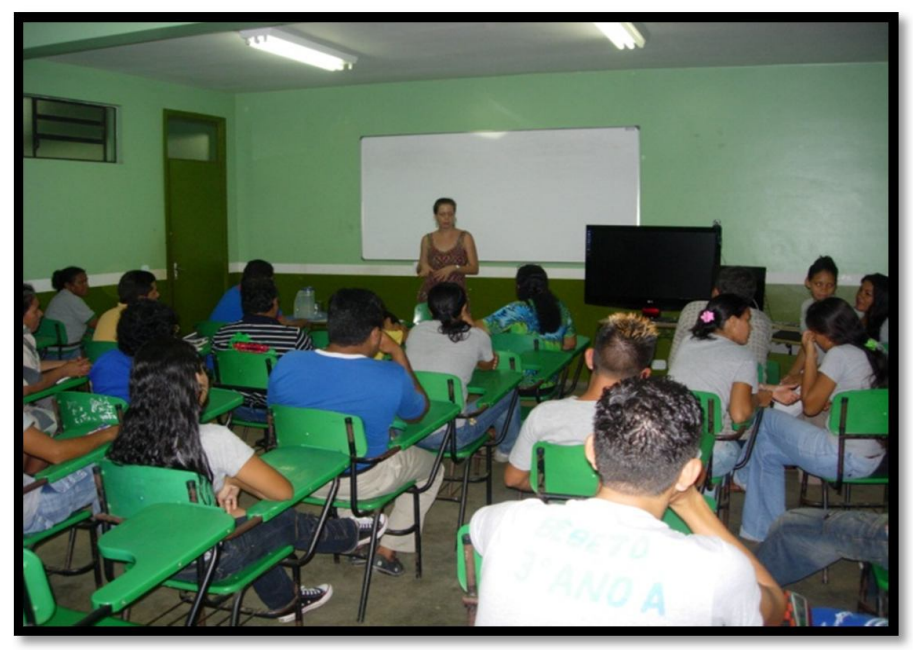

Ilustração IV.21: Primeira reunião no Lago do Limão. 2008. 
A ideia de implantar, no Limão, um centro de produção de artesanato com temática voltada à arqueologia foi apresentada e parece ter sido bem recebida. O diálogo com a comunidade aconteceu, no entanto, de forma muito vagarosa, com muita desconfiança em relação à presença da pesquisadora e, ao mesmo tempo, com a adoção de uma postura muito passiva, como se a iniciativa devesse estar previamente elaborada para que a comunidade então se envolvesse.

Conversas com o professor Dr. Luiz Anelli fizeram com que a ideia inicial de um Centro de Artesanato fosse expandida para um Centro de Artesanato e Réplicas. Criador e coordenador da Oficina de Réplicas ${ }^{98}$, Anelli explicou que a Oficina possui uma coleção de réplicas de fósseis e consegue manter-se economicamente com a venda de coleções didáticas a escolas de segundo grau e universidades. Segundo ele, o resultado do esforço mostra-se altamente satisfatório, com toda a produção sendo vendida. Em março de 2009, a Oficina só aceitava encomendas para o final daquele mesmo ano, situação que demonstrava claramente a importância do trabalho realizado e sua aceitação no mercado.

Etapas para a Criação do Centro de Artesanato e Réplicas.

1. Diagnóstico da realidade local

- Inventário turístico da Comunidade;

- Diagnóstico de materiais e técnicas já conhecidos pela comunidade que poderão ser utilizados nas Oficinas de Artesanato;

- Identificação de moradores que realizam algum tipo de trabalho manual;

- Análise das instalações da Associação Comunitária já existentes, tendo em vista a possibilidade de implantação do Centro de Artesanato e Réplicas no mesmo local, ou construção de um espaço para implantação do Centro.

2. Curso Inicial (Turismo e Arqueologia no Amazonas)

\footnotetext{
${ }^{98}$ Experiência ligada ao Museu de Geociências e ao Laboratório de Paleontologia Sistemática do Departamento de Geologia Sedimentar e Ambiental da USP (IGC/USP). Fonte: Oficina de Réplicas. Endereço: http://www2.igc.usp.br/replicas. Último acesso em: 03/2009.
} 
O O curso inicial tem como objetivo principal difundir informações sobre Turismo e sobre Arqueologia, apresentando conceitos e resultados de pesquisas. Especificamente, objetivava:

- A compreensão, por parte da comunidade, da importância do patrimônio arqueológico;

- O estímulo para a preservação do patrimônio arqueológico comunitário;

- A visualização da possibilidade de trabalhar o patrimônio arqueológico como um atrativo turístico.

- Formato: aulas teóricas, durante as quais serão elaborados produtos pelos participantes. Duração do curso: 15 horas/aula.

\section{Oficinas de Artesanato}

- As Oficinas contarão com aulas teóricas e práticas e com a presença de um designer e de um arqueólogo. Estes profissionais precisarão trabalhar em conjunto com os moradores na concepção dos produtos. Deverão ser analisadas soluções locais para embalagem das peças.

Duração: 40 horas/aula por técnica artesanal.

\section{Oficina de Réplicas}

- Serão ministradas aulas iniciais teóricas e, em seguida, aulas práticas, num total de 15 dias de atividades. Inicialmente deverá ser feita, por um arqueólogo, uma relação preliminar do que deve compor cada kit pretendido, bem como os textos que acompanharão necessariamente cada objeto replicado. Deverão ser analisadas soluções locais para embalagem das peças.

A metodologia foi pensada em etapas distintas (Curso, Oficina de Artesanato e Oficina de Réplicas). No entanto, espera-se que tanto os participantes da Oficina de Artesanato, quanto da Oficina de Réplicas, tenham passado necessariamente pelo Curso Inicial.

Diante da ausência de recursos financeiros para o cumprimento de todas as etapas necessárias para a criação do Centro de Artesanato e Réplicas, decidiu-se realizar o Curso Inicial Turismo e Arqueologia na comunidade, mesmo sem cumprir a etapa de Diagnóstico, 
que poderia ser realizada em outra oportunidade. O Curso era considerado importante para aprofundar o relacionamento dos pesquisadores com a comunidade, necessitava de poucos recursos e, principalmente, precisava ser testado para que pudesse ser aprimorado.

Durante os trabalhos de campo, em Julho de 2009, houve uma primeira tentativa de ministrar o curso Turismo e Arqueologia no Lago do Limão, em paralelo às atividades do sítio-escola da UEA, que ocorriam na comunidade naquele ano. Foram feitos os contatos iniciais com a Sra. Rosilene (gestora da escola municipal) e acertados horários e datas para o início do curso. Entretanto, durante a divulgação do mesmo, por problemas de saúde, que resultaram em hospitalização de quatro dias em Manaus e retorno para São Paulo, o curso teve que ser cancelado. No mesmo dia em que foram abertas as inscrições, todas as 30 vagas disponibilizadas já haviam sido preenchidas.

Nova tentativa foi feita entre janeiro e fevereiro de 2010 (de 31/01 a 13/02). O curso foi agendado para sete (07) dias, apenas duas horas por dia, das 16 às 18 horas. Esse formato foi decidido em conjunto com moradores locais que apontaram alguns fatores que poderiam ser empecilhos à participação das pessoas, como horário de trabalho, cansaço dos que trabalham na roça, família etc.

No primeiro dia de aula, estiveram presentes vinte e três (23) pessoas. No segundo dia compareceram apenas quinze (15) e do terceiro dia em diante a média foi de apenas treze (13) participantes. Os participantes alegaram que isso é frequente na comunidade e que a ausência de um certificado oficial para o curso era fator preponderante. Em comum acordo com os presentes, ficou decidido ampliar o tempo das aulas e, dessa forma, encerrar o curso antes do prazo.

Formato do Curso Turismo e Arqueologia no Amazonas - Conteúdo Programático

O curso foi pensado para ser ministrado a partir de slides em Power Point. Para garantir a execução do mesmo, adquiriu-se um projetor com capacidade de projeção equivalente ao de uma TV de 40". A opção por esse tipo de apresentação pautou-se na provável 
heterogeneidade escolar da turma que participaria do curso. Assim, a prioridade foi dada muito mais às ilustrações e informações orais do que a textos e informações escritas.

\section{1a parte:}

\section{- Patrimônio Cultural}

O O que é cultura?

- Patrimônio Cultural mundial.

○ Patrimônio Cultural brasileiro.

○ Órgãos responsáveis pela promoção da cultura, pela gestão do patrimônio e áreas afins: IPHAN, Secretarias Estaduais e Municipais (Educação - Cultura Lazer - Turismo), MTur, AMAZONASTUR.

Atividades práticas:

- Debates: diferenças culturais entre a comunidade e o mundo (a partir das fotos) e entre a comunidade e o resto do país (a partir dos materiais turísticos); - Mapa de atrativos culturais - montar um mapa localizando o que eles percebem como patrimônio cultural do seu entorno. Classificar os mais interessantes para serem visitados.

\section{- Arqueologia}

O que é arqueologia?

- Pesquisas arqueológicas - como são realizadas, objetivos e resultados.

○ Patrimônio arqueológico brasileiro.

- Arqueologia na Amazônia.

- O que fazer quando encontrar um sítio arqueológico ou vestígios arqueológicos?

Atividade prática: mapa arqueológico - montar um mapa localizando sítios arqueológicos e pessoas que possuem objetos arqueológicos. Classificar os mais interessantes para serem visitados. 
2a parte:

- Turismo

- Noções básicas sobre turismo

- Turismo no Brasil /Tipos de turismo

- Atrativo turístico

- Desenvolvimento Sustentável / Impactos do turismo / Capacidade de Carga

○ Produto turístico

- Qualidade / Atendimento / Preço

Atividade prática: analisar os mapas já elaborados e uni-los como um mapa de atrativos turísticos da comunidade. Inserir novos atrativos, ligados à cultura ou não. Classificar os mais interessantes para serem visitados.

\section{- Turismo Arqueológico}

○ Exemplos mundiais

- Exemplos nacionais

- Como trabalhar o Turismo Arqueológico?

- Interpretação do Patrimônio Cultural.

Atividades práticas:

- Rever o mapa de atrativos turísticos e ver se há algo novo em termos de Turismo Arqueológico.

- Por grupos, encenação de uma apresentação de um produto da comunidade para o turista.

Os resultados obtidos com o desenho dos mapas ajudam na compreensão do cenário da Comunidade do Lago do Limão, principalmente, no reconhecimento dos recursos naturais e culturais que podem ser transformados em atrativos turísticos, servindo de base para um Inventário Turístico.

Durante o desenho dos mapas (Ilustração IV.22), além de terem sido marcadas as áreas onde se situam o que os participantes classificaram como patrimônio cultural e arqueológico 
da comunidade, foram listadas outras atividades, percebidas como potencialmente turísticas, tais quais: trilhas pela mata durante a seca, passeios de barcos, pesca de piranha, focagem de jacaré (esses principalmente durante o período seco, que vai de setembro a janeiro), observação de fauna, colheita do açaí (fevereiro a maio) e a fabricação de farinha.
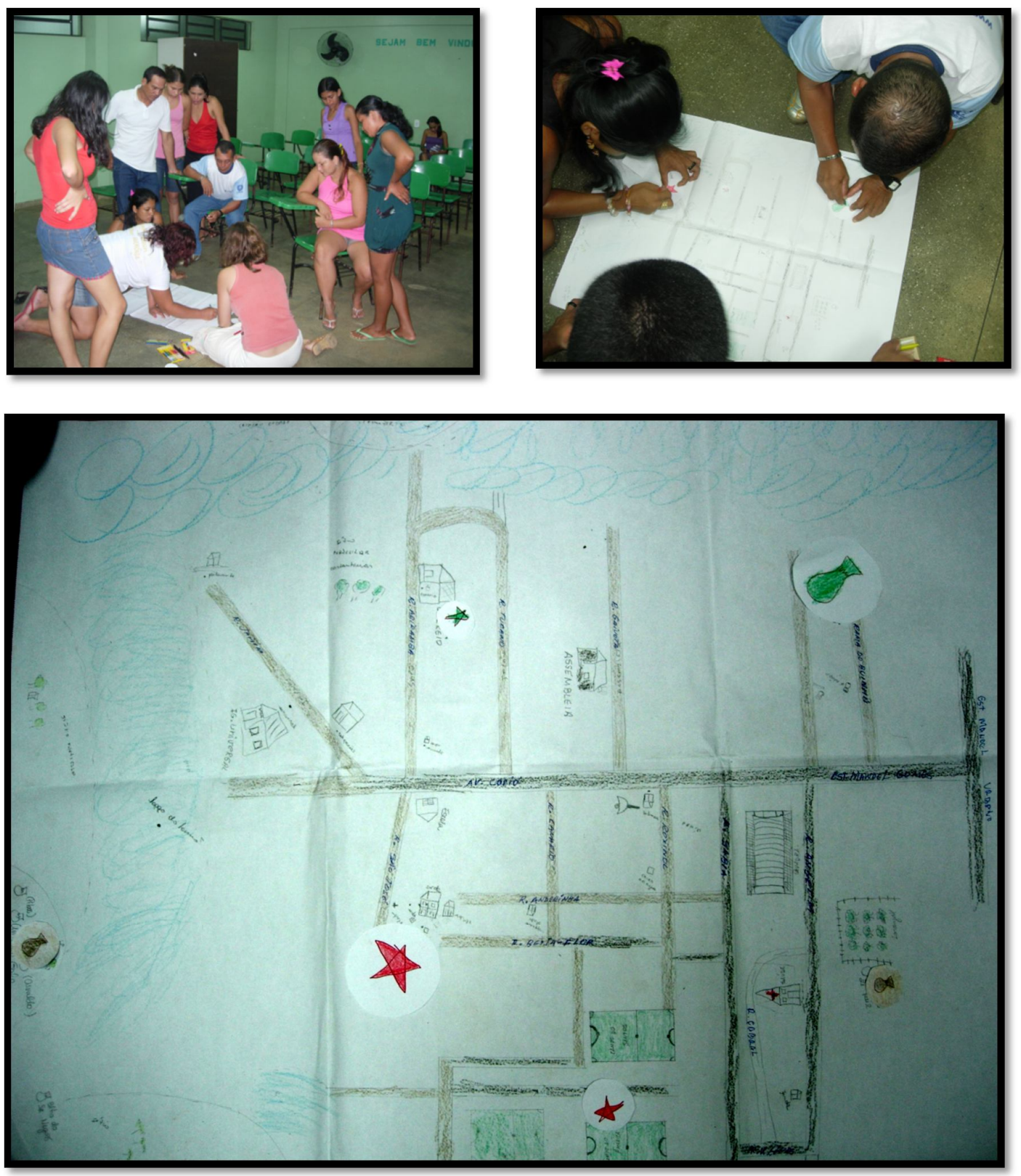

Ilustração IV.22: Desenho dos mapas e classificação dos atrativos mais significativos (FotogRAFIA: Leandro Braga, 2010). 
Entre os atrativos culturais locais foram marcados a capela local (o prédio ou um dos prédios mais antigos da comunidade, localizado num ponto alto, com vista para o Lago do Limão), os campos de futebol (devido aos torneios que acontecem todos os domingos) e a loja da Associação Comunitária (que produz artesanatos com sementes de Açaí, como colares).

Entre os sítios arqueológicos, foram marcados os que estão próximos à estrada de acesso a comunidade, entre os ramais da Paloma e Buinhú (sítio Lago do Limão), e os que se encontram na margem oposta do Lago do Limão, de frente à vila (Pilão, Antônio Galo e Osvaldo).

De maneira geral, a forma de apresentação dos conteúdos mostrou-se acertada já que conseguia obter a participação dos alunos nas principais atividades. No entanto, em geral, os alunos mostravam-se tímidos e a atividade de encenação, por exemplo, não foi realizada por falta de motivação do grupo. É possível que isso tenha ligação com o pouco tempo de relacionamento entre alunos e professora. Contudo, analisa-se que o fato de o Curso estar sendo realizado descontextualizado da implantação do Centro de Artesanato fez com o mesmo "perdesse o sentido" para os participantes já que não havia perspectivas de utilização do conhecimento que estava sendo recebido naquele momento. Estima-se que a realização do Curso, alinhada com as etapas seguintes para a implantação do Centro de Artesanato e Réplicas, seja mais proveitosa, inclusive para os comunitários que não pretendam trabalhar diretamente com a produção de souvenirs e réplicas, devido às outras oportunidades geradas com a implantação e funcionamento do Centro na comunidade.

O presidente da comunidade do Lago do Limão, Sr. Milton, sabendo da elaboração dos mapas no curso, resolveu contribuir desenhando com sua esposa um mapa da comunidade e outro com o conjunto de lagos e igarapés do entorno do Lago do Limão (Anexo 05 e 06).

IMPACTOS ESPERADOS COM A IMPLANTAÇÃO dO CENTRO DE ARTESANATO E RÉPLICAS NO LAGO dO LIMÃO.

Apesar da dificuldade na medição dos impactos gerados pelo turismo, já que o produto turístico é afetado por, e afeta diretamente, muitos outros setores da economia, na bibliografia especializada são citados como impactos econômicos do turismo e seus 
respectivos desdobramentos os seguintes itens: a geração de emprego e renda, a geração de divisas e a revitalização da atividade econômica/estímulo à atividade empresarial. É justamente isso que se espera como repercussão da implantação do Centro. Além disso, espera-se também que a renda gerada pela produção, que se converte em atrativo turístico ${ }^{99}$, possa ajudar a comunidade a empreender diversos outros negócios (recepção, alimentação, hospedagem, monitoria etc.).

Existem estimativas de que, para cada emprego direto gerado pelo turismo, 5,5 (cinco e meio) empregos teriam sido criados no total. Consequentemente, a renda gerada diretamente também se multiplica, dinamizando a economia local, inclusive através do incremento das receitas públicas decorrente do aumento da arrecadação tributária.

Somente para exemplificar como a produção artesanal pode trazer benefícios econômicos e estimular a atividade turística, cita-se uma pesquisa realizada no próprio município de Iranduba por Maria Domingas Silva, em trabalho apresentado para a conclusão do curso de Turismo pela Universidade do Estado do Amazonas (UEA). A estudante analisou "O turismo como indutor de desenvolvimento para a comunidade de Janauari, município de Iranduba, Amazonas" (SILVA, 2007) e concluiu que a economia local gira em torno da atividade turística (com artesanato, passeio de barcos, trilhas etc.), chegando a responder por $80 \%$ do giro econômico. A fabricação de artesanato (colares, pulseiras e brincos de sementes típicas) é o mote principal, empregando praticamente todas as pessoas da comunidade, na forma de artesãos, fornecedores de matérias primas ou vendedores. Silva (2007) calcula que cerca de 4.000 (quatro mil) turistas chegam à comunidade por mês, devido ao roteiro turístico "Encontro das Águas", vendido por muitas agências de receptivo baseadas em Manaus. Outro dado interessante apresentado diz respeito à forte presença feminina (80\%) no mercado de trabalho gerado com a produção e venda de artesanato. Segundo a estudante, o lucro obtido com a venda do artesanato chega a ser de até cinco (05) salários mínimos por mês para mais da metade dos entrevistados.

Esses dados indicam que a experiência dessa comunidade com o turismo pode ser replicada em outras comunidades do município de Iranduba e que dará aos envolvidos, certamente,

\footnotetext{
${ }^{99}$ Um bom exemplo do que está sendo dito acontece em Murano, na Itália. O local consegue atrair boa parte dos turistas que visitam Veneza graças à sua produção de cristais. São dezenas de lojas, muitas com produção aberta ao público, a qual se torna, em si própria, um espetáculo à parte.
} 
uma nova perspectiva de vida, modificando, para melhor, a situação socioeconômica local. Além disso, esta atividade poderá se tornar, obviamente, mais uma opção de visita para os turistas hospedados em Manaus, injetando renda nas agências de turismo locais e aumentando a permanência de turistas naquela cidade.

\section{OUtRAS Considerações SOBRE A PROPOSTA DE CRIAÇÃo do CENTRO dE ARTESANATO E RÉPLICAS.}

Como não existem no Brasil iniciativas similares de produção de materiais didáticos voltados à ciência arqueológica em grande escala, estima-se que a implantação do Centro de Artesanato e Réplicas poderia promover um grande impacto educacional no país, contribuindo com a disseminação de informações sobre a ciência arqueológica numa escala ainda não testada. A venda de kits com réplicas arqueológicas possibilita que escolas de todo o país tenham acesso a materiais elucidativos sobre a arqueologia brasileira, facilitando o ensino e aprendizado da disciplina.

Além disso, a produção local de kits e materiais científicos pode contribuir com a captação de novos materiais didáticos para a região do projeto, através do sistema de trocas e parcerias entre instituições com experiências parecidas, promovendo, assim, uma injeção de cultura em toda região.

Em conjunto com os materiais didáticos que deverão acompanhar cada coleção e aliadas ao interesse pessoal, as réplicas são capazes de estimular o pensamento de pessoas de todas as idades como nenhum outro objeto didático utilizado para estes fins é capaz de fazer. Com seu uso, professores poderão incrementar o ensino da arqueologia brasileira e dos costumes e origens de nossas culturas indígenas, demonstrando o uso de alguns instrumentos ou explicando a diversidade cultural dos antigos habitantes do território nacional.

Inicialmente essa proposta foi encaminhada à AMAZONASTUR, mas não foi obtida nenhuma resposta.

Em 2010, a mesma proposta disputou o Prêmio Santander de Empreendedorismo, sob orientação do professor Dr. Luiz Anelli, na categoria Empreendedorismo - Produtos e Serviços, concorrendo a uma premiação de $\mathrm{R} \$ 50.000,00$ a serem investidos na abertura do 
negócio. Para essa participação, o projeto foi ajustado e encaminhado sob o título "Réplicas Arqueológicas". Foi aprovado na primeira etapa de seleção, mas não passou na segunda etapa.

Em 2011, a proposta foi encaminhada, também, a um grupo de vereadores do município de Manaus para que pertinência de seu encaminhamento fosse analisada, como parte dos projetos de geração de renda para o entorno daquela capital. Ainda não houve respostas nesse sentido.

Em 2011, o MTur lançou o Manual para o Desenvolvimento e a Integração de Atividade Turísticas - Produção Associada ao Turismo (BRASIL, 2011) "ressaltando a importância de se agregar valor às atividades turísticas por meio da produção associada ao turismo". Produção associada é definida pelo MTUR como:

Qualquer produção artesanal, industrial ou agropecuária que detenha atributos naturais e/ou culturais de uma determinada localidade ou região, capazes de agregar valor ao produto turístico. São as riquezas, os valores, os sabores brasileiros. É o design, o estilismo, a tecnologia: o moderno e o tradicional. É ressaltar o diferencial do produto turístico para incrementar sua competitividade.

A publicação desse material demostra que esta proposta está em consonância com discursos atuais. Espera-se que ela ajude não apenas Iranduba ou o estado do Amazonas, mas, também, tantas outras localidades onde o patrimônio arqueológico já é conhecido, a inserilo no mercado de forma rentável e, principalmente, sustentável, em substituição às práticas atuais indesejadas que ainda persistem pelo país. 


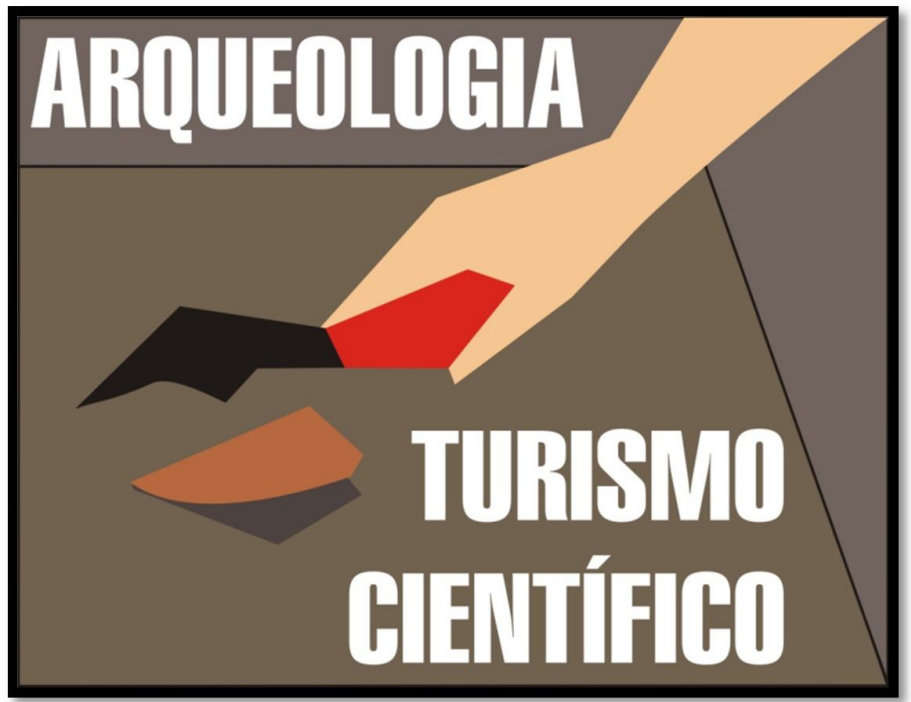

Ilustração IV.23: Logo para atividades de Turismo Científico (ARTE: Gustavo Accacio).

IV.2.4. A Construção de UM CONHECIMENTO - TURISMo Científico.

O Turismo Científico é uma atividade que propõe interação entre o turista e atividades ligadas à ciência, como observação de pássaros, estudos do meio, acompanhamento de profissionais em suas atividades de campo, entre outras. Desse modo, é uma atividade que possui muitas particularidades, dentre as quais se destaca o fato de requerer sempre a participação efetiva do profissional da área em questão. No caso da arqueologia, a presença de um arqueólogo responsável pela escavação e de sua equipe de trabalho.

Esse tipo de turismo ainda é pouco difundido no país, mesmo em outras áreas de conhecimento (a biologia, por exemplo), embora onde esteja ocorrendo esteja se mostrando bastante viável (como as iniciativas no projeto TAMAR, na Reserva Sustentável Mamirauá, e outras experiências no Pantanal, cf. blog Turismo Científico). Diferencia-se de atividades de voluntariado, por pressupor o pagamento pelos serviços envolvidos.

A proposta de Turismo Científico foi pensada como um ponto facilitador na demonstração do presente do município, que pode encontrar na arqueologia uma maneira de reescrever sua história. A maneira como se constrói esse conhecimento foi o tema escolhido para essa 
ação, que objetiva proporcionar o contato direto dos interessados com as pesquisas arqueológicas e, portanto, com a geração do conhecimento científico fundamental para proporcionar a releitura do passado e o redirecionamento dos atos do presente.

EnCAMInhamento da Proposta de TURISMo Científico

Excepcionalmente, essa proposta foi testada fora do município de Iranduba, já que não havia perspectivas concretas de realização de novos sítios-escolas no município, devido ao encerramento das atividades do PAC.

Em 2010, surgiu a possibilidade de trabalho no município de Silves, durante o sítio-escola do curso de Tecnologia em Arqueologia da UEA. O sítio-escola ocorreria no âmbito dos projetos Baixo Amazonas e Arqueologia Regional e História Local no Baixo Urubu, coordenados pela arqueóloga Helena Lima, integrante do PAC e professora do curso da UEA.

O município de Silves tem o turismo como sua maior fonte de recursos. Localizado a cerca de 200 km de Manaus, com área de $3.747,2$ km², situa-se na confluência do Rio Urubu com o Lago Canaçari, região de lagos amazônicos, com abundância de peixes e de rica diversidade aquática (MARINO E KISIL, 2008). A população local, segundo o IBGE (CENSO 2010), é de 8.435 habitantes.

Quanto à arqueologia, a região foi pesquisada no âmbito do Programa Nacional de Pesquisas Arqueológicas da Bacia Amazônica (PRONAPABA) por uma equipe de arqueólogos estrangeiros e brasileiros, organizada a partir da área de arqueologia do Museu Paraense Emílio Goeldi. Ondemar Dias (1987) conta que, mesmo antes do início do PronAPABA, em 1970, Simões já se envolvia ativamente na pesquisa do médio Amazonas, desenvolvendo o Projeto Silves, no baixo curso do Rio Urubu e lago Silves. Na região, o padrão encontrado foi o mesmo já conhecido para muitos sítios amazônicos: a Terra Preta.

No Lago de Silves, à margem esquerda do médio Amazonas, formado pelo represamento natural da foz do rio Urubu e alimentado por diversos de seus afluentes, foram realizadas duas etapas de pesquisa, uma na margem norte do lago (1970) e a outra no paraná de Silves (1979). Dezenove sítios foram localizados e cinco fases foram definidas (fases Silves, Saracá, 
Iraci, Sanabani e Garbe), das quais Saracá e Iraci estariam ligadas à tradição regional Saracá. Essas não foram datadas por 14C, tendo sítios profundos de $80 \mathrm{~cm}$ e $50 \mathrm{~cm}$, respectivamente (SIMÕES E MACHADO, 1987). Contudo, apesar da contribuição importante dos trabalhos de Simões, eles ainda não foram suficientes para o entendimento do cenário arqueológico local. As principais críticas aos seus trabalhos foram, de algum modo, as mesmas recebidas pelo trabalho dos pronapianos: a ânsia pela definição de fases, que resultou numa imensidão de nomenclaturas que até hoje permanecem sem muito significado e, também, na falta de documentação primária que possa ser acessada pelos pesquisadores para análise. Assim, não se sabe, por exemplo, qual é a associação entre os contextos datados e os complexos cerâmicos, já que os trabalhos não são acompanhados por perfis estratigráficos. Da mesma maneira, não há informações precisas sobre a variabilidade na forma e densidade dos sítios arqueológicos, o que dificulta comparações com outras áreas.

Nesse contexto, Helena Lima iniciou os projetos anteriormente citados para expandir os conhecimentos arqueológicos. O sítio-escola seria, portanto, uma etapa importante dos mesmos.

Em fevereiro de 2010, houve uma visita a Silves para conversas com o prefeito e alguns secretários do município (p. ex., os secretários da educação, da cultura e do turismo) para organizar e viabilizar as ações pretendidas no âmbito destes projetos: uma oficina de EP, em março, a cargo de Helena Lima e Tereza Parente, e o sítio-escola, em julho do mesmo ano.

Nessa primeira ida a Silves, a hospedagem do grupo deu-se na pousada Aldeias dos Lagos. Salienta-se que a construção dessa pousada transformou o município de Silves em referência em Ecoturismo no Brasil. Com apenas 12 habitações, esse empreendimento visa sustentabilidade nas atividades turísticas e o gerenciamento em parceria com os comunitários (LUÍNDIA, 2007). Alguns estudos apontam que, embora o turismo praticado pela pousada realmente seja bastante diferenciado do da maioria dos empreendimentos de selva do Amazonas, opondo-se à simples exploração dos recursos naturais, ele ainda não deveria ser classificado como sustentável (MoncAYo e RIBEIRO, 2005).

Independente disso, a forma de organização dos comunitários, através da Cooperativa de Turismo de Silves (COOPTUR), representa um trabalho de envolvimento comunitário pioneiro no Brasil. Ele serviu de base para uma nova visão de turismo, o Turismo de Base Comunitária 
(TBC), que vem sendo amplamente difundido há alguns anos, especialmente desde 2009, com o primeiro edital do MTUR para financiamento de projetos desse tipo.

Em reunião com o presidente da COOPTUR, o Sr. Vicente Neves, como parte da negociação para viabilizar a permanência dos alunos da UEA na pousada durante o período do sítioescola, ofereceu-se, como contrapartida, a possibilidade de criação de roteiros turísticos para serem operados por eles durante o mês de trabalho de campo. Além disso, surgiu a ideia de realizar uma marcação de percurso e/ou trilhas que pudessem ser trabalhadas permanentemente após a finalização dos trabalhos.

O planejamento foi realizado visando cumprir as combinações feitas com a CoOPTUR. Porém, a experiência praticamente teve que ser suspensa por motivos de saúde. Para não deixar de realizar as atividades, a professora Helena Lima indicou uma estudante de turismo de Manaus, Gisele Felipe, em vias de se graduar, e com interesse em participar do sítio-escola, para tentar seguir com a proposta, sob a sua supervisão. Assim, todo material produzido foi enviado a estudante e vários contatos telefônicos e via e-mail foram feitos no intuito de prepará-la para a realização do trabalho.

Como a atividade que estava sendo proposta era uma novidade no contexto da arqueologia amazônica, era necessário criar um formato, colocá-lo em prática e analisar se ele era coerente ou não.

Assim, estimou-se que seria necessário seguir alguns passos fundamentais, que são:

- Preparar os guias de turismo e operadores locais,

- Preparar a equipe que estará em campo para a recepção desses turistas,

- Formatar os roteiros, estabelecer a duração, os custos e a divisão dos lucros,

- Promover os produtos,

- Assumir a responsabilidade pela informação das 'boas práticas' que devem ser adotadas pelos turistas durante as visitas,

- Tentar mensurar o índice de aceitação dos roteiros oferecidos de acordo com o índice de hospedagem no referido mês,

- Promover uma pesquisa de satisfação com os turistas que participarem das atividades. 
ROTEIROS

Considerando-se a realidade local, inicialmente foram pensados dois roteiros:

Opção A: Um dia de arqueólogo.

Esta opção de roteiro inclui a oportunidade do turista de acompanhar um dia inteiro de escavações arqueológicas, podendo participar de algumas etapas do trabalho, como a escavação em si e o peneiramento. O turista seria levado pelo guia, faria uma visita geral ao sítio (como na opção B) e depois se integraria ao trabalho em uma das equipes, cumprindo os horários juntamente com os demais integrantes do grupo.

Esta opção requer atenção por parte da equipe que está em campo. Se o turista for brasileiro, não há maiores dificuldades; se for estrangeiro, deve-se tentar encaixá-lo em uma equipe em que um dos pesquisadores fale a língua do mesmo ou outra, em comum, que permita a comunicação.

Sempre que possível, alguém da equipe de campo deverá se responsabilizar pelo acompanhamento do turista na equipe, reportando-se ao coordenador de unidade ou coordenação geral. Caso a procura por tal atividade seja grande, será necessário avaliar o número de turistas que poderão se integrar a cada equipe (sugestão: um turista/equipe).

Incluso na Opção A: transporte e alimentação.
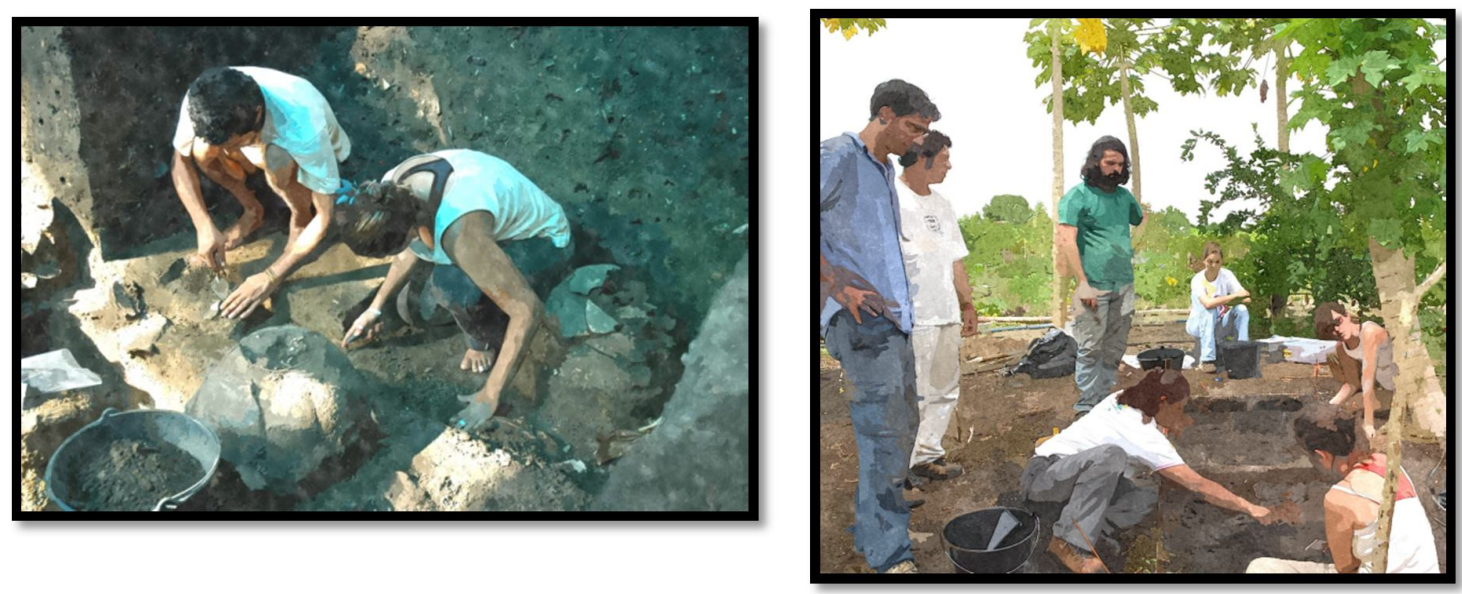

Ilustração IV.24: Ilustração artística de participação supervisionada em escavação arqueológica (Arte: Gustavo Accacio). 


\section{Opção B: Visita às escavações.}

Esta opção possibilita aos turistas a visita aos sítios arqueológicos que estejam sendo escavados no dia do passeio. Em cada parada, o turista receberia uma breve explicação do que está sendo escavado e quais as hipóteses iniciais que estavam sendo formuladas pelos arqueólogos.

O guia acompanharia o turista nesse roteiro, mas, nas paradas, seria necessário que a equipe de campo falasse brevemente sobre o trabalho na unidade, como já acontece com a EP.

Neste roteiro, o grupo poderá ser maior. A sugestão é de cerca de cinco (05) a dez (10) pessoas no máximo para evitar dispersão.

Incluso na Opção B: transporte e alimentação.
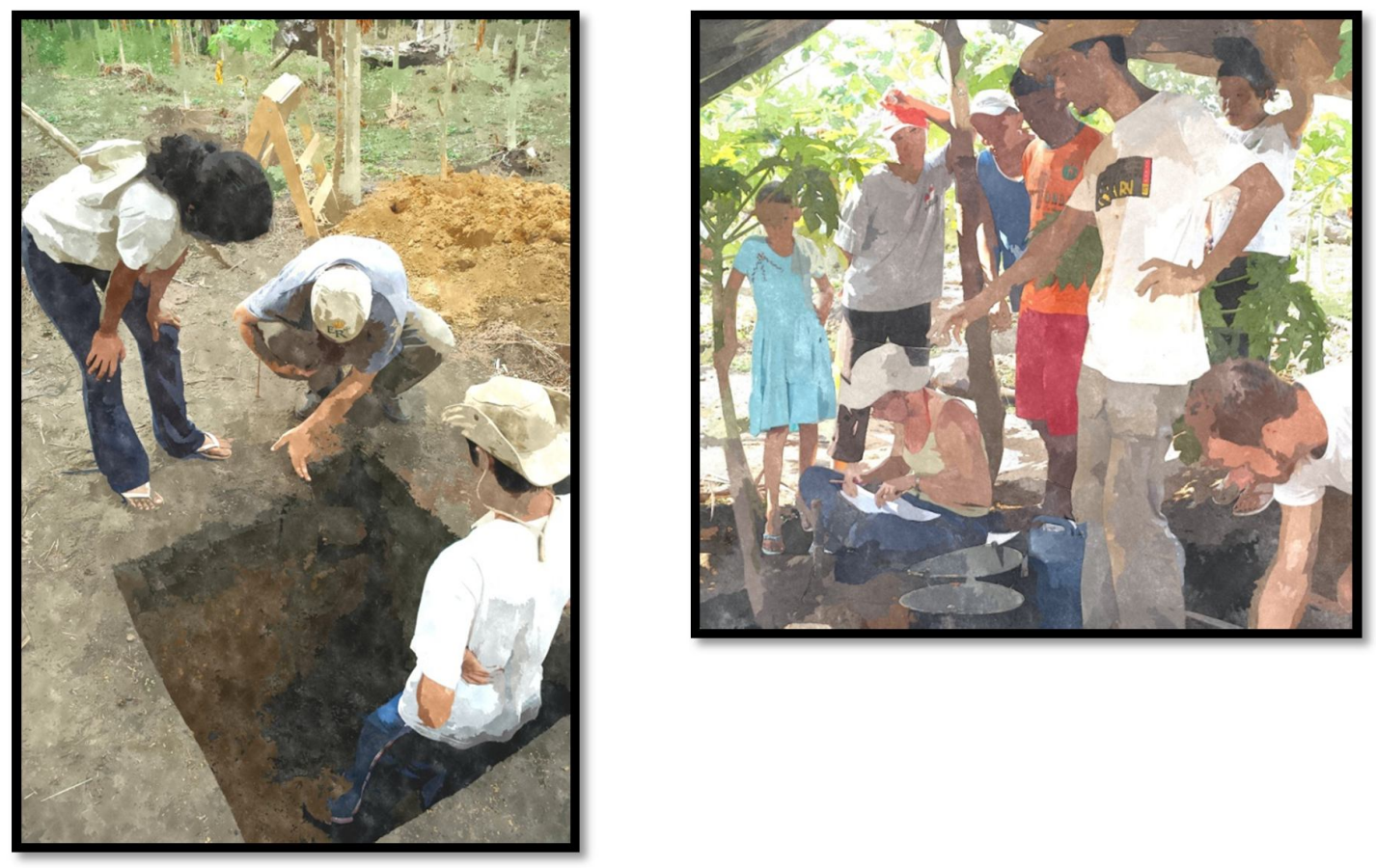

Ilustração IV.25: Ilustração artística de visitação turística a escavação arqueológica (Arte: Gustavo Accacio).

Esses foram os roteiros imaginados, mas indicou-se que essas opções deveriam ser rediscutidas com os comunitários, já que eles poderiam ter outras ideias ou sugestões. 
Tais opções não requerem muita estruturação, mas abrem caminho para uma ampla troca de informações entre arqueólogos, comunidades e turistas. Com essas ideias em mente, formulou-se um planejamento, que foi encaminhado para Gisele Felipe, para a avaliação da atividade de turismo científico no âmbito da arqueologia na Amazônia.

Planejamento para Realização de Atividades de Turismo Científico em Silves.

1. Curso Turismo e Arqueologia (já descrito no item IV.2.3)

- O quê?

- Curso formatado para os operadores/guias, neste caso, os próprios comunitários.

- Objetivo?

- Informá-los sobre a arqueologia e sobre as etapas de trabalho de campo

- Prepará-los para falar sobre as situações e os vestígios com os quais eles e os turistas estarão frente a frente.

○ Informá-los sobre o Turismo Arqueológico.

- Como?

- Conversar com o Sr. Vicente Neves para ver a melhor forma de convidar os comunitários. Tendo a Pousada Aldeia dos Lagos e a COOPTUR como parceiros, a decisão sobre a quem o curso poderia ser oferecido deveria ser avaliada em conjunto, sendo que o curso poderia ser destinado apenas aos associados ou ser aberto a outros guias de turismo locais.

- Sugestão: dar preferência àqueles que já trabalham como barqueiros, mateiros ou guias de turismo.

- Em qualquer um dos casos, pedir que a COOPTUR e a Pousada assumam a divulgação do curso e o convite aos participantes.

- Sugestão: estabelecer que só será autorizada visita às escavações arqueológicas a turistas que chegarem acompanhados por pessoas que concluírem o curso e estiverem cadastradas. 
- O curso poderá acontecer na própria pousada ou em outro local indicado pelos parceiros.

- Para esse curso, dever-se-ia contar com o auxílio de um profissional em arqueologia experiente e capacitado para esclarecer quaisquer dúvidas frente aos turistas presentes, pelo menos no dia em que se tratará especificamente sobre a arqueologia local e regional.

- No último dia do curso, decidir com os participantes o preço que será cobrado por cada um dos roteiros oferecidos e como será feita a divisão dos lucros entre eles.

- A sugestão nesse sentido é para que se estabeleça um valor total para a saída do barco (que cubra os custos totais e dê lucro aos oferecentes). Deste modo, o turista pode optar por ir sozinho, pagando o valor integral, ou ir num grupo, dividindo as despesas. Além disso, sugere-se que os oferentes dos roteiros possam decidir não só por um valor individual, mas também pela quantidade mínima de pessoas aceitas para a realização do passeio. Acredita-se que, por já trabalharem com outros roteiros, os oferentes tenham uma estimativa de quanto devem cobrar pelos roteiros. Também é necessário pensar sobre a possibilidade de descontos para comunitários interessados na visita.

- Importante: Decidir em conjunto com os participantes do curso a porcentagem sobre cada visita que deverá ser destinada à comunidade anfitriã (a ser entregue no final do mês ao presidente da comunidade, perante alguns comunitários).

- Outra decisão que precisa ser tomada é em quais locais os cartazes de divulgação poderão ser afixados na cidade e qual será a forma para o turista obter informações, reservar e realizar o pagamento. Será estabelecido apenas um local para o turista poder se informar melhor, reservar e pagar? Há algum outro local de confiança da comunidade onde isso possa ser feito (um posto de informação turística, por exemplo)? Se forem vários locais, como se pretende controlar quantos turistas vão realizar os passeios a cada dia? (Todas essas decisões devem partir dos alunos do curso, já que a operação 
será de sua responsabilidade. A equipe de arqueologia, entretanto, deverá ser comunicada sobre todas as decisões tomadas durante o curso).

- Quando?

- De preferência, o curso deverá acontecer logo na primeira semana de trabalho de campo.

- Material necessário:

- Slides preparados previamente, enviados para os ministrantes do curso em CD, passíveis de adaptação, caso os mesmos julguem necessário Data Show.

\section{Treinamento do pessoal em campo para a recepção dos turistas}

- O quê?

- Treinamento dos participantes do sítio-escola para as atividades de Turismo Arqueológico.

- Objetivo?

- Comunicar aos alunos e demais participantes do sítio-escola sobre as atividades de Turismo Arqueológico que ocorrerão paralelamente ao sítioescola. Esclarecer o que é Turismo Arqueológico, por que este trabalho está sendo realizado paralelamente ao sítio-escola e o quanto e como isso pode afetar as atividades normais em campo.

- Como?

- Uma palestra/conversa, podendo ou não ser apoiada por material audiovisual (Slides).

- Quando?

- No primeiro dia de campo, à noite, depois do jantar.

- Duração aproximada: uma (01) hora.

\section{Marcação do Percurso.}

- O quê?

- Marcação do percurso que será realizado com os turistas. 
- Objetivos?

- Definir quantas paradas serão permitidas, o tempo estimado para cada uma delas etc.

- Como?

- Visita ao campo com os comunitários que estiverem participando do Curso Turismo e Arqueologia e forem trabalhar nos roteiros.

- Observação do tempo despendido do porto até o sítio-escola.

- A partir da chegada ao local, iniciar a marcação do percurso, definindo por quais unidades os turistas passarão e quanto tempo poderão observar as atividades. Para isso, as equipes devem estar estabelecidas em campo, trabalhando normalmente.

- Verificação, em cada equipe, da presença de uma ou mais pessoas que falem outras línguas (inglês, espanhol, alemão etc.). Tais dados servirão de referência futura para priorizar aquela equipe/unidade caso o turista seja estrangeiro. Assim, para grupo com estrangeiros, a parada poderá ser maior naquela unidade.

- Nessa mesma oportunidade, apresentação dos participantes do Curso Turismo e Arqueologia a moradores do entorno direto das escavações, principalmente ao representante daquela pequena comunidade, se for o caso. Explicação do trabalho a ser realizado.

- Possível sugestão de que eles preparem água mineral, refrigerante, cervejas ou artesanato para oferecer aos visitantes, salientando-se, entretanto, que não se saberá exatamente qual será a procura pelos pacotes.

- Verificação junto à comunidade de entorno das escavações da existência de restrições em relação ao comportamento dos turistas durante a visita (o que pode ou não pode ser feito?). Qualquer comportamento não desejado, apontado por eles, deve ser comunicado aos turistas durante a palestra.

- Quando?

- Após o encerramento do Curso Turismo e Arqueologia, pela manhã. 


\section{Promoção dos Roteiros}

- O quê?

- Distribuição dos cartazes de divulgação em pontos estratégicos da cidade. Os locais devem ser escolhidos pelos participantes do curso.

- Objetivos?

- Promover/divulgar os roteiros.

- Como?

- Conversas com o proprietário de estabelecimentos comerciais onde os cartazes possam ser afixados; breve explicação sobre a atividade (roteiros de Turismo Científico), pedindo apoio à divulgação das atividades.

- Cada aluno 'formado' no curso e que vá atuar como guia deverá se responsabilizar pela colocação de alguns cartazes e pela conversa com os proprietários. Todos devem anotar o nome e o endereço dos locais onde os cartazes foram afixados para retorno na etapa de verificação.

- Quando?

- Após a 'formatura' dos guias. 


\section{Arqueologia na Amazônia Brasileira Archaeology in the Brazilian Amazon}

Durante o mês de Julho de 2010, o Museu Amazônico da Universidade Federal do

Amazonas, em conjunto com o curso superior de Tecnologia em Arqueologia da

Universidade do Estado do Amazonas, realizará escavações arqueológicas no municipio de Silves.

During the month of July 2010 the Amazon Museum Federal University of Amazonas,

with the college of Technology in Archaeology, University of Amazoras State, is doin

excavations in the town of Silves.

\section{Você quer visitar as escavaçóes? want to visit the excavations?}

Quer viver um dia de arqueólogo? Want to live one day as $n$ archaeologist?

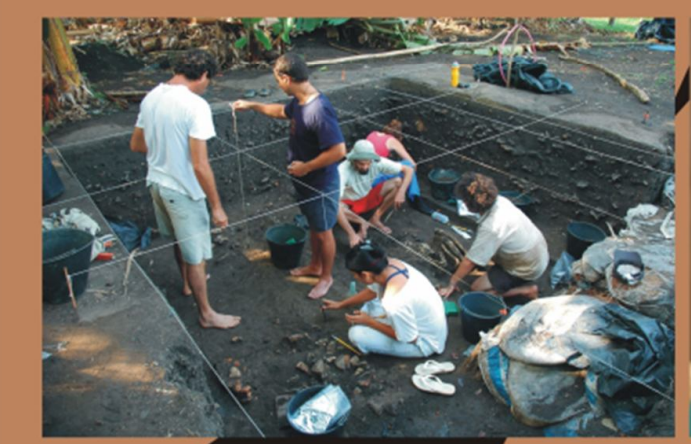

A COOPTUR é nossa parceira nessa iniciativa e seus associados foram treinados e credenciados para atuar como guias de turismo de forma a garahtir a sua satisfaçāo durante a visita e o bom andamento dos trabalhos. ThecOOPTUR is our partner in this initiation a

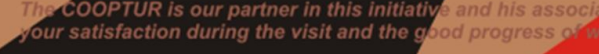

Informações disponiveis no(s) seguinte(s) local(is):

Telefone de contato:

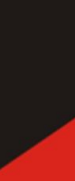

Projeto 'Aproveitamento Turístico do Patrimônio Arqueológico do Amazonas' Projeto 'Arqueologia Regional e História Local no Baixo Urubu'

Parcerias:

COOPTUR - Cooperativa de Trabalho Ecoturistico e Ambiental do Amazonas e Pousada Aldeia dos Lagos.

Apoio institucional:

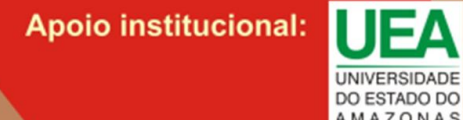

DO ESTADO DO

AMAZONAS
Museu
Amazoñ

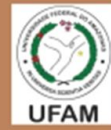

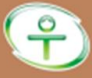

FAPEAM

Ilustração IV.25: Cartaz de divulgação dos roteiros (ARTE: Gustavo Accacio). 


\section{Palestra Inicial para os Turistas}

- O quê?

- Antes da realização do roteiro, convite aos turistas para assistirem a uma breve palestra com informações sobre o percurso a ser realizado.

- Objetivos?

- Apresentar aos turistas uma síntese dos trabalhos arqueológicos realizados na Amazônia brasileira;

- Contextualizar e justificar o trabalho que está ocorrendo naquele momento em campo;

- Informar sobre a postura que eles devem adotar em campo;

- Apresentar detalhadamente o roteiro que será seguido (percurso, duração, atividades etc.).

- Como?

- Sugestão: o formato pode ser o de uma conversa, mostrando fotografias etc. A conversa/palestra deve ser ministrada por uma pessoa da equipe de Turismo Arqueológico, de forma a garantir que as informações sejam realmente comunicadas. Entretanto, deve ser acompanhada pelo guia que irá acompanhar o turista durante o roteiro.

- Quando?

- A palestra com os turistas ocorrerá sempre na noite anterior à sua visita. Pode-se optar também por realizar a palestra antes da saída do passeio, marcando a saída para pelo menos 30 minutos antes do início programado.

\section{Pesquisa Antes e Depois}

- O quê?

- Pesquisa Antes e Depois com os turistas.

- Objetivos?

- Pesquisa Antes: avaliar o conhecimento pré-existente sobre o assunto e o que o atraiu a realizar o roteiro escolhido (Tabela IV.2). 
- Pesquisa Depois: avaliar o nível de satisfação dos mesmos com a visitação, colher críticas, sugestões ou elogios (Tabela IV.3).

- Como?

- Aplicar um questionário com questões fechadas e abertas.

- Quando?

- No momento em que os turistas estiverem reunidos para a palestra, passar a Pesquisa Antes. No retorno dos mesmos, aplicar a Pesquisa Depois.

TABELA IV.2:

Pesquisa 'Antes'

1. Para você, o que é arqueologia? For you, what is archeology?

2. Você já viu alguma escavação arqueológica antes? (sim) (não) Have you seen any archaeological excavation before? (yes) (no)

3. O que o atraiu a realizar esse passeio? What drew you to make this trip?

Obs. Utilize o verso da folha para fazer qualquer comentário/crítica/sugestão que julgar necessário.

Note. Use the back of the sheet to make any comment/criticism/suggestion that you think necessary.

TABELA IV.3:

Pesquisa 'Depois'

Avalie a sua satisfação com o passeio realizado, considerando sempre os seguintes critérios: Rate your satisfaction with the tour done, always considering the following criteria:

1 - nenhuma (no) 2 - pouca (low) 3 - média (average) 4 - grande (big) 5 - muito grande (very big)

Marque um $X$ no número correspondente à sua satisfação em relação aos seguintes itens: Mark an $X$ in the number corresponding to their satisfaction with the following items:

1. Trabalho realizado pelo guia que te atendeu: Work done by the guide that I met: (1) (2) (3) (4) (5)

2. Recepção da equipe em campo: Reception staff in the field: (1) (2) (3) (4) (5)

3. Atividades desenvolvidas (roteiro 1): Activities undertaken (Rout 1): (1) (2) (3) (4) (5)

4. Percurso realizado (roteiro 2): Way taken (Route 2): (1) (2) (3) (4) (5)

5. Aprendizado durante o passeio (ambos): Learning process during the tour (both): (1) (2) (3) (4) (5)

6. Você considerou o preço pago pelo passeio: Have you considered the price paid for the tour: (barato) (cheap) (adequado) (appropriate) (caro) (expensive)

Obs. Utilize o verso da folha para fazer qualquer comentário/crítica/sugestão que julgar necessário.

Note. Use the back of the sheet to make any comment/criticism/suggestion as it deems necessary. 


\section{Guia de ‘Boas Práticas’ para o Turismo.}

- O quê?

- Material em inglês original (AIA, s/d).

- Material elaborado com base no guia da AIA (s/d), único do tipo destinado exclusivamente ao Turismo Arqueológico, mas com ajustes à realidade brasileira, como a parte de legislação, e acréscimo dos princípios orientadores para o Turismo Arqueológico brasileiro (Item II.4 do Capítulo II).

- Objetivos?

- Transmitir informações que ajudem comunitários, equipe e turistas a entenderem melhor as 'boas práticas' que são desejadas na realização de viagens desse tipo.

- Como?

○ Oferecer o material para leitura e consulta.

- Quando?

- Disponibilizar o material de leitura e consulta na pousada ou alojamento do turista; entrega do mesmo ao guia de turismo no dia do passeio para que ele ofereça ao turista no barco. Apresentar o material informativo ao turista no dia da palestra. Apresentar o material aos participantes do Curso Turismo e Arqueologia, durante o mesmo, para leitura e consulta. Enfim, de todas as maneiras possíveis.

- Material:

- Envio prévio de duas ou três cópias impressas do material em português e uma do original em inglês à equipe que desenvolveria as atividades de Turismo Científico em Silves. 


\section{Avaliação Geral dos Trabalhos}

- O quê?

○ Avaliação geral dos trabalhos

- Objetivos?

- Avaliar o resultado alcançado com o trabalho, se seus objetivos foram atingidos.

- Como?

- Curso dos Guias:

- Verificação: aplicação de um questionário com os participantes (Tabela IV.4).

TABELA IV.4: Verificação Curso dos Guias

Avalie a sua satisfação com o curso Turismo e Arqueologia, considerando sempre os seguintes critérios:

\section{1-nenhuma 2-pouca 3-média 4-grande 5-muito grande}

Marque um X no número correspondente à sua satisfação em relação aos seguintes itens:

1. Ao material áudio visual (slides) utilizado: (1) (2) (3) (4) (5)

2. Ao conteúdo que foi ministrado: (1) (2) (3) (4) (5)

3. À importância dos assuntos tratados para a sua vida pessoal: (1) (2) (3) (4) (5)

4. À importância dos assuntos tratados para a sua vida profissional: (1) (2) (3) (4) (5)

5. Às atividades propostas: (1) (2) (3) (4) (5)

- Treinamento/Funcionamento dos trabalhos:

- Verificação: pesquisa de opinião com coordenadores de unidades e alguns participantes (Tabela IV.5). 
TABELA IV.5:

Verificação Treinamento da Equipe de Campo/ Funcionamento dos trabalhos

Avalie a sua satisfação com o treinamento da equipe de campo e com o funcionamento dos trabalhos, considerando sempre os seguintes critérios:

\section{1-nenhuma 2-pouca 3-média 4-grande 5-muito grande}

Marque um $X$ no número correspondente à sua satisfação em relação aos seguintes itens:

1. Clareza em relação aos objetivos do trabalho de turismo: (1) (2) (3) (4) (5)

2. Clareza em relação ao que é turismo científico e tur. arqueológico: (1) (2) (3) (4) (5)

3. Clareza em relação à interferência desse trabalho nas atividades de campo: (1) (2) (3) (4) (5)

4. Interferência concreta do trabalho nas atividades de campo: (1) (2) (3) (4) (5)

5. Percurso marcado/realizado: (1) (2) (3) (4) (5)

- Marcação de percurso:

- Verificação: questão 5 da verificação anterior.

- Promoção dos roteiros:

- Verificação:

A) Nos locais onde os cartazes foram afixados - sensação dos proprietários em relação ao impacto daquela propaganda (Tabela IV.6).

B) Em algumas pousadas da cidade - verificação da ocupação turística média durante o mês de Julho, para avaliar quantos turistas estiveram na cidade durante aquele período.

TABELA IV.6:

Verificação Promoção dos RoteiRos nos locais onde os cartazes foram afixados.

Qual a sua impressão em relação ao impacto da propaganda que foi realizada em seu estabelecimento?

1. Acha que chamou a atenção das pessoas? (sim) (não)

2. O que mais chamou a atenção? ( ) o assunto ( ) apenas as fotos ( ) outro:

3. Acredita que o cartaz possibilitou a venda de muitos pacotes? (sim) (não)

4. Que tipo de comentários as pessoas faziam quando viam o cartaz?

5. Acha que faltou alguma informação no cartaz? (sim) (não). Qual? 
TABELA IV.7:

Verificação Promoção dos Rotelros nas pousadas da cidade:

Nome do estabelecimento:

1. Quantos quartos o estabelecimento tem?

2. Quantos turistas estiveram hospedados durante o mês de Julho?

3. Soube dos trabalhos de escavação arqueológica que estavam sendo realizados no município? (sim) (não)

4. Como soube?

5. Soube que alguns roteiros turísticos estavam sendo trabalhados? (sim) (não)

6. Como soube?

7. Indicou os roteiros para os seus hóspedes? (sim) (não).

8. Por que indicou ou não indicou?

9. Um cartaz do trabalho foi afixado no estabelecimento? (sim) (não)

Em caso afirmativo, responder as próximas questões. Caso contrário, encerrar.

10. Acha que o cartaz chamou a atenção das pessoas? (sim) (não)

11. O que mais chamou a atenção? ( ) o assunto ( ) apenas as fotos ( ) outro:

12. Acredita que o cartaz possibilitou a venda de muitos pacotes? (sim) (não)

13. Que tipo de comentários as pessoas faziam quando viam o cartaz?

14. Acha que faltou alguma informação no cartaz? (sim) (não). Qual?

- Palestra com os turistas:

- Verificação: Pesquisa Depois.

- Quando?

- Todas as verificações devem ser feitas o mais próximo possível do encerramento dos trabalhos. 


\section{Considerações SOBRE o EnCAMINHAMENTO da PROPOSta de TuRISMo CientífICO}

Considera-se que o planejamento foi elaborado de forma consistente, preocupando-se em abranger todos os envolvidos nas atividades e em compartilhar responsabilidades. Mesmo assim, a experiência com o Turismo Científico não atingiu o potencial pretendido, com pouco do que foi proposto podendo ser realizado. Conforme o relatório de campo enviado por Gisele Felipe (ANEXo 07), o Curso Turismo e Arqueologia não foi ministrado aos comunitários, provavelmente devido à alta temporada turística. Porém, ao mesmo tempo, Gisele indica a baixa afluência de turistas na Pousada Aldeias do Lago no período do sítio-escola, somente quatro (04). Desse modo, não foram cumpridas também as etapas de divulgação e, consequentemente, as etapas de verificação das atividades.

Sem ter acompanhado de perto o encaminhamento dos trabalhos, fica realmente muito difícil avaliar os seus resultados. Deste modo, as análises seguintes baseiam-se no referido relatório. Percebe-se que houve incompreensão sobre o público a quem o Curso deveria ser direcionado: o relatório cita o fato de o curso ter sido oferecido não somente aos comunitários que já atuam como guias de turismo, de preferência da cidade de Silves, como foi sugerido na proposta inicial, mas também aos moradores do entorno imediato dos sítios. $\mathrm{Na}$ atividade de Turismo Científico, não caberia a participação daquela comunidade, do entorno imediato dos sítios escavados, nas atividades propostas já que isso requereria treinamentos e capacitações muito longos e específicos, tanto em relação ao trabalho com turistas (serviço de guia) quanto em relação à arqueologia, para utilização em um período muito curto de tempo e possivelmente em apenas uma oportunidade. A capacitação dos guias já atuantes na região em relação à arqueologia, por outro lado, é viável porque permite que, em qualquer oportunidade de escavações arqueológicas na região, o conhecimento seja útil. Devido a essa particularidade, conforme apontado no planejamento, uma porcentagem dos lucros deveria ser repassada às comunidades onde as escavações acontecem. Também é descrita, no relatório, a falta de interesse dos guias e dos membros da ASPAC, embora o convite e a divulgação tenham sido feitos a estes grupos. No entanto, Gisele não descreve, em seu relatório, a forma como essa divulgação foi realizada.

Segundo o mesmo relatório, para os turistas, "a divulgação do curso foi promovida de modo informal através de propaganda boca a boca e não com os cartazes enviados para a 
distribuição estratégica em pontos chave da cidade". Avalia-se que este procedimento possui um alcance bastante limitado e a divulgação é fator crucial para o desenvolvimento do tipo de experiência que estava sendo proposta. No entanto, sem a formação de uma turma de participantes do Curso Turismo e Arqueologia, a divulgação através dos cartazes estava, de fato, inviabilizada.

Além disso, através das descrições feitas no item 'Observações' do mesmo relatório, fica claro que o objetivo do trabalho que estava sendo proposto não foi completamente absorvido. Aparentemente, não ficou claro que se tratava de um teste de um modelo genérico (que se intencionava apto a ser replicado em qualquer local onde existisse a combinação 'escavações arqueológicas' $x$ 'existência de turistas') e não de uma proposição específica àquelas pequenas comunidades do município de Silves.

Através de conversas pessoais com integrantes da equipe de Educação Patrimonial, percebeu-se que a ausência da autora da proposta tenha sido fator decisivo, já que os integrantes do grupo não se sentiam à vontade para atuar no encaminhamento da atividade por não terem familiaridade com o assunto e/ou com a forma de trabalho.

De todo modo, nota-se que experiências de Turismo Científico, atreladas a trabalhos de campo de arqueologia, têm sido cada vez mais comuns em todo o mundo. Em muitos sites internacionais é possível encontrar relações de sítios-escolas de universidades bastante renomadas e/ou opções de visitas a sítios arqueológicos famosos, com acompanhamento de arqueólogos com reputação na área. Muitas dessas oportunidades são oferecidas tanto a estudantes de arqueologia quanto a de outros cursos, ou a pessoas apenas interessadas no assunto. Em quase todas as ofertas, são cobrados valores consideráveis para cobrir os custos da pessoa em campo e, em alguns casos, para contribuir com a pesquisa que está sendo realizada. Durante as buscas por atividades desse tipo, o Brasil sempre esteve ausente.

Embora se considere que esta seria uma etapa importante no plano interpretativo proposto para Iranduba, que justificaria o esforço de uma nova experimentação, a falta de perspectiva em relação à continuidade das pesquisas do PAC inviabilizaria iniciativas desse tipo. De todo modo, em caso de novas pesquisas sistemáticas na área, será sempre possível testá-la novamente ou buscar uma nova forma para viabilizar o Turismo Científico. 


\section{IV.3. Observações em Relação À inserÇão de Produtos Arqueoturísticos no Cenário Turístico Atual do MunicíPIo de IRANDUBa.}

A implantação de um plano interpretativo pode provocar grandes impactos socioeconômicos no município. Não se trata apenas dos impactos diretos causados por cada um dos produtos propostos e das pessoas envolvidas diretamente com eles, mas sim do necessário aporte de infraestrutura básica urbana e turística que permita a chegada e permanência dos turistas no destino. Fala-se, por exemplo, de novos investimentos em saneamento básico, melhoria do sistema de transporte público, estímulo à abertura de novas agências bancárias, bem como de farmácias, mercados, bares, restaurantes, lanchonetes, entre outros estabelecimentos comerciais que, em geral, ainda são em número muito pequeno no município. Fala-se, enfim, do que se conhece como o poder multiplicador do turismo (MOTA et al., $\mathrm{s} / \mathrm{d})$.

A proposta do Museu de Sítio Hatahara é, dentre todas as propostas apresentadas, a com menor poder de multiplicação dos benefícios ao que pode ser percebido como comunidade de entorno imediato, já que o terreno é uma propriedade particular e o equipamento é o que requer maior qualificação profissional das pessoas envolvidas. Porém, o bairro onde a propriedade está localizada cresceu devido a invasões, possuindo ainda hoje uma infraestrutura urbana bastante deficiente, fato que não deve ser desprezado na construção e funcionamento do Museu. No Anteprojeto, estimou-se a implantação de uma lanchonete dentro do prédio principal. Essa lanchonete poderia, por exemplo, priorizar a compra de produtos fabricados pela comunidade de entorno imediato do sítio, como salgados, bolos ou doces. Para isso, seria muito importante a realização de cursos profissionalizantes que poderiam ser viabilizados junto a universidades, ao SEBRAE, ou mesmo cursos particulares financiados pela Prefeitura. Além disso, com a afluência de público espontâneo à sede municipal, devido a presença do Museu de Sítio Arqueológico Hatahara, outras atividades ligadas indiretamente à atividade turística poderiam ser beneficiadas, como já explanado anteriormente (taxis, bares, restaurantes, hotéis e pousadas, agências bancárias, serviços de guias de turismo etc.). Mas, da mesma forma, para tal, a comunidade municipal como um todo precisaria estar preparada Em relação à comunidade de Paricatuba, o plano de 
interpretação da Vila e a sua preparação para a recepção dos turistas podem transformar a realidade socioeconômica local através da abertura de novas ocupações e da injeção de renda na economia, apresentando novas perspectivas de futuro para a comunidade. A interpretação do patrimônio da comunidade pode gerar desdobramentos diversos, desde a atuação de comunitários como intérpretes, à abertura de bares, restaurantes, sorveterias, lojas de artesanatos ou de venda dos produtos locais.

Na comunidade do Lago do Limão, a situação é bastante diferente das demais. Os sítios arqueológicos encontram-se mais distantes da vila. Não seria o caso de propor, para esse local, grandes investimentos em criação de um museu, por exemplo, o que seria injustificado. Essa vila, no entanto, possui particularidades que já a colocariam, naturalmente, em qualquer roteiro turístico da região: a sua localização privilegiada, com vistas belíssimas, a existência de uma associação produtora de artesanato com sementes locais, a produção de açaí e as festas a ele associadas. Além disso, a comunidade do Lago do Limão possui uma característica muito particular, que também deveria ser valorizada como atrativo turístico, que são os torneios de futebol aos domingos. Assistir a esses torneios é uma experiência única, que poderia agradar a turistas de qualquer lugar do mundo. Nestes torneios, jogam todos da comunidade: homens, mulheres e crianças, em um verdadeiro espetáculo comunitário que diverte e entretém o espectador, além de fazer jus à fama do Brasil de ser "o país do futebol", o que pode ser explorado enquanto atrativo turístico e cultural.

A falta de infraestrutura faz com que, embora os espaços selecionados sejam facilmente acessíveis, os visitantes não consigam permanecer por muito tempo no local e, consequentemente, não coloquem mais dinheiro em circulação. Isso gera problemas já bem conhecidos pelo município, como a chegada de visitantes acompanhados de guias de fora da comunidade, ou em grupos, que trazem tudo que precisam para os passeios e visitas (por ex., vindos de Manaus ou dos hotéis de selva do próprio município), causando impactos ambientais, como o lixo produzido durante a estadia, por exemplo. Esses problemas estruturais não poderão ser desprezados no caso de haver continuidade das ideias aqui apresentadas. Por outro lado, enfatiza-se que a criação dessa infraestrutura por si só não 
promove a acessibilidade aos sítios arqueológicos. Ela também pode gerar problemas de conservação desses locais, já que apenas facilitaria a chegada e permanência dos turistas, mas não proporcionaria reflexões sobre os locais visitados.

Com a análise da realidade municipal, outra consideração importante levantada foi a de que os atrativos arqueoturísticos deveriam integrar-se aos já tradicionais atrativos ecoturísticos, de forma a agregar valor aos produtos locais, através da possibilidade de conhecer parte do passado remoto da Amazônia. Essa interligação amplia o poder multiplicador do turismo e pressupõe mais viabilidade aos produtos arqueoturísticos propostos.

Nesse sentido, lembra-se que a região amazônica é promovida como um importante polo de Ecoturismo brasileiro e que os produtos regionais vem sendo divulgados com ênfase nesse segmento desde o Programa de Apoio ao Ecoturismo e à Sustentabilidade Ambiental do turismo (PROECOTUR), desenvolvido pelo Ministério do Meio Ambiente. Observa-se ainda que o perfil dos ecoturistas, sintetizado a partir da consulta a diversos conceitos da atividade ecoturística, sugere que estes estão conscientes dos problemas socioambientais da atualidade, querem estar em contato com natureza preservada e culturas autóctones, buscam aprofundar seus conhecimentos, gerar benefícios econômicos para as comunidades visitadas e tentam minimizar o impacto da visitação no local, se possível, engajando-se em ações conservacionistas (GUIMARÃES, 2003). A cultura, portanto, é percebida pelos ecoturistas como parte do ambiente visitado. Além disso, a inserção de atrativos culturais em roteiros ecoturísticos é algo que enriquece a experiência, podendo influenciar os mesmos a consumirem esses novos produtos.

Assim, podem ser pensados desdobramentos dos produtos arqueoturísticos aqui propostos em outras tantas atividades, alinhadas às práticas ecoturísticas já estabelecidas, como, por exemplo: (a) durante visitas às comunidades, quase sempre sobrepostas a sítios arqueológicos, podem-se perceber as áreas de ocorrência dos vestígios e visualizar as diferenças entre os mesmos. Neste caso, pode-se pensar, inclusive na elaboração de um Guia de Campo de Cerâmica Arqueológica, nos moldes, por exemplo, dos Guias de Aves tão utilizados por praticantes do turismo de observação de aves (birdwatching), (b) durante trilhas e caminhadas, a interpretação dos costumes alimentares antigos, a partir da apresentação de animais e plantas que faziam parte da dieta dos grupos indígenas, (c) 
durante passeios de canoa, informando sobre os métodos mais antigos de pesca ou (d) proporcionando experiências gastronômicas inspiradas na culinária indígena. Enfim, ideias complementares, focadas no patrimônio arqueológico, em maior ou menor grau, já que na Amazônia é possível estar em sítios arqueológicos em diversas oportunidades. Esses desdobramentos, por sua vez, permitem que as comunidades transmitam aos turistas a sua forma de se relacionar com os sítios arqueológicos locais e a importância que as mesmas atribuem a eles, tendo como base o conhecimento científico sobre os mesmos, mas, principalmente, as suas experiências.

Do mesmo modo, é indicada a criação ou melhoria de Centros de Visitantes, estruturados conforme as recomendações da Interpretação Ambiental/Patrimonial, de forma que estes sejam o primeiro local de contato dos visitantes com o ambiente e com a cultura do município, incluindo a sua riqueza arqueológica.

Em relação aos visitantes vindos de núcleos emissores mais próximos, observa-se que o patrimônio arqueológico de Iranduba competirá, enquanto produto turístico, com outros produtos locais, como as praias e os banhos, que estão ligados muito fortemente ao lazer. Desse modo, os produtos sugeridos devem oferecer atividades diferenciadas que possam interessar a diferentes grupos de pessoas, bem como a pessoas com diferentes interesses num mesmo grupo.

Ponderando sobre todos os possíveis visitantes, é válido enfatizar que a experiência a ser vivenciada nesses locais sempre deverá priorizar a construção de conhecimentos e interpretações próprias e, para isso, tem-se uma gama de opções válidas, desde o estímulo a conversas entre os participantes de um grupo, até, sempre que possível, oportunizar experiências sociais como esportes, concertos, relaxamento, novas práticas e desafios (FI, $s / d)$.

É necessário atentar para o momento atual pelo qual passa o município de Iranduba, já descrito anteriormente nesta tese: o desconhecimento do patrimônio arqueológico local pelo público em geral; as mudanças na dinâmica sócio espacial municipal, devido, fortemente, à construção da ponte sobre o rio Negro; os investimentos que a capital, Manaus, vem recebendo devido à sua escolha como cidade sede para a Copa do Mundo 2014; e as influências que a participação da capital na Copa exercerá sobre o seu entorno 
imediato, como o município de Iranduba, que precisa estar preparado para que possa se beneficiar do fluxo turístico vindouro, bem como dos reflexos causados pela publicidade gerada.

É importante apresentar, neste momento, os dados obtidos em 2010 por Leandro Gustavo Braga, aluno do curso técnico de arqueologia da UEA, com orientação desta autora, na sua Iniciação Científica. A pesquisa desenvolveu-se sob o tema $A$ relação do público com o patrimônio arqueológico no estado do Amazonas: subsídios para o aproveitamento turístico (BRAGA, 2010). Na ocasião, foram entrevistados 112 moradores de Iranduba, em duas amostras, uma na sede municipal (83pessoas) e outra na comunidade do Lago do Limão (29). A pesquisa objetivava mensurar o conhecimento da população sobre arqueologia, identificar como esse conhecimento foi acessado e analisar o interesse da mesma em relação à propagação do Turismo Arqueológico no município. Foram entrevistados moradores de diversas faixas etárias, quase todos com escolaridade média e profissões bastante variadas (comerciantes, estudantes, pescadores, cozinheiras, donas de casa, moto taxista, taxistas etc.). Em relação ao turismo, a maioria dos entrevistados disse acreditar no potencial turístico do município, citando, muitas vezes, as belezas naturais locais como principais atrativos e percebendo a atividade turística como algo bom para a comunidade, principalmente, pela possibilidade de geração de empregos e renda. Em relação à arqueologia, proporcionalmente, mais pessoas ouviram falar sobre arqueologia na comunidade do Lago do Limão do que na sede municipal, apontando a escola como a fonte principal de informações. Na comunidade do Lago do Limão, contudo, a faixa de idade dos entrevistados era mais baixa, muitos deles estudantes, e essa situação pode ser reflexo do trabalho de EP desenvolvido por Carla Carneiro em 2009. Na sede municipal, a escola foi citada apenas por cerca de $1 / 3$ dos entrevistados desta amostra, como também o foram jornais e revistas, filmes e documentários e a televisão. Em geral, os entrevistados das duas amostras (sede e Lago do Limão) demostraram possuir algum conhecimento sobre o assunto, relacionando a ciência arqueológica aos vestígios cerâmicos encontrados no município e esses vestígios, às antigas sociedades indígenas. Grande parte das pessoas afirmou que já tinha visto algum material arqueológico, principalmente cerâmico: $25 \%$ dos entrevistados na primeira amostra (sede) citaram os sítios arqueológicos Hatahara, Laguinho e Paricatuba como locais onde viram esses materiais. Acredita-se que, como esses sítios 
foram escavados por equipes do PAC, em etapas de campo longas, é possível que isso tenha ocorrido nesses períodos, mas isso não foi detalhado. Quando perguntados o que são essas coisas, como foram parar onde estão e para que elas servem, cerca de $1 / 3$ dos consultados nesta amostra preferiu não responder às questões. No entanto, grande parte do total de entrevistados considerou que os vestígios arqueológicos eram muito importantes ou importantes e que precisam ser preservados para as gerações futuras. Quase todos os respondentes nunca estiveram em um museu. Quase todos acreditam que pessoas de fora da comunidade possam ter interesse em visitar Iranduba por conta do patrimônio arqueológico local, mas a pesquisa foi apontada como o principal motivo e o turismo, o segundo. Em pergunta aberta, quase metade dos entrevistados sugeriu a criação de um museu no município e alguns pediram a divulgação das informações científicas obtidas pelas pesquisas arqueológicas que ali ocorreram e, também, a promoção do turismo local.

Esses dados comprovam a dificuldade de acesso a instituições culturais por parte dos comunitários quando estas estão ausentes no seu município, mesmo que existentes em um município vizinho, como é o caso em questão. Os dados indicam a necessidade de investimentos locais em relação à cultura e deixam claro que essas ações são desejadas pela comunidade.

Embora a pesquisa tenha apontado que as pessoas reconhecem a importância e a necessidade de preservação do patrimônio arqueológico, a prática cotidiana ainda aponta em outra direção: visões preconceituosas em relação à descendência indígena, atitudes indesejadas de vandalismo e comércio de peças arqueológicas, destruição fortuita de bens arqueológicos e quase total abandono por parte do poder público. Por isso, em última instância, as propostas aqui apresentadas vislumbram mudanças no relacionamento de todos esses atores com o patrimônio arqueológico local. Acredita-se que o contato profícuo com o patrimônio (que pode ser gerado desde a apresentação dessas propostas para a discussão entre os interessados e o processo participativo necessário para finalizá-las, até as vivências proporcionadas com as suas implantações) possibilite o despertar de orgulho em relação ao mesmo, por parte da comunidade e gestores locais, e o respeito e admiração por parte dos forasteiros. Finalmente, este capítulo deixa como reflexão a frase de Nethery 
(s/d:03): "any conservation effort that fails to culminate in some positive transaction with the public consciousness is not only a doomed but a futile exercise ${ }^{100}$.

${ }^{100}$ qualquer esforço de conservação que não culmine em alguma troca positiva com a consciência do público se constituirá não apenas em um exercício condenado a fracassar, mas também em um exercício inútil [Tradução: Luciana M. Guimarães]. 


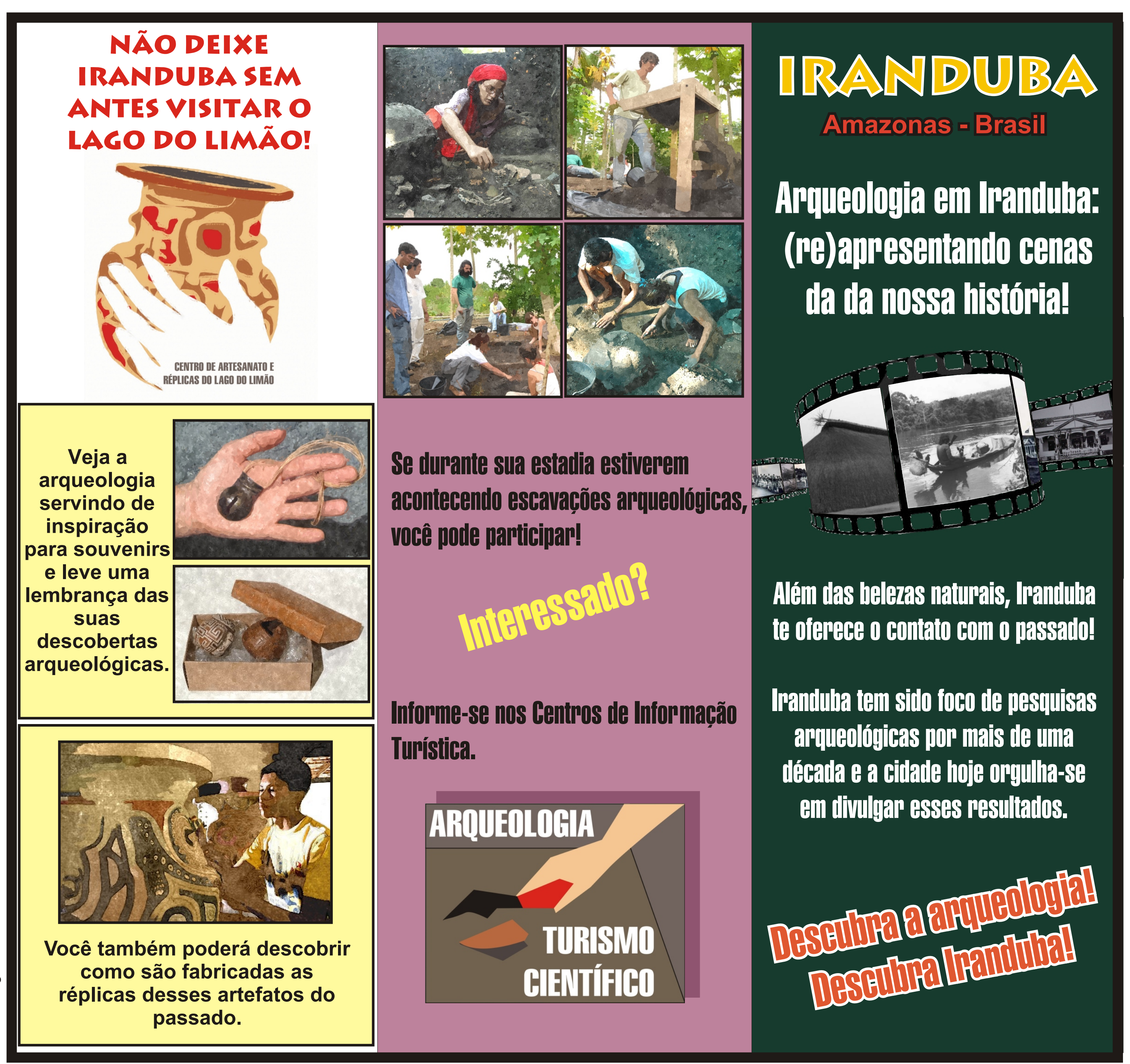


Conheca un tépica Scita

argusealógica amarátrica descubra gue a Amarônia cãa é tãa wirgen quavio wocê pensava!

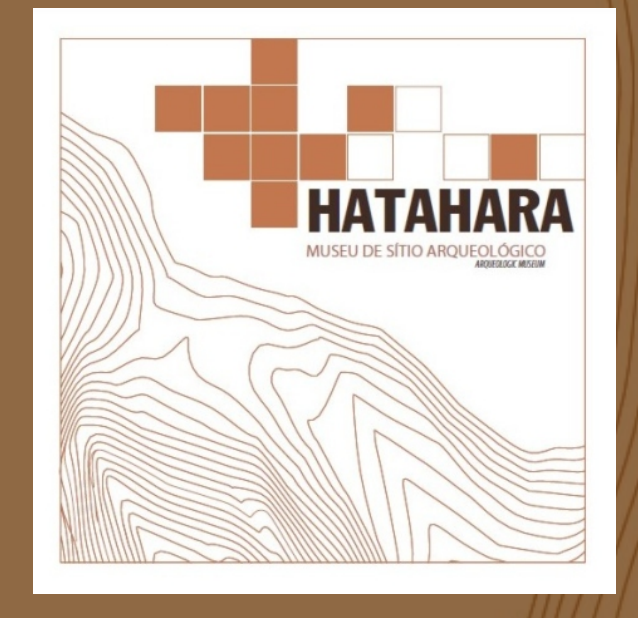

UMA FLORESTA TOCADA.

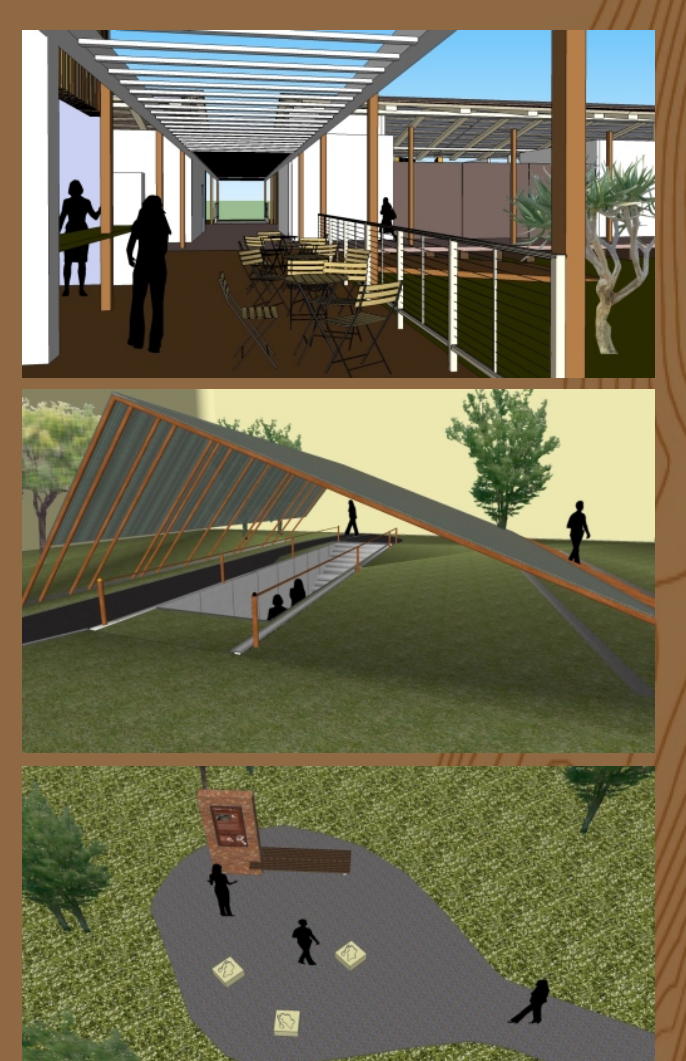

回 Museu

- Trilha de quase $1 \mathrm{~km}$

— Laboratório de arqueologia

Horário de funcionamento do Museu: Terça a Domingo ( $X X$ às $X X$ hs)

Informaçōes: (Xx@xxxx);
VILA DE PARICATUBA

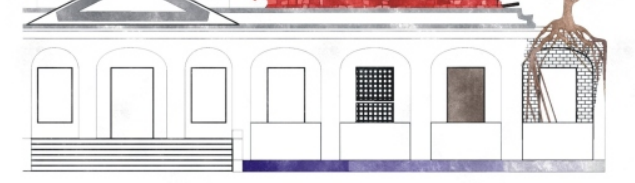

(Des)continuidadies: o mesmo espaç, diferentes histórias.

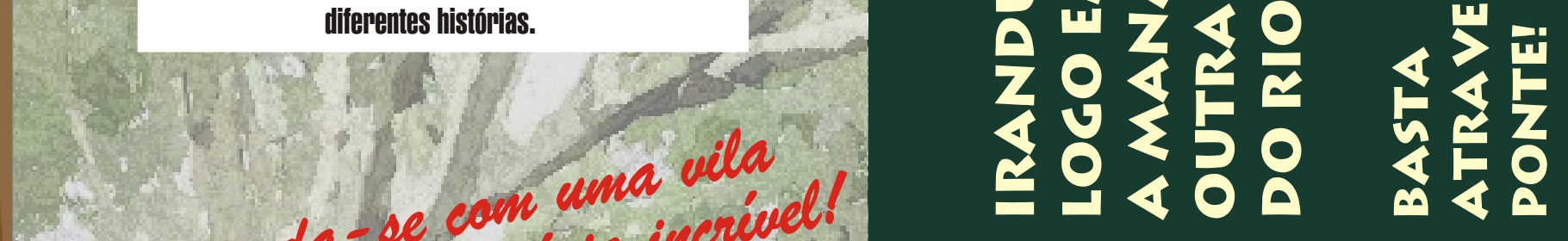

Sumpreenda - de com unisiória incrivel! Acrarzanica do visita à vila de Paricatuba Sítio Arqueológico Centro Cultural

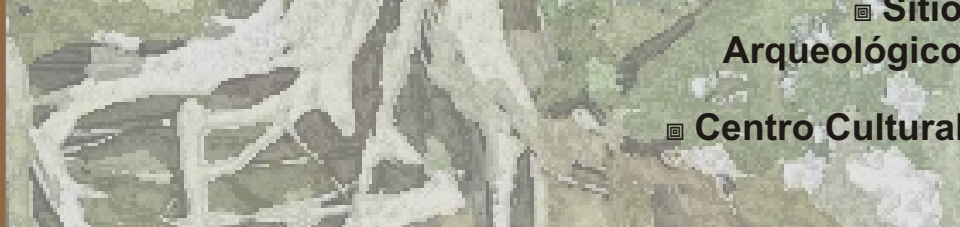

- 1 1 A conheça o prédio áurea da borracha,

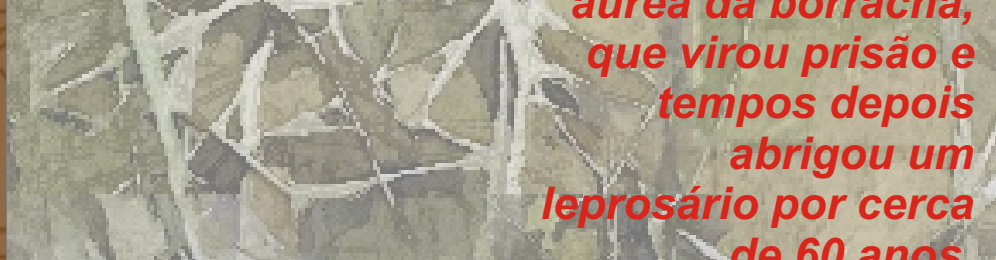

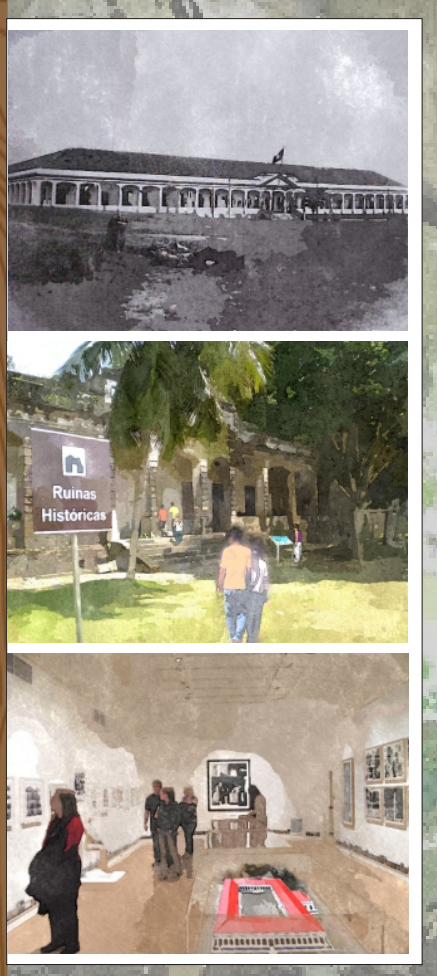

$-1, i$

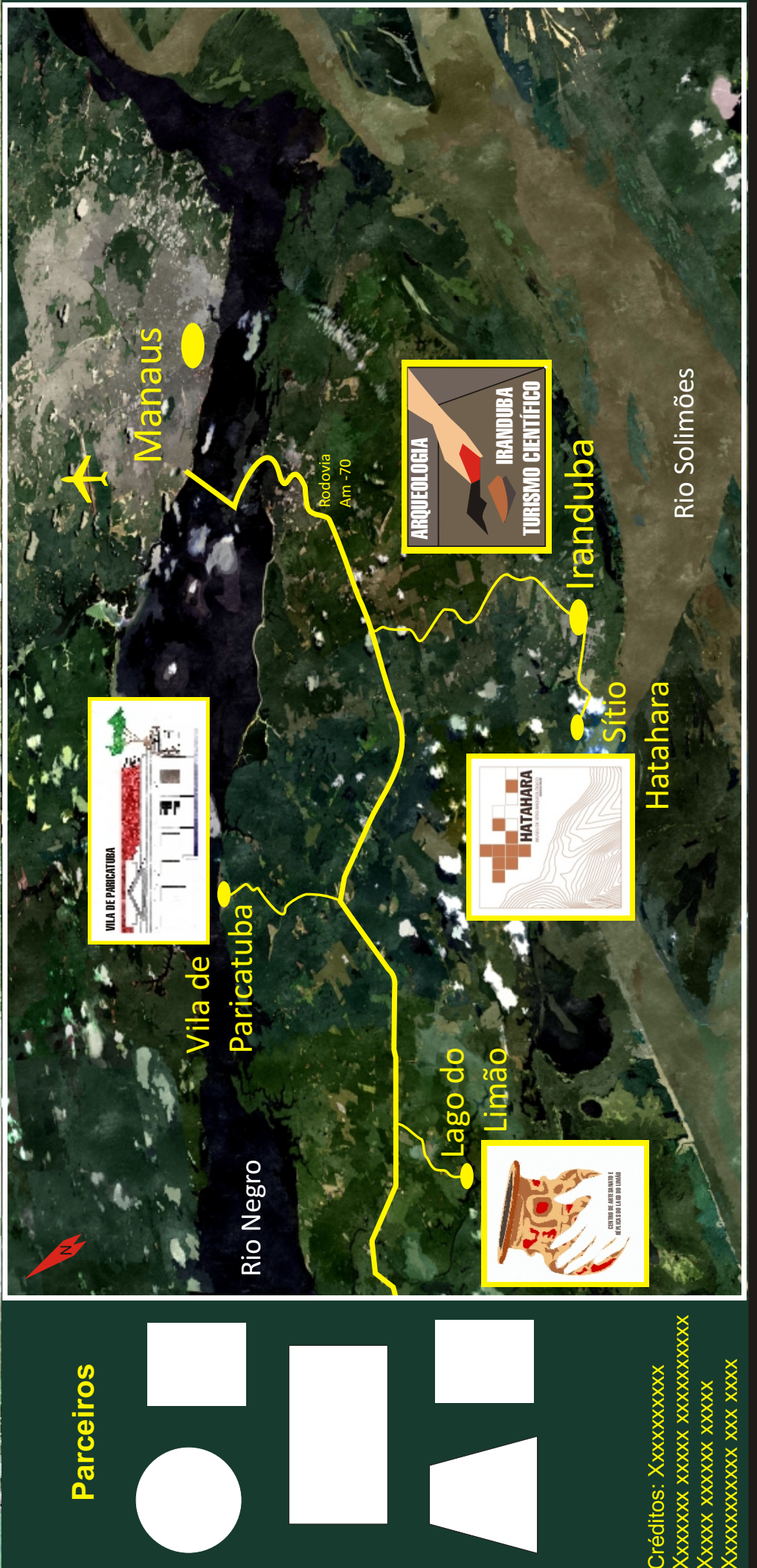

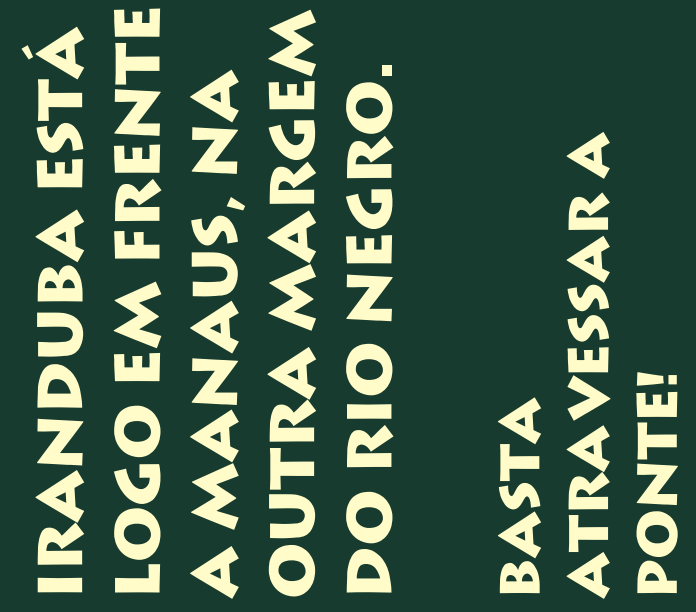

Ilustração IV.26 (frente e verso). Layout de um folder turístico promocial do município de Iranduba, caso sejam implantadas as propostas contidas nessa tese. 


\section{CONSIDERAÇÕES FINAIS}

Esta tese partiu de duas hipóteses que levaram em consideração as discussões sobre o fato de a pouca monumentalidade dos sítios arqueológicos brasileiros ser um empecilho ao desenvolvimento da atividade arqueoturística. O seu encaminhamento, porém, demonstrou que a falta de monumentalidade talvez não seja, de fato, o que mais dificulta a inserção do patrimônio arqueológico no sistema de turismo local, regional ou nacional, e isso é uma lição genérica.

De fato, como se demonstrou ao longo deste trabalho, o Turismo Arqueológico, principalmente quando se trata de sítios pouco monumentais, precisa de muito esforço para acontecer. Esse esforço, por sua vez, precisa ser interdisciplinar e participativo já que o foco não deve ser direcionado apenas aos sítios arqueológicos. Pensar o Turismo Arqueológico é pensar, também, nas pessoas: nos moradores do entorno dos sítios, como uma forma de geração de emprego e renda, propiciada pela devolução de todo o conhecimento gerado com as pesquisas locais; nos visitantes de todas as partes do país ou do mundo que terão a possibilidade de confrontar realidades antigas distintas das dos seus locais de origem e, com isso, se enriquecerem culturalmente.

Contudo, alguns fatores complicadores para a inserção do patrimônio arqueológico no sistema turístico puderam ser percebidos: (i) a falta de planejamento turístico generalizado, conforme relatado no capítulo III, (ii) a descrença dos arqueólogos brasileiros em geral em relação aos benefícios do turismo, e a pouca compreensão dos mesmos sobre o assunto, (iii) a pouca apropriação do conhecimento advindo das práticas arqueológicas, tanto por parte das comunidades locais, quanto do poder público e (iv) a desconfiança desses diversos atores sobre a possibilidade de aproveitamento turístico de sítios arqueológicos pouco monumentais, ou pouco aparentes na paisagem, como os sítios de Terra Preta na Amazônia, o que dificulta parcerias.

$\mathrm{Na}$ experiência desta tese, o conhecimento arqueológico gerado pelo PAC foi o que possibilitou a concepção de atrativos arqueoturísticos na realidade confrontada, aliado ao 
conhecimento da teoria turística e das técnicas de Interpretação Patrimonial. Acredita-se que é o conhecimento arqueológico, gerado com as pesquisas arqueológicas, quer acadêmicas, quer contratuais, que pode dar poder as comunidades locais para que elas mesmas sejam o motor de mudanças nas suas realidades socioeconômicas, cobrando, do poder público, ações integradas e participativas de gestão do patrimônio arqueológico local que, principalmente, se revertam em conservação do mesmo.

Para isso, considera-se fundamental que os arqueólogos reconheçam as necessidades práticas cotidianas das comunidades com as quais trabalham, disponibilizando-lhes as informações que possuem, de forma clara, e apresentando as diversas possibilidades existentes, inclusive o aproveitamento turístico dos sítios arqueológicos, para que as mesmas decidam o seu futuro. Antes, porém, precisam acolher o turismo como uma atividade importante para a promoção e a proteção do patrimônio arqueológico, perfeitamente cabível no processo de gestão do patrimônio arqueológico, e compreender a sua abrangência e importância social, cultural e econômica. Enquanto isso não acontece, diversos sítios arqueológicos continuam vulneráveis e vão-se trocando sítios arqueológicos por medidas mitigatórias, que pouco beneficiam o patrimônio e as comunidades, e se perpetua um grave desperdício de oportunidades.

Turismo Arqueológico não significa, simplesmente, levar pessoas a um sítio arqueológico e também não depende apenas de sinalização informativa. O planejamento de produtos arqueoturísticos é uma atividade complexa, que deve ser pensada em consonância com os princípios para as melhores práticas para a atividade arqueoturística aqui reunidos.

Esta tese propõe o aproveitamento turístico de apenas dois sítios arqueológicos, em contraponto às dezenas de sítios destruídos pelas tantas outras ações desenvolvimentistas em andamento na região. Não é preciso transformar todos os sítios arqueológicos de Iranduba em atrativos turísticos. Fazer isso, ao contrário, seria criar atrativos que competiriam entre si e isso, definitivamente, não interessa. Selecionar alguns sítios arqueológicos, realizar um trabalho consistente, difundir a temática através de equipamentos distintos (no caso, um museu de sítio, trilhas, ruínas interpretadas e desenvolvimento de souvenirs com temática volta à arqueologia) seria suficiente para aumentar a proteção ao patrimônio arqueológico local e para a difusão do conhecimento 
arqueológico, tornando-o de fácil acesso a todos. Em outras palavras, isso se resume em dar sentido às práticas arqueológicas, um sentido diferente do atual "retirar e guardar em museus". Deixa-se essa reflexão!

O PAC não existe mais, o CABA não foi construído, o sítio Hatahara está fechado ao público com todas as informações que carrega, as ruínas de Paricatuba continuam desprezadas e caindo diariamente e os moradores sendo expulsos da comunidade. Isso está longe de ser a realidade pretendida quando se consideram os mais de 15 (quinze) anos de pesquisas arqueológicas locais, que envolveram nesse período mais de 50 (cinquenta) arqueólogos brasileiros e estrangeiros que ali obtiveram treinamento e evoluíram profissionalmente. A angústia maior, no entanto, é em relação às pessoas que assistiram ao desenvolvimento das pesquisas arqueológicas durante esse percurso de tempo e depositaram esperanças em ter suas realidades modificadas através das práticas arqueológicas.

Espera-se, sinceramente, que a síntese teórica desta tese auxilie no entendimento dessa temática e esclareça, pelo menos, um pouco das dúvidas que rondam as iniciativas de Turismo Arqueológico no Brasil. Como já foi dito nesta tese, considera-se urgente que um novo olhar - por parte do turismo e da arqueologia - seja lançado ao imenso patrimônio arqueológico nacional, o que significa organizar e planejar o seu uso público e estimular a interdisciplinaridade para garantir a qualidade e diversidade do acesso a esse patrimônio.

A máxima só se preserva aquilo que se ama, e só se ama aquilo que se conhece, tão difundida para as questões ambientais, serve também para o patrimônio arqueológico. Educação é fundamental, mas pode ser obtida de diversas formas. Lazer e turismo são fontes inesgotáveis de conhecimento, um conhecimento que se obtém na vivência, na experiência, no contato desobrigado. O planejamento e a prática desta atividade envolvem comunidades, gestores e visitantes e são chances concretas de mudança de realidades.

A tentativa foi feita e a semente está plantada... 


\section{REFERÊNCIAS BIBLIOGRÁFICAS}

AHC (Australian Heritage Comission) and CRC for Sustainable Tourism. Successful Tourism at Heritage Places - a Guide for Tourism Operators, Heritage Managers and Communities. 2001.

AIA, Archaeology Magazine and ATTA. A Guide to Best Practices for Archaeological Tourism. USA. s/d. Disponível em: http://www.archaeological.org/webinfo.php?page=10482. Último acesso: set./2011.

ALFONSO, Louise Prado. O Patrimônio Arqueológico e sua Vinculação a Circuitos Turísticos não Convencionais no Brasil. Congresso Ecos del 53 ICA- Encontro Internacional de Americanistas. México, jul./2009. Disponível em: http://www.historiahistoria.com.br/materia.cfm?tb=artigos\&id=104. Último acesso: dez./2011.

ALMEIDA, Éricka Ma . C. de Amorim. Planeamento Turístico - Proposta Metodológica para Municípios Brasileiros de Pequena e Média Dimensão. (Dissertação) Portugal: Universidade de Aveiro, 2006.

ALVES, Juliana Araújo e OLIVEIRA, José Aldemir de. A política de isolamento para a hanseníase e a saúde pública: a geografia do isolamento em Manaus AM, Brasil. Revista Geográfica de América Central, Número Especial EGAL. 2011.

ANDRADE, Marcela Nogueira de. Turismo e Arqueologia na Amazônia: Planejamento e Visitação de Sítios Arqueológicos na Região da Serra dos Martírios/Andorinhas. (Trabalho de Conclusão de Curso). Belém, PA: Universidade Federal do Pará, Departamento de Turismo, 2007.

ARA (Articulação Regional Amazônica). A Amazônia e os Objetivos do Milênio. Eds. D. Celentano; M. Vedoveto. ARA Regional: Quito, Equador. 2011.

ARGÔLO, Djaneide Silva; BOMFIM, Natanael Reis. Relação entre atividade turística, apropriação do território e patrimônio: uma contribuição para o planejamento sustentável do turismo na Bahia. Revista Brasileira de Pesquisa em Turismo. Vol. 2, N .3 , nov./2008.

ASSIS, Wilson R. O Patrimônio Cultural e a Tutela Jurídica das Identidades. In: CUREAU, Sandra; KISHI, Sandra A. S.; SOARES, Inês Virgínia P. e LAGE, Claudia Marcia F. (Coord.) Olha Multidisciplinar sobre a efetividade da proteção do patrimônio cultural. Belo Horizonte: Fórum, 2011.

AYRES, José Márcio. As matas de várzea do Mamirauá: médio Solimões. Brasília, DF: CNPQ: Sociedade Civil Mamirauá, 1993.

BANCO DA AMAZÔNIA. Plano de Incentivo ao Turismo na Amazônia. Belém, PA. 2009.

BARRETO, Margarita e REJOWSKI, Mirian. Considerações epistemológicas sobre segmentação: das tipologias turísticas à segmentação de mercado. In: PANOSSO NETTO, Alexandre e ANSARAH, Marilia G. dos Reis (Eds.). Segmentação do mercado turístico: estudos, produtos e perspectivas. Barueri, SP: Manole, 2009. 
BENI, Mário C. Análise Estrutural do Turismo. São Paulo: SENAC, 1998.

BIESEK, Ana Solange. Turismo e Interpretação do Patrimônio Cultural. São Miguel das Missões. Rio Grande do Sul. Brasil. (Dissertação) Rio Grande do Sul: Universidade de Caxias do Sul, 2004.

BRAGA, Leandro Gustavo Rego. A relação do público com o patrimônio arqueológico no estado do Amazonas: subsídios para o aproveitamento turístico. (Iniciação Científica). Iranduba, AM: Universidade do Estado do Amazonas, Curso Superior de Tecnologia em Arqueologia, 2010.

BRASIL, Secretaria Nacional de Políticas de Turismo, Ministério do Turismo. Anuário Estatístico de Turismo 2011. Vol. 38. (Ano Base 2010).

BRASIL, Secretaria Nacional de Políticas de Turismo, Ministério do Turismo. Anuário Estatístico de Turismo 2012. Vol. 39. (Ano Base 2011).

BRASIL. Ministério do Turismo, FGV e SEBRAE. Estudo de competitividade dos 65 destinos indutores do desenvolvimento turístico regional - Relatório Brasil. Brasília: Ministério do Turismo, s/d.

BRASIL. Plano Nacional de turismo 2007/2010. Brasília: Ministério do Turismo, 2007.

BRASIL. Turismo cultural: orientações básicas. Turismo Cultural. 2ed. Brasília: Ministério do Turismo, 2008.

BRUNO, Maria Cristina O. Arqueologia e antropofagia: a musealização de sítios arqueológicos. In: Revista do Patrimônio Histórico e Artístico Nacional. №. 31. Brasília: IPHAN, 2005.

BUCHAIM, Joaquim Jorge Silveira. Arqueologia, turismo, meio ambiente e sustentabilidade. Anais. XIII Congresso da SAB: arqueologia, patrimônio e turismo - Campo grade, MS: Ed. Oeste, 2005.

CALDARELLI, Solange Bezerra. Fatores causadores de impacto sobre bens arqueológicos na Amazônia. Apresentado no I Seminário Internacional de Gestão do Patrimônio Arqueológico Pan-Amazônico. Scientia Consultoria Científica. Disponível em: http://www.scientiaconsultoria.com.br/site2009/pdf/artigos/Arqueologia_amazonica_fat ores.pdf. Último acesso: fev./2012.

CAPOBIANCO, João Paulo R. et al (orgs.). Biodiversidade na Amazônia brasileira: avaliação e ações prioritárias para a conservação, uso sustentável e repartição de benefícios. São Paulo: Estação Liberdade; Instituto Socioambiental, 2001.

CAPRA, Fritjof. As Conexões Ocultas. Ciência para uma vida sustentável. São Paulo: Ed. Cultrix, 2002.

CARBONE, Fabio e COSTA, Carlos. Archaeology, Tourism and Sustainable Development. A new model for archaeological heritage management. XV Congresso UISPP - International Union for Prehistoric and Protohistoric Sciences. (Lisboa, Portugal, setembro de 2006. Disponível em: http://www.pluridoc.com/Site/FrontOffice/default.aspx?module=Files/FileDescription\&l $\underline{D=2961 \& \text { state }=F D}$. Último acesso: abr./2010.

CARNEIRO, Carla Gibertoni. Ações educacionais no contexto da arqueologia preventiva: uma proposta para a Amazônia. (Tese) São Paulo: MAE/ USP, 2009. 
CARNEIRO, Edivasco; OLIVEIRA, Sofia Araújo de; CARVALHO, Karoliny Diniz. Turismo Cultural e Sustentabilidade: Uma relação possível? Revista Eletrônica de Turismo Cultural, Vol. 4, $N^{0} .1,2010$.

CARTER, James (ed.). A sense of place - an interpretive planning Handbook. 2ed. Rev. (formato eletrônico) England: Scottish Interpretation Network. Disponível em: www.scotinterpnet.org.uk. 2001.

CASTRO, Ana Lúcia Siaines de. Museu e Turismo: uma relação delicada. (Comunicação oral) VIII ENANCIB. Salvador, BA. 2007. Disponível em: http://www.enancib.ppgci.ufba.br/artigos/DMP--257.pdf. Último acesso: out./2011.

CASTRO, Márcio Walter de Moura. A cronologia dos sítios Lago do Iranduba e Laguinho à luz das hipóteses da ocupação humana para a Amazônia central. (Dissertação) São Paulo: MAE/ USP, 2009.

CHRISTOU, Evangelos. Heritage and cultural tourism: A marketing-focused approach. In: SIGALA, M. \& LESLIE, D. (eds.) International Cultural Tourism: Management, Implications and Cases. London: Elsevier Butterworth-Heinemann, 2005.

CHUVA, Marcia. Entre Vestígios do Passado e Interpretações da História - Introdução aos Estudos sobre Patrimônio Cultural no Brasil. In: CUREAU, Sandra; KISHI, Sandra A. S.; SOARES, Inês Virgínia P. e LAGE, Claudia Marcia F. (Coord.) Olhar Multidisciplinar sobre a efetividade da proteção do patrimônio cultural. Belo Horizonte: Fórum, 2011.

COMISSÃO Mundial sobre Meio Ambiente e Desenvolvimento. Nosso Futuro Comum. Rio de Janeiro: Fundação Getúlio Vargas, 1991.

CONACULTA. El ABC del Patrimonio Cultural y Turismo. México. Disponível em: www.conaculta.gob.mx/patrimoniocultural, s/d.

CORDEIRO, Itamar Dias e; LEITE, Nathália Körössy e PARTIDÁRIO, Maria do Rosário. Instrumentos de avaliação de sustentabilidade de destinos turísticos: uma revisão de literatura. Caderno Virtual de Turismo, Nº. 10, Vol.2, 2010.

CORTEZÃO, Raphael. Iranduba. Portal Amazônia/ Folha do Turismo. Disponível em: http://portalamazonia.globo.com/artigo amazonia az.php?idAz=713. Último acesso: fev./2009.

COSTA, Fernando Walter da S. Arqueologia das campinaranas do baixo rio Negro: em busca dos pré-ceramistas nos areais da Amazônia Central. (Tese) São Paulo: MAE/ USP, 2009.

COSTA, Márcio Antônio Leal. Segmentação do mercado turístico: o caso do destino Brasil. (Dissertação) Ilhéus, BA: UESC, 2006.

COSTA, Sabrina Campos. O Planejamento do uso turístico de sítios arqueológicos: o patrimônio arqueológico de Santana do Tartarugueiro, Ponta de Pedras Marajó (PA). (Monografia) Belém: UFPA, 2008.

CRUZ, Gustavo; BERBERI, André Portes Caldini e GUZELA, Morgana Toaldo. Ciência e Pesquisa: reflexões sobre a inserção do turismo e do ensino superior frente ao panorama científico. Passos. Vol. 6. Nº. 1., 2008.

CUREAU, Sandra; KISHI, Sandra A. S.; SOARES, Inês Virgínia P. e LAGE, Claudia Marcia F. (Coord.) Olhar Multidisciplinar sobre a efetividade da proteção do patrimônio cultural. Belo Horizonte: Fórum, 2011. 
CURY, Marília X. Para saber o que o público pensa sobre arqueologia... Revista Arqueologia Pública, Nº. 1. São Paulo, 2006.

DE BLASIS, Paulo. Da era das glaciações às origens da agricultura. Uma revisão das mais antigas culturas do território brasileiro. In: Brasil 50 mil anos - Uma viagem ao passado pré-colonial. São Paulo, SP: Edusp, MAE/USP, 2001.

DENEVAN, William M. (Ed.). The native population of the Americas in 1492. 2ed. Madison: University of Wisconsin, 1992.

DENEVAN, William M. The aboriginal population of Amazonia. In: DENEVAN, William M. (Ed.). The native population of the Americas in 1492. Madison: University of Wisconsin, 1976.

DENKER, A. F. M. Métodos e Técnicas de Pesquisa em Turismo. São Paulo: Futura, 2002.

DIAS, Adriana Schmidt. Caminhos Cruzados? Refletindo sobre os Parâmetros de Qualidade da Prática Arqueológica no Brasil. Arqueologia em Debate. Jornal da Sociedade de Arqueologia Brasileira, N. 2. out./ 2010.

DIAS, Reinaldo e AGUIAR, Marina R. Fundamentos do Turismo: conceitos, normas e definições. Campinas, SP: Editora Alínea, 2002.

DONATTI, P. B. A ocupação pré-colonial da área do Lago Grande, Iranduba, AM. (Dissertação de mestardo) São Paulo: MAE/USP, 2003.

DUARTE, Germana de Vasconcelos; BARATA NETO, Humberto Dias Ferreira; BENZECRY, Ingrid Myrian Lira; KUCK, Tahisa Neitzel e ARRUDA, Thaís Renata Batista. O Patrimônio de Paricatuba: Memória e Espaço. Centro Universitário Luterano de Manaus. Arquitetura e Urbanismo. 2002.

ERICKSON, C. L. Amazonia: The Historical Ecology of a Domesticated Landscape. In: SILVERMAN, Helaine and ISBELL, Willian (ed.). Handbook of South American Archaeology. New York: Springer, 2008.

FAULKNER, Bill (H. W.). Desenvolvimento de abordagens estratégicas ao marketing de destino turístico: a experiência da Austrália. In: THEOBALD, Willian F. (org.). Turismo Global. São Paulo: SENAC São Paulo, 2001.

FAUSTO, Carlos. Os Índios antes do Brasil. Rio de Janeiro: Jorge Zahar Editor, 2000.

FERNÁNDEZ, Ana Lozano. Sí, es útil estudiar interpretación en um Curso de Gestión del Patrimonio Cultural. Boletín de Interpretación. Boletín de Interpretacíon. Asociación para la Interpretación del Patrimonio - AIP. España. Nº. 1, Jun./ 1999.

FI (Fáilte Ireland). Sharing our Stories. Using interpretation to improve the visitors' experience at heritage sites. s/d. Disponível em: www.failteireland.ie.

FLORES, Elio Chaves. As Fundações Historiográficas da Turismologia. Sæculum - REVISTA DE HISTÓRIA [12]; João Pessoa, jan./ jun. 2005.

FRANCO, Maria Ignez Mantovani. O processo de elaboração do programa museológico. In: Seminário Arquitetura em Museus - Perspectivas Contemporâneas. Centro Cultural Banco do Brasil de São Paulo, 2005. 
FREIRE, Doia e PEREIRA, Ligia Leite. História Oral, Memória e Turismo Cultural. In: MURTA, Stela Maris e ALBANO, Celina (org.) Interpretar o Patrimônio, um exercício do olhar. 2ª. ed. Belo Horizonte: Ed. UFMG; Território Brasilis, 2005.

FREYRE, Gilberto. Casa-grande \& Senzala. Rio de Janeiro: Maia \& Schmidt Ltda., 1933.

GAMBLE, Clive. Archaeology: The Basics. London: Routledge, 2004.

GÂNDARA, José Manoel Gonçalves. La sostenibilidad de los destinos turísticos urbanos. Disponível em: www.obstur.ufpr.br/artigos-planurb.html. Último acesso: out./2011.

GASPAR, Ma Dulce. Os ocupantes pré-históricos do litoral brasileiro. In: TENÓRIO, Ma Cristina. Pré-história da Terra Brasilis. Rio de Janeiro: Editora da UFRJ, 2000.

GONÇALVES, Eduardo C. Turismo cultural como factor de desenvolvimento das regiões. In: Dinâmicas de rede no Turismo Cultural e Religioso - Livro de Resumos. Maia: Edições ISMAI e CEDTUR. 2009

GONZÁLEZ, Marco Antonio; CORDERO, Martha Rosa e GONZÁLEZ, Benjamín Silva. Web Virtual Ball Game "Pok-Ta-Pok". Journal of Theoretical and Applied Information Technology. Vol. 34, $\quad \mathrm{N}^{\circ} 1 . \quad$ Dec./2011. Disponível em: http://www.jatit.org/volumes/Vol34No1/2Vol34No1.pdf. Último acesso: abr./2012.

GUERRA, Francisco J. Elementos para el debate. Boletín de Interpretacíon. Asociación para la Interpretación del Patrimonio - AIP. España. N. 1, Jun./ 1999.

GUIDÓN, Niède. Parque Nacional Serra da Capivara. Modelo de Preservação do Patrimônio Arqueológico Ameaçado. In: LIMA, Tania Andrade (Org.). Patrimônio Arqueológico: o desafio da preservação. Revista do Patrimônio Histórico e Artístico Nacional. $N^{\circ} .33$. Brasília/DF: IPHAN, 2007.

GUIMARÃES, Adriana M. Avaliação do interesse dos brasileiros pelo Turismo Arqueológico (TA). Revista do Museu de Arqueologia e Etnologia da Universidade de São Paulo. Anais da II Semana de Arqueologia. Suplemento 11, 2011.

GUIMARÃES, Adriana M. Distorções entre o conceito e a prática do ecoturismo: o caso de Itacaré, Bahia. (Dissertação) Bahia: Universidade Estadual de Santa Cruz, 2003.

GUIMARÃES, Roberto P.; FEICHAS, Susana A. Q. Desafios na construção de indicadores de sustentabilidade. Ambiente \& Sociedade. Vol.12, N. 2, Campinas, jul./dez. 2009 (Versão ISSN 1414-753X).

HERITAGE LOTTERY FUND. Thinking about... Interpretation. 2009. Disponível em: www.hlf.org.uk. Último acesso: mar./2012.

HORNBORG, A. Ethnogenesis, Regional Integration, and Ecology in Prehistoric Amazonia: Toward a System Perspective. Current Anthropology 46: 589-620, 2005.

HORTA, M. L. P. Guia básico de educação patrimonial. Brasília: IPHAN, Rio de Janeiro: Museu Imperial, 1999.

HOUAISS, Antônio; VILLAR, Mauro de Salles e FRANCO, Francisco Manoel de Mello. Dicionário Houaiss da Língua Portuguesa. Objetiva, 2001.

IBGE.

Amazonas.

Disponível

em:

http://www.ibge.gov.br/home/estatistica/populacao/censo2010/resultados_dou/AM201 0.pdf. Último acesso: jul./2011. 
IBGE. Censo 2010. Resultados divulgados no Diário Oficial da União em 04.11.2010. Disponível em: http://www.ibge.gov.br/home/estatistica/populacao/censo2010/resultados dou/AM201 0.pdf. Último acesso: fev./2012.

IBGE. Cidades. Disponível em: http://www.ibge.gov.br/cidadesat/default.php. Último acesso: jun./2007.

ICOMOS Australia. Burra Charter (revised) for the conservation of Places of cultural significance.1999a.

ICOMOS WORLD REPORT 2008-2010 ON MONUMENTS AND SITES IN DANGER. Heritage at Risk. MACHAT, Christoph; PETZET, Michael and ZIESEMER, John (Ed.). 2010.

ICOMOS. Charter for the Protection and Management of the Archaeological Heritage. 1990.

ICOMOS. International Cultural Tourism Charter. Principles and Guidelines for Managing Tourism at Places of Cultural and Heritage Significance. ICOMOS International Cultural Tourism Committee. 1999b.

IRVING, Marta de Azevedo; BURSZTYN, Ivan; SANCHO, Altair P. e Melo Gustavo de M. Revisitando significados em sustentabilidade no planejamento turístico. Caderno Virtual de Turismo Vol. 5, №. 4. 2005.

KÖHLER, A. F.; DURAND, J. C. G. Turismo cultural: conceituação, fontes de crescimento e tendências. Revista Turismo -Visão e Ação (Itajaí), Vol. 9, p. 185-198, 2007.

KRAMER, Paulo. Sobrevivência e sustentabilidade: um desafio amazônico. Publicado em: 11/12/2008. Disponível em: http://congressoemfoco.ig.com.br. Último acesso: out./2010.

LACERDA, Danielle Christine Othon. A importância do turismo cultural para a sustentabilidade do patrimônio arqueológico. Anais. XIII Congresso da SAB: arqueologia, patrimônio e turismo - Campo Grade, MS: Ed. Oeste, 2005.

LAMA - Levantamento Arqueológico no Município de Manaus/ AM. Relatório Final. 2007.

Lancaster County Heritage (LCH) e York County Heritage (YCH). Telling Our Stories. An Interpretation Manual for Heritage Partners. Pennsylvania, 2007. Disponível em: http://www.nps.gov/heritageareas/REP/REP/interpretation manual.pdf. Último acesso: abril/ 2012.

LATHRAP, Donald. Our Father the Cayman, Our Mother the Gourd: Spiden Revisited or a Unitary Model for the Emergence of Agriculture in the New World. In: REED, C. (ed). Origns of Agriculture. The Hague: Mouton. 1977. p: 713-751.

LATHRAP, Donald. The Upper Amazon. New York: Praeger Publishers, 1970.

LEA DAVIDSON, Thomas. O que são viagens e turismo: constituem de fato um setor? In: THEOBALD, Willian F. (org.). Turismo Global. São Paulo: SENAC São Paulo, 2001.

Lei №. 3.924 de 26 de julho de 1961 (Dispõe sobre os monumentos arqueológicos e préhistóricos).

LIM, Jong H. Archeological Site Management Planning: Focused on a Study of Management Guidelines for Hwangryong Temple Historic Site. (Thesis) Pennsylvania: University of Pennsylvania, 2005. 
LIMA, Helena Pinto. História das caretas: a tradição Borda Incisa na Amazônia Central. (Tese) São Paulo: MAE/ USP, 2008.

LIMA, Tania Andrade. Um passado para o presente: preservação arqueológica em questão. In: LIMA, Tania Andrade (Org.). Patrimônio Arqueológico: o desafio da preservação. Revista do Patrimônio Histórico e Artístico Nacional. Nº. 33. Brasília/DF: IPHAN, 2007.

LIMA, L. P. e FRANCISCO, G. da S. O que é isso? Para que serve? Quem são vocês? O que fazem? Uma experiência de arqueologia pública em Paraná - TO. Revista Arqueologia Pública, Nº. 1. São Paulo, 2006.

LMG (Landesmarketing Sachsen-Anhalt GmbH). RFO-TouriSME Programme. Best Practice Guide. A 'Six Step Process' for the Development of Sustainable Tourism based on Cultural Heritage. Report 2003-2006.

LOBATO NETO, Oduval. Turismo: fator de desenvolvimento da Amazônia. Turismo Sustentável. (Monografia). Rio de Janeiro: Escola Superior de Guerra (ESG), 2001.

LUI, Gabriel Henrique e MOLINA Silvia Maria Guerra. Ocupação humana e transformação das paisagens na Amazônia brasileira. Amazônica - Revista de Antropologia, Vol. 1, No. 1, 2009.

LUÍNDIA, Luiza Elayne Azevedo. Análise do tratamento dado aos conteúdos dos sites dos hotéis de selva: Ariaú Towers e Pousada Ecológica Aldeia dos Lagos (Amazonas). In: Intercom - Sociedade Brasileira de Estudos Interdisciplinares da Comunicação. XXX Congresso Brasileiro de Ciências da Comunicação - Santos - 29 de agosto a 2 de setembro de 2007.

MACHADO, J. S. Montículos Artificiais na Amazônia Central: um estudo de caso do sítio Hatahara (Dissertação de mestrado) São Paulo: MAE/ USP, 2005.

MANZATO, Fabiana. Turismo arqueológico - Diagnóstico em Sítios Pré-Históricos ou Históricos no Estado de São Paulo. (Dissertação) Rio Grande do Sul: Universidade Caixias do Sul, 2005.

MARINO, Eduardo e KISIL, Rosana. Local Productive Arrangements: The Silves Case. ISTR Eighth International Conference -"The Third Sector and Sustainable Social Change: New Frontiers for Research". Barcelona, 2008.

MARTÍN, Marcelo. La Interpretación como un vínculo patrimonio-sociedad. Reflexiones de un profano en rojo y azul. Boletín de Interpretación. Asociación para la Interpretación del Patrimonio. España. $\mathrm{N}^{\circ}$. 3, Jun./ 2000.

MARTín, Marcelo. Patrimonio y Sociedad El conocimiento mutuo como estrategia de una gestión coordinada entre el medio ambiente y la cultura. Boletín de Interpretación. Asociación para la Interpretación del Patrimonio. España. № .17, Oct./ 2007.

MARTÍN, Marcelo. Reflexiones críticas sobre Patrimonio, Turismo y Desarrollo Sostenible II. Boletín de Interpretación. Asociación para la Interpretación del Patrimonio. España. N.6, Ene./ 2002.

MARTín, Marcelo. Sobre el necesario vínculo entre el patrimonio y la sociedad. Reflexiones críticas sobre Patrimonio, Turismo y Desarrollo Sostenible. Património. Estudos. Instituto Português do Património Arquitetônico. N.1. Lisboa: Ministério da Cultura, 2001. 
MEGGERS, Beth. Environmental Limitation on the Development of Culture. American Anthropologist, 56. 1954. p: 801-823.

MEGGERS, Beth. Judging the Future by the Past: The Impact of Environmental Instability on Prehistoric Amazonian Populations. In: Indigenous People \& the Future of Amazônia. The University of Arizona Press. 1995.

MIRANDA, Evaristo Eduardo de. Quando o Amazonas corria para o Pacífico: uma história desconhecida da Amazônia. Petropolis, RJ: Vozes, 2007.

MIRANDA, Marcos Paulo de S. Tutela penal do patrimônio arqueológico brasileiro. Disponível em: http://jus2.uol.com.br/doutrina/texto.asp?id=2738. Último acesso: dez./2009.

MONCAYO, Vanúbia Araújo L. e RIBEIRO, Joana D'Arc. O turismo praticado pela pousada ecológica Aldeia dos Lagos junto às comunidades de São João, Santa Luzia do Sanambi e São Sebastião do Itapani no município de Silves, Amazonas. Revista Passos, Vol.3, N.1, p.87-95. 2005.

MONTICELLI, Gislene. Arqueologia em Obras de Engenharia no Brasil: Uma Crítica aos Contextos. (Doutorado) Porto Alegre, RS: PUCRS, 2005.

MORAES, Claide. Arqueologia na Amazônia Central Vista de Uma Perspectiva da Região do Lago do Limão. (Dissertação) São Paulo: MAE/USP, 2006.

MORALES, Jorge e PASTOR, Gabriela. ¿Sólo para el público general? Boletín de Interpretación. Asociación para la Interpretación del Patrimônio. España. N ${ }^{\circ}$.7, Ago./ 2002.

MORALES, Jorge. Los objetivos específicos en interpretación (Para saber, sentir y hacer). Boletín de Interpretación. Asociación para la Interpretación del Patrimonio. España. $\mathrm{N}^{\circ} .4$, Ene./ 2001.

MOREIRA, Fernando João de Matos. O Turismo e os Museus nas Estratégias e nas Práticas de Desenvolvimento Territorial. (Dissertação) Lisboa: Universidade Lusófona de Humanidades e Tecnologias. 2008.

MORIN, Peter. Community Ecology. Massachusetts, USA: Blackwell Science, 1999.

MORLEY, Edna June. Como preservar os sítios arqueológicos brasileiros. In: Tenório, Maria Cristina (org.). Pré-História da Terra Brasilis. Rio de Janeiro: Editora UFRJ, 2000.

MOTA, Antônio; LADEIRAS, Ana e COSTA, Jorge. Contributos para um modelo de planeamento estratégico em turismo. Ayala Calvo, J.C. y grupo de investigación FEDRA. Conocimento, innovación y empreendedores: Camino al futuro. s/d. Disponível em: http://dialnet.unirioja.es/servlet/fichero articulo?codigo=2234680. Último acesso: fev./2012.

MOYSÉS, G. L. R. e MOORI, R. G. Coleta de dados para a pesquisa acadêmica: um estudo sobre a elaboração, a validação e a aplicação eletrônica de questionário. XXVII Encontro de Engenharia de Produção. A energia que move a produção: um diálogo sobre integração, projeto e sustentabilidade. Foz do Iguaçu, PR. Brasil, 2007.

NAI (National Association for Interpretation). Standards and Practices for Interpretive Planning. 2009. 
NETHERY, William. Things and Places, Hearts and Minds. Interpreting Heritage Interpretation in New South Wales. Disponível em: http://www.international.icomos.org/quebec2008/cd/toindex/77 pdf/77-gJ85112\%20.pdf. Último acesso: 03/2012.

NETO, Pedro Garcia. Paricatuba: Uma breve abordagem etnográfica do processo históricocultural. Revista de Ciências Humanas e Sociais da FSDB, Ano I, Vol. II, Julho-Dezembro, 2005. p.28-29. Disponível em: http://www.fsdb.edu.br/pdf/Il_eletronica.pdf. Último acesso: abril/ 2012

NEVES, Eduardo G. Amazônia Ano 1000. Revista National Geografic Brasil. Maio, 2010.

NEVES, Eduardo G. Levantamento Arqueológico da Área de Confluência dos Rios Negro e Solimões, Estado do Amazonas. Relatório de Atividades. MAE/ USP. Jun./ 1999 a Ago./ 2000.

NEVES, Eduardo G. Levantamento Arqueológico da Área de Confluência dos rios Negro e Solimões, Estado do Amazonas: Continuidade das Escavações, Análise da Composição Química e Montagem de um Sistema de Informações Geográficas. Relatório enviado à FAPESP, 2002 (não publicado).

NEVES, Eduardo G.; PETERSEN, James B.; BARTONE, Robert N. e SILVA, Carlos Augusto da. Historical and Socio-cultural origins of Amazonia Dark Earths. In: J. LEHMANN, et al. (eds.), Amazonian Dark Earths: Origin, Properties, Management. Netherlands: Kluwer Academic Publishers. 2003.

NIKNAMI, K. A. Archaeology and cultural Tourism Development in Iran. Journal of the Faculty of Letters and Human Sciences. Disponível em: http://journals.ut.ac.ir/page/downloadtlzsinLhz4U.artdl. Último acesso: abr./2010.

NSW Heritage Office. Interpreting Heritage Places and Items - Guidelines. Heritage Information Series. Australia, 2005.

Oficina de Réplicas. Endereço: http://www2.igc.usp.br/replicas. Último acesso: mar./2009.

OKAMOTO, Jun. Percepção Ambiental e Comportamento. São Paulo: Plêiade, 1996.

OLIVEIRA, Alexandre A. et al. Florestas sobre Areia: campinaranas e igapós. In: VARELLA, Drauzio (coord.). Florestas do Rio Negro. São Paulo: Cia. das Letras: UNIP, 2001.

ORDEN, Claudia de la. Una mirada al pasado para comprender nuestro presente. Boletín de Interpretación. Asociación para la Interpretación del Patrimônio. España. N ${ }^{\circ}$.8. Ene./ 2003.

PADRÓ WERNER, Jordi. La Interpretación: Un método dinámico para promover el uso social del patrimonio cultural y natural. Disponível em: http://www.terraincognita.org/ct/terra documentos2ct.htm (1 of 12), 2002. Último acesso: jun./ 2009.

PALLESTRINI, Luciana e MORAIS, José Luiz. Arqueologia Pré-Histórica Brasileira. Universidade de São Paulo, Museu Paulista. Fundo de Pesquisas. São Paulo, 1982.

PANOSSO NETTO, Alexandre e ANSARAH, Marilia G. dos Reis. Segmentação em turismo: panorama atual. In: PANOSSO NETTO, Alexandre e ANSARAH, Marilia G. dos Reis (Eds.). Segmentação do mercado turístico: estudos, produtos e perspectivas. Barueri, SP: Manole, 2009. 
PARDI, Maria Lucia Franco. Gestão de Patrimônio Arqueológico, Documentação e Política de Preservação. Dissertação (Mestrado). Goiânia, GO: Universidade Católica de Goiás, 2002.

PEDERSEN, Arthur. Managing Tourism at World Heritage Sites: a Practical Manual for World Heritage Site Managers. Paris: UNESCO World Heritage Centre. 2002.

PENA, S. D. J. , CARVALHO-SILVA, D. R., ALVESSILVA, J., PRADO, V. F. e SANTOS, F. R. Retrato molecular do Brasil. Ciência Hoje, 159:16-25, 2000.

PENNA, Belizário. A leprosaria de Paricatuba. Rio de Janeiro: Biblioteca Nacional, 1926.

PERES, Carlos e SCHNEIDER, Maurício. Subsidized agricultural resettlements as drivers of tropical deforestation. Biological Conservation (2011). Disponível em: http://www.doi:10.1016/i.biocon.2011.11.011. Último acesso: fev./2012.

PÉREZ, Xerardo Pereiro. Turismo Cultural. Uma visão antropológica. El Sauzal (Tenerife. España): ACA y PASOS, RTPC. 2009.

PESSOA, Alba Barbosa. Infância e trabalho: dimensões do trabalho infantil na cidade de Manaus, 1890/1920. (Dissertação). Manaus, AM: Universidade Federal do Amazonas, 2010.

PETERSEN, James, NEVES, Eduardo e HECKENBERGER, Michael. Gift from the past: Terra Preta and prehistoric Amerindian Occupation in Amazonia. In: McEWAN, Colin; BARRETO, Cristiana e NEVES, Eduardo (Eds.) Unknown Amazon: Culture in nature in ancient Brazil. London: The British Museum Press. 2001.

PIRES, Mário Jorge. Levantamento de atrativos históricos em turismo - uma proposta metodológica. In: LAGE, Beatriz H. e MILONE, Paulo C. (orgs.) Turismo: Teoria e Prática. São Paulo: Atlas, 2000.

PONTE, Antonio Carlos da. Aspectos penais da preservação do patrimônio histórico e cultural. Lex. Revista do Direito Brasileiro, Vol. 1, 2006.

PORTOCARRERO, R. A. C. A variabilidade espacial no sítio Osvaldo. Estudo de um assentamento da tradição barrancóide na Amazônia Central. (Dissertação) São Paulo: MAE/ USP, 2007.

PROUS, André. O Brasil antes dos brasileiros. A pré-história do nosso país. Rio de Janeiro: Jorge Zahar Ed., 2006.

RANZI, Alceu. Geoglifos: a descoberta e o potencial turístico. In: SCHAAN, Denise; RANZI, Alceu e BARBOSA, Antônia D. Geoglifos: paisagens da Amazônia Ocidental. Rio Branco: GKNORONHA, 2010.

RAPP PY-DANIEL, Anne. Arqueologia da Morte no sítio Hatahara durante a fase paredão. (Dissertação). São Paulo, SP: MAE/ USP, 2009.

RAPP PY-DANIEL, Anne; MORAES, Claide de Paula; NEVES, Eduardo G e SILVA, Leandro Camilo. Ocupações pré-ceramistas nos areais da Amazônia central. Revista do Museu de Arqueologia e Etnologia da Universidade de São Paulo. Anais da II Semana de Arqueologia. Suplemento 11, 2011.

REBELLATO, L. Interpretando a Variabilidade Cerâmica e as Assinaturas Químicas e Físicas do Solo no Sítio Arqueológico Hatahara. (Dissertação) São Paulo: MAE/ USP, 2007. 
REJOWISKI, Mirian e SOLHA, Karina T. Turismo em um cenário de mudanças. In: REJOWISKI, Mirian (org.) Turismo no Percurso do Tempo. São Paulo: Aleph, 2002.

RENFREW, Colin e BAHN, Paul. Archaeology: Theories, Methods and Practice. 4ed. London: Thames \& Hudson, 2004.

RIBEIRO, Edinelsa Macedo; MACHADO, Ana Lúcia Soares; OLIVEIRA, Elane Conceição de; NASCIMENTO, Elimar Pinheiro. Comunidades à margem da sustentabilidade: um olhar sobre o Polo Ecoturístico de Iranduba (AM). Revista Brasileira de Ecoturismo, São Paulo, Vol.5, N.1, jan./abr. 2012.

RIES, Gabriela. Um grande potencial do Brasil: ecoturismo, turismo arqueológico e cultural. Anais. XIII Congresso da SAB: arqueologia, patrimônio e turismo - Campo Grande, MS: Ed. Oeste, 2005.

ROOSEVELT, A. C., M. Lima da Costa, C. Lopes Machado, M. Michab, N. Mercier, H. Valladas, J. Feathers, W. Barnett, M. Imazio Da Silveira, A. Henderson, J. Sliva, B. Chernoff, D. S. Reese, J. A. Holman, N. Toth, K. Schick. Paleoindian cave dwellers in the Amazon: the peopling of the Americas. Science 272:373-384, 1996.

ROOSEVELT, Anna. O Povoamento das Américas: o Panorama Brasileiro. In: TENÓRIO, Maria Cristina. Pré-História da Terra Brasilis. Rio de Janeiro: Ed. UFRJ, 2000. p. 36-50.

ROSS, Glenn. Psicologia do Turismo (tradução Dinah Azevedo). São Paulo: Contexto, 2001. (Coleção Turismo Contexto)

RUIZ, Antonio Espinosa. La accesibilidad física e intelectual de todos tipos de público al patrimonio cultural (II). Boletín de Interpretación. Asociación para la Interpretación del Patrimônio. España. $\mathrm{N}^{\circ} .7$, Ago./ 2002.

SANTANA, Agustín. Patrimonio cultural y turismo: reflexiones y dudas de un anfitrión. Revista Ciencia y Mar, Nº.6: 37-41. 1998.

SANTOS, Luiz Antonio de Castro; FARIA, Lina e MENEZES, Ricardo Fernandes de. Contrapontos da história da hanseníase no Brasil: cenários de estigma e confinamento. $R$. Bras. Est. Pop., São Paulo, Vol. 25, n. 1, p. 167-190, jan./jun. 2008.

SCATAMACCHIA, Maria Cristina M. Turismo e Arqueologia. São Paulo: Aleph, 2005 (Coleção $A B C$ do Turismo).

SCHAAN, Denise. Arqueologia, Público e Comodificação da herança cultural: o caso da cultura Marajoara. Revista Arqueologia Pública, São Paulo, Nº.1: 19-30, 2006.

SCHAAN, Denise. Long-Term Human Induced Impacts on Marajó Island Landscapes, Amazon Estuary. Diversity 2010, 2, doi:10.3390/d2020182. Disponível em: www.mdpi.com/journal/diversity. Último acesso: fev./2012.

SCHAAN, Denise. Paisagens da Amazônia Ocidental. In: SCHAAN, Denise; RANZI, Alceu e BARBOSA, Antônia D. Geoglifos: paisagens da Amazônia Ocidental. Rio Branco: GKNORONHA, 2010.

SCHAAN, Denise; RANZI, Alceu e BARBOSA, Antônia D. Geoglifos: paisagens da Amazônia Ocidental. Rio Branco: GKNORONHA, 2010.

SCHMIDT, M. and HECKENBERGER, M. Amerindian Anthrosols: Amazonian Dark Earth Formation in the Upper Xingu. In: WOODS, Willian; TEIXEIRA, Wenceslau G.; LEHMANN, 
Johannes; STEINER, Christoph; WINKLERPRINS, A.M. e REBELLATO, L. (Eds.), Amazonian Dark Earths: Wim Sombroek's Vision. USA: Springer Science + Business Media B.V. 2009.

SCHMIDT, Morgan J. Paisagens Construídas na Amazônia: Feições Topográficas, uso do Espaço, e Formação de antrosolos (Terra Preta) em Assentamentos Pré-Históricos. Comunicação oral no MAE/USP em 28/05/2012.

SCHMITZ, Pedro Ignácio. A questão do Paleoíndio. In: TENÓRIO, Maria Cristina. Pré-História da Terra Brasilis. Rio de Janeiro: Ed. UFRJ, 2000. p. 55-59.

SCOVAZZI, Tullio. A definição de Patrimônio Cultural Intangível. In: CUREAU, Sandra; KISHI, Sandra A. S.; SOARES, Inês Virgínia P. e LAGE, Claudia Marcia F. (Coord.) Olha Multidisciplinar sobre a efetividade da proteção do patrimônio cultural. Belo Horizonte: Fórum, 2011.

SHUNNAQ, Mohammed; SCHWAB, William A. e REID, Margaret F. Community Development Using a Sustainable Tourism Strategy: a Case Study of the Jordan River Valley Touristway. International Jounal Tourism Research 10: 1-14 (2008). Disponível em: www.interscience.wiley.com. Último acesso: set./2011.

SILVA, Carlos Augusto da e PUGLIESE, Francisco Antônio. Arqueologia e Educação Patrimonial na comunidade de Paricatuba. Anais. XIII Congresso da SAB: arqueologia, patrimônio e turismo - Campo Grade, MS: Ed. Oeste, 2005.

SILVA, Elsa Peralta da. Património e identidade. Os desafios do turismo cultural. Antropológicas, $\mathrm{N}^{\circ} .4,2000$. Disponível em: http://ceaa.ufp.pt/turismo3.htm. Último acesso: jun./2011.

SILVA, Fabíola. A etnoarqueologia na Amazônia: contribuições e perspectivas Bol. Mus. Para. Emílio Goeldi. Ciências Humanas, Belém, Vol. 4, Nº 1, jan.- abr. 2009.

SILVA, Fernando Brasil da. A Psicologia aplicada ao Turismo e Hotelaria. 2ed. São Paulo: CenaUn, 2000.

SILVA, Glaubécia Teixeira da. Percepções Sócio-espaciais e de Turismo em Paricatuba Iranduba - Amazonas. (Dissertação) Manaus, AM: Universidade do Estado do Amazonas. 2008.

SILVA, Maria Domingas de Araújo. O turismo como indutor de desenvolvimento para a comunidade de Janauari - Município de Iranduba - Amazonas. (Trabalho de Conclusão de Curso) Manaus, AM: Escola Superior de Artes e Turismo. Universidade do Estado do Amazonas. 2007.

SILVEIRA, Maura Imazio e SCHAAN, Denise Pahl. A vida nos manguezais: a ocupação humana na Costa Atlântica Amazônica durante o Holoceno. In: PEREIRA, Edithe e GUAPINDAIA, Vera (Orgs.). Arqueologia Amazônica. Belém: MPEG; IPHAN; SECULT, 2010.

SIMÕES, Mário F. e MACHADO, Ana Lúcia. Pesquisas arqueológicas no lago de Silves (Amazonas). Revista de arqueologia, Vol.4, N.1: 49-82. Belém, 1897.

SOLHA, Karina T. Evolução do turismo no Brasil. In: REJOWISKI, Mirian (org.) Turismo no Percurso do Tempo. São Paulo: Aleph, 2002.

SOUSA, Maria Sueli Rodrigues de. O povo do Zabelê e o Parque Nacional da Serra da Capivara no Estado do Piauí - Tensões, Desafios e Riscos da Gestão Principiológica da Complexidade Constitucional. Tese (doutorado). Brasília: UNB, 2009. 
SOUZA, Marise Campos de. Uma visão da abrangência da Gestão Patrimonial. In: MORI, Vitor Hugo; SOUZA, Marise Campos de; BASTOS, Rossano Lopes e GALLO, Haroldo (Orgs.). Patrimônio: atualizando o debate. MinC, IPHAN. 2006.

STOEP, Gail. La interpretación es un instrumento para la gestión. Boletín de Interpretación. Asociación para la Interpretación del Patrimônio. España. Número 8. Enero de 2003.

SWARBROOKE, John e HORNER, Susan. O comportamento do consumidor no turismo. São Paulo: Aleph, 2002.

TAMANAHA, Eduardo Kazuo. A Tradição Policroma no Baixo e Médio rio Solimões. (Dissertação). São Paulo, SP: MAE/ USP, 2012.

THURLEY, Simon. Into the future. Our stategy for 2005-2010. In: Conservation Bulletin [English Heritage], 2005 (49).

TILDEN, Freeman. Interpreting Our Heritage. 4ed. USA: The University of North Carolina Press. 2007.

TRESSERRAS, Jordi Juan. El arqueoturismo o turismo arqueológico: un paso más para la valorización del patrimonio arqueológico. Boletín GC: Gestión Cultural № 9: Turismo Arqueológico, octubre de 2004.

UFAM. EPIA/RIMA Travessia Rio Negro por Ponte. 2007.

UNESCO. Convention for the Safeguarding of the Intangible Cultural Heritage. Paris, 17 October 2003.

UNWTO. Global Code of Ethics for Tourism, for Responsible Tourism. Disponível em: http://www.unwto.org/ethics/full_text/en/pdf/Codigo_Etico_Ing.pdf. Último acesso: mai./2012.

UPSTATE INSTITUTE at Colgate University. Symposium on Cultural and Heritage Tourism Working Together in Madison County. New York: April, 2010. Disponível em: http://upstate.colgate.edu/dialogue/culturaltourism.aspx. Último acesso: jan./2012.

VALECILLO, Zaida Garcia. Como acercar los bienes patrominiales a los ciudadanos? Educación Patrimonial, un campo emergente en la gestión del patrimônio cultural. Passos. Vol. 7. $\mathrm{N}^{\circ} .2$, pags 271-280. 2009.

VICENTINI, Alberto. As Florestas de Terra Firme. In: VARELLA, Drauzio (coord.). Florestas do Rio Negro. São Paulo: Cia. das Letras: UNIP, 2001.

WIDMER, Glória Maria. Turismo Arqueológico. In: PANOSSO NETTO, Alexandre e ANSARAH, Marilia G. dos Reis (Eds.). Segmentação do mercado turístico: estudos, produtos e perspectivas. Barueri, SP: Manole, 2009.

WORLD MONUMENTS FUND. Financing Cultural/Natural Heritage and Sustainable Development. Jonathan Calame (rapporteur). International Conference, May 28-31, 1996 - International Center of Croatian Universities. Dubrovnik, Croatia. September, 1996.

ZANETTINI, Paulo Eduardo. Arqueólogos de volta à metrópole. In: MORI, Vitor Hugo; SOUZA, Marise Campos de; BASTOS, Rossano Lopes e GALLO, Haroldo (Orgs.). Patrimônio: atualizando o debate. MinC, IPHAN. 2006.

ZANETTINI, Paulo. Qual o Futuro Desejamos para a Arqueologia no Brasil. Arqueologia em debate. Jornal da Sociedade de Arqueologia Brasileira, N.2, 2010. 
ZANETTINI, Paulo. Qual o futuro desejamos para a arqueologia no Brasil? Arqueologia em Debate. Jornal da Sociedade de Arqueologia Brasileira, Nº.2. Out./2010.

ZEIDEMANN, Vivian Karina. O Rio das Águas Negras. In: VARELLA, Drauzio (coord.). Florestas do Rio Negro. São Paulo: Cia. das Letras: UNIP, 2001. 
ANEXos 


\section{d CA BA

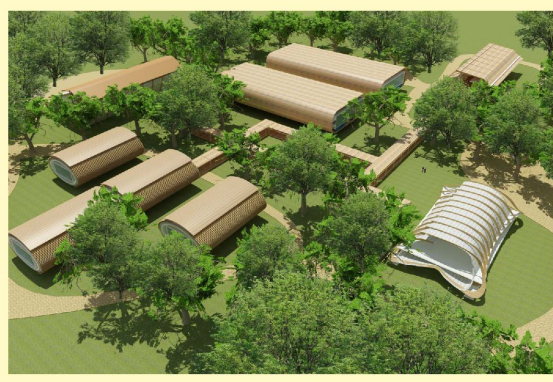

A Amazônia Ocidental tem um rico patrimônio arqueológico e poucas Instituições locais habilitadas para seu estudo. O Centro de Arqueologia do Bioma Amazônico (CABA) pretende contribuir para mudar esse quadro.

Localizado no municipio de Iranduba, às margens do rio Solimões, no Estado do Amazonas, o CABA será responsável pela guarda, curadoria, pesquisa e exposição de coleções arqueológicas obtidas na Amazônia Ocidental.

O CABA é resultado de uma parceria entre o CEAP Amazônia - Centro de Excelência Ambiental da Petrobras - e o Museu de Arqueologia e Etnologia da Universidade de São Paulo, MAE-USP. Inicialmente atenderá às demandas de pesquisas arqueológicas resultantes das iniciativas da Petrobras e de pesquisas básicas do MAE, mas deverá também atuar em parceria com outras Instituições.

Uma primeira iniciativa nesse sentido será a associação com a Universidade do Estado do Amazonas (UEA) para o desenvolvimento do Curso Superior de Tecnologia em Arqueologia. Com início previsto para 2009 , o curso contará com 30 vagas voltadas principalmente para alunos do interior do Estado.
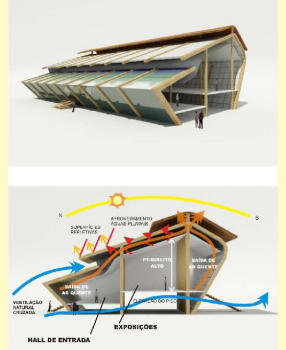

$=0$
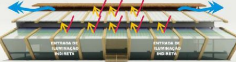

SALA DE EXPOSIÇÕES

RESERVA TÉCNICA
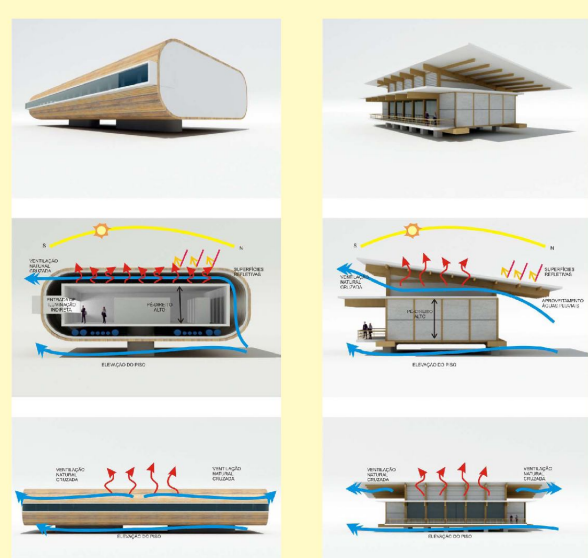

SALAS DE AULA
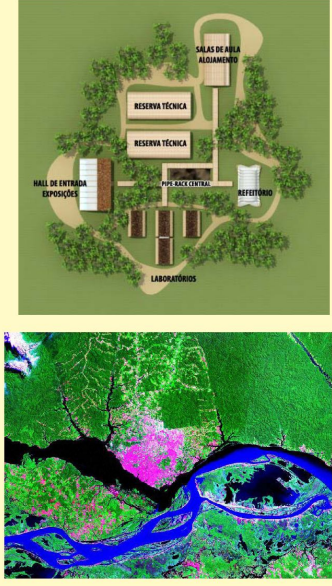

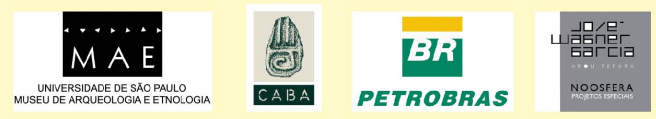




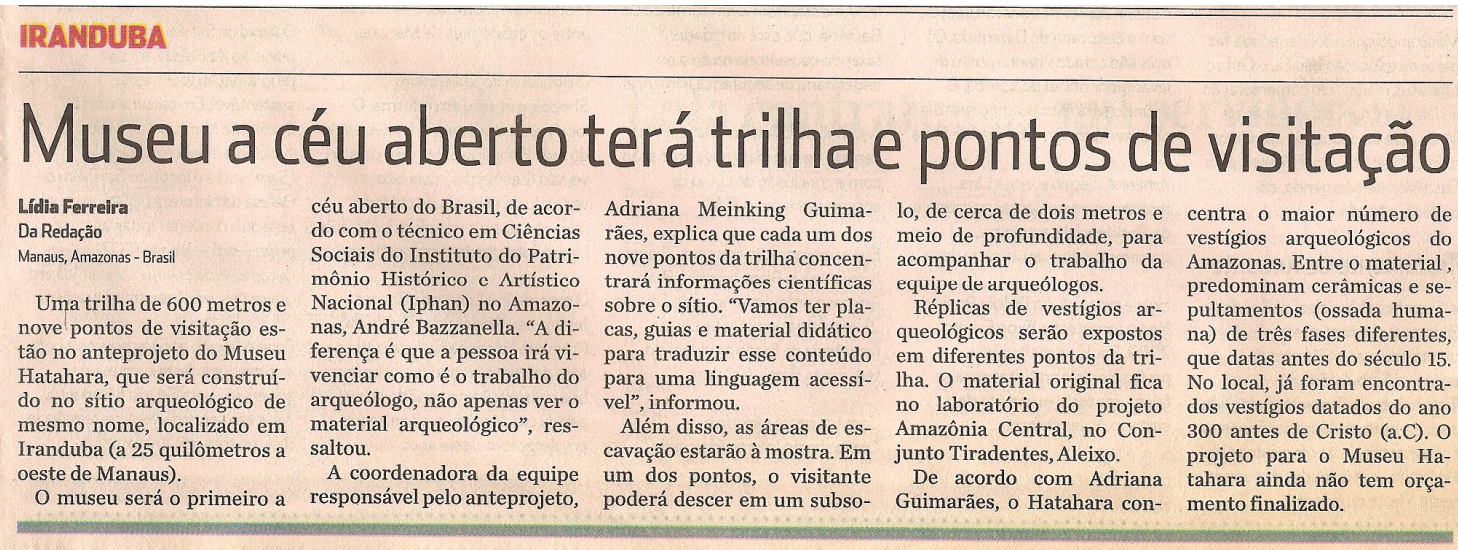

ANeXo 03 - RePortagem ‘A CRítICA’. 07 de OUTUBRo de 2009.

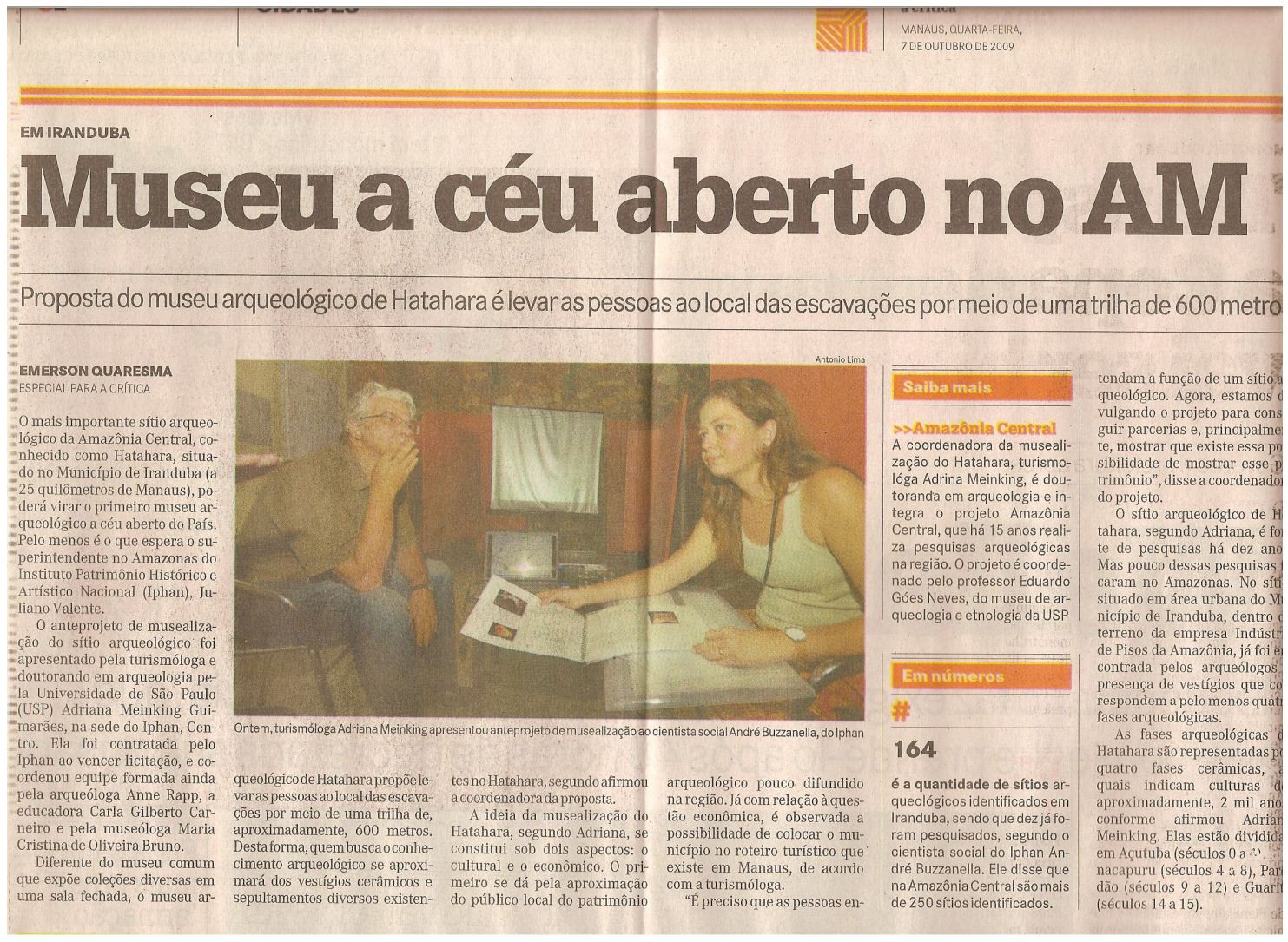


ANEXo 04 - RePortAgem ‘O GLOBO ONLINE’. 07 DE OUTUBRo de 2009.

\section{Sítio Hatahara, no Amazonas, poderá ser primeiro museu arqueológico a céu aberto do país. Plantão | Publicada em 07/10/2009 às 11h50m \\ Portal Amazônia, o Globo}

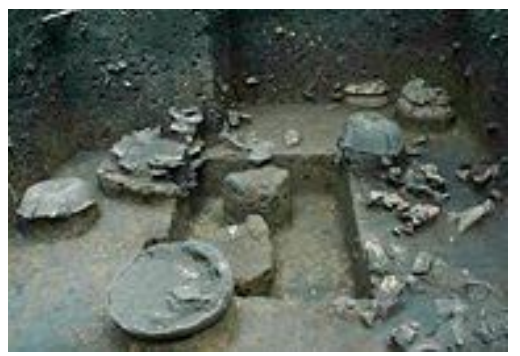

MANAUS - O sítio arqueológico Hatahara, situado no município de Iranduba, a 25 quilômetros de Manaus, poderá virar o primeiro museu arqueológico a céu aberto do País. O projeto foi apresentado pela turismóloga e doutoranda em arqueologia pela Universidade de São Paulo Adriana Meinking Guimarães, na sede do Instituto Patrimônio Histórico e Artístico Nacional (Iphan).

De acordo com o superintendente no Amazonas do Iphan, Juliano Valente, diferentemente do museu comum, que expõe coleções diversas em uma sala fechada, o museu de Hatahara propõe levar as pessoas ao local das escavações por meio de uma trilha de, aproximadamente, 600 metros.

No sítio, situado em área urbana de Iranduba, dentro do terreno da empresa Indústria de Pisos da Amazônia, os arqueólogos encontraram a presença de vestígios que correspondem a pelo menos quatro fases arqueológicas. Iranduba fica na confluência dos rios Negro e Solimões.

No local já foram encontradas urnas funerárias, vasos e utensílios de cerâmica. Muitos têm apliques em formas de cabeças de pessoas ou animais, as chamadas 'caretinhas'. Em 2006 foi achado o primeiro esqueleto inteiro de um índio enterrado entre os séculos 8 e 12 d.C. O corpo estava na área identificada como cemitério indígena, a

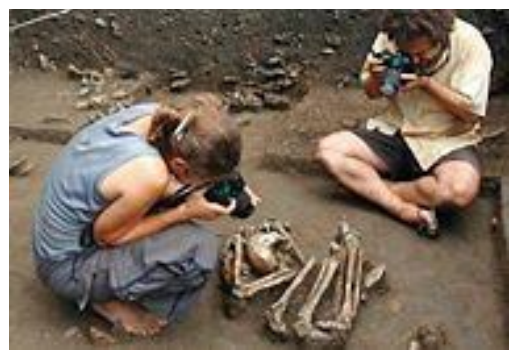
apenas um metro de profundidade.

Segundo dados do Centro de Arqueologia dos Biomas da Amazônia, a bacia Amazônica é ocupada há mais de 10 mil anos. Até o século XV, era densamente ocupada por diferentes povos indígenas, cada um deles com modo de vida diferente - algumas tribos eram nômades; outras totalmente hierarquizadas.

O mapeamento dos sítios arqueológicos no Amazonas começou em 1995 com o projeto Amazônia Central, criado pelos pesquisadores Michael Heckenberger (Departamento de Antropologia, Universidade da Florida), James Petersen (Departamento de Antropologia, Universidade de Vermont) e Eduardo Góes Neves (Museu de Arqueologia e Etnologia, Universidade de São Paulo). O projeto engloba cerca de 150 sítios arqueológicos na região. 
AneXo 05 - Mapa Central do Janauarizinho. Elaboração: Sr. Milton.

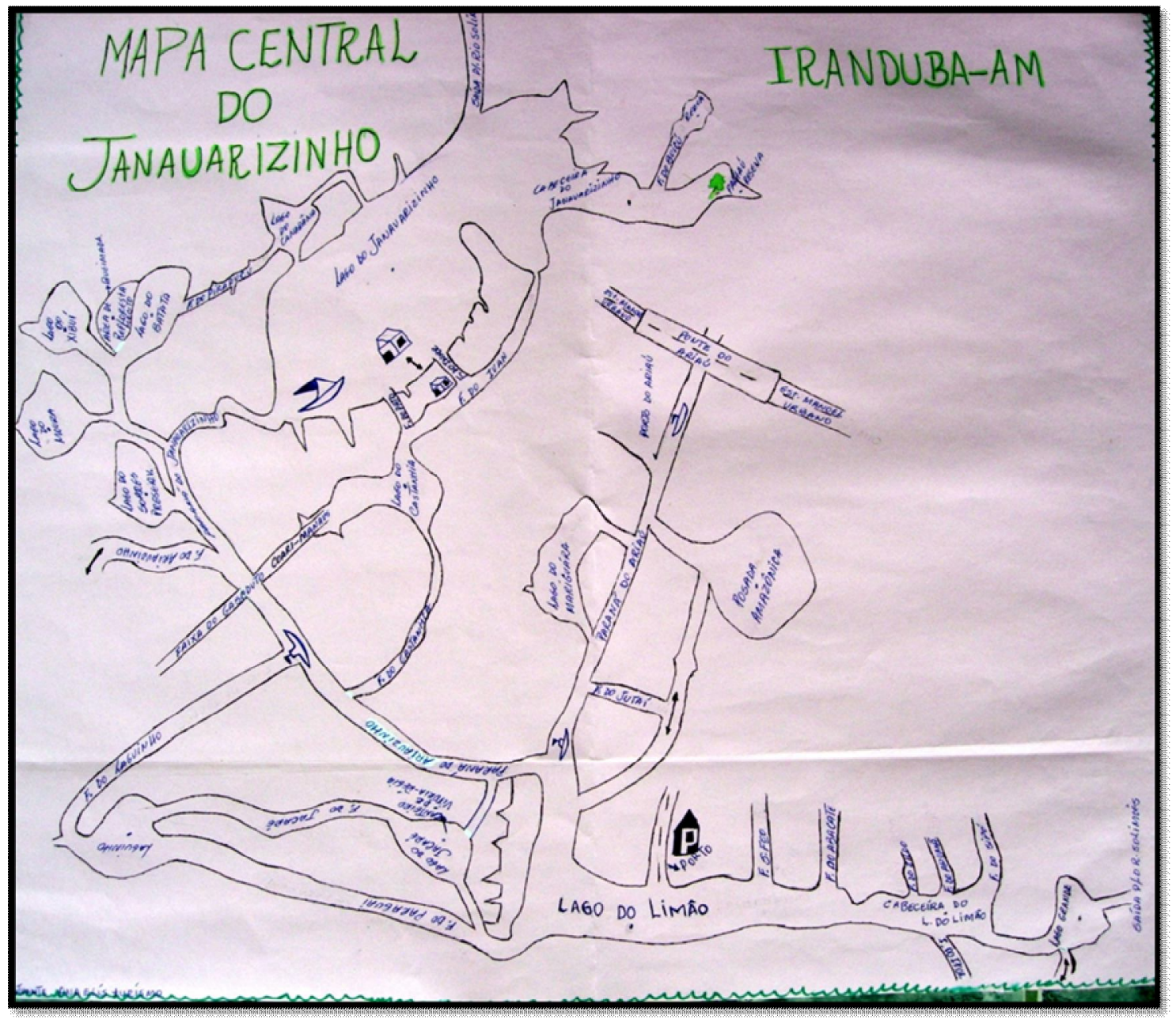


ANeXo 06 - Mapa Lago do Limão. ElaboRAÇÃo: Sr. Milton.

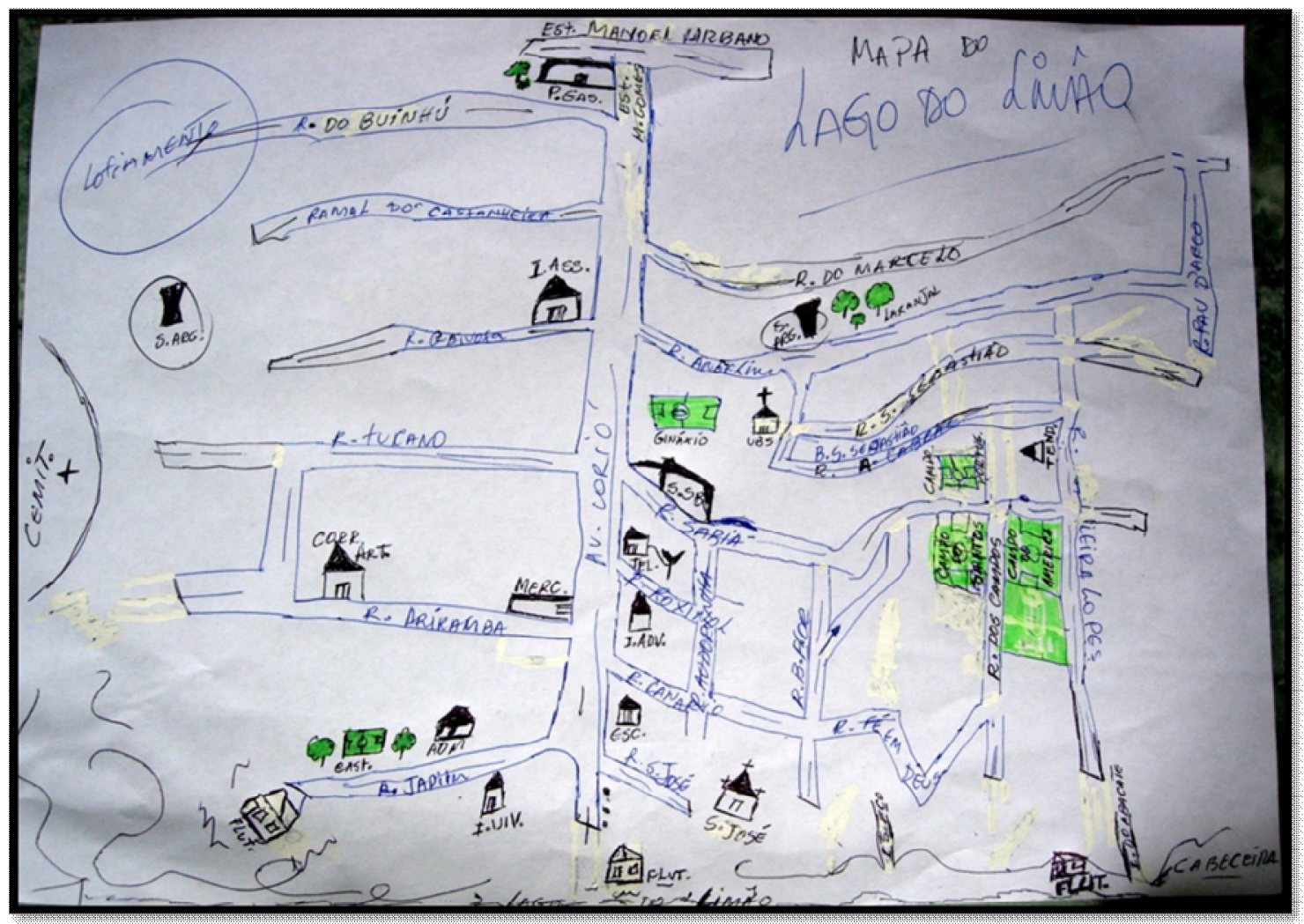


ANEXo 07 - Relatório Gisele Felipe.

- $\quad$ Treinamento da Equipe de Campo e Visita dos Turistas

Realização: 12. 07.10

Devido à presença de quatro turistas hospedados na Pousada Aldeia dos Lagos, e a sua vontade de conhecer os sítios arqueológicos do Pontão, o treinamento dos turistas dos alunos em campo foi feito sem a realização do curso para os membros da ASPAC.

Sinteticamente foi dada primeiramente a explicação sobre o projeto desenvolvido por Adriana Guimarães, comentando sobre o objetivo específico da criação de roteiros voltados a segmentação do turismo arqueológico e o seu detalhamento, ou seja, as atividades que iriam se processar para que o mesmo fosse atingido.

Em seguida, abordou-se sobre o que de fato se constituiu o turismo e as suas especificidades segundo a OMT. Compreendendo que o turismo é segmentado assim como a Arqueologia, foi enfatizado o segmento turismo arqueológico comentando no que consiste o termo, as suas modalidades e uma noção geral das bases para ser processado de forma sustentável.

A partir disso, foi dado um panorama geral do arqueoturismo no Brasil, colocando o Parna Serra da Capivara como um modelo a ser seguido. Foi mostrado que os sítios arqueológicos do Brasil cada vez mais estão sendo musealizados ou os vestígios estão sendo expostos em Centros Cultura e Museus espalhados pelo país.

Após esse primeiro momento, foi colocada a proposta de visitação planejada anteriormente e a maneira como os alunos deveriam se portar frente aos turistas, enfatizando a educação, a presteza de informações, a sensibilização para a causa arqueológica e a necessidade de preservação dos artefatos existentes nos sítios. É importante ressaltar que a Comunidade do Pontão não estava sabendo dessa visitação dos turistas sendo, portanto, necessário que todos os alunos esclarecessem a comunidade sobre o que de fato iria acontecer no sítio a desse dia, mostrando que era apenas um teste para se verificar a viabilidade e potencialidade em se implantar um roteiro de cunho arqueológico que pudesse ser explorado dentro da comunidade futuramente. 
Após a discussão com os alunos conversei com o Giovanni (Secretário da Comunidade) e com a Professora Eurídice, com o objetivo de ter a autorização para o desenvolvimento das atividades de roteiro propostas, culminando no consentimento e da colocação de que a comunidade tinha interesse em implantar o turismo na localidade.

Por fim, foi repassado o questionário para a verificação do treinamento com os alunos arqueologia. Ao todo foram aplicados 14 questionários, valendo observar que a última questão não foi respondida já que o percurso realizado pelos turistas foi proposto na hora de visitação.

É interessante colocar que a duração do roteiro guiado pela professora Helena foi de 2 horas e consistiu na visita a três unidades de escavação, com explicações dadas pelos alunos sobre - motivo das pesquisas na localidade, as hipóteses criadas para a área de estudo, o entendimento da cronologia de ocupação através da estratigrafia, a importância em se preservar os sítios arqueológicos, entre outros.

Segundo um dos turistas em conversa informal com a professora Helena, as escavações realizadas no Pontão não atrairiam ou satisfariam as expectativas de outros turistas que senão eles, já que os mesmos tinham interesse nesse tipo de atrativo.

O questionário (4 ao todo) foi aplicado com todos eles no inicio e no final da visita. É importante destacar que não foi cobrado ingresso para a visitação, bem como foi descartada a possibilidade de participação dos turistas nas escavações (roteiro proposto A- "Um dia de Arqueólogo").

O manual de boas práticas arqueoturísticas foi mostrado para os turistas na noite anterior a visitação pela professora Helena. Não foi feito o treinamento dos mesmos antes da visitação, mas sim durante o percurso através de comentários da própria professora ou do Mauricio.

Destaca-se também a visitação ao sítio Pontão pelos alunos das escolas de Silves ou de Comunidades, através da proposta de educação patrimonial desenvolvida pela Professora Tereza Parente. Estima-se que tenham visitado pelo menos 60 alunos de várias faixas etárias, culminando na elaboração de diversos registros em forma de desenhos ou documentos sobre a localidade. (A professora Tereza Parente pode dar maiores detalhes). 
- $\quad$ Curso de Turismo e Arqueologia

Com relação ao curso proposto, não foi possível realizá-lo apesar de várias tentativas da equipe. Os obstáculos foram vários: a ausência de no local interessadas em participar, em especial da Comunidade do Pontão e do São João (embora nós tenhamos mudado para a Escola 5 de Setembro, com o objetivo de inserir a comunidade de forma mais efetiva no curso); o fato dos guias de turismo da cidade estarem atuando na profissão por ser período de alta estação; a falta de interesse da comunidade, dos guias e dos membros da ASPAC, embora o convite e a divulgação tenham sido feitos, entre outros.

- Marcação de Percurso

Conforme já comentado anteriormente, não foi feita a marcação de percurso.

- Divulgação

A divulgação do curso foi promovida de modo informal através de propaganda boca a boca e não com os cartazes enviados para a distribuição estratégica em pontos chave da cidade.

\section{- $\quad$ Observações}

É importante destacar algumas observações obtidas em conversas informais pela comunidade do Pontão. Segundo os moradores, o turismo já era desenvolvido há alguns anos na comunidade do Pontão, embora não gerasse renda para os mesmos. Os turistas vinham visitar principalmente, as plantas, as frutas e o modo de vida daquele lugar, não pagando nenhum tipo de "ingresso" que beneficiasse a comunidade e sim, trazendo brinquedos e doces para as crianças. A presença dos turistas não incomodava o dia-a-dia dos moradores, muito pelo contrário, muitos gostavam da presença de outras pessoas já que podiam tocar experiências e conversar.

As pessoas chaves para obter qualquer tipo de informação sobre a questão do turismo na comunidade são o Sr. Antonio Barros e Sra. Lorivalda Neves. Segundo informações obtidas com eles, existem diversos atrativos dentro da comunidade que poderiam ser mostrados aos visitantes a partir de um turismo planejado: a casa de farinha; as plantas e frutas da 
localidade; o modo de pescar; o cotidiano dos comunitários; a roça; a feitura de cerâmicas; o processo de torrar café, entre outros.

No Pontão existem dois momentos onde a visitação é mais intensa: na festa religiosa da Padroeira da comunidade Nossa Senhora do Bom Parto, em dezembro e os jogos de futebol realizados todos os domingos.

Particularmente, acredito que o desenvolvimento do turismo ou especificamente do segmento arqueológico dentro da Comunidade do Pontão, poderia atrapalhar o modo de vida dos moradores e traria problemas diversos ainda que seja executado de forma planejada. O que poderia ser feito é estimular a visitação por membros de outras comunidades locais a partir dos eventos e das festas que já existem ou incentivar outras atividades paralelas que movimentem o dinheiro na localidade, tais como a venda de cerâmica, de lanches, entre outros. 